\title{
The Joseph Story \\ between Egypt and Israel
}

\author{
Edited by \\ KONRAD SCHMID, \\ THOMAS RÖMER, \\ and AXEL BÜHLER
}

Archaeology and Bible

5

Mohr Siebeck 


\title{
Archaeology and Bible
}

\author{
Edited by \\ Israel Finkelstein (Tel Aviv) • Deirdre Fulton (Waco, TX) \\ Oded Lipschits (Tel Aviv) · Christophe Nihan (Lausanne) \\ Thomas Römer (Lausanne) · Konrad Schmid (Zürich)
}

5

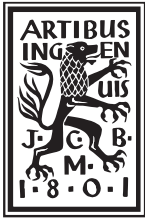





\section{The Joseph Story between Egypt and Israel}

Edited by

Thomas Römer, Konrad Schmid, and Axel Bühler 
Thomas Römer, born 1955; professor and chair of the Collège de France and Professor emeritus of the University of Lausanne.

orcid.org/0000-0002-6490-7678

Konrad Schmid, born 1965; professor of Old Testament and Ancient Judaism at the Faculty of Theology at the University of Zürich, Switzerland.

orcid.org/0000-0002-8968-2604

Axel Bühler, born 1992; currently PhD student at the University of Geneva and research assistant at the University of Geneva and the Collège de France.

orcid.org/0000-0001-5062-8806

The prepress production of this book and the eBook were published with the support of the Swiss National Science Foundation.

ISBN 978-3-16-160153-8/ eISBN 978-3-16-160154-5

DOI 10.1628/978-3-16-160154-5

ISSN 2698-4520 / eISSN 2698-4539 (Archaeology and Bible)

The Deutsche Nationalbibliothek lists this publication in the Deutsche Nationalbibliographie; detailed bibliographic data are available at $h t t p: / / d n b . d n b . d e$.

(C) 2021 Mohr Siebeck Tübingen, Germany. www.mohrsiebeck.com

This work is licensed under the license "Attribution-NonCommercial-NoDerivatives 4.0 International" (CC BY-NC-ND 4.0). A complete Version of the license text can be found at: https:// creativecommons.org/licenses/by-nc-nd/4.0/.

The book was typeset by Martin Fischer in Tübingen using Minion typeface, printed on nonaging paper by Laupp \& Göbel in Gomaringen, and bound by Buchbinderei Nädele in Nehren. Published by Mohr Siebeck Tübingen, Germany. www.mohrsiebeck.com

Printed in Germany. 


\section{Table of Contents}

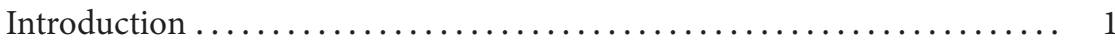

Franziska Ede

The Joseph Story: Diaspora Novella - Patriarchal Story -

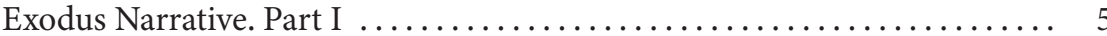

Reinhard Kratz

The Joseph Story: Diaspora Novella - Patriarchal Story -

Exodus Narrative. Part II: Historical Reflections . . . . . . . . . . . . . 23

Thomas Römer

How "Persian" or "Hellenistic" is the Joseph Narrative? ............. 35

Lauren Monroe

Stripping off the Robe. New Light on "Joseph the Hebrew"

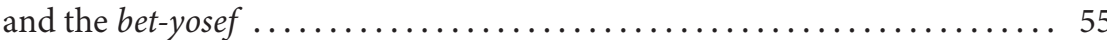

Samuel Arnet

Aspects of Jewish Identity in the Joseph Story $\ldots \ldots \ldots \ldots \ldots \ldots \ldots \ldots \ldots$

Safwat Marzouk

Forced Migration and Reconciliation in the Joseph Narrative ......... 85

Konrad Schmid

Sapiential Anthropology in the Joseph Story $\ldots \ldots \ldots \ldots \ldots \ldots \ldots \ldots \ldots . \ldots 103$

Camille Guerin

The Joseph Story from an Egyptological Perspective

Bernd U. Schipper

Joseph in Egypt. A Critical Evaluation of the Classical Parallels and a New Interpretation 


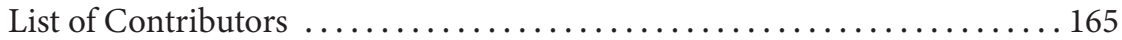

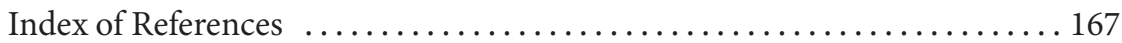

Index of Modern Authors ................................. 173

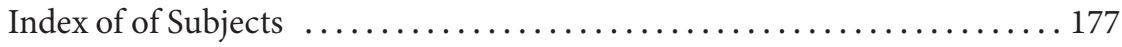




\section{Introduction}

In the context of the Pentateuch, the Joseph story is an astonishing narration. At first glance one can simply read it as a transition narrative that explains why Jacob and his family came to Egypt. In this regard, the story seems necessary for the book of Exodus, which starts by saying that the Israelites/Hebrews in Egypt had become a huge people. However, if one looks at other texts of the Hebrew Bible, there is no mention of the Joseph story; instead, the arrival of the Israelites is said to be the result of the decision of a "father" or of "fathers" to go down do Egypt (Deut 26:5-9; Num 20:15; cf. also Josh 24:4 and 1Sam 12:8). Indeed, there are very few references to Joseph at all in the whole Hebrew Bible. Outside Genesis 37-50, only Exod 13:19 and Josh 24:32 relate to the transport and burial of Joseph's bones in the land of Ephraim (pursuing Joseph's order given in Gen 50:25). And Psalm 105 is the only other text that alludes to Joseph in Egypt, though it does so quite differently from Genesis 37-50. This psalm is often considered to be one of the Psalter's latest texts, dating to the Persian or even Hellenistic period. ${ }^{1}$ Apparently, the Joseph story is not necessary for explaining why the Israelites found themselves in Egypt.

The question therefore arises: Why was this story written, when, and for what audience?

Here another paradox appears. Attentive readers of the book of Genesis will notice differences between the narrative about Joseph and the ones about the patriarchs in Genesis 12-36.

Whereas the stories about Abraham, Isaac, Jacob, and their wives are patchworks of a sort that combine previously independent narratives or cycles, the narrative about Joseph and his brothers is a straightforward story and cannot be interpreted as a combination of former independent units. Contrary to the Patriarchal narratives, the Joseph story does not contain any cultic etiology; whereas Abraham, Isaac, and Jacob receive divine speeches telling them what to do or informing them about future events, Joseph never has direct communication with God. The Joseph story clearly has its own style and plot. Gerhard von Rad was among the first to underline the literary character of the Joseph story and its wisdom flair in contrast to the patriarchal and exodus narratives. He praised the literary artistry of the Joseph story, but postulated a

\footnotetext{
${ }^{1}$ Some scholars think that the allusion of a young man coming out of prison in Qoh 4:13-16 may allude to the Joseph story. If this is the case, this nevertheless dates not further back than the Hellenistic period.
} 
J-version and an E-version that later redactors would have combined - a conclusion that seems forced into a prior theory. ${ }^{2}$ Yet still today, the separation of the Joseph story into a Yahwistic and an Elohistic version has some supporters. ${ }^{3}$ Nevertheless, no one has succeeded in reconstructing two coherent, independent narratives. ${ }^{4}$ The question of the literary unity of the story is open to discussion.

There are indeed several observations that indicate the need for a diachronic reconstruction of the Joseph story. But how can we reconstruct the original story, its date, and historical setting? If the Joseph narrative was not intended from the outset to conclude the patriarchal history or to provide a transition from the time of the ancestors into the Egyptian oppression and exodus, what was its intention? How much can Egyptology (archaeology, history, epigraphy, iconography) help us decide whether or not the author of the (original) Joseph story lived in Egypt? What would be a fitting date for the Joseph narrative? Many dates have been suggested for the first version of Genesis 37-50, which range from the beginning of the first millennium BCE (or even earlier) until the Hellenistic Period. Is the socalled Priestly document $(\mathrm{P})$ a terminus ad quem? Does $\mathrm{P}$ really know and presuppose the Joseph story?

These questions are discussed in this volume, which results from a workshop held in Lausanne on June $15^{\text {th }}-16^{\text {th }}, 2018$ as part of the Synergia project, "The History of the Pentateuch: Combining Literary and Archaeological Approaches," funded by the Swiss National Science Foundation. The event brought together Egyptologists, archaeologists, specialists in ancient history, and biblical scholars. Cumulatively, it represents the state of the art in historical research about the Joseph narrative.

Several contributions are devoted to the diachronic analysis of Genesis 37-50. Franziska Ede and Reinhard Kratz investigate the development of the Joseph Story between the patriarchal narratives and the Exodus story. Ede argues that the Joseph story initially represented a continuation of the patriarchal narratives (Genesis $37-45^{\star}$ ), to which it is connected through multiple catchword links. It can be understood as a diaspora novella that was transformed by later hands into

${ }^{2}$ G. von RAD, “Josephsgeschichte und ältere Chokmah,” in Congress Volume. Copenhagen 1953 (VTSup 1; Leiden: Brill, 1953), 120-127; see also IDEM, Das erste Buch Mose. Genesis (ATD 2-4; 9th ed. Göttingen: Vandenhoeck \& Ruprecht, 1972), 283-284.

${ }^{3}$ See for instance L. Ruppert, "Zur neueren Diskussion um die Joseferzählung in der Genesis," BZ.NF 33 (1989), 92-97; J.S. BADEN, The Composition of the Pentateuch: Renewing the Documentary Hypothesis (ABRL; New Haven, CT: Yale University Press, 2012), 34-44. See also H. Seebass, Genesis III. Josephsgeschichte (37,1-50,26) (Neukirchen-Vluyn: Neukirchner Verlag, 2000), who is much more cautious than some of his colleagues. He emphasizes that the Joseph story is "wegen ihrer formalen Geschlossenheit im Pentateuch singulär" (6) and admits an important post-priestly redaction (210-211).

${ }^{4}$ Despite the statement of B. J. Schwartz, "How the Compiler of the Pentateuch Worked: The Composition of Genesis 37," in The Book of Genesis. Composition, Reception, and Interpretation (ed. C.A. Evans et al.; VTSup 152; FIOTL 6; Leiden: Brill, 2012), 263-278. 
the narrative link between the patriarchal narratives and the exodus-conquestnarrative. Kratz shares the theory that we should read the older version of the Joseph story in Genesis 37-45 as a literary reflection on the Samarian-Judean diaspora in Egypt. Even if the classification as a "diaspora novella" does not fit the entire Joseph story, it is apt for Genesis 39-41 (and 47), allowing a date of the original Joseph story in the Persian or Hellenistic period. One can even understand the story as a refutation of the editors of the book of Jeremiah (Jeremiah 43-44), who reject and condemn the Egyptian diaspora. This point is also made by Safwat Marzouk (see below).

The issue of dating the Joseph story is also addressed by Thomas Römer. He agrees with Kratz and other contributors in this volume about characterizing the Joseph story as a diaspora novella, and about a Persian period context for the original Joseph narrative. But Römer finds several indications for a revision of the story in the Ptolemaic period, such as Joseph's second dream, Joseph's departure from Hebron, Pharaoh's birthday and dreams, and Joseph's invention of capitalism. These texts reflect the ideological and economic context of the Ptolemaic period.

Another approach is taken by Lauren Monroe, who wants to understand the Joseph story together with references to Joseph outside of the Hexateuch. She suggests that the association of the figure of Joseph with the bet-yosef, and the importance of the bet-yosef in pre- and early monarchic Israel, can explain the incorporation of Joseph into the family of Jacob as part of the process of constructing tribal Israel. Although diaspora interests did shape the canonical Joseph story, she argues that beneath the surface of this literary masterpiece lies "Joseph the Hebrew," the ancestor of a political entity that appears to have held a position of dominance in the central highlands of Canaan in the pre- and early monarchic period.

The Joseph story's ideology and its construction of the addressees' identity is analysed in several contributions. Samuel Arnet locates the ideology of the Joseph story in the context of post-exilic discourses about "Jewish" identity. Through examples of mixed marriages, divination, the presentation of the Egyptian king, and the naming of individuals, he shows that the Joseph story differs from deuteronomistic discourses as well as from those that can be detected in the books of Ezra and Nehemiah. Arnet's investigation shows that the construction of identity in the post-exilic period was complex; the position of some communities, such as the one behind the Joseph story, was apparently more "open" than the ideology of other groups.

Safwat Marzouk deals with the link between forced migration and reconciliation. He understands the Joseph story as a narrative that addressed the needs of a diaspora community - and one of those needs had to do with healing the fractured exiled community which had suffered from both external and internal causes of its forced migration. Joseph is a model for the diaspora community, 
and he is able to embrace his liminal space, and to maintain his hybrid identity as both a Hebrew and an Egyptian.

Konrad Schmid discusses the anthropology of the Joseph story by focussing on Joseph's second dream. This second dream is disturbing because of its imagery, since the scene where heavenly bodies venerate a human being clearly has blasphemous overtones. The non-fulfilment of this second dream indicates that the Joseph story does not portray a perfect Joseph, on the one hand, and totally negative brothers, on the other. One may therefore understand the Joseph story as combining an ethical and practical concept of wisdom with inspired wisdom, presenting the former as presupposing the latter.

Two contributions deal with the Joseph story from an egyptological perspective. Camille Guérin analyzes commercial, trade, and agricultural allusion in the Joseph story, as well as rites, customs and beliefs (like Joseph's embalming) and lexicographic features. She concludes that the Egyptian elements in the Joseph story help to date the narrative more precisely and can provide some information about its historical context. The egyptological evidence seems to correspond to Egypt during the Persian or even Hellenistic period.

Bernd Schipper confirms that the Egyptian evidence in the Joseph story points to the Neo-Babylonian and Persian period. The Joseph story should be understood above all in parallel to the Ahiqar tradition and the so-called Famine Stela that stands within an inner-Egyptian tradition, as shown by the papyrus pBerlin 23071, which bears a hieratic text datable to the Persian Period (fifth or fourth century вСЕ) on its verso. This text contains all the motifs of the Famine Stela that can be related to the biblical Joseph story.

This volume offers an overview of the current discussion on the origins, composition, and historical contexts behind the Joseph narrative. There is a tendency to date the story (or its original version) to the Persian period, but divergent voices do appear in this volume. Readers can reflect on possible convergences as well as divergences. The volume also shows that scholarly discussion about the historical location of the Joseph story requires bringing together Egyptologists and biblical scholars.

We thank Nina Jaillet and Phillip Lasater for their help in preparing the manuscript, the Swiss National Science Foundation for its support to make this work available via open access, and Mohr Siebeck for the production of this book. 


\title{
The Joseph Story: Diaspora Novella - Patriarchal Story - Exodus Narrative
}

\section{Part I}

\author{
Franziska Ede
}

The Joseph story represents both a part of the ancestral narratives and the narrative bridge between Genesis and Exodus. Joseph, first-born of Rachel and Jacob, continues the genealogical lineage of the patriarchs. Joseph, tribe of Israel, prepares the way for the exodus from Egypt. While this dual function is undeniable within the Masoretic text as it has come down to us, the original scope and function of the Joseph story have been highly disputed in recent Pentateuchal criticism. ${ }^{1}$

In analysis of select passages that have long been subject to controversy, this article will attempt to tackle both aspects. One crucial passage in this respect is Gen 37, as it constitutes the interface towards the ancestral narratives and sets the scene for the subsequent context. ${ }^{2}$ In consideration of pivotal aspects from Gen 37, I will first investigate the nature of the relation between the Joseph story and the preceding literary context, and will then inquire into the literary scope foreshadowed by ch. 37. The latter, of course, has implications for the question of when and how the Joseph story became the narrative link between the ancestral narratives and the exodus-conquest narrative.

\section{The Joseph Story and Its Relation to the Preceding Literary Context}

I will commence with a look at the double incentive for fraternal hatred in Gen 37 that has often given rise to the assumption of two independent sources. ${ }^{3}$ As any

\footnotetext{
${ }^{1}$ For an overview regarding current issues within Pentateuchal criticism cf. R. G. KRATZ, "The Analysis of the Pentateuch: An Attempt to Overcome Barriers of Thinking," ZAW 128 (2016), 529-561.

${ }^{2}$ For the relevance of Gen 37 with regard to an analysis of the Joseph story cf. H. DonNER, Die literarische Gestalt der Josephsgeschichte (SHAW.PH 2; Heidelberg: Universitätsverlag Winter, 1976).

${ }^{3}$ Cf. A. Dillmann, Genesis, (Leipzig: S. Hirzel, 1882), 372; H. Holzinger, Genesis, (KHC; Tübingen: Mohr Siebeck, 1898), 224, or H. Gunkel, Genesis, (4th ed.; HKAT I/1; Göttingen:
} 
decision regarding the original beginning of the Joseph story may influence the nature of its relation to the ancestral narratives, I will first clarify the interrelation between the passages on paternal preference and dreams.

The passage on paternal preference commences in Gen 37:3 and mentions a man called Israel, who is the father of multiple sons, one of whom, Joseph, he loves more than the others. Joseph's brothers perceive this imbalance and start to hate him. The motif of hatred is the necessary means to change scenery: Because of their hatred, the brothers sell Joseph to Egypt. The ultimate cause for this circumstance is the father, Israel, who preferred one son over the others.

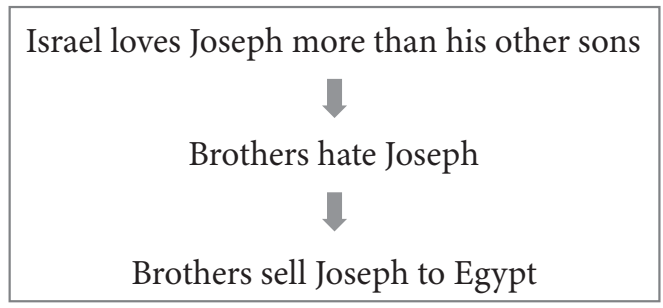

While Joseph thus remains a passive agent within v. 3-4, he contributes actively to an increase in hatred in v. 5-9. The relation between both passages may be unfolded as follows: v. 3 describes the familial constellation from the father's perspective, before v. 4 changes into the perspective of the brothers. They realize their father's greater love for Joseph and counteract it with their own hatred. V. 5-8 continue this horizontal perspective and focus on the fraternal conflict. This conflict is increased by Joseph himself, as he reveals the content of his dreams to his brothers. ${ }^{4}$ Both the fraternal perspective and the increase in hatred are, perhaps, easiest explained by the assumption that v. 5-9 know v. 3-4. Irrespective of any diachronic considerations v. 3-4 would then represent the oldest introduction to the Joseph story and as such could constitute a possible literary seam between the Joseph story and ancestral narratives. In the following I will verify this possibility by investigating discrete aspects from v. 3-4.

Gen 37:3-5

3יוישראל אהב את־יוסף מכל־בניו כי־בן־זקנים הוא לו ועשה לו כתנת פסים:4 ויראו אחיו כי־אתו אהב

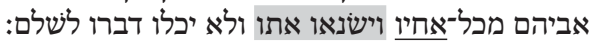

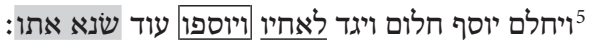

\footnotetext{
Vandenhoeck \& Ruprecht, 1917), 402; differently J. Wellhausen, Die Composition des Hexateuch (4th ed.; Berlin: Reimer, 1963), 54, who attributes V. 2b-11 to E.

${ }^{4}$ Cf. C. Levin, Der Jahwist (FRLANT 157; Göttingen: Vandenhoeck \& Ruprecht, 1993), 267-271.
} 


\subsection{Joseph, Son of Israel}

A first possible overlap with the ancestral narratives is the reference to Israel, who fathered a son named Joseph. While no mention of this exact familial constellation is attested within the ancestral narratives, Gen 29-30 provide a list of children born to Jacob, who is later renamed Israel by the deity. The change of name in Gen 32:29 equates the person Jacob with the national-political entity Israel and transfers the family history onto a meta-level that recounts the emergence of a people. ${ }^{5}$ Within the ancestral narratives this legend surrounding the emergence of Israel is created indirectly through the change of name and unfolded narratively through the stories of the patriarch and his god Yhwh. Since the authors of Gen 37:3-4 quite naturally refer to Joseph as son of Israel, the narrative introduced by these verses should best be read against the backdrop of the stories surrounding Jacob, who became Israel. ${ }^{6}$

Gen 32:29

29 ויאמר לא יעקב יאמר עוד שמך כי אם־ישראל כי־שרית עם־אלהים ועם־אנשים ותוכל:

Gen 37:3f

3|יושראל] אהב את־יוסף מכל־בניו כי־בן־זקנים הוא לו ועשה לו כתנת פסים:4 ויראו אחיו כי־אתו אהב

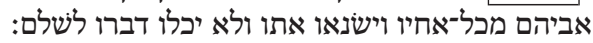

This assumption is supported by further links between Gen 37:3-4 and the ancestral narratives, namely the antagonism of love and hatred and the reference to Joseph as son of old age.

\subsection{Jacob-Israel's Unequal Distribution of Affection}

Within Gen 37:3-4 the unequal distribution of affection is expressed terminologically through the terms שנא While the positive emotion refers to Israel and his affection towards Joseph, the latter verb designates the brothers' reaction to paternal preference. ${ }^{7}$ They hate Joseph, because Israel distributes his love unequally amongst his sons. The same imbalanced distribution of affection is recounted for Jacob in Gen 29. Upon serving Laban for his younger daughter, Rachel, Jacob is first deceived and married to Rachel's older sister Leah. He then

${ }^{5}$ Cf. R. G. Kratz, Die Komposition der erzählenden Bücher des Alten Testaments (Göttingen: Vandenhoeck \& Ruprecht, 2000), 281-286.

${ }^{6}$ Cf. B. Willmes, "Objektive Ereignisse bei textinterner Literarkritik: Einige Anmerkungen zur Subjektivität literarkritischer Beobachtung. Harald Schweizers Studie. Die Josefsgeschichte," BN 67 (1993), 54-86, here 58.

${ }^{7}$ For considerations on the motif of paternal preference cf. B. J. VAN DER MERWE, "Joseph as successor of Jacob," in Studia Biblia et Semitica (ed. W. C. van Unnik and A. S. van der Woude; Wageningen: Wageningen Academic Publishers, 1966), 221-232, here 228f, or B. JoHnson, "Die Josephserzählung und die Theodizeefrage," in Nachdenken über Israel (ed. H. M. Niemann, M. Augustin and W.H. Schmidt; BEAT 37; Frankfurt a. M.: Peter Lang, 1994), 27-36, here 27. 
serves Laban another seven years in order to gain Rachel's hand in marriage. The account of courtship concludes in Gen 29:30 with the observation that Jacob loved Rachel more than Leah. The motif of greater love segues into the following birth accounts, in which Jacob's greater love for Rachel is juxtaposed with Leah's identification as שנואה.

Comparing the above passages, it is most striking that they not only concord regarding the opposition of love and hatred, but do so in the context of a conflict between siblings that is described in terms of their respective relation with Jacob-Israel. While some may say that the motif is part of a common traditional theme and the terminology to be expected in this regard, within the Hebrew Bible the exact constellation only occurs in the above instances. Both motif and terminology may then, perhaps, be easiest explained as a deliberate bridge between the Jacob stories and the Joseph story, through which Jacob-Israel projects his greater love for Rachel onto her first-born son. ${ }^{8}$

Gen 29:30-31

30 ויבא גם אל־רחל ויאהב גם־את־רחל מלאה ויעבד עמו עוד שבע־שנים אחרות:

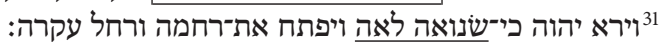

Gen 37:3-4

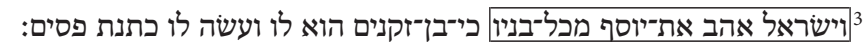

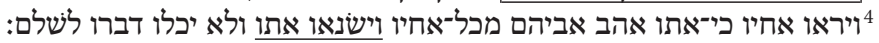

\subsection{Joseph, Son of Old Age}

The aspect of election contrary to genealogy is strengthened by another link to the ancestral narratives, i.e. the reference to Joseph as son of old age. Again, the exact reference only occurs in three instances (Gen 21:2, 7; 37:3). ${ }^{9}$

Gen 21:2, 7

2ותהר ותלד שרה לאברהם בן לזקניו למועד אשר־דבר אתו אלהים:

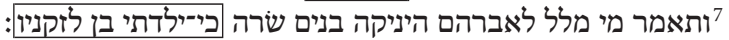

\footnotetext{
${ }^{8}$ For the interrelation with Gen 29 cf. esp. R. Lux, Josef. Der Auserwählte unter seinen Brüdern (Biblische Gestalten 1; Leipzig: Evangelische Verlagsanstalt, 2001), 50. Cf. further S. Tengström, Die Hexateucherzählung: Eine literaturgeschichtliche Studie (CB.OTS 7; Lund: CWK Gleerup, 1976), 42; T. NAumanN, "Der Vater in der biblischen Josefserzählung," ThZ 61 (2005), 44-64, here 48, or R. DE Hoop, Genesis 49 in its Literary and Historical Context (OTS 39; Leiden: Brill, 1999), 323. A different view is held by W. DieTrich, Die Josephserzählung als Novelle und Geschichtsschreibung: Zugleich ein Beitrag zur Pentateuchfrage (BThSt 14; Neukirchen-Vluyn: Neukirchener Verlag, 1989), 46; J. LanCKaU, Der Herr der Träume: Eine Studie zur Funktion des Traumes in der Josefsgeschichte der Hebräischen Bibel (ATANT 85; Zürich: TVZ, 2006), 166, or J. WöHrLe, Fremdlinge im eigenen Land: Zur Entstehung und Intention der priesterlichen Passagen der Vätergeschichte (FRLANT 246; Göttingen: Vandenhoeck \& Ruprecht, 2012), 105.

${ }^{9}$ Cf. ילד זקנים in Gen 44:20 with regard to Benjamin.
} 
Gen 37:3

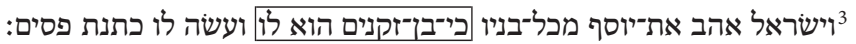

Within Gen 37 the reference provides a reason for Israel's greater love, while the statement itself is not indicated by the birth accounts in Gen $29 \mathrm{f}$. Whereas Joseph may be the second last son born to Jacob, the father's age is of no importance for the story line. The opposite, however, applies to the second passage, in which the reference occurs. Gen 21 recounts the birth of Isaac, who was promised to Abraham by the deity in Gen 18:10. In spite of their old age, Yhwh promises that Abraham will beget a son, whom Sarah, the legitimate wife, will deliver. This son - Isaac, son of Abraham's old age - will continue his father's lineage and supersede his older brother Ismael, born by the handmaid Hagar.

The above circumstances regarding the birth of Isaac may help us shed light on the seemingly incorrect reference to Joseph as son of old age in Gen $37 .{ }^{10}$ Just like Isaac before him, Joseph is not the oldest son of his father. Yet, he is the son of the beloved, the legitimate wife and as such will continue his father's lineage. Should these considerations apply, the literary evidence would, again, suggest that Gen 37:3-4 were written in awareness of certain passages from the ancestral narratives. ${ }^{11}$ Within Gen 37:3-4 the theme continues the concern of genealogical descent from the right mother as already implied in the motif of greater love.

In sum v. 3-4 include three major elements, each of which creates a link with the ancestral narratives. ${ }^{12}$

Gen 37:3f

3|וישראל אהב את־יוסף מכל־בניו כַי־ב־זקנים הוא לו ועשה לו כתנת פסים:4 ויראו אחיו כי־אתו אהב

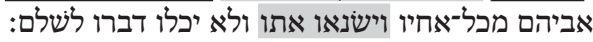

Gen $21: 2,7$

2ותהר ותלד שׁרה לאברהם בן לזקניו למועד אשר־־בר אתו אלהים:

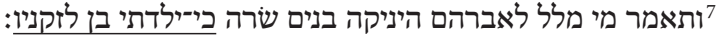

${ }^{10}$ A connection between both passages could be implied in Josephus, Ant.: "Josephus specifically characterises the youth of one other patriarch in terms of practising virtue. Isaac, also passionately beloved because he was the son of old age, is said to have 'endeared himself to his parents by the practice of every virtue, showing a devoted filial obedience and a zeal for the worship of God' [Ant. 1:222]" in M. Nienoff, The Figure of Joseph in Post-Biblical Jewish Literature (Leiden: Brill, 1992), 87.

${ }^{11}$ Against the backdrop of this assumed purpose the discrepancy between Gen 37:3f and Gen $29 \mathrm{f}$ dissolves, and may not support the formerly independent existence of the Joseph story as purported by K. Schmid, "Die Josephsgeschichte im Pentateuch," in Abschied vom Jahwisten. Die Komposition des Hexateuch in der jüngsten Diskussion (ed. J.C. Gertz et al.; BZAW 315; Berlin: Walter de Gruyter, 2002), 83-118, here 94, or L. SснміDт, "Literarische Studien zur Josephsgeschichte," in The Traditional Prayer in the Psalms (ed. A. Aejmelaeus; BZAW 167; Berlin: Walter de Gruyter, 1986), 125-194, here $149 \mathrm{f}$.

${ }^{12}$ Different views are held by Schmid, "Die Josephsgechichte im Pentateuch" (see n. 11), 94, or Schmidt, "Studien" (see n. 11), $149 \mathrm{f}$. 
Gen 29:30f

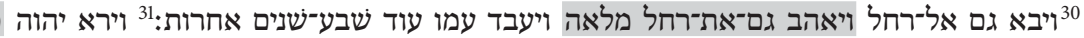

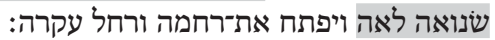

Gen 32:29

29 ויאמר לא יעקב יאמר עוד שמך כי אם־ישראל כי־שרית עם־אלהים ועם־אנשים ותוכל:

The cumulative evidence suggests that those verses intend to introduce a story, in which Yhwh's journey with the patriarchs continues in Joseph and in Egypt. It is to this journey to Egypt, more precisely its cause, its extent and its content, to which we will now turn our attention. Our endeavor, again, begins in Gen 37 with the two causes for fraternal hatred.

\section{Original Scope and Function(s) of the Joseph Story}

\subsection{The Double Incentive for Fraternal Hatred in Gen 37}

As mentioned before, the double incentive for fraternal hatred has often been considered an indication for diachronic distinction. An independent existence of both aspects has already been refuted, the exact nature of their relation, however, remains to be verified. As seen above, the passage on paternal preference moves from the father's perspective to the brother's perspective. The father loves Joseph more than his other sons. The brothers perceive this imbalance and start to hate Joseph. The reason for the father's preference roots in his greater love for Joseph's mother. Joseph's election thus rests on genealogical implications.

The section on Joseph's dreams picks up on the fraternal perspective depicted in v. 4. The verse now ignores the father and instead renders the fraternal conflict the sole center of attention. ${ }^{13}$ In this regard, Joseph, who had remained a passive recipient of paternal preference in v. 3-4, is newly introduced as active agent, who increases hatred - albeit unintentionally. For unknowing of their true meaning, Joseph reveals to his brothers the image of his dreams and thus incites their anger.

A first dream account extends from v. 5 to v. 8 and is framed by reference to Joseph's dreams and their ramification, i.e. fraternal hatred. ${ }^{14}$ The conclusion to the dream account in $\mathrm{v}$. $8 \mathrm{~b}$ presupposes multiple dreams and suggests that the

${ }^{13}$ Cf. Levin, Jahwist (see n. 4), 267-271.

${ }^{14}$ For the framing function of the above references cf. B. BECKING, "They hated him even more: Literary Technique in Genesis 37.1-11," BN 60 (1991), 40-47, here 41.45f; P. WeIMAR, "Die Josefsgeschichte als theologische Komposition: Zu Aufbau und Struktur von Gen 37," in Studien zur Josefsgeschichte (ed. P. Weimar; SBAB 44; Stuttgart: Katholisches Bibelwerk, 2008), 27-60, here $30 \mathrm{f}$, or N. Keвекus, Die Joseferzählung: Literaturkritische und redaktionsgeschichtliche Untersuchungen zu Gen 37-50 (Münster: Waxmann, 1990), 15 f. 
single depiction of a dream image in v. 7 constitutes the exemplary depiction of a recurring dream image. ${ }^{15}$

Gen 37:5-8

5ויחלם יוסף חלום ויגד לאחיו ויוספו עוד שנא אתוּ:6 ויאמר אליהם שמעו־נא החלום הזה אשר חלמת אלמתי:

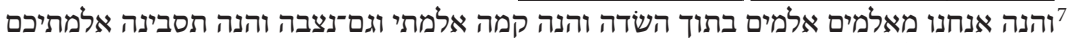
ותשתחוין לאלמתי:

Plural Dreams: exemplary depiction of a recurring dream image (v. 7)

8ויאמרו לו אחיו המלך תמלך עלינו אם־משול תמשל בנו ויוספו עוד שנא אתו על־חלמתיו ועל־דבריו:

Against the above backdrop, the actual illustration of a second dream in v. 9 lags behind and further distinguishes itself from v. 7 to an extent that suggests different authorship. ${ }^{16}$ While the first dream depicts Joseph and his brothers as themselves and only conceals the metaphoric meaning of the sheaves and their proskenysis, the second dream mentions Joseph, who is bowed down to by luminaries. ${ }^{17}$

${ }^{15}$ This observation is problematic with regard to K. ScHmid, "Josephs zweiter Traum Beobachtungen zu seiner literarischen Funktion und sachlichen Bedeutung in der Josephsgeschichte (Gen 37-50)," ZAW 128/3 (2016), 374-388, here 381, whose claim that the second dream constitutes an original element within the Joseph story not least rests on the observation that Gen 37:19f; 42:9 presuppose a plurality of dreams: "Angesichts des Niederfallens der Brüder anlässחלםות [sic!]). Es ist hier von 'Träumen' im Plural die Rede, es sind also beide Träume aus Gen 37 im Blick."

${ }^{16}$ C. Levin, Jahwist (see n. 4), 272; H. Schweizer, Die Josefsgeschichte. Konstituierung des Textes (Tübingen: Francke, 1991), 128-132, or L. RupperT, Genesis: Ein kritischer und theologischer Kommentar (FzB 118; Würzburg: Echter, 2008), 99, also consider the second dream an addition. H. Grebmann, "Ursprung und Entwicklung der Joseph-Sage," in Eucharisterion. Studien zur Religion und Literatur des Alten und Neuen Testaments (ed. H. Schmidt; FRLANT 36; Göttingen: Vandenhoeck \& Ruprecht, 1923), 1-55, here 19, however, considers the first dream a later imitation of the second: "Denn die Verneigung ist bei menschlichen oder göttlichen Lebewesen anschaulicher als bei Sachen, nun gar bei Garben, deren Halme nach orientalischer Sitte ganz kurz abgeschnitten werden, weil man kein Stroh gebraucht." In the context of older literary critical approaches the dreams were mostly attributed to E; cf. already WELLHAUSEN, Composition (see n. 3), 54. More recent diachronic approaches often consider the dreams part of a Reuben-layer; cf. H.-C. Schmit T, Die nichtpriesterliche Josephsgeschichte: ein Beitrag zur neuesten Pentateuchkritik (BZAW 154; Berlin: Walter de Gruyter, 1980), 26, or KebeKus, Joseferzählung (see n. 14), 344.

${ }^{17}$ The imagery of the second dream has long been a bone of contention. Gunkel, Genesis (see n. 3), 405, or RUPPERT, Genesis (see n. 16), 106, assume that the stars represent the Babylonian zodiac. This was refused by Holzinger, Genesis (see n. 3), 225, or C. Westermann, Genesis (BKAT I/2; Neukirchen-Vluyn: Neukirchener Verlag, 1981), 30, who pointed out that within the internal logic of dream and interpretation the stars symbolize Joseph's eleven brothers. With regard to the general image depicted in the second dream H. Grebmann, "Ursprung" (see n. 16), 18, points to a passage from Ahiqar: "Dagegen bietet sich eine genaue Entsprechung im heidnischen-aramäischen Achikar-Roman: Da wird der assyrische König Sanherib mit dem Himmelsgott verglichen, dem Sonne, Mond und Sterne untertan sind."

The approach taken by LANCKAU, Herr (see n. 8), 173.183.295-340, seems little compelling. Lanckau assumes that "die Himmelserscheinungen en bloc als Symbol für das nichtisraelitische 
Gen 37:7, 9

7והנה אנחנו מאלמים אלמים בתוך השדה והנה קמה אלמתי וגם־נצבה והנה תסבינה אלמתיכם

ותשתחוין לאלמתי:

9יויחלם עוד חלום אחר ויספר אתו לאחיו לאתמיו ויאמר הנה חלמתי חלום עוד והנה השמש והירח ואחד

עשר כוכבים משתחוים לים

The identity of the luminaries is unveiled in v. 10 as (eleven) brothers, mother, and father. The astrological imagery of the second dream remains a foreign element within the Joseph story, the proskynesis of mother and father is never fulfilled. Indeed, the image depicted in v. 9 has no explicit echo in Gen 37-50. This lack of resonance may represent the most telling difference towards v. 7, which is echoed frequently and over against v. 9 constitutes a pivotal element in creating an elaborate arc of suspense. It is to this narrative arc, to which I will now turn my attention.

As has already been hinted at, the dream in v. 7 moves between indirect and direct association, when Joseph and his brothers are identified as protagonists, while the relevance of the sheaves remains polyseme and requires interpretation. The brothers in v. 8 offer their own interpretation of the dream image, which solely considers the aspect of proskynesis and does not account for the agricultural imagery.

Gen 37:7f

7הנה אנחנו מאלמים אלמים בתוך השדה והנה קמה אלמתי וגם־נצבה והנה תסבינה אלמתיכם ותשתחוין לאלמתי:

8ויאמרו לו אחיו המלך תמלך עלינו אם־משול תמשל בנו ויוספו עוד שנא אתו על־חלמתיו ועל־דבריו:

That the interpretation assumed by the brothers is incorrect, can be learned from the subsequent context, in which the meaning of the imagery is revealed. ${ }^{18}$ This concerns first and foremost the context of fraternal reunion in Gen 42. ${ }^{19}$ Towards

Volk [hier also Ägypten] stehen.” The number mentioned within the dream, i.e. 11 thus bears a separate meaning and may not be understood as reference to Joseph's brothers. Rather, in analogy with Gen $40 \mathrm{f}$ the number needs to be interpreted as a certain period of time, which Lanckau identifies as $13(1+1+11)$ and $22(1+1[x 11])$ years. In this regard the former period marks the time until Joseph's elevation by Phraoh, while the latter indicates the time when Joseph saves his family from extinction. The assumption by Lanckau is problematic for a number of reasons. First, the analogy with Gen $40 \mathrm{f}$ is inconsistent. For in Gen $40 \mathrm{f}$ the number presented in the dream is directly identified with a certain period of time: seven cows = seven years. In the case of Joseph's second dream, however, the number mentioned in Joseph's dream needs to be associated with different mathematic equations that are neither implied in the dream itself nor in the interpretation of the dream by Jacob-Israel in Gen 37:10. Moreover, the time spans that Lanckau associates with different periods in Joseph's life rest on a chronological framework that poses serious literary critical problems in and by itself.

${ }^{18}$ Cf. LancKau, Herr (see n. 8), $380 \mathrm{f}$.

${ }^{19}$ Cf. H. Seebass, Genesis III: Josephsgeschichte $(37,1-50,26)$ (Neukirchen-Vluyn: Neukirchener Verlag, 2000), 87, or Keвекus, Joseferzählung (see n. 14), 97f. Differently, however, B. JАСов, Das erste Buch der Tora: Genesis (Stuttgart: Calwer, 2000), 765; J.-D. DöHLInG, "Die 
the end of Gen 41 Joseph was promoted to overseer of the grain supply in Egypt. As such he sells grain to the inhabitants of Egypt and the entire world. Thus, when the famine strikes Canaan and his brothers go down to Egypt to purchase grain, they come before Joseph and bow down to him. It is only then that he remembers his dreams, apparently grasping the divine revelation included therein. The dreams that led to fraternal hatred and thus to Joseph's sale to Egypt contain a divine message that through symbolic imagery depicts God's plan to save Israel from starvation. This underlying theme of divine guidance is successively unfolded in Gen 45:4-7: "Now don't be grieved, nor angry with yourselves, that you sold me here, for God sent me before you to preserve life [...]." According to these interrelations Gen 37:5-8 introduce a narrative arc that extends at least to Gen 45 and that subsumes the entire context in between under the heading of divine promise and guidance. ${ }^{20}$

Gen 37:5-8

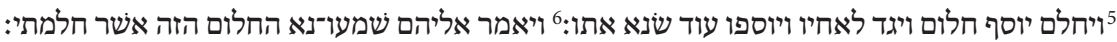

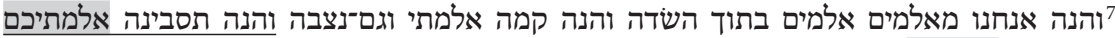

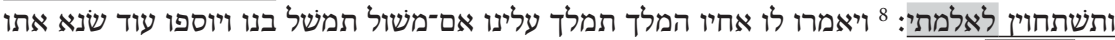
על־חלמתיון ועל־דבריו:

Gen 42:6, 9

6יוסף הוא השליט על־הארץ הוא המשביר לכל־עם הארץ ויבאו אחי יוסיוסף יוסף וישתחוו־לו אפים ארצה:

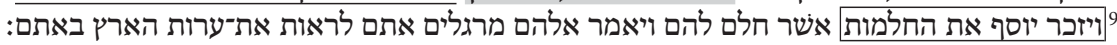

Gen 45:4-7

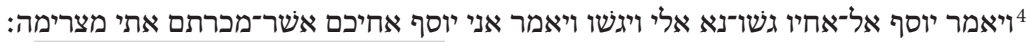

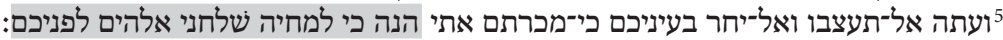

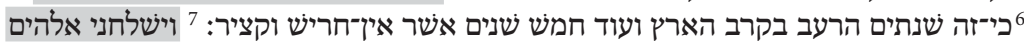

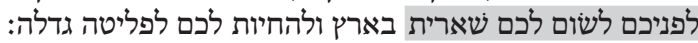

Both the concentration on fraternal conflict rather than paternal preference and the theme of divine election rather than genealogical descent distinguish Gen 37:5-8 from Gen 37:3-4. From a conceptual perspective, the exclusive concentration on fraternal conflict shifts focus from the establishment of Joseph's status as preferred part of Israel towards the contestation of this status by his brothers. $^{21}$ This aspect becomes most apparent in the decision for fratricide in Gen 37:19-20. The plan to kill Joseph draws back explicitly on the dreams from v. $8 b^{22}$ and aims to counteract the fulfillment of what the brothers consider a product of

Herrschaft erträumen, die Träume beherrschen. Herrschaft. Traum und Wirklichkeit in den Josefträumen (Gen 37,5-11) und der Israel-Josefsgeschichte," BZ 50/1 (2006), 1-30, or G. J. WENHAM, Genesis 16-50 (Dallas, TX: Thomas Nelson Inc., 1996), 406.

${ }^{20}$ Cf. Lanckau, Herr (see n. 8), $380 \mathrm{f}$.

${ }^{21}$ Cf. Levin, Jahwist (see n. 4), 267-271.

${ }^{22}$ For this interrelation cf. already Gunkel, Genesis (see n. 3), 402-403. Differently, WeLLHausen, Composition (see n. 3), 54, who attributes V. 2b-11 to E, while V. $19 \mathrm{f}$ represent part of J. 
Joseph's pretentiousness. ${ }^{23} \mathrm{He}$ may exalt himself above them, yet they will show the master of dreams ${ }^{24}$ what the figment of his imagination is worth.

Gen 37:5-8, $19 \mathrm{f}$

5 דוהנה אנחנו מאלמים אלמים בתוך השדה והנה קמה אלמתי וגם־נצבה והנה תסבינה אלמתיכם

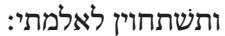
8ויאמרו לו אחיו המלך תמלך עלינו אם־משול תמשל בנו ויוספו עוד שנא אתו על־חלמתיו ועל־דבריו: 19 ויאמרו איש אל-אחיו הנה בעל החלמות הלזה בא:20 ועתה לכו ונה ונהרגהו ונשלכהו באחד הברות ואמרנו חיה רעה אכלתהו ונראה מה־יהיו חלמתיוּ:

Since the dreams, however, represent divine revelation, it is not Joseph, who will be taught humility. Rather, the dreams endorse Joseph's status and highlight the futility of human agency in view of divine predestination..$^{25}$ Given this evidence we may conclude that Gen 37:5-8 adopt a motif already extant in Gen 37:3-4 (fraternal hatred), which is now adapted to a new line of argument. Thus, both passages not merely provide a double incentive for fraternal hatred. Rather, the combination of adoption and adaptation suggests a shift in authorial concern and could thus imply a change of hand. ${ }^{26}$

Gen 37:3f: Establishment of Joseph's status among his brothers

3יוישראל אהב את־יוסף מכל־בניו כי־ב־־קנים הוא לו ועשה לו כתנת פסים:4 ויראו אחיו כי־אתו אהב אביהם מכל־אחיו וישנאו אתו ולא יכלו דברו לשלם:

Gen 37:5-8: Contestation of Joseph's status among his brothers

6ויחלם יוסף חלום ויגד לאחיו ויוספו עוד שנא אתום

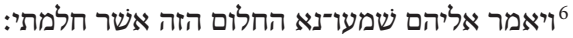
7'והנה אנחנו מאלמים אלמים שמים בתוך השדה והשר חלמה קמה אלמתי וגם־־צבה והנה תסבינה אלמתיכם

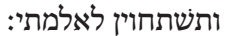
8ויאמרו לו אחיו המלך תמלך עלינו אם־משול תמשל בנו ויוספו עוד שנא אתו על־חלמתיו ועל־דבריו:

Irrespective of any diachronic distinction, however, both aspects prepare for a narrative arc that is concerned with Joseph's permanent presence in Egypt. ${ }^{27}$ In regards to the latter aspect, a general affiliation of Gen 39-41 with paternal preference and of Gen $42-45$ with Joseph's dreams may be observed. ${ }^{28}$ Gen 37:34 establish Joseph as successor of his father, Jacob-Israel, and justify this circum-

\footnotetext{
${ }^{23}$ Cf. Lanckau, Herr (see n. 8), $380 \mathrm{f}$.

${ }^{24}$ Contrary to the assumption by M. FIEger and S. Hodel-Hoenes, Der Einzug in Ägypten: בעל Ein Beitrag zur alttestamentlichen Josefsgeschichte (Bern: Peter Lang, 2007), 67, the term may not imply a "negativ konnotierte Assoziation zum kanaanäischen Gott Baal." Rather, the term may be derived intratextually from Joseph's dream in Gen 37:7 and serve as reason for the intended fratricide.

${ }^{25}$ Cf. Lanckau, Herr (see n. 8), $380 \mathrm{f}$.

${ }^{26}$ Cf. Levin, Jahwist (see n. 4), 267-271, or Kratz, Komposition (see n. 5), 281-286.

${ }^{27}$ Cf. Kratz, Komposition (see n. 5), 281-286.

${ }^{28} \mathrm{Cf}$. in general the observation made by Levin, Jahwist (see n. 4), 298-306.
} 
stance genealogically by reference to his descent from Rachel (cf. Gen 29f). This focus on Joseph's special status concords with the narration of his personal fate in Egypt that continues the stories surrounding his father - albeit in Egypt. From a politico-historical perspective this narrative arc implies the existence of a diaspora in Egypt that is identified not only as part of Israel, but as the preferred part of Israel. ${ }^{29}$ Gen $42-45$ presuppose the existence of Joseph in Egypt and challenge his role amongst his brothers and, therefore, in Israel. This perspective suggests that the acknowledgment of the Egyptian diaspora as part of Israel has not remained uncontested. In response to this controversy, the motif of dreams as a form of divine revelation creates a narrative arc that serves to sanction Joseph's role as part of Israel not by genealogy, but by divine will. As we have seen before, this narrative arc extends at least to Gen 45 . Whether or not it may originally have continued beyond this chapter, will be discussed in the following. ${ }^{30}$

\subsection{Jacob's Spirit and Israel's Death}

From a conceptual perspective, it may be advisable to keep in mind that Gen $37-45^{\star}$ are primarily concerned with the question of how Joseph, who lives in diaspora, can be considered part of Israel. In this regard, Egypt is perceived of as long-term residence of Joseph, rather than as stop-over for Israel before the exodus. The emphasis on Joseph's permanent residence in diaspora is only abandoned in the latter part of the Joseph story, when focus shifts towards Israel's journey to Egypt. Literary-critically speaking, this shift in emphasis becomes manifest towards the end of chapter 45.

In v. 25 we learn that Joseph's brothers return to their father Jacob in Canaan. Subsequent to their arrival, they inform their father of Joseph's survival. Once the impact of this good news dawns on Jacob, his spirit revives. In the greater context of the Joseph story this revival harkens back to the beginning in Gen 37, where Jacob is inconsolable in light of Joseph's alleged death. His life only resumes, now that he learns of his son's survival. The inextricable bond between father and son is further strengthened by the double reference to חיה in Gen 45:26-27 that creates a direct connection between Joseph's survival (עוד יוסף חיה (עיחי) and Jacob's revival (ותחי רוח יעקב). Both macro- and micro-contextual connections thus suggest

\footnotetext{
${ }^{29}$ Cf. Kratz, Komposition (see n. 5), 281-186.

${ }^{30}$ For the diaspora motif in general cf. A. Meinhold, "Die Gattung der Josephsgeschichte und des Estherbuches: Diasporanovelle I," ZAW 87 (1975), 306-324, here 320; KrATZ, Komposition (see n. 5), 284-286, or T. RÖMER, “Deux Repas 'en miroir' dans l'histoire de Joseph (Gn 37-50)," RHPhR 93/1 (2013), 15-27, here 20 f. Cf. also H. SEebass, “Zur Quellenscheidung in der Josephsgeschichte," in Joseph. Bibel und Literatur (ed. F. W. Golka and W. Weiß; Oldenburgische Beiträge zu Jüdischen Studien 6; Oldenburg: Bibliotheks- und Informationssystem der Carl von Ossietzky Universität Oldenburg, 2000), 25-36, here 29, who reckons "daß Gen 39-41, sie und nur sie, in die Nähe dessen kommen, was man eine Diasporanovelle nennt.”
} 
that the underlying concern here is Joseph's survival as the presupposition for the father's well-being. ${ }^{31}$

Gen 37:34f

וימאו ויקע יעקב שמלתיו וישם שק במתניו ויתאבל על-בנו ימים רבים:35 ויקמו כל־בניו וכל־בנתיו לנחמו וימאן להתנחם ויאמר כי־ארד אל־בני אבל שאלה ויבך אתו אביו:

Gen 45:25-27

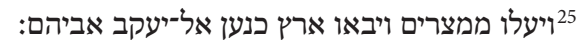

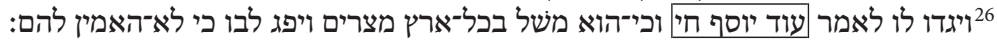

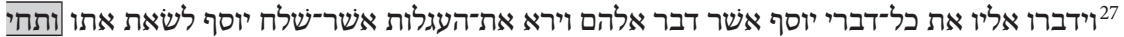
רוח יעקב אביהם:

The focus on Jacob's well-being is abandoned in v. 28. The verse recounts a direct speech by the father, who is now referred to as Israel. ${ }^{32}$ Israel repeats the information of Joseph's survival, yet discusses it not in relation to his own revival, but against the backdrop of his imminent death. The imminence of his death serves as occasion for his immediate sojourn to Egypt that commences with Gen 46:1. Over against v. $26 \mathrm{f}$, v. 28 does thus not create a narrative bridge to the beginning of the Joseph story. Rather, it introduces a new aspect that is resumed in Gen $46 \mathrm{ff}$.

Gen 45:25-27, 28

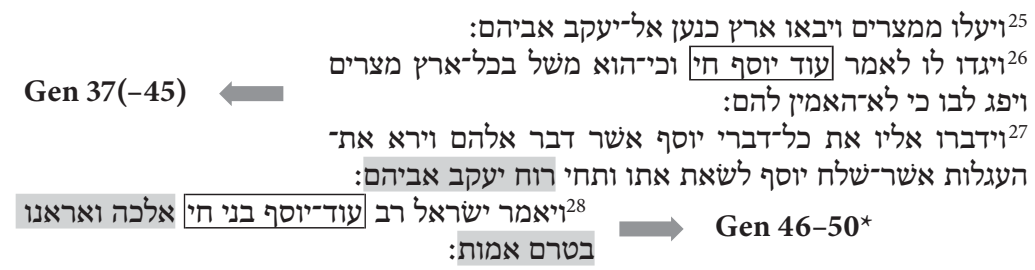

While no one of the above observations in and by itself would carry the weight of a diachronic distinction, the cumulative evidence suggests different authorship for both passages. The former seems to conclude a story that is primarily concerned with Joseph's existence in the Egyptian diaspora and the ramifications this existence may entail for his identity as part of Israel. Joseph is the favorite son of Israel. He is sold to Egypt, where he is promoted to high offices and even

${ }^{31}$ Cf. V.P. Hamilton, The Book of Genesis: Chapters 18-50 (Grand Rapids, MI: Eerdmans, 1995), 587: "In ch. 37 Jacob did believe his sons when they were lying to him. In ch. 45 Jacob disbelieves his sons when they are being truthful with him."

${ }^{32}$ Cf. already ЈАСОв, Genesis (see n. 19), 824: "Es ist undenkbar, daß die Tora ohne besondere Absicht beide Namen unmittelbar aufeinander folgen lasse." He explains the change of names as follows: "Auf die Schreckensbotschaft, daß [Josef] nicht mehr sei, war der Vater wieder zu Jakob geworden und hatte als dieser seine Kleider zerrissen [...], die Freudenbotschaft, daß der Totgeglaubte lebt, erweckt Jakob zum früheren Leben und wandelt ihn wieder zu Israel zurück." Further synchronic explanations are offered by Hamilton, Genesis (see n. 31), 58; W. Brueggemann, Genesis: Interpretation (Atlanta, GA: Westminster John Knox, 2004), 351, or J. ЕвACH, Genesis (HTKAT; Freiburg: Herder, 2007), $410 \mathrm{f}$. 
saves his family from extinction. Only when Jacob-Israel is informed of Joseph's survival abroad, can he continue his life at home. ${ }^{33}$

Beyond this narrative arc, Gen 45:28 seems to commence a new story line, ${ }^{34}$ which in view of internal evidence concentrates on two aspects: Israel's reunion with Joseph in Egypt and his imminent death. According to v. 28 both aspects are interrelated: Since his death is soon to occur, Israel sojourns to Egypt, where he intends to meet with Joseph. No sooner said than done, Israel departs to Egypt (Gen 46:1), where he is reunited with his son (Gen 46:29-30). During this reunion Israel reveals to Joseph his frail health: I am ready to die now that I have seen your face that you are alive (Gen 46:30). Contrary to this announcement, the reader requires quite some patience to learn of Israel's decease. For it is only towards the end of Gen 47 that the announcement begins to fulfill (יקרבו ימות). ישראל למות).

Gen 45:28

28 ויאמר ישוֹראל רב עוד־יוסף בני חי אלכה ואראנו בטרם אמות:

Gen 46:1, 30

1יוסע ישראל וכל־אשר־לו ויבא בארה שבע ויזבח זבחים לאלהי אביו יצחק:

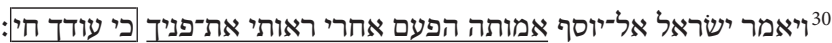

Gen 47:29

292ויקרבו ימי־ישראל למות ויקרא לבנו ליוסף ויאמר לו אם־נא מצאתי חן בעיניך שים־נא ידך תחת

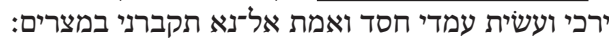

In the face of death, Israel calls for Joseph and wrests a promise from him ${ }^{35}$ : "If I have found favor with you, [...] do not bury me in Egypt. [...] He answered, "I will do as you have said". Reassured that his death in Egypt will not lead to his burial abroad, Israel bends over the head of the bed. Regardless of the cryptic terminology, the Hebrew וישתחו ישראל על־ראש המטה in Gen 47:31 seems to initiate the process of dying that is finalized in Gen 49:33. ${ }^{36}$ There, Israel draws up his

${ }^{33}$ Cf. already H. Gunkel, "Die Komposition der Joseph-Geschichten," ZDMG 76 (1922), 55-71, here 69, who assumed that the "ursprüngliche Erzählungsstoff [...] mit der Wiedervereinigung der Familie sein Ende erreicht." Cf. more recently Dietrich, Novelle (see n. 8), 53-66; Kebekus, Joseferzählung (see n. 14), 244-250, or Kratz, Komposition (see n. 5), 284. Seebass, Josephsgeschichte (see n. 19), 27, or ScHмid, “Die Josephsgeschichte im Pentateuch” (see n. 11), 95-106, explicitly reject this assumption.

${ }^{34}$ Cf. Levin, Jahwist (see n. 4), 302-306, or Kratz, Komposition (see n. 5), 286-281.

${ }^{35} \mathrm{Cf}$. against the backdrop of our following assumptions Westermann, Genesis (see n. 17), 205: "Es ist möglich, daß der Erzähler in diesem Wunsch des Sterbenden dessen ahnenden Vorblick in die Zukunft zum Ausdruck bringen will: die Zukunft seiner Familie, die Zukunft der Söhne Israels wird in Kanaan, nicht in Ägypten sein."

${ }^{36}$ For this understanding of Gen 47,31 וישתחו ישראל על־ראש המטה cf. mutatis mutandis E. BLum, Die Komposition der Vätergeschichte (WMANT 57; Neukirchen-Vluyn: Neukirchener Verlag, 1985), 250; J. VAn Seters, Prologue to History: The Yahwist as Historian in Genesis (Zürich: TVZ, 1992), 320, or SCHWEIZER, Josefsgeschichte (see n. 16), 290. For different propositions 
feet on the same bed (ויאסף רגליו אל־המטה), over the head of which he had bent before. In reaction to Israel's decease, Joseph throws himself on his father's face, ${ }^{37}$ weeps over him, and kisses him. The subsequent context recounts the fulfillment of his promise not to bury his father in Egypt (Gen 47:29-31): "And Joseph went up to bury his father [...] and he mourned for his father for seven days. [...] And Joseph returned to Egypt [...] after he had buried his father." ${ }^{\prime 3}$

Gen 47:29-31

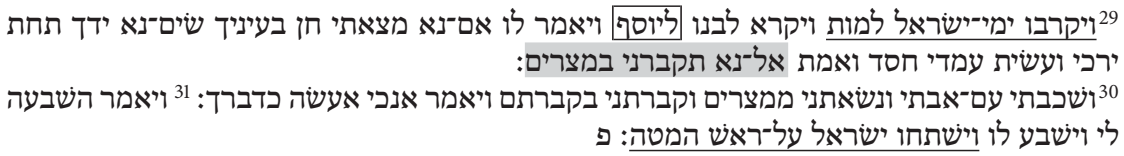

Gen $49: 33^{*}$

[....] [...]

Gen $50: 1,7 \mathrm{a}, 10 \mathrm{~b}, 14^{\star}$

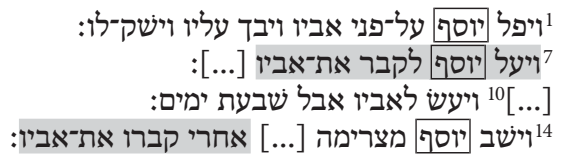

As can be perceived from the above-sketched outline, Gen 46-50 include passages that are explicitly foreshadowed by Israel's resolution from Gen 45:28 and that are closely interrelated amongst each other. The point of departure is Israel's imminent death that prompts him to go down to Egypt and reunite with Joseph. Having arrived in Egypt, Israel unveils to his son the imminence of his death and soon makes him promise to return his corpse home. Joseph promises and his father dies. Subsequently, Joseph fulfills his promise.

In view of the close terminological and conceptual interrelations between the above passages, the combination of Israel's presence and death in Egypt may constitute the oldest narrative strand within Gen 46-50. Its intended function is not far to seek: Israel's sojourn to and presence in Egypt anticipates the constellation presupposed in Exod 1. The death of the patriarch marks the caesura

cf. J. Skinner, Genesis (2nd ed.; Edinburgh: T \& T Clark, 1951), 503; Westermann, Genesis (see n. 17), 207, or Ruppert, Genesis (see n. 16), 425.

${ }^{37}$ For the diachronic distinction within Gen 49:33 cf. already Holzinger, Genesis (see n. 3), 222: "Aus Cap. 49 gehört P v. 1a [...], in unmittelbarem Anschluss daran v. 28b von ויברך an v. 2932.33(a ?)b." Cf. further Gunkel, Genesis (see n. 3), 496; G. von Rad, Das erste Buch Mose (Göttingen: Vandenhoeck \& Ruprecht, 1953), 369; Westermann, Genesis (see n. 17), 220-229; Schmidt, "Studien” (see n. 11), 127 f; Ruppert, Genesis (see n. 16), 456; Levin, Jahwist (see n. 4), $311 \mathrm{f}$, or U. SCHORN, Ruben und das System der ZwölfStämme Israels (BZAW 248; Berlin: Walter de Gruyter, 1997), $250 \mathrm{f}$.

${ }^{38}$ With regard to the above diachronic distinction within Gen 50 cf. Levin, Jahwist (see n. 4), 306-307, or C. BERner, Die Exoduserzählung: Das literarische Werden einer Ursprungslegende Israels (FAT 73; Tübingen: Mohr Siebeck, 2010), 18-20. 
before the emergence of the people, while the return of his corpse prefigures the coming exodus. ${ }^{39}$ Having buried his father's corpse, Joseph returns to and remains in Egypt and thus guarantees the genealogical link between the late patriarch and the nascent people. Given this close correspondence between the above narrative elements and the constellation from the beginning of the book of Exodus, it seems likely that we here encounter the oldest literary link between Genesis and Exodus. ${ }^{40}$

Accordingly, any further motifs present in the final form of Gen 46-50 would have to be considered additions. This concerns, e.g., the motif of permanent settlement in Gen $46 \mathrm{f}$ as well as Jacob-Israel's blessings and last words in Gen $48 \mathrm{f}$. A cross-check of this theory reveals that it is supported by literary critical observations pertaining to the passages at hand. The settlement passage disrupts the context between the announcement of Israel's death and its fulfillment. It further entails logical tensions. Gen 37-46 frequently emphasize the special bond between Israel and Joseph. It seems all the more surprising that Joseph neither addresses his father nor refers to his imminent death in any perceptible way. ${ }^{41}$ Instead, he turns to his brothers and his father's house and prepares for their permanent residence in Egypt. The long-term nature of this settlement, again, ignores the fragility of Israel's health, who had just unveiled to Joseph that he is about to die. In view of the overall evidence, the motif of settlement may, perhaps, be easiest explained as an addition that is influenced by the literary connection between Genesis and Exodus and that retrojects the constellation from Exod 1 into the Joseph story. As the people of Israel reside in Egypt in Exod 1, the patriarch and his family, too, take permanent residence abroad.

Gen 46:30-34

30 ויאמר ישראל אל־יוסף אמותה הפעם אחרי ראותי את־פניך כי עודך חי:

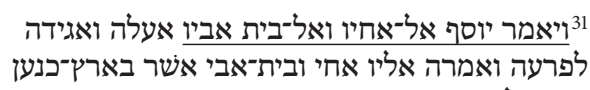

באו אלי:

32 והאנשים רעי צאן כי־אנשי מקנה היו וצאנם ובקרם

וכל־אשר להם הביאו:

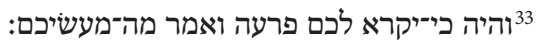

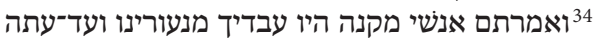

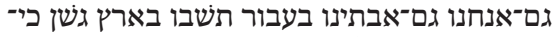

תועבת מצרים כל־רעה צאן:
- Joseph fails to react to the revelation that his father is about to die.

The long-term settlement in Egypt stands in tension with Israel's imminent death.

\footnotetext{
${ }^{39}$ Cf. KRatz, Komposition (see n. 5), 284: "Daraufhin zieht Israel nach Ägypten, wo Jakob stirbt und von wo er in das Land seiner Väter zurückgebracht wird, um dort begraben zu werden, als Angeld für die bevorstehende Befreiung Israels aus Ägypten in Ex $1 \mathrm{ff}$.'

${ }^{40}$ For the assumption of a pre-priestly connection between Genesis and Exodus cf. KRATZ, Komposition (see n. 5), 281-286, or BERNER, Exoduserzählung (see n. 38), 21-22.

${ }^{41} \mathrm{Cf}$. the synchronic observations by Евасн, Genesis 37-50 (see n. 32), 417.471.
} 
Gen 47:29-31

29 ויקרבו ימיישישראל למות ויקרא לבנו ליוסף ויאמר לו אם־נא מצאתי חן בעיניך שים־נא ידך תחת ואים

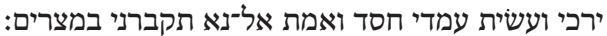

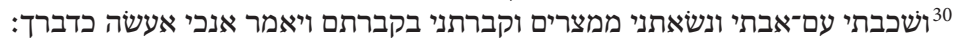
11

The secondary nature of Gen $48 \mathrm{f}$ is, again, indicated by narrative discongruity. While Gen $48 \mathrm{f}$ imply that Jacob-Israel is surrounded by extended family, Gen 50:1 only depicts Joseph's reaction to his father's death and thus mirrors the situation of a dialogue between father and son from Gen $47 .{ }^{42}$ Indeed, the chain of events narrated in Gen 50 constitutes the fulfillment of Joseph's promise not to bury his father in Egypt (Gen 47:29-31). Further conceptional considerations support the assumption that Gen $48 \mathrm{f}$ were written in light of the exodus-conquest narrative. In Gen 48 Jacob-Israel blesses his grandsons, in Gen 49 Jacob-Israel offers departing words to his sons. Both blessing and farewell speech are concerned with the true identity of Israel. Thereby, they continue aspects reflected in Gen 37-45. Gen 48f, however, do not consider the identity of Israel against diaspora existence. Rather, they seek to define who is preferred or blessed by Israel against the backdrop of his impending death that heralds the era of the people, who will leave Egypt and enter Canaan.

Gen 47:29-31: Joseph and Israel

29 ויקרבו ימי־ישראל למות ויקרא לבנו ליוסף ויאמר לו אם־נא מצאתי חן בעיניך שים־נא ידך תחת

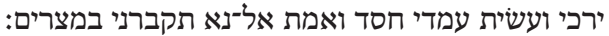

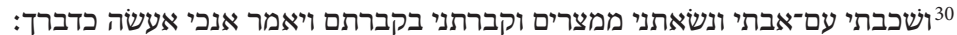

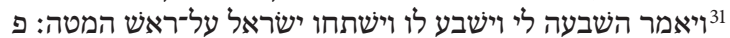

Gen 48: Jacob-Israel and his grandsons

Gen 49: Jacob-Israel and his sons

Gen 50:1: Joseph and Israel

1יפל יוסף על־פני אביו ויבך עליו וישק־לו:

This brief overview already indicates that the connection between Genesis and Exodus triggered multiple expansions of national-political concerns. In the context of this development the perception of diaspora existence shifts. Gen 37-45* are primarily concerned with defining the Egyptian diaspora as an integral part of Israel through legitimization by descent and divine will. Gen 46-50 turn Is-

${ }^{42}$ Cf. already Wellhausen, Composition (see n. 3), 60: "Kap. 50 schliesst eher an Kap. 47 an." Cf. further Naumann, "Vater" (see n. 8), 61, or EвACH, Genesis 37-50 (see n. 32), 643644. Differently Hamilton, Genesis (see n. 31), 691, assumes that "Joseph alone flung himself on his father's face may be intended as a fulfillment of an earlier word to Jacob by God that it would be Joseph who would close the eyes of his father (46:4);" similarly WenHAM, Genesis (see n. 19), 488. 
rael's presence in Egypt into the prologue to the exodus-conquest narrative. As a result, they define diaspora in Egypt not as a permanent state for Joseph, but as a transitional stage for Israel. ${ }^{43}$

\section{Conclusion}

Our study has attempted to show that the Joseph story initially represented a continuation of the ancestral narratives (Gen $37-45^{\star}$ ), with which it is connected through multiple catchword links. Via the back references to the ancestral narratives (Gen 21; 29; 32) Joseph is legitimized as his father's favorite son - a role which results in his being sold to Egypt, where he thenceforth resides and strives in exile. It is this combination of familial conflict and diaspora existence that may represent the hermeneutic key for understanding the Joseph story as continuation of the Jacob-Israel stories. The issue at stake is Joseph's exile that separates him from his family and raises the question of his affiliation with the people of Israel. Can he be part of Israel even though he lives and strives in Egypt? Gen $37-45^{\star}$ answer in the affirmative: Not only can Joseph remain a true part of Israel, whilst integrating into Egyptian society. God himself has seen to it that he was sold to Egypt so that he could guarantee Israel's survival in times of dire need. Joseph thus constitutes an essential part of Israel, without which the people would face extinction.

This diaspora novella seems to have been transformed into the narrative link between the ancestral narratives and the exodus-conquest-narrative by later hands. In this regard, Israel's sojourn to and death in Egypt represent the pivotal narrative aspects that synchronize the familial circumstances towards the end of Genesis with the national perspective at the beginning of Exodus. Israel's death in Egypt marks the end of the ancestral era; the return of his corpse to Canaan prefigures the coming exodus of the people. The genealogical link between the family and the people of Israel is represented by Joseph, who returns to Egypt, where he (and his brothers) will eventually grow into the "people of the sons of Israel" (Exod 1:9; עם בני ישראל). Through the addition of this narrative link between Genesis and Exodus Joseph's existence in Egypt is converted from a permanent diaspora existence into a waypoint of Israel's eisodus into the promised land. The Joseph story thus creates and partakes in a greater narrative that combines two formerly independent traditions of Israel's origin into an overarching salvation history.

${ }^{43}$ If and to what extent this literary evidence may shed light on historical circumstances or tradent groups, will be the primary concern of the essay presented by Reinhard G. Kratz in this volume. 



\title{
The Joseph Story: Diaspora Novella - Patriarchal Story - Exodus Narrative
}

\author{
Part II: Historical Reflections
}

\author{
Reinhard Kratz
}

Following Franziska Ede's explanation of the literary stratigraphy of the Joseph story, I will try to say something about the possible historical context. This can be no more than scholarly speculations because the text, like all texts on Israel's pre-monarchic period, makes no reference to the time period in which this literature originated. From the contents and the conceptual profiles, we can only infer a possible historical situation in which the Joseph story could have been created and imagine a possible audience for whom the story might have had meaning. In this article, I would like to focus on one particular aspect of the story, namely Joseph's residence in Egypt. Other aspects, such as family relations, the relationship between the brothers, or the connection to the exodus will only be mentioned in passing.

\section{Joseph}

Before we turn our attention to the subject of Joseph in Egypt, we must first ask: who or what is Joseph? The name, which in Gen 30:24 is correctly interpreted from the situation of the birth as "he (Yhwh) may add," is rare in the pre-exilic onomasticon. Unlike the names of Joseph's ancestors, Abraham, Isaac, and Jacob, and also unlike the name Moses, it is, however, documented epigraphically at least once in pre-exilic times, namely in a bulla found in Jerusalem dating from the seventh century всE. The Hebrew inscription reads: לסאל בן יסף "to the S'L son of Joseph."1 It is not found in the onomasticon of Al-Yahudu and Elephantine, which takes us to Babylonian and Persian times. In Romano-Hellenistic times the name was quite common and documented many times both epigraphically as well as in the literature, such as in dedicatory inscriptions at the sanctuary on

\footnotetext{
${ }^{1}$ W. RöLlig, "Siegel und Gewichte," in Materialien zur althebräischen Morphologie, Vol. II/2 of Handbuch der Althebräischen Epigraphik (ed. J. Renz and W. Röllig; Darmstadt: WBG, 2003), 81-439, here 323, n. 15.1 .
} 
Mount Garizim (in both forms יסוסף יהוסף), and in a (lost) Aramaic inscription, dated to the $23^{\text {rd }}$ March 252 BCE, which was transcribed and published by M. Lidzbarski in 1927. ${ }^{3}$ The name is also attested in Maccabees and Judith. ${ }^{4}$ Despite the extremely sparse testimony in ancient times, we can still conclude that we are dealing with a common Hebrew personal name, which perhaps only became more widespread in later times.

In the Hebrew Bible, the situation is more complex since the name of Joseph is more than a personal name. Apart from the Joseph in the Joseph story the name is found almost exclusively in later, post-exilic texts as a name for individuals. ${ }^{5}$ Otherwise, it always stands for a collective, the "tribe of Joseph," the "sons of Joseph" Ephraim and Manasseh, as well as the "House of Joseph," which includes both the tribes of Ephraim and Manasseh and encompasses the entire northern kingdom of Israel, ${ }^{6}$ as well as finally, alongside "Jacob," all of Israel. ${ }^{7}$

In the Joseph story, Joseph is one of twelve sons of father Jacob-Israel - Reuben, Simeon, Benjamin, and Judah are also mentioned by name - and is the father of Ephraim and Manasseh. This means that here he primarily represents the "tribe of Joseph" and the tribal groups Ephraim and Manasseh arising from it. In opposition to Judah and Benjamin, this also implies the role as progenitor of the "House of Joseph," i. e., the northern kingdom of Israel. As an individual Joseph acts only in the role of a courtier in Gen 39-41.

When, in the following, we are enquiring about a possible historical context for Joseph in Egypt, we are thus enquiring about the residence in Egypt of the representative of a collective - the tribe of Joseph, the tribes of Ephraim and Manasseh, the northern kingdom of Israel. Only in chapters 39-41 of the book of Genesis are we concerned with the historical context in which a person of Hebrew birth (Israelite or Judean) enjoys an unprecedented career at the court of Egyptian Pharaoh.

${ }^{2}$ Y. Magen et al. (ed.), The Aramaic, Hebrew and Samaritan Inscriptions, Vol. 1 of Mount Gerizim Excavations (JSP 2; Jerusalem: Staff Officer of Archaeology - Civil Administration of Judea and Samaria, Israel Antiquities Authority, 2004), 26.265.

${ }^{3}$ See B. Porten and A. YArdeni (ed.), Ostraca \& Assorted Inscriptions, Vol. 4 of Textbook of Aramaic Documents from Ancient Egypt (The Hebrew University Department of the History of the Jewish People, Texts and Studies for Students; Winona Lake, IN: Eisenbrauns, 1999), 205 D8.13.

${ }^{4} 1$ Macc 5:18, 56, 60; 2 Macc 8:22; Jdt 8:1.

${ }^{5}$ Num 13:7; 1 Chr 25:2, 9; Ezra 10:42; Neh 12:14.

${ }^{6}$ See Josh 17:17; Ezek 37:16, 19; Zech 10:6.

${ }^{7}$ Ps 77:16; 81:5f. 


\section{Israel in Egypt (Gen 37-50)}

I will begin with the final shape of the Joseph story in Genesis 37-50, in which Joseph represents one of the twelve tribes of Israel, and at the end all of Israel moves to Egypt, from where, in the book of Exodus, it moves out again. Finding a possible historical anchor point for this version of the Joseph story proves to be the most difficult task.

If we want to date the narrative in the place to which it is assigned in the biblical history, in other words between Patriarchs and Exodus, then we have to refer to the various Egyptian witnesses from Asian peoples, in particular the Shasu and 'Apiru, who wandered back and forth between Palestine and Egypt at the end of the second millennium BCE. ${ }^{8}$ But since these witnesses make no mention of whole ethnicities crossing the borders, they cannot carry the burden of proof. In addition, they are contradicted by the oldest documentation of the name "Israel" which is found in the Merneptah Stele dated around 1200 BCE. 9 This has a distinct ethnic group in mind, that at this point of time is not found wandering the road between Palestine and Egypt, nor residing in Egypt, but is settled somewhere in middle-Palestine. We cannot make use of the Merneptah Stele either for Joseph in Egypt or for "Israel" in the Exodus narrative. We could perhaps argue that this "Israel" is identical with Joseph's father, Jacob, who is named "Israel" in the oldest version of the Joseph story, which, of course, would presuppose the renaming of Jacob in "Israel" in Gen 32. He must have been in Egypt with his entire clan earlier and then returned to Palestine. But this assumption is based solely on a merging and harmonisation of epigraphical and literary (biblical) sources and is highly unlikely. On the other hand, there are absolutely no grounds for a literary fiction of an eisodos and an exodus of the Israelites at the end of the second millennium $\mathrm{BCE}$.

For this reason, scholars have moved down some centuries and dated the Joseph story either in the time of Solomon ${ }^{10}$ or in the period of the splitting of the united monarchy under Rehoboam and Jeroboam I. ${ }^{11}$ According to this

${ }^{8}$ See M. Weippert, Historisches Textbuch zum Alten Testament (GAT 10; Göttingen: Vandenhoeck \& Ruprecht, 2010), 171-173.179-198.

${ }^{9}$ Weippert, Textbuch (see n. 8), 168-171; the full text (in German translation) is to be found in U. Kaplony-Heckel, "Ägyptische Historische Texte," in Rechts- und Wirtschaftsurkunden Historisch-chronologische Texte, Vol. I/6 of Texte aus der Umwelt des Alten Testaments (ed. D. Conrad et al.; Gütersloh: Gütersloher Verlagshaus, 1985), 544-552.

${ }^{10}$ G. von Rad, Das Erste Buch Mose: Genesis (12th ed.; ATD 2/4; Göttingen: Vandenhoeck \& Ruprecht, 1987), 357-358; see also IDEM, "Josephsgeschichte und ältere Chokma," in Gesammelte Studien zum Alten Testament (4th ed.; ed. G. von Rad; TB 8; München: Kaiser, 1958), 272-280; IDEM, "Die Josephsgeschichte," in Gottes Wirken in Israel. Vorträge zum Alten Testament (ed. O.H. Steck; Neukirchen-Vluyn: Neukirchener Verlag, 1974), 22-41.

${ }^{11}$ F. CRÜSEMAnN, Widerstand gegen das Königtum: Die antiköniglichen Texte des Alten Testaments und der Kampf um den frühen israelitischen Staat (WMANT 49; Neukirchen-Vluyn: Neukirchener Verlag, 1978); W. Dietrich, Die Josephserzählung als Novelle und Geschichts- 
theory, there is historical evidence in the temporary flight to Egypt of Jeroboam I, an Ephraimite and overseer of corvée labour in the "House of Joseph" (1 Kgs 11:40, 12:2). Like Hadad the Edomite before him (1 Kgs 11:17f) Jeroboam found refuge in Egypt with Pharaoh Shishaq (Shoshenq I) and returned after the death of Solomon to become king over the northern kingdom of Israel, the "House of Joseph." The epigraphically testified campaign of Shoshenq I to Palestine in $925 \mathrm{BCE}$ is readily associated with this event. ${ }^{12}$ All the more so because it is stated in 1 Kgs 14:25 that Shoshenq (spelled in two different ways, Qere: Shishaq, Ketiv: Shwshaq) attacked and robbed Jerusalem, which, however, is not confirmed by Pharaonic sources. Some scholars find this political situation reflected in the story of Joseph. The dreams of Joseph in Gen 37 suggest that they are dealing with questions of political dominance: according to this argument, the special role of Joseph (Ephraim and Manasseh, Jeroboam's country of origin), Benjamin (the home country of Saul), and Judah (the territory of the Davidic dynasty) best fits the situation at the splitting of the united monarchy under Rehoboam and Jeroboam I.

However, on closer examination, this argument does not make sense for a number of reasons. To begin with, the historical reconstruction is by no means certain. The news in $1 \mathrm{Kgs} 11-14$ is both meagre and unreliable. Jeroboam may indeed have once sought refuge in Egypt, but we do not know anything more about it. Furthermore, scholarship has dismissed more or less the idea of a Davidic-Solomonic empire and an outright splitting of this empire under Rehoboam and Jeroboam I. The opposition of "Joseph" (the northern territories of Israel) and Judah with Benjamin in the middle characterises the entire period of monarchy to $722 \mathrm{BCE}$, and certainly the time that follows, in which first "Joseph" (Samaria) and then Judah lost their sovereignty and both became rival provinces courting the favour of the respective foreign powers. Whether Shoshenq's Palestinian campaign really took place on Jeroboam's behalf and included Judah at all is more than questionable.

Secondly, literary evidence also speaks against a dating in the early (or later) monarchy. Most of the evidence that can be found in 1 Kgs 11-14, not least the polemic against the golden calves, which attributes the deliverance from Egypt to Jeroboam, is the result of Deuteronomistic and post-Deuteronomistic redaction and is therefore to be dated much later. ${ }^{13}$

schreibung: Zugleich ein Beitrag zur Pentateuchfrage (BThSt 14; Neukirchen: Neukirchener Verlag, 1989).

${ }^{12}$ For the textual evidence for Shoshenq's campaign, see WeIppert, Textbuch (see n. 8), 228-241.

${ }^{13}$ See R. G. Kratz, The Composition of the Narrative Books of the Old Testament (London: T\&T Clark, 2005), 165; German original version: Die Komposition der erzählenden Bücher des Alten Testaments (Göttingen: Vandenhoeck \& Ruprecht, 2000), $168 \mathrm{f}$. 
Finally, the narrative set-up within the Joseph story, such as the role of the other brothers or tribes (namely Ruben and Simeon), Joseph's political activities in and for Egypt or Joseph's supremacy over Judah and the other brothers, also do not comply with the assertion that the Joseph story should be read as a kind of political allegory of the power relations under Rehoboam and Jeroboam I. Erhard Blum has already objected to this and modified the thesis along the lines that the Joseph story should be seen on the one hand as a conceptual, but not literary, bridge between Patriarchs and Exodus and, on the other hand, more generally, as a desire to represent the supremacy of the "Joseph" kingdom over Judah, a position that it has taken many times in the course of the ninth and eighth centuries BCE history since Omri. As place and date of origin of the story he therefore suggests the vicinity of the northern Israelite court in the eighth century BCE. ${ }^{14}$

It seems to me that in pointing out the bridge between the Patriarchs and Exodus Blum has indeed offered the most appropriate solution, especially to the second part of the Joseph story in Gen 46-50. But if this is the case, then dating depends not least on when the two formerly independent traditions of the patriarchal history and the Exodus narrative merged. Also, the interpretation which stresses the status of the "Joseph" kingdom in "Israel" in general seems to me to be highly appropriate, although this issue is not restricted to the era of the two kingdoms, but could also have been adopted later, to clarify the relationship of the province of Samaria to the kingdom or the later province of Judah, respectively. We cannot simply deduce the date of origin from the content or the assumed intention of a biblical narrative. As far as the intention is concerned, it is an open question whether the Joseph story is in keeping with the official reasons of state of one of the two kingdoms or - in contrary - is targeting commonly accepted ideas in Israel and Judah. ${ }^{15}$ Above all, however, it is those aspects of the story which cannot be easily explained by the bridging function in the (biblical) sacred history of the people of Israel, or which even contradict this function, such as the stable long-term existence and traditional governing activities of Joseph in Egypt, which dissuade us from dating the Joseph story in the pre-exilic monarchic times.

\footnotetext{
${ }^{14}$ E. Blum, Die Komposition der Vätergeschichte (WMANT 57; Neukirchen: Neukirchener Verlag, 1984), 234-244.

${ }^{15}$ On the necessary distinction between the historical situation and the specific views of the biblical narrative dealing with this situation, see R. G. Kratz, Historical and Biblical Israel: The History, Tradition, and Archives of Israel and Judah (Oxford: Oxford University Press, 2015); German original version: Historisches und biblisches Israel: Drei Überblicke zum Alten Testament (2nd ed.; Tübingen: Mohr Siebeck, 2017).
} 


\section{Joseph is Alive (Gen 37-45)}

This now brings me to the first part of the Joseph story in Gen 37-45, in which, according to the analysis of Franziska Ede, we can identify an older version of the Joseph story. ${ }^{16}$ This version also deals with Joseph and his brothers, and thus with representatives of the people of Jacob-Israel, which stands for the northern kingdom. The main point of this version is that Joseph, sold by his brothers into Egypt and declared dead, is alive and carving out a career in Egypt. The suspense in Gen 37 is resolved with the reunion of the brothers and the message to JacobIsrael that Joseph is not dead but alive. Only, he is not living with his family in the same country, but in Egypt. No-one at this point seems to be considering an eisodos or exodus of the people of Israel.

Likewise, finding a possible concrete historical anchor point for this point of the story is not easy. However, we can at least say that the older version of the Joseph story in Gen 37-45 presupposes a historical situation in which large sections of the people of Israel, in particular those from the North, are living in Egypt. We have some, but not many, testimonies and literary reflections supporting this: a comment in the Letter of Aristeas (13), according to which Jews were sent to Egypt to serve in the army of Pharaoh Psammetik (it is not clear whether I or II), which takes us to the early sixth century вСЕ. The Jeremiah narratives report the flight of many Judeans to Egypt immediately after the conquest of Jerusalem by Nebuchadnezzar and following the murder of the governor Gedaliah (Jer 41-44). This, too, indicates the sixth century вСE. Both witnesses could shed light on the pre-history of the well-documented military colony on Elephantine, which, according to the evidence of papyri, already existed under Cambyses and survived up to the time under Darius II around $400 \mathrm{BCE}$, after which we lose trace. Numerous sources exist for the Hellenistic period and I need only to mention Alexandria and Leontopolis.

Thus, we can assume a Jewish diaspora in Egypt since the sixth century BCE. However, since the northern kingdom of Israel no longer existed at this time, it seems likely that this diaspora consisted mainly of Judeans not Israelites. This assumption is confirmed by the colonists on Elephantine, who referred to themselves as "Judeans" or "Arameans." ${ }^{17}$ On the other hand, there is also evidence of numerous Samarian Yhwh-worshippers in the Egyptian diaspora in the Hellenistic period. Also, the settlers on Elephantine maintained contact not only to moth-

${ }^{16}$ F. EDE, Die Josefsgeschichte. Literarkritische und redaktionsgeschichtliche Untersuchungen zur Entstehung von Gen 37-50 (BZAW 485; Berlin: Walter de Gruyter, 2016).

${ }^{17}$ On this, see R.G. Kratz, "Arameans and Judaeans: Ethnography and Identity at Elephantine," in Israel in Egypt: The Land of Egypt as Concept and Reality for Jews in Antiquity and the Early Medevial Period (ed. A. Salvesen et al.; Leiden: Brill, 2020), 56-85. German version: IDEM, "Aramäer und Judäer: Zur Ethnographie Elephantines in achämenidischer Zeit," in Persische Reichspolitik und lokale Heiligtümer (ed. R. Achenbach; BZAR 25; Wiesbaden: Harrassowitz, 2019), 163-184. 
erland Judah, but also to the province of Samaria. From this we may perhaps be able to assume that also in the pre-Hellenistic period there were already Yhwhworshippers from the province of Samaria among the members of the diaspora in Egypt. In a biblical perspective, Judeans and Samarians could have been identified with "Israelites" from the Northern region, the "House of Joseph."

Against this background, we can read the older version of the Joseph story in Genesis $37-45$ as a literary reflection on the Samarian-Judean diaspora in Egypt, which - perhaps from the Samarian, but perhaps also from the Judean, anti-Samarian perspective - was identified with the former Northern Kingdom and thus was regarded as the legitimate part of "Israel." For the author, Joseph did not continue to live in the province of Samaria, but in the Egyptian diaspora. That this part of "Israel" was given precedence over Judah (and the other brothers) is surprising but may reflect a view that predominates in other parts of the Hebrew Bible, especially in Jeremiah and in the book of Ezekiel regarding the stance of the (first) Babylonian Golah towards those that remained in the country and those that emigrated to Egypt. I will come back to this point again later in section 5 .

It is almost as impossible to detect a concrete historical anchor point in the history of the Jewish diaspora in Egypt for this view of things, as it is for the esteem in which the Jewish exiles were held in the history of the Babylonian Golah. As the texts of Al-Yahudu have shown recently, the Judean exiles in Babylon had as much or as little to do with the biblical view of the Babylonian Golah as the Samarian-Judean diaspora in Egypt - according to the authentic, epigraphic sources such as the Elephantine papyri and others - has with the image of Joseph in the Joseph story. ${ }^{18}$ In both cases we are dealing with literary (biblical) constructions, which take historical circumstances, here the existence of a Jewish diaspora in Babylon and Egypt, as the subject-matter on which to give a contemporary and, at the same time, interest-oriented form to the biblical ideal of the people of "Israel." One possibility for the time frame is the (outgoing) Babylonian, Persian or early Hellenist eras, in which the role of the Babylonian and Egyptian diaspora increasingly became the subject of biblical and parabiblical literature. Based on the relative chronology in the stratification of the Pentateuch, I suspect the outgoing Babylonian or Persian era for the older version of the Joseph story and the subsequent elaboration of the story as a bridge between the Patriarchs and Exodus.

\footnotetext{
${ }^{18}$ On the situation at Elephantine and Al-Yahudu, see Kratz, Israel (see n. 15), 137-153 (German version 186-213), with further references to the relevant editions and secondary literature.
} 


\section{Joseph at the Court of Pharaoh}

If we take a closer look at Gen 39-41, we can confirm this later dating. As Rüdiger Lux and Franziska Ede have shown, the Joseph story does not exist outside the narrative horizon of the patriarchal history in Gen 12-36 - whether as a literary link or as a conceptual one. ${ }^{19}$ It is all the more striking that at the centre of the older version of this additional "patriarchal story" in Gen 37-45 lies neither the people of Israel nor the tribe to which Joseph belongs and which he represents, but the fate of the Hebrew Joseph in the foreign country of Egypt where he was sold to by his brothers. The subject is taken up again in a later passage of the story in Gen 47 and developed further.

If we turn our attention to this feature of the story, then the question of historical context is focussed on the situation and fate of one Hebrew individual in Egypt. Such a situation could, theoretically, have occurred at any period of time. If we take into consideration the testimonies of the Asians and, in particular, the Israelites or Judeans in Egypt to which we referred earlier, then the time period ranges from the late second into the late first millennium $\mathrm{BCE}$, in other words, over the entire history of ancient Israel.

We can, however, restrict this period to the second half of the $1^{\text {st }}$ millennium on the basis of the story's genre. Its substance around Gen 39-41 (and 47) carries typical features of a court tale. We are familiar with these features from the Aramaic Ahiqar, the stories about Daniel, the book of Esther, and the book of Tobit, all of which deal with the fate of a foreigner (Aramean, Israelite or Judean) at a foreign court. The story of Sinuhe relates a reverse case of an Egyptian among Canaanites in Palestine. ${ }^{20}$ We are also able to cite an Egyptian parallel, the tale of two brothers, for the story of seduction in Gen $39 .{ }^{21}$

What do these parallels contribute to the dating of the Joseph story? The story of Sinuhe is an exception and originated in the early second millennium BCE; the story of Ahiqar reflects on the circumstances of the Neo-Assyrian empire in the seventh century ВСЕ but was found in the vicinity of the Jewish colony on Elephantine, which leads us into the Persian era around 400 BCE. Biblical parallels of court tales (Daniel, Esther, Tobit) also originated in the Persian or Hellenistic eras, even if they reflect older (Assyrian, Babylonian and Persian) circumstances. Unlike the Sinuhe and Ahiqar stories, biblical court tales are also always stories of diaspora, that either presuppose the downfall of Samaria and the Assyrian

${ }^{19}$ R. Lux, Josef: Der Auserwählte unter seinen Brüdern (Biblische Gestalten 1; Leipzig: Evangelische Verlagsanstalt, 2001); EDE, Josefsgeschichte (see n. 16), and her contribution to this volume.

${ }^{20}$ See Weippert, Textbuch (see n. 8), 51-62.

${ }^{21}$ C. Peust, "Das Zweibrüdermärchen," in Ergänzungslieferung, Supplementary Vol. of Texte aus der Umwelt des Alten Testaments (ed. M. Dietrich et al.; Gütersloh: Gütersloher Verlagshaus, 2001), 147-165. 
exile (according to Tobit, where also the Ahiqar story is adopted), or the downfall of Jerusalem and the Babylonian exile (according to Daniel and Esther). For this reason, Arndt Meinhold classifies the Joseph story in the genre of "diaspora novellas," with the difference that Joseph is not set in the Assyrian, Babylonian or Persian diasporas, but in the Egyptian. ${ }^{22}$

Even if the classification as a "diaspora novella" certainly does not fit the entire Joseph story, it is apt for chapters Gen 39-41 (and 47) and means that we are once more in the Babylonian era at the earliest, but more likely in the Persian or Hellenistic eras. From these eras we have evidence not only of the existence of a Samarian-Judean diaspora in Egypt, but also of the possibility of individuals rising to key positions in Egypt or elsewhere under Persian or Ptolemaic rule. For substantiation, I need only recall the Zenon papyri and the role of the Tobiades, which can be traced back to a progenitor named Joseph, and the exiled High Priest Onias (III or IV), to whom, after his expulsion from Jerusalem, Ptolemy VI assigned the "land of the Onias" in Leontopolis for the construction of a temple and a military colony. ${ }^{23}$

Following this path, Horst Seebaß believes he has detected a concrete historical anchor point for the Egyptian career of Joseph in Gen $39-41 .^{24}$ He compares the Joseph story with the "Famine Stela" from the Sehel Island, south of Elephantine. This stela dates from the Ptolemaic period (the exact date is unclear). It describes a seven-year drought, caused by the non-flooding of the Nile, which was resolved through the assistance of the Khnum temple on Elephantine. With reference to the Egyptologist Dietrich Wildung, ${ }^{25}$ Seebaß dates the story of the famine stela (including the motif of the drought) back to the Persian era on the basis of traditional history and perceives a polemic created by the Khnum priests in Elephantine against the cultic centre of Philae. In the same milieu Seebaß locates Joseph's invention of resource management in Gen 41 and the story of the seduction in Gen 39, which was inserted secondarily. According to his hypothesis, both stories address anti-Jewish tendencies in the Egyptian population on Elephantine and were only later inserted into the - significantly older - Joseph story of the already combined sources J and E. But no matter how attractive the parallels and the historic combination with the Judeans on Elephantine may be, the evidence is insufficient to see here a historical anchor point for Joseph's career in Egypt in Genesis 39-41 (and 47). The only direct point of contact is the

${ }^{22}$ A. Meinhold, "Die Gattung der Josephsgeschichte und des Estherbuches: Diasporanovelle I," ZAW 87/3 (1975), 306-324; “II,” ZAW 88/1 (1976), 72-79.

${ }^{23}$ See Kratz, Israel (see n. 15), 39f.42 (German 49f.52f).

${ }^{24} \mathrm{H}$. Seebass, Geschichtliche Zeit und theonome Tradition in der Joseph-Erzählung (Gütersloh: Gütersloher Verlagshaus, 1978), 26-41.

${ }^{25}$ D. Wildung, Posthume Quellen über die Könige der ersten vier Dynastien, Vol. 1 of Die Rolle ägyptischer Könige im Bewusstsein ihrer Nachwelt (MÄSt 17; Berlin: Bruno Hessling, 1969), 85-91. 
seven-year famine, whose mention is apparently unique in Egyptian literature. Everything else is based on pure, if not to say idle, speculation.

\section{Why Joseph in Egypt?}

Now that I have, with great regret, had to disappoint not only the editors of this volume, but also its readers because I can say almost nothing about the historical background of the Joseph story in the Egyptian diaspora, I would however like to close by at least presenting an idea on the possible reason for the emergence of the Joseph story. It is no more than an idea or an observation, but one that might at least be worthy of a mention and perhaps further consideration.

If we read the history of the Jews as a diaspora novella from the post-exilic period, two features are surprising: one is the choice of Joseph as the representative of the northern tribes and kingdom, and the second is the choice of Egypt as the diaspora's location. In all other diaspora novellas, it is either all the ten tribes of the north which are displaced to Assyria (Tobit), or the Judeans, who live in the Babylonian or Persian diaspora (Daniel, Esther). And so, the question arises: why Joseph, and why Egypt?

I have no ready answer and certainly no historical explanation for this phenomenon. But perhaps there is no historical explanation, but only a clue in the biblical tradition for a literary construction. Following the examination of the connecting points to the patriarchal history by Franziska Ede,${ }^{26}$ I would like to add another possible external impulse: the narratives of Jeremiah in Jer 36-45.

As Karl-Friedrich Pohlmann has shown, the Jeremiah narratives represent a Babylon-friendly and Golah-oriented stance. ${ }^{27}$ They are about life and death: all those who submit to Nebuchadnezzar and Babylon will live, all those who rise up against Babylon or flee to Egypt will perish completely. Nowhere else do those who move to Egypt come off as badly as here. In ch. 42 Jeremiah prays for the people of Judah in the land and receives the instruction from God that, under no circumstances, they should flee to Egypt; and in ch. 43-44 Jeremiah turns to Egypt and the Egyptian Golah and prophesises the total demise of both. The polemic is undoubtedly for contemporary and political reasons, but here it is ideologically charged. The position is not only in alignment with the programme of the Golah-oriented redaction in ch. 24, but also with the dispute between Hananiah and Jeremiah in ch. 27-28 and the letter to the Babylonian Golah in ch. 29, who are advised to "seek the welfare of the city (of Babylon)."28

\footnotetext{
${ }^{26}$ See her contribution to this volume.

${ }^{27}$ K.-F. Pohlmann, Studien zum Jeremiabuch: Ein Beitrag zur Entstehung des Jeremiabuches (FRLANT 118; Göttingen: Vandenhoeck \& Ruprecht, 1978).

${ }^{28}$ See R.G. Kratz, Translatio imperii: Untersuchungen zu den aramäischen Danielerzählungen und ihrem theologiegeschichtlichen Umfeld (WMANT 63; Neukirchen-Vluyn: Neukir-
} 
If we read the older version of the Joseph story in Gen 37-45 against the background of the Jeremiah narratives, we almost get the impression that it is written as a refutation: Joseph is not dead, but alive, and he is in fact in Egypt where he seeks the welfare of the country in which he is residing.

But why Joseph? Here, too, there is an interesting, albeit very puzzling passage in the Jeremiah narratives. In Jer 41 it is reported how, after the murder of Gedaliah, 80 men from Shiloh and Samaria, in other words, from the north, came to Judah to mourn. They are ambushed by Ismael, the son of Nethaniah, a man of royal descent who had already slain Gedaliah. Most of the men are killed. Only ten men are spared because they promise to offer their stores to Ismael. Ismael then flees to the Ammonites, which distantly recalls the Tobiades, the remaining Judeans (including, most likely, the ten spared men from Shiloh and Samaria) are taken to Egypt by Johanan, son of Kareah. In whatever way we explain the strange passage in the context of Jeremiah, it is a clear indication that Samarians were suspected to be among the Judeans who migrated to Egypt. And the polemic against the cult of the "Queen of Heaven" in Jer 44 (and Jer 7) reminds us not only of Judah, but also of Samaria, as well as the religious circumstances in the Judean colony on Elephantine.

The relationship between the Joseph story and the Jeremiah narratives is little more than circumstantial evidence. I do not want to construct a historical context from it, but I do find it to be remarkable. Thus, the Joseph in the Joseph story is not only representing the former northern kingdom, but also the Yhwhworshippers in the province of Samaria, who are coming increasingly to our attention because of recent archaeological and epigraphic findings. The fact that Joseph as a representative of this group in opposition to Judah and Benjamin was the subject of theological reflection and literary production attested not least by the Joseph texts among the Dead Sea Scrolls (4Q371-373).

chener Verlag, 1991), 190-197. 



\title{
How "Persian" or "Hellenistic" is the Joseph Narrative?
}

\author{
Thomas Römer
}

There are very few things about which scholars agree in regard to the biblical story of Joseph in Gen 37-50. A majority would probably agree that the Joseph story is quite different from the foregoing narratives about Abraham, Isaac, and Jacob, and also that we have here an impressive piece of narrative art and storytelling, as pointed out by Gerhard von Rad but also by the Egyptologist Donald B. Redford: "No piece of prose elsewhere in the Bible can equal the literary standard attained by the Joseph story of Genesis 37-50."

But as soon as the question of the literary unity of the story arises, opinions diverge. ${ }^{2}$ Moreover, interpretive positions differ even further when one discusses the reconstruction of the original story and its date and historical setting.

\section{The Literary Coherence of the Joseph Narrative}

Every attentive reader of the book of Genesis notices the differences between the narrative about Joseph and the one about the patriarchs in Gen 12-36. Whereas the stories about Abraham, Isaac, Jacob, and their wives are patchworks of a sort, combining former independent narratives or smaller cycles, the narrative about Joseph and his brothers is a straightforward story, not a combination of former independent units. The theology is also quite different: whereas Abraham, Isaac, and Jacob receive divine speeches telling them what to do or informing them about future events, Joseph never enters in any direct communication with God. In the Joseph narrative, there is no cultic etiology, nor are Yhwh and 'elohim used interchangeably (with the exception of Gen 39). Differences with the Exodus have also been observed, most notably that in Genesis the Pharaoh is depicted positively and Egypt seen as a place of sojourn.

Von Rad was one of the first to highlight the literary unity of the Joseph story and its wisdom flair in contrast to the Patriarchal narratives. Although praising

\footnotetext{
${ }^{1}$ D. B. Redford, Egypt, Canaan, and Israel in Ancient Times (Princeton, NJ: Princeton University Press, 1993), 423.

${ }^{2}$ For an overview of the recent history of research see C. PAAP, Die Josephsgeschichte Genesis 37-50. Bestimmungen ihrer literarischen Gattung in der zweiten Hälfte des 20. Jahrhunderts (EHS.T 534; Frankfurt a.M. et al.: Peter Lang, 1994) and F.W. GolKA, "Genesis 37-50: Joseph Story or Israel-Joseph Story?," CBR 2/2 (2004), 153-177.
} 
the literary artistry of the Joseph story, he still postulated a J-version and an Eversion of the story that later redactors combined. ${ }^{3}$ This was due to a certain "Systemzwang," already acknowledged by Julius Wellhausen, who said that there must be a Yahwistic and an Elohistic strand to narrative, otherwise the whole Documentary theory would collapse. ${ }^{4}$ The separation of the Joseph-story into a Yahwistic and an Elohistic version still has its supporters even today, ${ }^{5}$ but no one ever succeeded in reconstructing two coherent independent narratives. ${ }^{6}$ First of all, the classical criterion of the Documentary hypothesis, namely the use of different divine names, does not work at all for this narrative (the tetragrammaton only appears in Gen 39).

Second, there are indeed many cases of “doublets" (e.g., Joseph's dreams, the dreams of the prisoners and Pharaoh's dreams all go by two; Joseph is taken to Egypt by the Ishmaelites and Midianites; the brothers travel to Egypt two times where they meet Joseph twice; twice Joseph is hiding something in his brothers' sacks, etc.).

Several times there are double interventions of Reuben and Judah, especially in Gen 37 in order to protect Joseph's life and later in order to convince Jacob to let Benjamin descend with them to Egypt. The Patriarch has two names, he is mostly called Jacob, but sometimes Israel. But some of these repetitions are part of the author's narrative strategy and are necessary for understanding the plot of the story, ${ }^{7}$ whereas other doublets could indeed be explained not by the

${ }^{3}$ G. von RAD, "Josephsgeschichte und ältere Chokmah" in Congress Volume. Copenhagen 1953 (VTSup 1; Leiden: Brill, 1953), 120-127; see also IDEM, Das erste Buch Mose. Genesis (9th ed.; ATD 2/4; Göttingen: Vandenhoeck \& Ruprecht, 1972), 283-284.

${ }^{4}$ J. Wellhausen, Die Composition des Hexateuchs und der historischen Bücher des Alten Testaments (4th ed.; Berlin: Reimer, 1963), 52: "es ist zu vermuten, dass dies Werk hier wie sont aus J und E zusammengesetzt sei; unsere früheren Ergebnissse drängen diese Annahme auf und würden erschüttert warden, wären sie nicht erweisbar". This quotation was recently reminded by J.L. Ska in his foreword to M. C. Genung, The Composition of Genesis 37 (FAT 95; Tübingen: Mohr Siebeck, 2017,) VIII.

${ }^{5}$ See for instance L. SснміDт, Literarische Studien zur Josefsgeschichte (BZAW 167; Berlin and New York: de Gruyter, 1986); L. RupperT, "Zur neueren Diskussion um die Joseferzählung in der Genesis," BZ.NF 33 (1989), 92-97; J.S. BADEN, The Composition of the Pentateuch: Renewing the Documentary Hypothesis (ABRL; New Haven, CT: Yale University Press, 2012), 34-44. See also H. Seebass, Genesis III: Josephgeschichte (37,1-50,26) (Neukirchen-Vluyn: Neukirchner Verlag, 2000), who however is much more cautious as some of his colleagues. He emphasizes that the Joseph story is "wegen ihrer formalen Geschlossenheit im Pentateuch singulär" (6) and admits an important post-priestly redaction (210-211).

${ }^{6}$ Despite the statement of B. J. Schwartz, "Compiler" (see n. 67).

${ }^{7}$ See already B. ЈАСов, Das erste Buch der Tora: Genesis (Berlin: Schocken Verlag, 1934), passim, who however rejects any diachronic analysis. Very influent was the essay of H. DonNER, Die literarische Gestalt der alttestamentlichen Josephsgeschichte (SHAW.PH 2; Heidelberg: Universitätsverlag Winter, 1976); cf also R.N. WhybraY, "The Joseph Story and Pentateuchal Criticism," VT 18 (1968), 522-528 and G.W. CoATs, "Redactional Unity in Genesis 37-50," JBL 93 (1974), 15-21. 
compilation of two parallel documents, but - contra Wellhausen - through a model of successive complementation.

\section{Reconstructing the Original Joseph Story}

There is some agreement about the assumption that ch. $38,46-48$, and 49 , are not an original part of the Joseph story. The case of Gen 38 is widely accepted. Gen 38 is a story about Judah, who, in contrast to the Joseph narrative, is already a quite old and married man. The tribal sentences in Gen 49 are originally unrelated to the Joseph narrative. ${ }^{8}$ Gen 46 and 48 are insertions, the aim of which is to strengthen the link with the foregoing Patriarchal narratives and to prepare the Exodus story. ${ }^{9}$ The passage where Joseph invents capitalism and makes the Egyptians into slaves of Pharaoh $(47: 13-26)$ is also an addition, ${ }^{10}$ because it does not fit well with the context of the Joseph narrative: it does not mention Joseph's brothers and contradicts Joseph's advice to Pharaoh as well as his actions in $41: 25-56^{*}$.

The story of Potiphar's wife in Gen 39 is probably also a case of (twofold) supplementation, as I have tried to show elsewhere. ${ }^{11}$ This is this only story in which the name of Yhwh appears. At the end of Gen 39 Joseph gains a prestigious

${ }^{8}$ J.-D. MACCHI, Israël et ses tribus selon Genèse 49 (OBO 171; Fribourg and Göttingen: Presses universitaires and Vandenhoeck \& Ruprecht, 1999), 235-243.

${ }^{9}$ See E. Blum, Die Komposition der Vätergeschichte (WMANT 57; Neukirchen-Vluyn: Neukirchener Verlag, 1984), 246-254. See also E. Blum and K. Weingart, "The Joseph Story: Diaspora Novella or North-Israelite Narrative," ZAW 129/4 (2017), 501-521, here 507-510.

${ }^{10} \mathrm{H}$. Seebass, Geschichtliche Zeit und theonome Tradition in der Joseph-Erzählung (Gütersloh: Gütersloher Verlagshaus, 1978), 58-61; P. WeIMAR, "Gen 47,13-26 - ein irritierender Abschnitt im Rahmen der Josefsgeschichte," in Auf dem Weg zur Endgestalt von Genesis bis II Regum: Festschrift für Hans-Christoph Schmitt zu seinem 65. Geburtstag (ed. M. Beck and U. Schorn; BZAW 370; Berlin and New York: Walter de Gruyter, 2006), 125-138. For this passage see below.

${ }^{11}$ T. Römer, "Joseph and the Egyptian Wife (Genesis 39): A Case of Double Supplementation," in Supplementation and the Study of the Hebrew Bible (ed. S. M. Olyan and J.L. Wright; BJS 361; Providence, RI: Brown Judaic Studies , 2018), 69-83. For the secondary character of Gen 39 see B.D. Eerdmans, Die Komposition der Genesis (Alttestamentliche Studien 1; Giessen: A. Töpelman, 1908), 66-67; D. B. Redford, A Study of the Biblical Story of Joseph (Genesis 3750) (VTSup 20; Leiden: Brill, 1970), 147; N. KeBeKUs, Die Joseferzählung: Literarkritische und redaktionsgeschichtliche Untersuchungen zu Genesis 37-50 (Münster: Waxmann, 1990), 31-45; K. D. LIsEWSKI, Studien zu Motiven und Themen zur Josefsgeschichte der Genesis (EHS.T 881; Bern et al.: Peter Lang, 2008), 321-324 speaks of a "Fremdkörper". Other authors envisage a revision of an older story in Gen 39: P. Weimar, “Jahwe aber ward mit Josef' (Gen 39,2). Eine Geschichte von programmatischer Bedeutung," in Studien zur Josefsgeschichte (SBA 44; Stuttgart: Katholisches Bibelwerk, 2008), 61-124; C. Levin, "Righteousness in the Joseph Story: Joseph Resists Seduction (Genesis 39)," in The Pentateuch (ed. T. B. Dozeman et al.; FAT 78; Tübingen: Mohr Siebeck, 2011), 225-240, here 229-230 reconstructs an original text in which Yhwh is not mentioned. 
position in prison, but in Gen 40 he is serving two prisoners. Moreover, the conclusion of this chapter is not completely satisfying from a narrative point of view, because the misdeed of Potiphar's wife remains undiscovered and unpunished. ${ }^{12}$ Perhaps, then, Gen 39 was an independent (Joseph?) story modeled on the Egyptian Tale of the Two Brothers that was inserted into the original story in two or three stages. ${ }^{13}$

Additionally, Gen 50:24-25 is a late passage that combines a Pentateuchal and a Hexateuchal redaction. V. 24 connects with Deut 34:4 with the theme of the oath to the Patriarchs and provides an overall frame for the Pentateuch. It also appears that v. 25 belongs to a Hexateuchal redaction introducing the motif of Joseph's bones that are buried in Josh 24:32. ${ }^{14}$

Finally, there is also the question of the "competition" between Reuben and Judah, the main characters and spokesmen among Joseph's brothers. This competition has led to the assumption that one should distinguish between a "Reuben version" and a "Judah version" in the Joseph narrative, or that that the original story contained only Reuben and was later revised with the introduction of Judah ${ }^{15}$ in order to present the Joseph narrative as a story showing the reconciliation between the North (Joseph) and the South (Judah). ${ }^{16}$ But yet another option is still possible: the Judah layer belonged to the original story, because his personal guarantee as well as his speech in Gen 44:18-34 are necessary for the scene of reconciliation in ch. $44 .{ }^{17}$ The Reuben layer would then have been added by a later redactor ${ }^{18}$ who wanted to clear all brothers of blame

${ }^{12}$ J.-L. SKA, Introduction à la lecture du Pentateuque: clés pour l'interprétation des cinq premiers livres de la Bible (trans. F. Vermorel; Le livre et le rouleau 5; Bruxelles: Éditions Lessius, 2000), 206-207.

${ }^{13}$ Römer, "Wife" (see n. 11); Redford, A Study of the Biblical Story of Joseph (see n. 11), 147; SKA, Introduction (see n. 12), 206-207.

${ }^{14}$ See Blum, Vätergeschichte (see n. 9), 255-257; T. RömER, Israels Väter: Untersuchungen zur Väterthematik im Deuteronomium und in der deuteronomistischen Tradition (OBO 99; Freiburg and Göttingen: Universitätsverlag and Vandenhoeck \& Ruprecht, 1990), 561-566; T. RÖMER and M.Z. Brettler, "Deuteronomy 34 and the Case for a Persian Hexateuch,” JBL 119 (2000), 401-419, here 410.

${ }^{15}$ W. Dietrich, Die Josephserzählung als Novelle und Geschichtsschreibung: Zugleich ein Beitrag zur Pentateuchfrage (BThSt 14; Neukirchen-Vluyn: Neukirchener Verlag, 1989), 20-22; KeBEKUs, Joseferzählung (see n. 11), 231-336, who distinguishes a Reuben basic layer, a Reuben redaction and a Judah redaction. See also MACCHI, Israël (see n. 8), 127-128 and SKA, Introduction (see n. 12), 207.

${ }^{16}$ For this interpretation see G. Fischer, "Die Josefsgeschichte als Modell für Versöhnung," in Studies in the Book of Genesis: Literature, Redaction and History (ed. A. Wénin; BEThL 155; Leuven: University Press and Peeters, 2001), 243-271, here 270-271.

${ }^{17}$ K. Schmid, "Die Josephsgeschichte im Pentateuch," in Abschied vom Jahwisten: Die Komposition des Hexateuch in der jüngsten Diskussion (ed. J.C. Gertz, et al.; BZAW 315; Berlin: Walter de Gruyter, 2002), 83-118, here 105.

${ }^{18}$ See especially H.-C. Schмiтt, Die nichtpriesterliche Josephsgeschichte: Ein Beitrag zur neuesten Pentateuchkritik (BZAW 154; Berlin: Walter de Gruyter, 1980), 26. 
by presenting a positive image of the firstborn. ${ }^{19}$ As several authors have noted, it is not easy to reconstruct an older story that contains only the interventions either of Reuben or of Judah. As an example, one may quote the latest diachronic analysis of Gen 37 by Franziska Ede and Matthew Genung. Ede postulates that the figure of Reuben was added later than Judah, ${ }^{20}$ whereas Genung defends the theory according to which the original narrative of Gen 37 contained only Reuben's proposal to throw Joseph into a well. ${ }^{21}$

This ongoing lack of consensus invites to explore an alternative hypothesis according to which the original narrative contained both characters, an assumption that does not exclude some revisions. ${ }^{22}$

One could perhaps explain the shift from Reuben to Judah in a way similar to Num 1-2. In Num 1-2, the census of Israel's tribes starts with the tribe of Reuben, the first-born, but, when it comes to the organization of the camp, the east side led by Judah is mentioned first, which is a subtle way to emphasize Judah's importance. ${ }^{23}$ The Joseph narrative may be crafted along similar lines: the author presupposes an audience familiar with the list of the twelve tribes or Jacob's twelve sons, according to which Reuben is the first-born. As first-born, he has to play an important role. Yet, the author also wanted to show the importance of Judah, who ends up becoming a more central figure than Reuben.

According to the previous analysis we can conclude that the original Joseph story culminated with the reconciliation of Joseph and his brothers, and that after ch. 45 we should imagine only a short notice about the descent of the father to Egypt and Joseph's death.

To summarize, we may construct the original Joseph narrative grosso modo as contained in Gen $37^{\star} ; 40-45^{\star} ; 24$ 46:28-33; 47:1-12; 50:1-11,14-21,26. There are certainly many more revisions and additions, but we will deal with some of those during our investigation.

\footnotetext{
${ }^{19}$ Schmid, "Die Josephsgeschichte im Pentateuch" (see n. 17), 105.

${ }^{20} \mathrm{~F}$. EDE, Die Josefsgeschichte: Literarkritische und redaktionsgeschichtliche Untersuchungen zur Entstehung von Gen 37-50 (BZAW 485; Berlin and Boston: Walter de Gruyter, 2016), 65-67.

${ }^{21}$ Genung, The Composition of Genesis 37 (see n. 4), 70-83.

${ }^{22}$ PAAP, Josephsgeschichte (see n. 2), 168-169 and in a detailed way K. WEIngart, Stämmevolk - Staatsvolk - Gottesvolk?: Studien zur Verwendung des Israel-Namens im Alten Testament (Tübingen: Mohr Siebeck, 2014), 247-251.

${ }^{23}$ See also D. T. Olson, The Death of the Old and the Birth of the New: The Framework of the Book of Numbers and the Pentateuch (BJS 71; Chico, CA: Scholars Press, 1985), 60-61.

${ }^{24}$ According to some authors as Dietrich, Novelle (see n. 15), 40; KebekUs, Joseferzählung (see n. 11), 149-152; R. G. Kratz, Die Komposition der erzählenden Bücher des Alten Testaments (Göttingen: Vandenhoeck \& Ruprecht, 2000), 281-286, Gen $45^{\star}$ would have been the end of the original narrative. However, Gen 45:5-8 prepares 50:18-21 Joseph's speech in 50:19-21 and is the necessary conclusion of Gen 37: Joseph's brothers are now falling down before him, but in a situation in which they respect his position.
} 


\section{Dating the Joseph Narrative and Explaining Its Northern Connections}

The different proposals for dating the Joseph narrative cover almost thousand years, spanning from the thirteenth century (Joseph Vergote) ${ }^{25}$ to the Seleucid period. ${ }^{26}$ This can give the impression that "anything goes," but here we should recall with Umberto Eco "the limits of interpretation." In his collection of essays, he emphasized that an interpretation is only tenable if it is confirmed by other passages of the text. If it is contradicted by other observations it must be corrected. ${ }^{27}$ That means that Vergote's idea that the original narrative arose in Mosaic times and von Rad's and others' theory of an origin in the "Solomonic enlightenment" 28 cannot stand in the light of internal and external evidence.

I have discussed these theories elsewhere ${ }^{29}$ and will myself restrict here to the question of a "Northern" origin of the Joseph narrative.

The name Joseph appears several times in the Hebrew Bible as a designation for the North; in a "neutral" way as "house of Joseph" in Judg 1:22-23,35; 2 Sam 19:20; $1 \mathrm{Kgs}$ 11:28; in prophetic oracles of destruction and rejection in Am 5:6,15; Obad 18; Ps 78:67; in postexilic announcements of restoration in Ezek 37:16,19; 47:13; 48:32; Ps 77:15. Thus, several scholars are in favor of a Northern origin for the Joseph narrative.

This is, among others, ${ }^{30}$ the case Erhard Blum ${ }^{31}$ and his student, Kristin Weingart, have made and developed..$^{32}$ Blum depends on Frank Crüsemann's idea, that the main theme of the Joseph story is dominion. ${ }^{33}$ The question of the

\footnotetext{
${ }^{25}$ J. Vergote, Joseph en Égypte: Genèse chap. 37-50 à la lumière des études égyptologiques récentes (OBL 3; Leuven: Peeters, 1959).

${ }^{26}$ B. J. Diebner, "Le roman de Joseph, ou Israël en Égypte: Un midrash post-exilique de la Tora," in Le livre de traverse: De l'exégèse biblique à l'anthropologie (ed. O. Abel and F. Smyth; Patrimoines; Paris: Cerf, 1992), 55-71 (he seems even to think of the Roman period); J.A. Sog GIN, "Notes on the Joseph Story," in Understanding Poets and Prophets: Essays in Honor of George Wishart Anderson (ed. A. G. Auld; JSOTSup 152; Sheffield: Sheffield Academic Press, 1993), 336349; A. Catastini, "Ancora sulla datazione della 'Storia di Guiseppe," Hen. 20 (1998), 208-224; A. KunZ, "Ägypten in der Perspektive Israels am Beispiel der Josefsgeschichte (Gen 37-50)," BZ 47 (2003), 206-229.

${ }^{27}$ U. Eco, The Limits of Interpretation (Advances in Semiotics; Bloomington and Indianapolis, IN: Indiana University Press), 1994.

${ }^{28}$ vON RAD, "Josephsgeschichte" (see n. 3), followed by Seebass, Zeit (see n. 10), 102."

${ }^{29}$ T. Römer, "The Joseph Story in the Book of Genesis: Pre-P or Post-P?," in The PostPriestly Pentateuch: New Perspectives on its Redactional Development and Theological Profiles (ed. F. Giuntoli and K. Schmid; FAT 101; Tübingen: Mohr Siebeck, 2015), 185-202.

${ }^{30}$ For other proposals to locate the Joseph Story in the North see Dietrich, Novelle (see n. 15); KebeKus, Joseferzählung (see n. 11).

${ }^{31}$ Blum, Vätergeschichte (see n. 9), 239-44.

32 Weingart, Stämmevolk (see n. 22). A Northern origin is also postulated by SKa, Introduction (see n. 12), 207.

${ }^{33}$ F. CRÜSemann, Der Widerstand gegen das Königtum: Die antiköniglichen Texte des Alten Testaments und der Kampf um den frühen israelitischen Staat (WMANT 49; Neukirchen-Vluyn:
} 
brothers in Gen 37:8 ("Are you indeed to reign over us? Are you indeed to have dominion over us?") thus indicates that the theme of the narrative is Joseph's kingdom in Israel. ${ }^{34}$ Weingart suggests that one should read the Joseph narrative as a "Ringen um Benjamin." ${ }^{5}$ The story insists on the close relation between Joseph and Benjamin: "Die auslösende Frage ist daher nicht, ob Benjamin zu Joseph gehört, sondern wie er zu Joseph kommt." ${ }^{36}$

The Joseph narrative should therefore be understood as "political propaganda" for the Israelite kingdom (when exactly?) because it shows that Benjamin belongs to Joseph/Israel. ${ }^{37}$ However, this kind of "historical allegory" is problematic. If one wants to read the story as a conflict about Benjamin, one could also and perhaps should think of the situation after 722 вСE when Benjamin came to Judah.

\section{Which Role for Benjamin}

One could then perhaps read Judah's defense of Benjamin as an indication that Benjamin belongs to Judah. ${ }^{38}$ Yet, in my view, a close reading of the Joseph story reveals a rather different role for Benjamin. The question is not at all whether he belongs to Israel or to Judah, but rather how the brothers will behave towards him. The author uses plot symmetry and constructs Benjamin as a "second Joseph:" 39 he becomes the new preferred son of Jacob, and he is also singled out by Joseph, who gives him a much bigger portion of food (43:34) but then accuses him to be a thief (44:1-13). In contrast to what the brothers did to Joseph, however, they accept Jacob's and Joseph's preferential treatment of Benjamin, and even stand in solidarity when the latter is accused by Joseph. This change of behavior leads then to the reconciliation described in Gen 45. The plot is therefore not about the destiny of Benjamin per se, but about the possible reconciliation of the whole family.

A Northern setting and a preexilic date for the Joseph story also fails to give a satisfying explanation for the forced descent of Joseph to Egypt and for the fact that Joseph stays there until his death. If Joseph's story is "political propaganda"

Neukirchener, 1978), 143-155. See also C. Westermann, Genesis 37-50, Vol. 3 of Genesis (BK I/3; Neukirchen-Vluyn: Neukirchener Verlag, 1982), 29-30.

${ }^{34}$ Blum, Vätergeschichte (see n. 9), 242; WeIngart, Stämmevolk (see n. 22), 245; Blum and WeIngart, “The Joseph Story” (see n. 9), 501-521; 518-519.

${ }^{35}$ Weingart, Stämmevolk (see n. 22), 252.

${ }^{36}$ Ibid., 254.

${ }^{37}$ Ibid., 262-266. See also Blum and Weingart, “The Joseph Story” (see n. 9).

${ }^{38}$ Y. Levin, "Joseph, Judah and the 'Benjamin Conundrum', 'ZAW 116/2 (2004), 223-241, here 239-240.

${ }^{39}$ J. LAMBERT, Le Dieu distribué: Une anthologie comparée des monothéismes (Patrimoines; Paris: Cerf, 1995), 51. 
(K. Weingart) for the Northern kingdom, why would one locate the story in Egypt and leave the hero in this land at the end of the story?

For Weingart, it shows that the Joseph narrative was conceived from the very beginning as a "Zwischenstück zwischen Erzelternerzählungen und Exodus," an assumption difficult to maintain. ${ }^{41}$ There is no doubt that the author of the narrative is keen to give details about Egyptian names and customs, and even attributes a cup of divination to Joseph (44:5). But if narrative necessity is the only reason for the location of the story in Egypt, why should the author tell us that Joseph married the daughter of an Egyptian priest (41:45), so that his sons, Manasseh and Ephraim, are half Egyptian (41:50-52)? Or why would he relate the fact that Joseph was embalmed like an Egyptian high officer after his death (50:3)?

\section{A Late (Post-P) Story}

There are internal and external reasons for favoring a late date of the Joseph narrative. As often observed, there are no allusions to the Joseph narrative in the Hebrew Bible, except Ps 105, which is definitely a psalm from the Persian or Hellenistic period. ${ }^{42}$ The burying of Joseph's bones in Josh 24:32 belongs to a Persian period Hexateucal redaction, and the mention of Joseph in Exod 1:6-7 belongs to a late ( $\mathrm{P}$ or post- $\mathrm{P}$ ) redaction that aims at creating a link between the Joseph narrative and the exodus story.

It is often argued that the Joseph-story must be earlier than P, but as I have showed elsewhere the priestly document or priestly strata do not presuppose the Joseph story. ${ }^{43}$ If one takes those passages which are traditionally assigned to $\mathrm{P}$ (Gen 37:1-2a; 41:46a; 46:6-744; 47:27b-28; 48:3-6; 49.1a,28b-33; 50:12-13; Exod $1: 1-5,7)^{45}$ one has to admit that they do not constitute by any means a coherent

${ }^{40}$ Weingart, Stämmevolk (see n. 22), 265.

${ }^{41}$ As mentioned above, E. Blum and others have demonstrated, that texts like Gen 48 and 50:24-25 were inserted into the Joseph narrative in order integrate it story into the broader context of the Penta- or Hexateuch: this is an indication that the original Joseph story was not intended as a bridge between the Patriarchs and the Exodus.

${ }^{42}$ S. RAmond, Les leçons et les énigmes du passé: une exégèse intra-biblique des psaumes historiques (BZAW 459; Berlin: Walter de Gruyter, 2014), 155-159.

${ }^{43}$ See already Römer and Brettler, "Deuteronomy 34" (see n. 14), and in a more detailed way Römer, "Joseph Story in Genesis" (see n. 29); see further ScHmid, "Die Josephsgeschichte im Pentateuch" (see n. 17); Genung, The Composition of Genesis 37 (see n. 4), 137-168 and 208.

44 The list in 46:8-27 is generally considered as $\mathrm{P}^{\mathrm{s}}$.

45 This reconstruction is inspired by the synopsis of P. P. Jenson, Graded Holiness: A Key to the Priestly Conception of the World (JSOTSup 106; Sheffield: JSOT Press, 1992), 221-222, who compares the reconstruction of P by Martin Noth, Karl Elliger, Norbert Lohfink, Peter Weimar, and Heinrich Holzinger. See similarly ScHмid, "Die Josephsgeschichte im Pentateuch" (see n. 17), 92, with more literature, and R. J. Lux, Der Auserwählte unter seinen Brüdern (Biblische Gestalten 1; Leipzig: Evangelische Verlagsanstalt, 2001), 150-151, who adds especially 47:5-11*. A different approach is taken by L. SCHMIDT, "Die Priesterschrift in der Josefsgeschichte (Gen 37; 
text. This is a very different situation compared to the $\mathrm{P}$ version of the Abraham and Jacob narratives. So, why would $\mathrm{P}$ have acted in such a different way with the Joseph-story?

The best explanation is that $\mathrm{P}$ did not know the Joseph story or at least not refer to it. For P, the link between the time of the Patriarchs and the Exodus-narrative was made by the descent of 70 members of Jacob's family to Egypt, where they then became a numerous people.

This matches the descent of Jacob and his family mentioned in Deut 26:5; Num 20:15; 1 Sam 12:8, or Ezek 20:5. In these texts, the settlement of the ancestors in Egypt is not related to a Joseph narrative. That means that the priestly texts of the end of Genesis and the beginning of Exodus (37:1; 46:6-7; 47:27b-28; 49:1a, 28b-33, 50:12-13; Exod 1:1-5a,7,13) do not show an awareness of a Joseph narrative.

\section{A Diaspora Novella}

It is easiest to explain the attention given to describing the Egyptian integration and career of Joseph if one assumes that the Joseph narrative is a "diaspora novella" and was composed as a story reflecting on the possibilities of a life outside of the land. Arndt Meinhold was one of the firsts to suggest this theor ${ }^{46}$ and to point out the structural parallels in the stories of Esth, Dan 2-6 and Gen 37-50*

The theology and the exclusive use of 'elohim ${ }^{47}$ also point to a late date for the Joseph story. Interestingly, the narrator never suggests any divine intervention. All comments about God's involvement appear on the lips of the protagonists (Joseph, Jacob, Pharaoh, the brothers). Therefore, one can read the story in a totally "profane" way, or accept the theological interpretations given by Joseph or other actors. This brings the Joseph story close to the massoretic form of the book of Esther, which is also very discreet about divine intervention. ${ }^{48}$ Finally, Joseph and Pharaoh have no theological confrontation when speaking about

39-50)," in Auf dem Weg zur Endgestalt von Genesis bis II Regum: Festschrift für Hans-Christoph Schmitt zu seinem 65. Geburtstag (ed. M. Beck and U. Schorn; BZAW 370; Berlin and New York: Walter de Gruyter, 2006), 111-123 and A. Graupner, Der Elohist: Gegenwart und Wirksamkeit des transzendenten Gottes in der Geschichte (WMANT 97; Neukirchen-Vluyn: Neukirchener Verlag, 2002), 316-379, who add important passages in order to reconstruct a more or less coherent narration without giving any clear reasons why the passages should be attributed to P. This looks very much as a "Systemzwang"; see also the critical remarks of ScHmid, "Die Josephsgeschichte im Pentateuch" (see n. 17), 92, n. 54.

${ }^{46}$ A. Meinhold, "Die Gattung der Josephsgeschichte und des Estherbuches: Diasporanovelle I \& II," ZAW 87- 88 (1975-1976), 306-324; 72-93.

${ }^{47}$ If one accepts the hypotheses that Gen $39^{\star}$ did not belong to the original Joseph story (see above).

${ }^{48}$ There is a major difference with the story of David's ascension to the throne in which the narrator insets comments that "Yhwh was with David" (comparable to Gen 39). 
God. In Gen 41:25-45, Josephs interprets the king's dreams by stating that "God has revealed to Pharaoh what he is about to do" (v. 25), and Pharaoh answers to Joseph that "God has shown you this" (v. 39).

The theology of the Joseph narrative could be labeled as "anti-deuteronomistic:" mixed marriages are accepted, as are contacts with "pagan" religions and integration into the Egyptian culture. In contrast to the book of Esther, there is no emphasis on the danger that can occur in a diaspora situation, although there are some hints about the fact that integration cannot or should not be complete. One sees it, for example, in the fact that Joseph's family is settled in the land of Goshen, ${ }^{49}$ separated from the Egyptians, ${ }^{50}$ and also in the note of 43:32: "They served him by himself, and them by themselves, and the Egyptians who ate with him by themselves, because the Egyptians could not eat with the Hebrews, for that is an abomination to the Egyptians." This note has sometimes been compared to Herodotus' information about the segregation of the Egyptians from the Greeks: "This is the reason why no native of Egypt, whether man or woman, will give a Greek a kiss, or use the knife of a Greek, or his spit, or his cauldron, or taste the flesh of an ox, known to be pure, if it has been cut with a Greek knife." (Histories II,41). ${ }^{51}$

The situation described there reflects the Diaspora situation: Joseph, representing the Diaspora finds himself between his brothers and the Egyptians. Do we have here an allusion to Egyptian xenophobia, ${ }^{52}$ or even the beginning of some anti-Judean resentments in Egypt? ${ }^{53}$ The same expression, "abomination (toeba) for the Egyptians", appears in the Hebrew Bible again in Gen 46:34 and Exod 8:22. In both cases, the Hebrews use it in order to separate themselves from the Egyptians. ${ }^{54}$ These verses may therefore reflect the fact that integration in another culture has its limits. ${ }^{55}$

${ }^{49}$ T. RÖMER, “Goshen," EBR 10 (2015), cols 671-672.

${ }^{50}$ Goshen appears in the Joseph narrative (Gen 45:10; 46:28.34; 47:1.4.6.27; 50,8), in Exod 8:22; 9:26, and in Josh 10:41; 11,16. (Cf. also Jdt 1:9 (Gesem). The Egyptian terme gesem is attested in an inscription from the Ptolemaic period as a place in proximity to Avaris. LXX has Gesem Arabia(s) ou Herôou polis (=Pitom; Gn 46:28s.). In the Papyrus Revenue Laws (Ptolemy II, 283-246), the twentieth nome is called Arabia. Apparently the term designates a border territory between Egypt and the Levant.

${ }^{51}$ Translation: G. Rawlinson in http://classics.mit.edu/Herodotus/history.2.ii.html. Accessed 01/14/2021.

${ }^{52}$ Redford, A Study of the Biblical Story of Joseph (see n. 11), 235, evokes racial tensions in the Saite and Persian period. See also the discussion in T. Römer, "Deux repas 'en miroir' dans l'histoire de Joseph (Gn 37-50)," in Fête, repas, identité: Hommage à Alfred Marx à l'occasion de son 70e anniversaire (ed. C. Grappe; RHPhR 93; Strasbourg: Université de Strasbourg, 2013), 15-27, here 22-24.

${ }^{53}$ J. Yоуотте, "L'Egypte ancienne et les origines de l’antijudaïsme," RHR 163 (1963), 133-143.

54 J. Евасн, Genesis 37-50 (HTK.AT; Freiburg: Herder, 2007), 472-473. For a somewhat different interpretation see A. Pinker, 'Abomination to Egyptians' in Genesis 43:32, 46:34, and Exodus 8:22," OTE 22 (2009), 151-174.

${ }^{55}$ C. Levin, Der Jahwist (FRLANT 157; Göttingen: Vandenhoeck \& Ruprecht, 1993), 297. 
If the Joseph narrative is to be understood as a "Diaspora novella"56 then one must ask again why the hero "Joseph" is a character from the North. ${ }^{57}$ First of all, there are internal, "narratological" explanations. The author of the Joseph story knows the Jacob cycle, including the birth of Jacob's sons. According to this story, Joseph and Benjamin are the (only) sons of Rachel, Jacob's favorite wife. It is therefore quite logical for the author of the Joseph story to choose these two sons in order to construct his plot about the problem of preferred sons in a family. Second, the Northern character of Joseph could also be explained by the hypothesis that the Joseph story has a "Northern" origin. Genung argues that the Joseph story was composed in Samaria "nonetheless in communication with the Egyptian Diaspora community," ${ }^{38}$ written as an independent narrative after $\mathrm{P}$ and before the LXX. ${ }^{59}$

Nevertheless, it is still possible that the Joseph story originated in the Diaspora. One could, for instance, locate the author(s) of the story in Elephantine, ${ }^{60} \mathrm{a}$ colony, which may have had Northern origins. ${ }^{61}$ Although this Aramean speaking and writing community was mainly composed of soldiers, mercenaries, and peasants, there is evidence of literacy as shown by the important numbers of administrative and economic documents, in addition to the Aramaic version of the Ahiqar story discovered in Elephantine.

But it is also possible to locate the origin of the Joseph story in the Delta, which would also fit to the Northern character of Joseph.

According to Flavius Josephus there were also Samaritans living in Egypt during the Hellenistic time and perhaps even since the end of the Persian era (Ant. 11.321-322; 12.710). He also reports that under Ptolemy VI (180-145) there was a conflict between Jews and Samaritans living together in Alexandria over the question of whether the temple of Jerusalem or the sanctuary at Gerizim had been built according to the prescriptions the Torah (13.74-79). Andronicus, speaking for Jerusalem, "persuaded the king to decide that the temple in Jerusalem had been built in accordance with the laws of Moses" (13.79). If those tensions between Judeans and Samaritans arose only in the second century вСЕ, we might assume that there was a quite peaceful cohabitation of both groups in Egypt in late Persian and early Hellenistic times. If this were the case the Joseph story could have originated in a Samaritan Diaspora context.

\footnotetext{
${ }^{56}$ So also B. U. Schipper, "Joseph, Ahiqar, and Elephantine: The Joseph Story as a Diaspora Novella," Journal of Ancient Egyptian Interconnections 18 (2018), 71-84.

${ }^{57}$ Schмid, "Die Josephsgeschichte im Pentateuch", 110.

${ }^{58}$ Genung, The Composition of Genesis 37 (see n. 4), 210.

${ }^{59}$ Ibid., 212.

${ }^{60}$ M. Fieger and S. Hodel-Hoenes, Der Einzug in Ägypten: Ein Beitrag zur alttestamentlichen Josefsgeschichte (Bern: Peter Lang, 2007), 373-375.

${ }^{61}$ K. van DER Toorn, "Anat-Yahu, Some Other Deities, and the Jews of Elephantine," Numen 39 (1992), 80-101.
} 
The Northern Joseph who reconciles with his "southern" brothers, especially Judah, which is one of the major themes of the narrative, ${ }^{62}$ may reflect a cohabitation between Northern and Southern "Israelites," and also the collaboration between the authorities of Samaria and Jerusalem. The documentation from Elephantine shows that the Israelite-Judean Diaspora living there wrote simultaneously to the governors of Jerusalem and of Samaria concerning the question of the rebuilding of the Yahu-Temple. They received as an answer a common statement of Bagavahyah, governor of Judah, and of Delaiah, the son of the governor of Samaria, Sanballat. This suggests a friendly relationship between Samaria and Jerusalem at the end of the fifth century вСE, ${ }^{63}$ at a time where the sanctuary on Gerizim probably already existed. Apparently the Yahuworshippers in Elephantine thought that the leaders of Judah and Samaria both had influence over the rebuilding of the Yahu-Temple and other cultic concerns. These observations indicate a close collaboration between Jerusalem and Samaria, between the North and the South, that may be reflected in the Joseph narrative.

The theme of the Joseph story also fits a "pan-israelite" ideology corresponding to post-exilic prophetic texts, which announce a restoration of "Joseph" and "Judah" (Ezek 37:19; Zech 10:6).

\section{A Persian or Hellenistic Period Setting of the Joseph Story}

There are compelling arguments for understanding the Joseph story as a "late" text, perhaps even one of the latest writings of the Pentateuch. The question, which we will explore with some examples that follow, is whether the Joseph story reflects the context of the Persian or the Hellenistic period. The terminus ad quem for the dating the Joseph story, including later additions, is the translation of the Pentateuch into Greek, which is often situated in the first half of the third century $\mathrm{BCE},{ }^{64}$ but this date depends on the letter of Aristeas and may be

\footnotetext{
${ }^{62}$ See Fischer, "Versöhnung" (see n. 16) and also P. Weimar, "Josef - Eine Geschichte vom schwierigen Prozeß der Versöhnung (1995)," in Studien zur Josefsgeschichte (ed. P. Weimar; SBAB 44; Stuttgart: Katholisches Bibelwerk, 2008), 9-26.

${ }^{63}$ G. GranerøD, Dimensions of Yahwism in the Persian Period: Studies in the Religion and Society of the Judaean Community at Elephantine (BZAW 488; Berlin and New York: Walter de Gruyter, 2016), 41-44.

${ }^{64}$ A. vAN DER KooIJ "The Septuagint and Scribal Culture," in XIV Congress of the IOSCS Helsinki, 2010 (ed. M.K.H. Peters; SCS 59; Atlanta: SBL Press, 2013), 33-39; E. Tov, Textual Criticism of the Hebrew Bible (3rd ed.; Minneapolis, MN: Fortress Press, 2012), 131; M. Tilly, Einführung in die Septuaginta (Darmstadt: Wissenschaftliche Buchgesellschaft, 2005), 26-37. Cf. also T.H. Lim, The Formation of the Jewish Canon (The Anchor Yale Bible Reference Library; New Haven, CT: Yale University Press, 2013), 74-88.
} 
challenged, so that a later date, such as the end of the third or the beginning of the second century (fragments of Leviticus and Deuteronomy; Rahlfs nos. 801, 819 , and 957), ${ }^{65}$ is possible.

And indeed, there are some passages in the Joseph story that fit better in the Ptolemaic period than they do in the Persian period.

\subsection{Joseph's Second Dream}

37:9 He had another dream, and told it to his brothers, saying, "Look, I have had another dream: the sun, the moon, and eleven stars were bowing down to me." 10 But when he told it to his father and to his brothers, his father rebuked him, and said to him, "What kind of dream is this that you have had? Shall we indeed come, I and your mother and your brothers, and bow to the ground before you?"

Joseph's second dream is somewhat redundant in regard to the first one. The difference is that the first was only concerned with Joseph's brothers and provided an explanation for their jealousy. The second dream introduces the father and also the mother, who according to the narrative context of the story, does not exist anymore. Whereas the first dream has an agricultural setting, the second has a cosmological one.

There is no other example in the Hebrew Bible that sun, moon, and stars are under the control of a human being. Several biblical texts stress the fact that these celestial beings are under divine control and that they are part of Yhwh's celestial army.

In Ezra's prayer in Neh 9:6, we read:

"You are Yhwh, you alone; you have made heaven, the heaven of heavens, with all their host, ... To all of them you give life, and the host of heaven prostrates before you."

According to Joseph's second dream, sun, moon, and the stars prostrate before him as if he were God. The best parallel for this occurs in the Syriac version of the Ahiqar tradition (which was also known, in Aramaic at Elephantine) where Sennacherib is compared to "the god of heaven" who "commands thunder and lightning, the sun, the moon, and the stars."

The confusion between "God" and Joseph is a topic, that is taken up in other parts of the Joseph narrative. For instance, in Gen 40:8, after the two high-ranked prisoners have communicated their dreams to Joseph, he tells them: "Do not interpretations belong to God? Please tell them to me." And he then gives the interpretations that belong to God. Similarly, Joseph tells Pharaoh that not he, but 'elohim will explain his dreams, but he himself provided the interpretation (Gen 41:15-16 and 25). Finally, in Gen 50, when the brothers ask Joseph to forgive them, he answers: "am I in the place of 'elohîm?" (50:19). In a way the question remains open, and one may indeed read the narrative as a story about divine

${ }^{65}$ LXX fragments of Genesis are from the first century вСЕ. 
providence, or as the story of a powerful manipulation organized by Joseph in Egypt.

In the Ancient Near East and Egypt, the celestial bodies are associated or identified with deities. In Gen 37, sun and moon are apparently meant to represent Joseph's father and mother. Thus if one looks at the "gender" of these celestial bodies in Egypt and Mesopotamia, the sun (Ra/Shamash) and the moon (Thot/Sin) are male; at Ugarit, the sun (Shapshu) is female and the moon is male (Yarihu); in the Hebrew Bible, the sun (Shemesh) can be male or female, the moon (Yareah) is male. The only mythological context where the image of Joseph's second dream would fit is the Greek one: Helios (the sun, male) and Selena (the moon, female).

All this could thus suggest a Hellenistic setting for Joseph's second dreams. Although, Konrad Schmid has tried to show how this second dream makes perfect sense in the context of the Joseph narrative ${ }^{66}$ many scholars consider this passage as a later expansion of the original text. ${ }^{67}$ If this is the case, one could imagine a revision of the narrative in the Hellenistic period.

\subsection{Joseph's Departure from Hebron}

Gen 37:14 So, he said to him, "Go now, see if it is well with your brothers and with the flock; and bring word back to me." So, he sent him from the valley of Hebron. He came to Shechem.

According to Gen 37:14 Jacob is located in the vicinity of Hebron whereas in 33:1-20, after the reconciliation with his brother, he settles down in the vicinity of Shechem. The distance between Hebron and Shechem as the crow flies is about $75 \mathrm{~km}$, which does not seem to be a very logical distance for pasturing a flock. It is therefore plausible to consider the mention of Hebron as an addition, ${ }^{68}$ probably due to an effort of combining the Joseph narrative with the priestly document according to which Jacob moves to Mamre-Hebron (35:29) where he is buried (50:13).

The mention of the valley of Hebron is also intriguing since the Iron Age Hebron, which is to be identified with Tel Rumeida/Gebel er-Rumede, was located on a mountain. Apparently during the Persian period this site was unsettled

\footnotetext{
${ }^{66}$ K. Schmid, "Josephs zweiter Traum. Beobachtungen zu seiner literarischen Funktion und sachlichen Bedeutung in der Josephsgeschichte (Gen 37-50)," ZAW 128/3 (2016), 374-388.

${ }^{67}$ See for instance Genung, The Composition of Genesis 37 (see n. 4), 129-133; Ede, Josefsgeschichte (see n. 20), 48-49.

${ }^{68}$ H. Gunkel, Genesis (4th ed.; HKAT I/1; Göttingen: Vandenhoeck \& Ruprecht, 1917), 391; A. De Pury, Promesse divine et légende cultuelle dans le cycle de Jacob. Tome I et II (Etudes bibliques; Paris: J. Gabalda, 1975), 564-565; Seebass, Zeit (see n. 10), 77-78; B. J. SchwarTZ, "How the Compiler of the Pentateuch Worked: The Composition of Genesis 37", in The Book of Genesis. Composition, Reception, and Interpretation (ed. C.A. Evans et al.; VTSup 152; FIOTL 6; Leiden: Brill, 2012), 263-278, here 266-267, n. 10; Genung, The Composition of Genesis 37 (see n. 4), 194.
} 
and in the Hellenistic period Hebron resettled to a new location (Wadi el-Halil/ Nahal Hevron). ${ }^{69}$ Joseph's departure from Hebron may therefore best be understood against the backdrop of the Hellenistic period. ${ }^{70}$

\subsection{Pharaoh's Birthday}

Gen 40:20 On the third day, which was Pharaoh's birthday, he made a feast for all his servants, and lifted up the head of the chief cupbearer and the head of the chief baker among his servants. $21 \mathrm{He}$ restored the chief cupbearer to his cupbearing, and he placed the cup in Pharaoh's hand; 22 but the chief baker he hanged, just as Joseph had interpreted to them.

The conclusion of the narration about Joseph's interpretation of the dreams of the chief cupbearer and the chief baker finds its fulfillment at the occasion of the king's birthday (יום הלדת). As pointed out by Redford the celebration of Pharaoh's birthday is not attested before the Ptolemaic period. ${ }^{71}$ The Rosetta Stone (197 BCE) mentions the birthday of Ptolemy V, which is related to an amnesty: "whereas those who were in prison and those who were under accusation for a long time, he has freed of the charges against them", in addition to the killing of impious people. ${ }^{72}$

If one does not want to relate v. 20 to the Ptolemaic period one would need to view the "anniversary" as the anniversary of the king's ascent to the throne, but this theory is not very plausible because of the specific Hebrew term that is used. One could however imagine that the mention of the birthday is a later insertion in the original story.

It is also noteworthy that hanging is not used as a death penalty in Ancient Egypt: the current method of this rare practice was impalement. ${ }^{73}$ Does this mean that the author is not aware of Egyptian practices, or does he write in a time, where hanging has become more popular (see Esth 5:14, 6:4, 7,9-10, 8:7, 9:13-14, 9:25)?

\subsection{Pharaoh's Dreams and the Famine}

The so-called Famine Stele, discovered in 1889, on the Sehel Iland in the Nile near Aswan presents a close parallel to Pharaoh's dreams and their interpretation by Joseph. The text presents itself has having been written in the eighteenth year of

\footnotetext{
${ }^{69}$ D. JeRICKe, Die Ortsangaben im Buch Genesis: ein historisch-topographischer und literarisch-topographischer Kommentar (FRLANT 248; Göttingen: Vandenhoeck \& Ruprecht, 2013), 16-35.

${ }^{70}$ See also Genung, The Composition of Genesis 37 (see n. 4), 215-216.

${ }^{71}$ Redford, A Study of the Biblical Story of Joseph (see n. 11), 205-206.

${ }^{72}$ English translation of the Greek section: http://www.reshafim.org.il/ad/egypt/texts/ro settastone.htm; see also http://rosettastone.hieroglyphic-texts.net/whole_text_with_ids/. Accessed 01/25/21.

${ }^{73}$ Oral communication by Youri Volokhine, Geneva.
} 
king Djoser, who is presented at the top of the stele with three Egyptian deities, but the text was actually written during the reign of Ptolemy V (around 187) as a legitimation of the priesthood of Khnum over Egypt. ${ }^{74}$ Like the Joseph story, the famine stele mentions seven years of hunger, which is the situation of the land when the dream revelation occurs, in which the deity promises Pharaoh to bring the famine to an end. As a sign of gratitude, the king makes a grant to the temple of Khnum in Elephantine. The parallels between both texts are numerous:

\begin{tabular}{lll} 
& Joseph & Famine stela \\
\hline Threat of famine & 7 years to come & $\begin{array}{l}7 \text { years of famine have exhausted the land: } \\
\text { "Hapy had failed to come in time, in a } \\
\text { period of seven years." }\end{array}$
\end{tabular}

Mention of grains 7 good years, 7 thin years "Grain was scant, kernels were dried up."

Revelation Dream Dream

"I shall make Hapy gush for you, no year of lack and want anywhere ... Gone will be the hunger years, ended the dearth in their bins."

$\begin{array}{lll}\text { Deity } & \text { (Ha-)Elohim } & \text { Khnum } \\ \text { Mediator } & \text { Joseph } & \text { Imhotep } \\ & \begin{array}{l}\text { Ha-elohim has decided } \\ \text { everything }\end{array} & \begin{array}{l}\text { Reconstruction and cult of Khnum } \\ \text { in Elephantine }\end{array}\end{array}$

Recently Bernd Schipper has drawn attention to papyrus BM 10565 from the Roman period which mentions the failed flooding of the Nile and seven years of the Nile's abundance of water, as well as the papyrus Berlin 23071 which, although dating to the first or second century, may contain an older text from the Persian or Ptolemaic period. ${ }^{75}$ The Berlin papyrus also mentions a famine of seven years, a dream of the pharaoh, and an overseer appointed by the king to resolve the problem. The Berlin papyrus mentions the temple of Heliopolis, and in the Joseph story (Gen 41:45), Joseph marries the daughter of a priest of On (Heliopolis). These texts belong to the "Book of the Temple" tradition that was widely distributed in Ptolemaic and Roman Egypt, and may have influenced the famine stele. According to Schipper the tradition of seven years of famine could be dated to the late Persian period, so that the story of Pharaoh's dream may have been composed during that time.

\footnotetext{
${ }^{74}$ B. U. SCHipper, "Joseph, Ahiqar, and Elephantine" (see n. 56).

${ }^{75}$ Ibid., 77.
} 


\subsection{Joseph's Invention of Capitalism ${ }^{76}$}

${ }^{13}$ Now there was no food in all the land, for the famine was very severe. The land of Egypt and the land of Canaan languished because of the famine. ${ }^{14}$ Joseph collected all the money to be found in the land of Egypt and in the land of Canaan, in exchange for the grain that they bought; and Joseph brought the money into Pharaoh's house. ${ }^{15}$ When the money from the land of Egypt and from the land of Canaan was spent, all the Egyptians came to Joseph, and said, "Give us food! Why should we die before your eyes? For our money is gone." ${ }^{16}$ And Joseph answered, "Give me your livestock, and I will give you food in exchange for your livestock, if your money is gone." ${ }^{17}$ So they brought their livestock to Joseph; and Joseph gave them food in exchange for the horses, the flocks, the herds, and the donkeys. That year he supplied them with food in exchange for all their livestock. ${ }^{18}$ When that year was ended, they came to him the following year, and said to him, "We cannot hide from my lord that our money is all spent; and the herds of cattle are my lord's. There is nothing left in the sight of my lord but our bodies and our lands. ${ }^{19}$ Shall we die before your eyes, both we and our land? Buy us and our land in exchange for food. We with our land will become slaves to Pharaoh; just give us seed, so that we may live and not die, and that the land may not become desolate." ${ }^{20}$ So Joseph bought all the land of Egypt for Pharaoh. All the Egyptians sold their fields, because the famine was severe upon them; and the land became Pharaoh's. ${ }^{21}$ As for the people, he removed them to the cities from one end of Egypt's border to the other. ${ }^{22}$ Only the land of the priests he did not buy; for the priests had a fixed allowance from Pharaoh, and lived on the allowance that Pharaoh gave them; therefore, they did not sell their land. ${ }^{23}$ Then Joseph said to the people, "Now that I have this day bought you and your land for Pharaoh, here is seed for you; sow the land. ${ }^{24}$ And at the harvests you shall give one-fifth to Pharaoh, and four-fifths shall be your own, as seed for the field and as food for yourselves and your households, and as food for your little ones." ${ }^{25}$ They said, "You have saved our lives; may it please my lord, we will be slaves to Pharaoh." ${ }^{26}$ So Joseph made it a statute concerning the land of Egypt, and it stands to this day, that Pharaoh should have the fifth. The land of the priests alone did not become Pharaoh's.

Many scholars would agree that Gen 47:13-26 does not belong to the original Joseph story. Joseph's brothers and father are not mentioned, and the whole story is concerned with showing how Joseph brings all economic power into the hands of Pharaoh: money, livestock, the lands of the Egyptians, and the Egyptians themselves, who become slaves of the king. ${ }^{77}$

${ }^{76}$ For the following passage see my detailled treatment in T. Römer, "Joseph, inventeur du capitalisme (Gn 47,13-26): enjeux économiques et politiques dans un ajout à l'histoire de Joseph," in Bible et Politique: Hommage au Professeur Olivier Artus pour son 65ème anniversaire (ed. S. Ramond and P.J. Titus; Bangalore: ATC Publishers, 2019), 17-34.

${ }^{77}$ See among others, H.-C. Schmitt, Die nichtpriesterliche Josephsgeschichte: Ein Beitrag zur neuesten Pentateuchkritik (BZAW 154; Berlin: Walter de Gruyter, 1980), 64-65; WestermanN, Genesis 37-50 (see n. 33), 186; H. Seebass, Genesis III: Josephgeschichte (37,1-50,26) (Neukirchen-Vluyn: Neukirchner Verlag, 2000), 142-143; Levin, Jahwist (see n. 53), 306; According to WeIMAR, "Gen 47,13-26" (see n. 10), here 137 this passage belongs to one of the latest texts in the Pentateuch. See similarly EdE, Josefsgeschichte (see n. 20), 393. For the discussion whether the passage was written by one redactor, or whether one should distinguish two or more hands see the discussion in RÖMER, "Capitalisme" (see n. 76). 
It is possible that this passage reflects economic changes at the beginning of the Ptolemaic period. First of all, it is interesting that v. 13-15 mention the land of Egypt and the land of Canaan (Joseph also collects money in Canaan!). This may reflect the incorporation of the Levant into the Ptolemaic kingdom under Ptolemy Soter I (around 320-315). According to the MT of v. $21^{78}$ Joseph transfers the people to cities, which may reflect urbanization under the Ptolemaic rulers. According to Flavius Josephus (Ant 12:7), Ptolemy, having laid siege to Jerusalem in 312, deported an important number of the habitants to Alexandria. This was part of the process of urbanization in Egypt, which affected also Memphis and Canopus. ${ }^{79}$

Finally, one may compare the acting of Joseph in this passage to the strategies of Cleomenes of Naucratis as an administrator and builder of Alexandria. When there was a scarcity of grain in Alexander's empire, which was less severe in Egypt than in the neighboring countries, he first forbade its export from Egypt. Later he allowed export but placed heavy taxes on it. ${ }^{80}$

In a way, Joseph acts in Gen 47:13-26 as a dioecete, which after the Ptolemaic king was the most important person. This passage was probably also written when the Joseph story was already conceived as an introduction to the Exodus story, ${ }^{81}$ because it contains ironic allusions to the latter. It shows that before the Hebrews became slaves of the Pharaoh, a Hebrew (Joseph) made all the Egyptians slaves of their king.

\section{Conclusion}

The Joseph narrative, now integrated into Gen 37-50, was originally an independent narrative. It was inserted at the end of Genesis after the integration of the P-texts, ${ }^{82}$ by redactors who wanted to construct a Hexa- or a Pentateuch and give some space also to a voice of the Diaspora.

The Joseph narrative can be characterized as a "Diaspora novella." Its ideology reflects the situation of the Diaspora as known from the Elephantine texts (double

\footnotetext{
${ }^{78}$ LXX and Sam: "as for the people, he made slaves of them from one end of Egypt to the other." This is a correction of the somewhat complicated Hebrew text.

${ }^{79}$ For the process of urbanization under the Lagides see A. Aymard and J. Auboyer, L'Orient et la Grèce antique (Histoire générale des civilisations; Paris: Presses universitaires de France, 1963), 452; A. Bowman, "Ptolemaic and Roma Egypt: Population and Settlement," in Urbanization and Population (ed. A. Bowman and A. Wilson; Oxford and New York: Oxford University Press, 2011), 317-358, here 326-327.

${ }^{80}$ G. Le Rider, "Cléomène de Naucratis," BCH 121 (1997), 71-93, here 74.

${ }^{81}$ EDE, Josefsgeschichte (see n. 20), 393.

82 Theoretically the Joseph narrative could have been written down earlier than the composition of $\mathrm{P}$, and $\mathrm{P}$ would have ignored it. But if $\mathrm{P}$ is to date at the beginning of the Persian period, then it seems more logical that the Joseph narrative is younger than $\mathrm{P}$.
} 
names, intermarriages, etc.). Its author perhaps originated from the North and wanted to show the importance of the Diaspora for "all Israel."

The date of the original narrative can be the late Persian period, and while there are several passages that fit better into a Greek, Ptolemaic context, most of these passages belong to later revisions. 



\title{
Stripping off the Robe
}

\author{
New Light on "Joseph the Hebrew" and the bet-yosef
}

\section{Lauren Monroe}

In the family saga that occupies the end of the book of Genesis, the name Joseph is tied to one of the two youngest sons of Jacob by his favored wife, Rachel. This Joseph is incorporated into a twelve-tribe vision of Jacob as Israel in which Joseph is but one element. But as a single member of a larger collective, Joseph stands out as distinct among his brothers, first, for the sheer space allotted to him in the book of Genesis - far more than any other of Jacob's progeny. In addition, he is the only son whose bones travel with the Israelites in their departure from Egypt to Canaan. ${ }^{1}$ He appears to be the youngest son of Jacob in Gen 37, but in other contexts is the eldest of Rachel's two boys. ${ }^{2}$ Within the twelve-tribe territorial vision of Israel that is set forth in the book of Joshua and that dominates biblical tradition, Joseph is equated with Ephraim and Manasseh, ${ }^{3}$ two sons borne to him by his Egyptian wife Asenath, ${ }^{4}$ and blessed by a dying Jacob, as if they were his own sons. ${ }^{5}$ The incorporation of Ephraim and Manasseh into the family of Jacob, puts Joseph in an awkward position vis-à-vis the twelvetribe system to which he ostensibly belongs. He stands at a distance, replaced in effect by his sons, so not quite a tribe like his brothers, while at the same time he is positioned so as to receive a double inheritance, in the central highlands of Canaan no less; that is, in the very heartland of Israel.

${ }^{1}$ The transport of Joseph's bones is mentioned three times in the Hexateuch, in Gen 50:2426; Ex 13:19; and Josh 24:32. As discussed at greater length below, this may be an instance of over-communication, intended to strengthen ties between Joseph and Canaan.

${ }^{2}$ E. g., Gen 35:24; 42:33-36; 43:29.

${ }^{3}$ See especially Josh 16:4.

${ }^{4}$ Gen 41:51-52.

${ }^{5}$ Gen 48 . 
Biblical scholars have long noted the unique literary artistry the Joseph story manifests, ${ }^{6}$ its Egyptianizing elements, ${ }^{7}$ and its possible role as a bridge between the Canaan-based patriarchal narratives of Genesis and the Egypt-based Exodus story. ${ }^{8}$ In addition, traditional source critical approaches identify the Joseph story as a locus classicus for J-E source divisions. ${ }^{9}$ Yet, despite this attention and the unusually large space the Joseph story occupies in the book of Genesis, remarkably little is understood of Joseph's significance for the ancient Israelites. To whom was his story important? How and why did this narrative come to occupy such a prominent place in the Pentateuch?

${ }^{6}$ E.g., R. Alter, The Art of Biblical Narrative (London and Sydney: G. Allen and Unwin, 1981), 159-177; R. PIRson, The Lord of the Dreams: A Semantic and Literary Analysis of Genesis 37-50 (JSOTSup 355; London: Sheffield Academic Press, 2003); B. U. Schipper, "Joseph, Ahiqar, and Elephantine: The Joseph Story as Diaspora Novella," Journal of Ancient Egyptian Interconnections 18 (2018), 71-84; M. STERNBERG, The Poetics of Biblical Narrative: Ideological Literature and the Drama of Reading (Bloomington, IN: Indiana University Press, 1987); A. WÉNIN, "Le temps dans l'histoire de Joseph (Gn 37-50): Repères temporels pour une analyse narrative," Bib. 83/1 (2002), 28-53.

${ }^{7}$ E.g., M. Fieger and S. Hodel-Hoenes, Der Einzug in Ägypten: ein Beitrag zur alttestamentlichen Josefsgeschichte (Bern: Peter Lang, 2007); E.W. Hengstenberg, Die Bücher Mose's und Ägypten nebst einer Beilage: Manetho und die Hyksos (Berlin: Oemigke Verlag, 1841); K.A. KITChen, The Third Intermediate Period in Egypt, 1100-650 B.C (2nd ed. with suppl., new preface; Warminster: Aris \& Phillips, 1996); D. B. Redford, A Study of the Biblical Story of Joseph (Genesis 37-50) (VTSup 20; Leiden: Brill, 1970); T. Römer, "The Role of Egypt in the Formation of the Hebrew Bible," Journal of Ancient Egyptian Interconnections 18 (2018), 63-70; B. U. SCHIPper, "Gen 41:42 and the Egyptian Background to the Investiture of Joseph," RB 118/3 (2011), 331-38; IDEM, "Joseph, Ahiqar and Elephantine" (see n. 1), 71-84; H. Seebass, "Joseph, sein Vater Israel und das pharaonische Ägypten," in Nachdenken über Israel, Bibel und Theologie: Festschrift für Klaus-Dietrich Schunck zu seinem 65. Geburtstag (ed. H. M. Neimann et al.; BEATAJ 13; Frankfurt a. M.: Peter Lang, 1994), 11-25; J. Vergote, Joseph en Égypte: Genèse Chap. 37-50, à la lumière des études égyptologiques récentes (OBL 3; Leuven: Peeters, 1959).

${ }^{8}$ First proposed by M. Nотн, Überlieferungsgeschichtliche Studien (Halle: M. Niemeyer, 1943), 226-227. More recent treatments of this issue include, D. M. CARR, "Genesis in Relation to the Moses Story. Diachronic and Synchronic Perspectives," in Studies in the Book of Genesis: Literature, Redaction and History (ed. A. Wénin; Leuven: Peeters, 2001), 273-296; R. G. Kratz, The Composition of the Narrative Books of the Old Testament (London: T \& T Clark, 2005), 274-283; K. SснміD, "Die Josephsgeschichte im Pentateuch," in Abschied vom Jahwisten: Die Komposition des Hexateuch in der jüngsten Diskussion (ed. J.C. Gertz et al.; BZAW 315; Berlin: Walter de Gruyter, 2002), 83-118; IDEM, "The So-Called Yahwist and the Literary Gap between Genesis and Exodus," in A Farewell to the Yahwist?: The Composition of the Pentateuch in Recent European Interpretation (ed. T. B. Dozeman and K. Schmid; Atlanta, GA: Society of Biblical Literature, 2006), 29-50; K. SCHmid, Genesis and the Moses Story: Israel's Dual Origins in the Hebrew Bible (Siphrut: Literature and Theology of the Hebrew Scriptures 3; Winona Lake, IN: Eisenbrauns, 2010).

${ }^{9}$ See most recently, J.S. BAden, The Composition of the Pentateuch: Renewing the Documentary Hypothesis (ABRL; New Haven, CT: Yale University Press, 2012), 34-44; and IDEM, "The Continuity of the Non-Priestly Narrative from Genesis to Exodus", Bib. 93/2 (2012), 161186. See also, in the same volume, the response to Baden by K. Schmid, "Genesis and Exodus as Two Formerly Independent Traditions of Origins for Ancient Israel," Bib. 93/2 (2012), 187-208. 
One trend is to treat the story as a so-called "Diaspora novella," "conceived in order to reflect the possibilities of life outside the land," in Thomas Römer's words. ${ }^{10}$ Several contributors to this volume understand this as the best explanation for such features as: the story's interest in local details relating to its Egyptian setting; Joseph's death in Egypt and the general lack of interest in escape that provides the foundation for the exodus traditions; the absence of the theme of kingship; and the fact that biblical references to the Joseph story are scarce outside the Hexateuch. An interest in Joseph is well-documented for the exilic and post-exilic periods, primarily through long-noted echoes of Joseph in the books of Esther and Daniel, but also through parallels wrought between the figures Joseph and Jeremiah. ${ }^{11}$ In addition, there is evidence of late Priestly and/or post-Priestly additions within the Joseph story itself, with debate over their intent and extent. Much later, the Hellenistic tale of Joseph and Asenath reflects an enduring interest in the figure of Joseph as a model of life in the Jewish diaspora.

Indeed, there is no other individual within the so-called historical books of the Bible as amenable to diaspora interests. One possible explanation for this is to understand the Joseph story as having been conceived within a diaspora setting. Römer, arguing for the Joseph story as a post-Priestly addition to the end of Genesis, has attempted to reconstruct what a story of Jacob and his sons might have looked like without Joseph; ${ }^{12}$ but to my mind, this is precisely where the idea of the Joseph story as a Persian period diaspora composition falls short. Israel Finkelstein and Thomas Römer, among others, have argued convincingly that the story of Jacob and his sons originated in a northern context, and was first written down no later than the eighth century, as an expression of northern monarchic political ambitions. ${ }^{13}$ The names of Jacob's sons would have been in-

${ }^{10}$ T. RöMer, “The Joseph Story in the Book of Genesis: Pre-P or Post-P?," in The PostPriestly Pentateuch. New Perspectives on Its Redactional Development and Theological Profiles (ed. F. Giuntoli and K. Schmid; FAT 101; Tübingen: Mohr Siebeck, 2015), 185-202, here 192. See also, Schipper, "Joseph, Ahiqar, and Elephantine" (see n. 1), 71-84; Schmid, "Die Josephsgeschichte im Pentateuch" (see n. 8), 111. For a thorough treatment of the history and foundations of this understanding of the Joseph story, especially in a German setting, see E. BLUM and K. WeINGART, "The Joseph Story: Diaspora Novella or North-Israelite Narrative?, ZAW 129/4 (2017), 501-521.

${ }^{11}$ This is the subject of recent research in progress by Andrew Teeter.

${ }^{12}$ Römer, "Joseph Story in Genesis" (see n. 10), 200-201.

${ }^{13}$ I. Finkelstein and T. Römer, "Comments on the Historical Background of the Jacob Narrative in Genesis," ZAW 126/3 (2014), 317-338. See also, E. BLum, "The Jacob Tradition," in The Book of Genesis: Composition, Reception, and Interpretation (ed. C.A. Evans et al.; Leiden: Brill, 2012), 181-211; D. M. CARR, Reading the Fractures of Genesis: Historical and Literary Approaches (Louisville, KY: Westminster John Knox Press, 1996), 256-268. It is worth noting Carr's observation that Joseph is the only son mentioned by name in the episode of reconciliation between Jacob and Esau in Gen 33:2, 7. A. DE PURY, "Situer le cycle de Jacob: Quelques réflexions, vingt-cinq ans plus tard," in Studies in the Book of Genesis (see n. 8), 213241; J.L. SKa, Introduction to Reading the Pentateuch (Winona Lake, IN: Eisenbrauns, 2006), 
tegral to this narrative, as they provide full geographic coverage for an Israel that stretched north of Jezreel Valley and east of the Jordan River, a point to which I shall return. In the biblical story of Jacob and his sons, Joseph is the primary focus and fulcrum around which the narrative unfolds. This is as true for the extended story that begins in Gen 37 as it is for the birth story itself, in Gen 30, which, as Daniel Fleming has demonstrated, culminates, and reaches its climax in the birth of Joseph by Jacob's favored, and previously barren wife, Rachel. Fleming associates this interest with an original birth story that pre-dates, and was expanded to accommodate a northern monarchic vision of Jacob as Israel. ${ }^{14}$ The likely eighth-century terminus ad quem for the composition for the story of Jacob and his sons, and the importance of Joseph within that story, casts doubt on the idea of the Joseph story as an independent diaspora novella.

Franziska Ede, who also regards the story as a diaspora text, has argued for a Fortschreibungsmethode of composition that originated primarily with core material in Gen 39-41, together with parts of the introduction in Gen 37, and grew outward in stages from there. ${ }^{15}$ I will argue here, with Ede, that Gen 39-41, which feature Joseph, a Hebrew alone in Egypt, with no brothers and no explicit connection to Canaan, preserve some of the oldest material in the Joseph story. ${ }^{16}$ I diverge from Ede in my reconstruction of the literary historical relationship between this core material and the introduction to the canonical Joseph story in Gen 37, which I understand to belong to a later, Jacob-oriented, expansion. Furthermore, I argue for a much earlier social and temporal horizon for what I will refer to here as the "Joseph the Hebrew" narrative contained in 39-41, suggesting that it predates and gave shape to the northern monarchic story of Jacob and his sons, preserved in Gen 37-50. At the same time, late additions to and retouching of the Joseph story is evident, and argues in favor of Reinhard Kratz' assessment that, "Both the national history and diaspora situation play a role."17 The figure of Joseph was repeatedly re-presented, re-incorporated and re-configured, becoming "more and more a paradigm of the kingdom and people of Israel." ${ }^{8}$

140. K. WeINGART, Stämmevolk - Staatsvolk - Gottesvolk?: Studien zur Verwendung des IsraelNamens im Alten Testament (Tübingen: Mohr Siebeck, 2014), 258-261.

${ }^{14}$ D. Fleming, "Joseph and His Allies in Genesis 29-30," in McCarter Festschrift, forthcoming (ed. C. Rollston et. al.). Drawing on work of D. NAsH, "'Your Brothers, the Children of Israel': Ancient Near Eastern Political Discourse and the Process of Biblical Composition," Cornell University Ph.D. dissertation, 2015, Fleming argues that the notion of Joseph as connected to tribal "brothers," indicates political distance and alliance between separate groups, not segments within a single people.

${ }^{15}$ F. EDE, Die Josefsgeschichte: Literarkritische und redaktionsgeschichtliche Untersuchungen zur Entstehung von Gen 37-50 (BZAW 485; Berlin: Walter de Gruyter, 2016).

${ }^{16}$ Late additions to this material are also evident, as I discuss in greater detail below.

${ }^{17}$ KrATZ, The Composition of the Narrative Books of the Old Testament (see n. 8), 278.

${ }^{18}$ Ibid., 278. 


\section{1. "Israel" and the bet-yosef}

The name Israel appears, famously, for the first time in the Egyptian Merenptah stele in the late thirteenth century and then not again until the ninth century Tel Dan and Mesha Inscriptions, as well as in the Assyrian annals of Shalmaneser III. The intervening three hundred years history, in which Israel went from a small feature in the Levantine landscape to a full-fledged monarchy, is poorly understood, and obscured, rather than illuminated by the broad strokes of the biblical narrative. In a pair of forthcoming articles, Fleming and I attempt to fill out some of this picture by tracing a transition the Bible preserves from what we refer to as little Israel, situated primarily in the central highlands of Canaan, in the territory associated in Joshua with the tribes of Ephraim, Manasseh and Benjamin, to a Greater Israel that stretched north of the Jezreel Valley and east of the Jordan River. ${ }^{19}$ We argue that Greater Israel does not come into view in texts or archaeology until the Omrides of the ninth century.

The present work is an outgrowth of this collaboration and reflects work in progress on a book entitled, Joseph the Hebrew and the Genesis of Ancient Israel. To my knowledge, this will be the first study to treat the Joseph story systematically together with references to Joseph outside of the Hexateuch. In particular, I am interested in the relationship between the Joseph story and the bet-yosef, or House of Joseph, an entity that appears eight times outside of Genesis, and only in Nevi'im. ${ }^{20}$ In most of these instances, the term signifies the northern kingdom as a territorial counterpart to Judah. For example, in Zech 10:6 the prophet assures, "I will give victory to the House of Judah (בית יהודה) and triumph to the House of Joseph (בית יוסף)." Similarly, Josh 18:5 presents a bi-partite division in which "Judah shall remain by its territory in the south, and the house of Joseph shall remain by its territory in the north." Obadiah pairs the House of Jacob, here a designation for Judah, and the House of Joseph as counterparts that together will defeat the House of Edom. In a prophecy against the House of Israel (בית ישראל (ישר), Amos 5 inveighs, "seek Yahweh and you will live, else he will rush like fire upon the House of Joseph and consume Bethel with none to quench it." Judg 1 likewise associates the House of Joseph with Bethel, and the received text clearly intends it as counterpart to Judah, though here the text may preserve a set of older associations, as I suggest below.

Scholars do not tend to read the Joseph story in light of the bet-yosef texts; yet they often take for granted that references to the bet-yosef have the Genesis story in mind. ${ }^{21}$ They either explicitly or implicitly understand the "House of Joseph"

\footnotetext{
${ }^{19}$ D. Fleming, “The Bible's Little Israel: Textual Inclusions in a Later Matrix," HBAI, forthcoming; L. Monroe, "On the Origins and Development of Greater Israel", HBAI, forthcoming.

${ }^{20}$ Josh 17:17; 18:5; Judg 1:22-23, 35; 2 Sam 19:21; 1 Kgs 11:28; Amos 5:6; Zech 10:6.

${ }^{21}$ E.g., E. BLum, Die Komposition der Vätergeschichte (WMANT 57; Neukirchen-Vluyn: Neukirchener Verlag, 1984), 183; CARR, Reading the Fractures (see n. 13), 265; C. L. Meyers and
} 
to refer to Joseph's sons Ephraim and Manesseh, whom they take to represent the core of the northern kingdom. However, with one exception, which I shall turn to shortly, in contrast to the b'nai yosef, or "sons of Joseph" the bet-yosef is never identified with Ephraim and Manasseh, nor is there any evidence that it is tied to the tradition of Jacob and his sons that provides a genealogical basis for the territorial schema set forth in Joshua. In fact, the very name "House of Joseph" implies a lineage for Joseph that is distinct from the "House of Jacob." 22 This raises the critical, and to my knowledge untreated, question of how the name betyosef (and not b'nai yosef) came to be associated with the northern kingdom. It is my contention that the name bet-yosef has deep ties to the political history of the kingdom of Israel, and that the story of "Joseph the Hebrew," preserved in Gen 39-41, may have originated as an ancestor tradition of the bet-yosef. This story and the contours of the bet-yosef itself, were reworked in an Israelite monarchic setting to accommodate a more expansive territorial vision of Greater Israel in which Jacob was pater familias.

Römer has divided references to Joseph outside the Hexateuch into three categories: neutral references to the bet-yosef in Judg 1, 2 Sam 19 and 1 Kgs 11; prophetic oracles of destruction and rejection in Amos 5, Obad 18 and Ps 78; and post-exilic announcements of restoration in Ezek 37, 47 and 48, and Ps $77 .{ }^{23}$ It is worth noting that in Römer's scheme the so-called "neutral references" all occur in texts set in the period before the establishment of the northern kingdom. In the discussion that follows, I focus first on these three texts, suggesting that when each is read on its own terms, without influence from formulations and systems presented elsewhere in the biblical corpus, the name bet-yosef cannot possibly refer to the northern kingdom we come to know by the ninth century. These texts, I will argue, offer important perspective on the identity of the bet-yosef as a feature of both biblical literature and of early Israel's socio-political landscape, as it is recalled in biblical texts. From here, I will move on to a literary historical analysis of the Joseph story itself, suggesting that embedded in this iconic narrative is an older, self-contained story of "Joseph the Hebrew," who rises to the rank of second in command over all of Egypt. This Joseph has no connection to Jacob or brothers in Canaan; it is a Joseph unadorned by the cloak of his father's favor and unburdened by his brothers' jealousy. When this core material is considered in light of the bet-yosef traditions, a portrait of the Israelite ancestor emerges that is deeply rooted in the socio-political landscape of Israel before the Omrides, an elusive phase in Israel's past, from the standpoint of both texts and archeology.

E. M. Meyers, Zechariah 9-14: A New Translation with Introduction and Commentary (AB 25C; New York: Doubleday, 1993), 207.

${ }^{22}$ The designation בית יעקוב occurs once in the Pentateuch, in Ex 19:3 and is well-attested in prophetic literature, with the most frequent use in the book of Isaiah, where it occurs nine times.

${ }^{23}$ RÖMER, "Joseph Story in Genesis" (see n. 10), 190 n. 25. 
To further anticipate my conclusions, I will suggest that certain features of the bet-yosef as they are preserved in the Bible, map well onto the geo-political landscape of the Late Bronze Age Levant as revealed especially in the fourteenth century Egyptian Amarna archive. When the relevant biblical texts are considered in light of the Amarna evidence, the bet-yosef comes into focus as an Iron Age vestige of the Late Bronze Age system of Egyptian administrative control in the region. I do not mean to suggest that the texts that preserve these bet-yosef traditions originate in this early period, or even that the authors necessarily understood the term's early significance. Rather by incorporating and reorienting older traditions, the received biblical narratives inadvertently provide access to a set of associations for the name bet-yosef that are different from its use to connote "Israel" or the northern kingdom in later periods. The idea that the bet-yosef was tied to Egyptian administration in Canaan is consistent with what I will posit is its legitimating tale of "Joseph the Hebrew," the Yahweh-worshiping eponymous ancestor who rises to a position of great power in the Egyptian court. Like the bet-yosef traditions, this story too was reoriented in the service of a later narrative that incorporated Joseph into the family of Jacob/Israel. I will suggest that the association of the figure of Joseph with the bet-yosef, and the importance of the bet-yosef in pre- and early monarchic Israel helps to explain the incorporation of Joseph into the family of Jacob as part of the process of constructing tribal Israel. It also helps to explain the prominent position Joseph occupies within that foundational biblical narrative. The name "Joseph" is thus intimately tied to the formation of ancient Israel, in both literary and political terms.

\section{The bet-yosef in Pre- and Early Monarchic Contexts}

\subsection{Samuel 19:20-21}

2 Sam 16 recounts the story of a certain Benjaminite Saul-loyalist, by the name of Shimei ben Gera, who appears before David, cursing him for having seized the throne of Saul. In 2Sam 19 after the death of Absalom, as preparations are being made to escort David back across the Jordan, Shimei hurries to meet the king, flings himself before him and begs his forgiveness. In v. 20 and 21 he pleads,

Do not think of me, my lord, as guilty and do not remember the wrong your servant committed on the day my lord the king set forth from Jerusalem that the king should take it to heart. For your servant knows that I have sinned. See? I have come today, the first of the entire house of Joseph (ראשון לכל-בית יוסף) to come down to meet my lord the King.

Given the setting of this narrative in the early days of the monarchy, it is impossible to understand this reference to the bet-yosef in terms of a northern kingdom as such, even as a concept imposed anachronistically. 
One might take bet-yosef as a reference to Ephraim and Manasseh, that is, the Joseph tribes as these are defined in Joshua's tribal-territorial lists. However, Shimei’s identification as בן הימיני אשר מבחורים, literally "of the Yemini who are from Bahurim" suggests that Shimei's tribal identity is defined in the text neither in terms of Ephraim and Manasseh nor for that matter by way of Joseph. His identification with the bet-yosef is a secondary affiliation separate from his tribal identity. Furthermore, as noted, with one exception, unlike the b'nai-yosef, the bet-yosef is never associated with Ephraim and Manasseh. The exception appears in Josh 17:17.

${ }^{14}$ The b'nai yosef said to Joshua, 'Why have you given me only one allotment and one portion for an inheritance? I am a numerous people (ואני עם רב) and Yahweh has blessed me abundantly.' ${ }^{15}$ Joshua said to them, 'You are a numerous people (עם רב רב אתה) Go up to the forest and clear land for yourselves there in the land of the Perizzites and Repha'im, for the hill country of Ephraim is too tight for you.'16 The b'nai yosef replied, 'The hill country is not enough for us, and all the Canaanites who live in the plain have iron chariots, both those in Beth Shan and its settlements and those in the Valley of Jezreel. ${ }^{17}$ Joshua said to the bet yosef - to Ephraim and Manasseh - 'You are a numerous people of great strength (עם רב אתה וכח גדול לך) You will not have only one allotment.'

Reference to Ephraim and Manasseh in verse 17 is likely to be a gloss in the Masoretic Text, intended to mitigate the unusual and repeated identification of the bet-yosef as an עם רב, a "great" or "mighty" people, a designation that is unexpected in reference to a single named group in Joshua's schematic allotment of tribal territories. ${ }^{24}$ By explaining that by bet-yosef the authors really mean Ephraim and Manasseh, the glossator in effect harmonizes the bet-yosef to the b'nai-yosef mentioned earlier in the passage, resolving an inconsistency in the text and forging an equivalency that is not in fact supported by the distribution of references to bet-yosef elsewhere in the biblical corpus.

Returning to 2 Sam 19, P. Kyle McCarter suggests that we are to think of Shimei's reference to the bet-yosef as signifying all of the northern tribes, in contrast to the "House of Judah." This would be close to the use of bet-yosef terminology elsewhere in the Bible, where it refers to the northern kingdom as a counterpart to Judah; however, 2 Sam 19 would be the only instance of that usage in a setting that pre-dates the establishment of the northern kingdom, and the absence of any interest in Judah casts doubt on this identification. Taking the text at face value, the name bet-yosef here seems to connote a substantial, recognized collective (we might even say an עם רב to use the language of Josh 17) to which Shimei of the Yemini belongs. The bet-yosef is at once distinct from and essential to the establishment of the "Israel" that David comes to rule.

\footnotetext{
${ }^{24} \mathrm{On}$ "Ephraim and Manasseh" as a gloss in this passage, see for example, R. G. Boling and G. E. Wright, Joshua (Garden City, NY: Doubleday, 1982), 418.
} 
The importance of the bet-yosef in ratifying Israel's kingship may be intimated in David's rhetorical exclamation in 19:23, "Should a man within Israel die this day (היום יומת איש בישראל)? For do I not know that this day I am King over Israel (על ישראל כי היום אני מלשלד)." The repetitive structure of this verse, including its triple emphasis on היום מל "this day," suggests a change of status for both David and Shimei. Through Shimei's public acceptance of David, not only does David become מלך על ישראל (king over Israel) but Shimei becomes איש בישראל (a man in Israel); that is, Shimei's identification as a part of Israel is directly tied to his acceptance of David's rule. This may be significant for trying to understand the relationship between Israel and the bet-yosef; however, these two entities were connected, it is Israel that is ruled.

\subsection{Kings $11: 28$}

A connection between the bet-yosef and the ratification of kingship is also evident in 1 Kings 11:28. Here, in recognition of Jeroboam ben Nebat's capability as a worker, Solomon appoints him "over the all the forced labor of the House of Joseph" (הוא ויפקד אתו לכל־סבל בית־יוסף). Mordechai Cogan takes this as a refer-

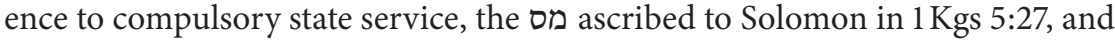
concludes that if the state corvée was organized on the basis of the twelve-district system, as were the other taxes, then the term "House of Joseph" refers to the district of Mount Ephraim referred to in $1 \mathrm{Kgs} 4: 8$, not to the dispersed Joseph tribes as a whole. ${ }^{25}$ Like the glossator in Josh 17 , Cogan here assumes a false equivalency between the bet-yosef and binai-yosef allowing them to connect the bet-yosef of $1 \mathrm{Kgs} 11$ to har-Ephraim of $1 \mathrm{Kgs} 4$, though this equation is never made by the biblical authors. Furthermore, they treat the מס of 1 Kgs 5 as equivalent to the סבל $1 \mathrm{Kgs} \mathrm{11}$, assuming that both refer to the imposition of Solomon's administrative apparatus, though again, the biblical authors themselves do not appear to be making this connection, either linguistically or narratively.

The closest parallel to the phrase סבל בית־יוסף is in Exod 6:6-7, where God promises to bring Israel out from under סבלות מצריים, "the burdens of Egypt."

${ }^{6}$ Therefore, say to the Israelites: 'I am Yahweh, and I will bring you out from under the burdens of the Egyptians (סבלות מצריים). I will free you from being slaves to them, and I will redeem you with an outstretched arm and with mighty acts of judgment. ${ }^{7}$ And I will take you to myself as a people, and I will be to you as gods and you will know that I am Yahweh, your god, who brought you out from under the burdens of Egypt' (מוציא אתכם מברו (מתחת סבלות מצרים).

Based on the Exodus text, the implication of $1 \mathrm{Kgs} 11$ is not that the bet-yosef was affected by Solomon's harsh administrative policies, rather it was in a position of dominance, imposing, not bearing כל סבל. If this seems odd, we need only think

${ }^{25}$ M. Cogan, I Kings, (AB 10; New York: Doubleday, 2001), 339. 
of Joseph himself, in Gen 41, whom Pharaoh places over all Egypt, ויצא יוסף על ארץ מצריים, "and Joseph went out over the land of Egypt” (Gen 41:45). The idea that this is an expression of dominance is often missed in English translations of the identical expression in Ps 81:6: "He imposed it as a decree upon Joseph, בצאתו על ארץ מצריים.” Translators tend to either follow the ancient versions and render either along the lines of, "when he went forth from the land of Egypt,"26 which brings the verse into alignment with the Exodus tradition; or they maintain the MT, but render, "when he went out against Egypt." ${ }^{27}$ While the second translation is technically correct, it maintains the notion of an adversarial relationship between Joseph and Egypt that is at odds with the Joseph story itself, and with Gen 41:45 in particular, where Joseph is fully integrated into and in a position of power within the Egyptian bureaucracy. Based on this, we may conclude that when Solomon appoints Jeroboam over סבל בית־יוסף, Jeroboam assumes leadership of an entity that already held a position of power in the land. In this way, a parallel may be drawn between the bet-yosef in Canaan and "Joseph the Hebrew" in Egypt. The verse is concerned with something altogether different from the references to taxes and state-mandated labor imposed by Solomon in $1 \mathrm{Kgs} \mathrm{4-5}$. The representation of Jeroboam as assuming control over the betyosef pertains to and foreshadows the transfer of power from Solomon to Jeroboam. Much as the bet-yosef in 2 Sam 19 was essential in legitimating David's rule over and against Saul's, in 1 Kgs 11 it bestows legitimacy upon Jeroboam just as Solomon is about to fall from grace. There may, in fact, be an implicit critique of Solomon, that an ancient audience would have been attuned to, in his placement of control of this particular entity in someone else's hands. Jeroboam's acceptance of this responsibility would have been the first step in ratifying his own authority over the Israel he would come to rule.

\subsection{Judges 1:34-35}

The final instance I will discuss of the bet-yosef in a position of dominance, here in a pre-monarchic setting, appears in Judg 1:34-35. After a list of towns that the Israelite tribes failed to dispossess (לא הוריש), we find this notice, "The Amorites pressed the b'nai dan towards the hill country, for they did not allow them to come down into the valley. The Amorites undertook to settle in Har Heres, Ajalon, and Shaalbim, but the hand of the bet-yosef was heavy and they became forced labor." The b'nai dan are treated here as separate from the tribal groups named in the preceding לא הוריש list. By relegating the Amorites to the status of

\footnotetext{
${ }^{26}$ E.g., KJV, NKJ, NAB, TNK. The LXX and Peshitta replace the preposition מל with, correcting the lectio difficilior of the MT.

${ }^{27}$ E.g., NIB, NIV, NJB. Also F. L. Hossfeld and E. Zenger, Commentary on Psalms 51-100 (2nd ed.; ed. E. Zenger et al.; Minneapolis, MN: Fortress Press, 2005), 319-320. The RSV and ESV are exceptions, translating correctly, in my view, "When he went out over the land of Egypt."
} 
"forced labor" (היה למס) the bet-yosef comes to the aid of the b'nai dan against the territorial ambitions of the Amorites. Though Judg 1 is widely regarded as a late, Judahite (re)introduction to the book of Judges ${ }^{28}$ I would suggest that reference to the imposition of מס on the Amorites by the bet-yosef in v. 34-35 may preserve the memory of an old, pre-monarchic geopolitics. ${ }^{29}$ The dynamics and language of Judg 1:34-35 may have informed the presentation of the לא הוריש list in the preceding verses, and in particular, repetition of the היה למס formula.

The bet-yosef of Judg 1:34-35 is presented as an entity that pre-existed the establishment of the monarchy and that could exercise its political will in cooperation with or opposition to other groups. In this case, it acts in cooperation with the b'nai dan against the Amorites; it appears to be in a position to police the interactions between these two groups and to dominate in the Shephelah lowlands. Though we receive this tradition filtered through the hands of late Judahite authors and editors, and though it is difficult to know how place-names and interactions might have been modified to reflect later interests, the encounter between the Amorites, the b'nai dan and the bet-yosef may be illuminated by letters in the Amarna archive sent between Egypt's vassals and dependents scattered throughout Syria-Palestine and the Egyptian king.

\section{The bet-yosef and the Amarna Period Levantine Socio-Political Landscape}

In his reassessment of the socio-political categories attested in the Egyptian Amarna archive, Brendon C. Benz demonstrates that in the Late Bronze and Iron I periods, the landscape of the southern Levant was characterized by a wide variety of socio-political experiences. ${ }^{30}$ These included: cities with political will executed by a single leader, or hazannu; centralized lands, characterized by a high degree of centralization under an administrative complex located in a single urban center under the authority of a single individual; and multi-polity, decentralized lands, comprised of a political coalition of cities and centralized lands

${ }^{28}$ See for example, M.Z. Brettler, The Book of Judges (London: Routledge, 2002), 96102; W. Gross, Richter (Freiburg i. Br.: Herder, 2009), 91-94. R. O'Connell, The Rhetoric of the Book of Judges (Leiden: Brill, 1996), 58-80; M. Sweeney, "Davidic Polemic in the Book of Judges," VT 47/4 (1997), 526-527. On the practice of "revision through introduction" more broadly, see S. Milstein, Tracking the Master Scribe: Revision through Introduction in Biblical and Mesopotamian Literature (New York: Oxford University Press, 2016).

${ }^{29}$ For a recent, thorough discussion of the Amorites with bibliography, see D. Fleming, "The Amorites", in The World Around the Old Testament: The People and Places of the Ancient Near East (ed. B.T Arnold and B. Strawn; Grand Rapids, MI: Baker Academic, 2016), 1-30.

${ }^{30}$ B. C. Benz, The Land before the Kingdom of Israel: A History of the Southern Levant and the People Who Populated It (Winona Lake, IN: Eisenbrauns, 2016). 
that retained their independence under the authority of their respective leaders. ${ }^{31}$ Some multi-polity decentralized lands were inimical to Egypt and its interests, as in the case of Amurru, while others, most notably Canaan, consisted of entities that aligned themselves politically with Egyptian interests.

Benz suggests that the multi-polity decentralized land is the most appropriate category for understanding the Kingdom of Labayu (which included Shechem, and which is the primary focus of his study) as well as Israel's political organization before the formation of the monarchy. ${ }^{32}$ Implicit in this idea is that patterns that were established in the context of Late Bronze Age Egyptian hegemony continued to shape the socio-political landscape of Syria-Palestine in the centuries after Egyptian power had waned. Benz makes this explicit in his treatment of Judg 9, where he finds the strongest evidence for this continuity. ${ }^{33}$ I would suggest that the representation of the bet-yosef in Judg 1:34-35 has its roots in the same socio-political world as Judg 9 as Benz understands it. Furthermore, like earliest Israel, the bet-yosef as it is attested especially in Judg 1:34-35, but also in 2 Sam 19 and $1 \mathrm{Kgs} 11$, may be best understood in terms of Benz' "multi-polity decentralized land" category. ${ }^{34}$ Several of Benz' observations are noteworthy.

First, he observes that, because the constituents of multi-polity decentralized lands retained their independence, this form of organization provided some level of political unity without threatening locally embedded sources of identity and authority. ${ }^{35}$ This might help to explain Shimei's self-identification as both "the "ראשון לכל-בית יוסף "this tribal and town identity) and הן הימיני אשר מבחורים first of the entire house of Joseph" to come down to meet the king. Shimei's tribal and town identity are in no way eclipsed by or at odds with his association with the bet-yosef; rather as a Benjaminite from Bahurim he represents only one element within the multi-polity collective (the עם רב of Judg 1) called the bet-yosef. That he is a Benjaminite and a Saul loyalist might have made his constituency's endorsement particularly important in the transfer of power from Saul to David.

Second, Benz notes that though the authors of the Amarna letters were often consumed by military concerns, the multi-polity decentralized land did not exist solely for mutual protection against a common enemy, but also for other nonmartial, corporate activities, such as agricultural production. ${ }^{36}$ In support of this he cites Amarna Letter EA 365, in which Biridiya, the hazannu of Megiddo, and member of the multi-polity, decentralized land of Gina, issues a complaint that he alone has furnished the necessary corvée workers to cultivate the land around

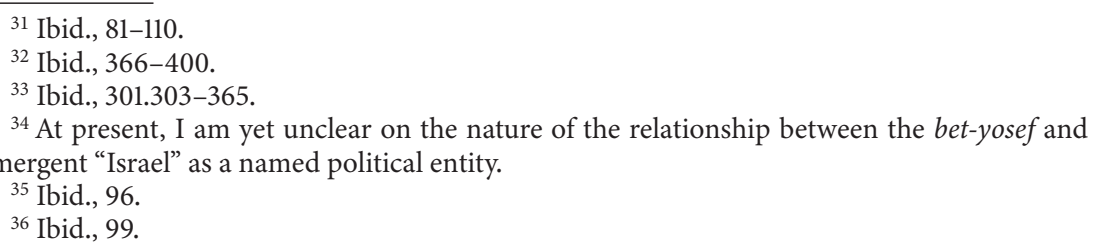


Šnama. He accuses the other hazannuti of not doing the same. Nadav Na'aman identifies Gina as the name by which the entire Jezreel Valley was known during the Amarna Period in Egypt, and both Moran and Rainey identify Šunama as biblical Shunem. ${ }^{37}$ Implicit in this letter is the idea that all of the members of the multi-polity, decentralized land, to which Biridiya belonged were responsible for providing corvée labor for the cultivation of lands under Egyptian control. Biridiya and his constituency are both aligned with and actively involved in the administration of these Egyptian interests.

Reference to corvée labor in this letter is designated by the Akkadian massu, cognate to the Hebrew term imposed on the Amorites by the bet-yosef in Judg 1:34-35. The idea that the administration of corvée labor was one of the expectations of a multi-polity decentralized land might help to explain the expression סבל בית־יוסף "all the forced labor of the house of Joseph" in 1 Kgs 11. On analogy with the corvée of EA 365, סבל בית־יוסף would connote labor forces administered by the bet-yosef, control of which now fell to Jeroboam.

If there is merit to the idea that the bet-yosef in these texts constitutes an entity that somehow continued to occupy a space in the socio-political landscape of Syria-Palestine in the wake of Egyptian domination, Jeroboam's flight directly to the Egyptian king Shishak in 1 Kgs 11:40 and his residency in Egypt until the death of Solomon takes on greater significance. The biblical authors may have regarded Jeroboam's association with and oversight of the bet-yosef as having tied him to Egypt, easing movement between his base in Shechem and the Pharaonic court. If this is the case, it points to the possibility that, at least within biblical memory, some of the infrastructure of Egyptian hegemony in the region remained, at least into the tenth century, represented in part by the bet-yosef.

Historians of ancient Israel have tended to emphasize Late Bronze Age collapse as a primary factor in the emergence of ancient Israel, ${ }^{38}$ a hypothesis that once found support in archaeological evidence of decreased contact between Egypt and Canaan as the New Kingdom came to its end. ${ }^{39}$ However, the Bible itself de-

${ }^{37}$ W. L. Moran, The Amarna Letters (Baltimore, MD: Johns Hopkins University Press, 1992), 392; N. NA'AMAN, "Pharaonic Lands in the Jezreel Valley in the Late Bronze Age," in Canaan in the Second Millennium BCE (ed. N. Na'aman; Winona Lake, IN: Eisenbrauns, 2005), 238-239; A. F. RAIney and W.M. SchNiedewind (ed.), The El-Amarna Correspondence: a New Edition of the Cuneiform Letters from the Site of El-Amarna based on Collations of All Extant Tablets (Leiden: Brill, 2015).

${ }^{38}$ W. G. Dever, Who Were the Early Israelites, and Where Did They Come From? (Grand Rapids, MI: Eerdmans, 2003); A. FAust, Israel's Ethnogenesis: Settlement, Interaction, Expansion and Resistance (London: Routledge University Press, 2014); A. H. Joffe, "The Rise of Secondary States in the Iron Age Levant," JESHO 45/4 (2002), 425-467; O. SERGI, "State Formation, Religion and 'Collective Identity' in the Southern Levant," HBAI 4/1 (2015), 56-77.

${ }^{39}$ D. B. Redford, "Studies in Relations between Palestine and Egypt during the First Millenium B. C.: II. The Twenty-Second Dynasty," JAOS 93/1 (1973), 3-17; IDEM, Egypt, Canaan, and Israel in Ancient Times (Princeton, NJ: Princeton University Press, 1993); J. M. WeInstein, "Egyptian Relations with the Eastern Mediterranean World at the End of the Second Millennium 
scribes on-going relations between Egypt and Israel, and there is ample evidence for their shared literary and scribal culture, as Bernd Schipper and others have demonstrated. ${ }^{40}$ Furthermore, Shirly Ben-Dor Evian, Aaron Burke, and others are demonstrating that the archaeological picture is changing to reveal on-going relations between Egypt and Levant during the early Iron Age. ${ }^{41}$ I would suggest that the bet-yosef texts I have analyzed here can be added to the growing body of evidence for limited continuity between the Late Bronze and Iron Age in SyriaPalestine. Rather than understand Israel as having emerged in the vacuum of Egyptian hegemony, as has traditionally been assumed, we might think of some of the residual structures of the Egyptian administrative system to have provided emergent Israel with a blueprint for its own becoming.

With these observations in mind, I now turn my attention from Jeroboam and his milieu, back to our other Yahweh-worshipping refugee in Pharaoh's court, Joseph himself. I shall suggest that underlying the story of "Joseph ben Jacob," is a yet earlier version of the Joseph story, concentrated primarily in Gen 39-41, which features Joseph alone with no brothers and no explicit connection to Canaan other than his identification as an 'ivri in the land of Egypt. I will argue that this self-contained story of a Hebrew servant who rises to the rank of second-in-command to Pharaoh himself, constitutes the oldest material in the Joseph story. The literary priority of "Joseph the Hebrew" to the larger account of "Joseph ben Jacob" and the incorporation of the former into the latter point to a different, arguably earlier, social horizon for the "Joseph the Hebrew" story. The idea that the Jacob/Israel family saga is built on the foundation of an earlier

BCE," in Mediterranean Peoples in Transition: Thirteen to Early Tenth Centuries BCE (ed. S. Gitin et al.; Jerusalem: Israel Exploration Society, 1998), 188-196.

${ }^{40}$ B. U. Schipper, "Egypt and Israel: The Ways of Cultural Contacts in the Late Bronze Age and Iron Age (20th-26th Dynasty)," Journal of Ancient Egyptian Interconnections 4/3 (2012), 30-47; W.M. Schniedewind, A Social History of Hebrew: Its Origins through the Rabbinic Period (New Haven, CT: Yale University Press, 2013); K. van Der Toorn, Scribal Culture and the Making of the Hebrew Bible (Cambridge: Harvard University Press, 2007).

${ }^{41}$ A. Burke, "The Decline of Egyptian Empire, Refugees, and Social Change in the Southern Levant, ca. 1200-1000 вс," in An Archaeology of Forced Migration: Crisis-induced mobility and the Collapse of the 13th c. BCE Eastern Mediterranean (ed. Jan Driessen; Leuven: Presses Universitaires de Louvain, 2018), 235-255; IDEM et al., "Excavations of the New Kingdom Fortress in Jaffa, 2011-2014: Traces of Resistance to Egyptian Rule in Canaan," AJA 121/1 (2017), 85133; S. BEn-Dor Evian, "Egypt and Israel," NEA 80/1 (2017), 30-39; IDEM, "Shoshenq I and the Levant: Synchronising Chronologies," in Solomon and Shishak, Current Perspectives from Archaeology, Epigraphy, History and Chronology. Proceedings of the Third BICANE Colloquium Held at Sidney Sussex College, Cambridge 26-27 March 2011 (ed. P. James and P. G. van der Veen; BAR International Series 2732; Oxford: BAR, 2015), 17-19; IDEM, "Amun-of-the-Road: Trade and Religious Mobility between Egypt and the Levant at the Turn of the First Millennium вCE," WO 47/1 (2017), 52-65. Also relevant in this regard is Finkelstein's designation "New Canaan" to describe continuity with the preceding period in the material culture of Iron I lowland settlements. I. Finkelstein, "City States and States: Polity Dynamics in the 10th-9th Centuries B. C. E.," in Symbiosis, Symbolism and the Power of the Past: Canaan, Ancient Israel, and their Neighbors (ed. W. G. Dever and S. Gitin; Winona Lake, IN: Eisenbrauns, 2003), 75-83. 
Joseph ancestor tradition raises the question, if Jacob is "Israel," who was Joseph? For whom was this figure important, among those who later call themselves "Israel." What did his name and story connote? I will suggest that "Joseph the Hebrew" is best understood as an eponymous ancestor of the bet-yosef, the political entity that bore his name, and that gave shape to Israel before the idea of Israel as the house of Jacob held currency.

\section{Unearthing "Joseph the Hebrew"}

Gen 39:2-41:54a and some of 47:14-23 constitute a self-contained story of a certain Hebrew by the name of Joseph whose rare combination of wit, good fortune and divine inspiration lead him from servitude in his Egyptian master's house to a position as overseer of the whole land of Egypt. These three chapters teem with people, nameless courtiers of the Pharaoh, who serve as foils for Joseph's ascent.

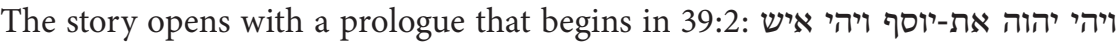
מצליח ויהי בבית אדניו המצרי. "Yahweh was with Joseph; he was a successful man; he lived in the house of his Egyptian master"; and ends in 39:6: ויהי יוסף יפה-תאר "Joseph was beautiful of form and appearance," a detail that sets up the advances by his master's wife in 39:7 ff. Joseph's master takes a liking to him precisely because Yahweh was with him (explicit in 39:3-4), and puts Joseph in charge of his household, placing all that he owns in Joseph's hands. When Joseph is falsely accused of raping his master's wife and lands in prison, Yahweh remains with him $(39: 21,23)$ so that the chief-jailor extends him kindness and leaves all of the prisoners in his capable hands (39:22). The appointment of Joseph over households and people is a leitmotif in this self-contained story, in which Joseph effectively and systematically replaces the Egyptians in power.

Though I understand Gen 39-41 to have originated as an independent literary work, I do not regard this composition as having been produced of whole cloth. I share Römer's sense that Joseph's encounter with Potiphar's wife is an independent Joseph tradition, either modeled on or shaped by the same influences as the Egyptian New Kingdom text, the Tale of Two Brothers. ${ }^{42}$ In fact, Gen 39-41 may consist of several independent Joseph traditions that provided the building blocks for the "Joseph the Hebrew" story, much as the Old Babylonian Gilgamesh epic was composed from independent Sumerian Gilgamesh vignettes. Among these independent traditions might have been at least one story of Joseph, interpreter of dreams, as well as a story of Joseph the benevolent administrator in Pharaoh's court, who provisioned Egypt during a time of famine. If the pos-

${ }^{42}$ T. Römer, "Joseph and the Egyptian Wife (Genesis 39): A Case of Double Supplementation," in Supplementation and the Study of the Hebrew Bible (ed. S. M. Olyan and J.L. Wright; BJS 361; Providence, RI: Brown Judaic Studies, 2018), 69-83. 
sibility of originally independent Joseph traditions in Gen 39-41 holds up to text historical scrutiny, it would lend support to the idea of Joseph as an independent ancestor.

Several details in Gen 39-41 set it apart from the surrounding narrative. For example, there is no reference to herding as Joseph's mode of economic subsistence, a characterization that is essential to Gen 37 and the larger Jacob narrative. Famously, Gen 39 refers to Joseph's master; however, the name Potiphar appears to be an invention of the scribes who produced Gen 37. As such it provides a necessary bridge between the world occupied by Joseph's brothers in Canaan and the household in Egypt where he is a servant. Reference to Potiphar in 39:1 echoes the conclusion of Gen 37, where Potiphar purchases Joseph from the Midianite traders in Egypt. Together, these two references bracket the insertion of the Judah and Tamar story in Gen 38. The "Joseph the Hebrew" story thus begins in earnest in 39:2. ${ }^{43}$ Gen 42:6 identifies Joseph as שליט or "vizier." This term is absent from the account of his rise to power in 39-41, where he is placed over his master's house, the jailhouse, the house of Pharaoh and finally over all the land of Egypt (41:41), all expressed by the preposition על, "to be over." Finally, while Genesis 39-41 cast Joseph in an entirely positive light, as one whose divinely granted wisdom and discernment warranted his appointment as second in command of all of Egypt, his brothers' incredulity upon hearing his dreams, their chiding, and his father's' rebuke, call his elect status into question. This diminishing of Joseph in Gen 37 may be part and parcel of a shift from Joseph as an independent ancestor with his own associations to Joseph as a single brother among twelve, to accommodate a more expansive, Greater Israelite monarchic definition of Israel.

The old Joseph alone story is revised by introduction, a mode of scribal intervention identified by Milstein in her work on the composition of the book of Judges, ${ }^{44}$ so that Gen 37 with its story of young Joseph the dreamer becomes the new starting point for a narrative about how Israel, defined as the twelve sons of Jacob, came to reside in Egypt. This new introduction reorients the core Joseph story and conditions the way we read the revised account that follows. The story of "Joseph ben Jacob" that begins in Gen 37 resumes in Gen 42.

In order to incorporate a Canaan-based Jacob tradition into an extant, Egyptbased Joseph tradition, v. 41:54b-57 and 47:13 expand the famine to include not just Egypt, but "all lands" including Canaan. ${ }^{45}$ These verses create brackets around the inserted story of Joseph's reunion with his brothers, in Gen 42-47:12,

${ }^{43}$ The choice of the name Potiphar in Genesis 37 may have been conditioned by the more properly Egyptian name Potiphera, or P3-di-p3-R', which Redford translates "he whom Re gives", whose daughter Joseph marries in Gen 41:45.

${ }^{44}$ Milstein, Tracking the Master Scribe (see n. 28).

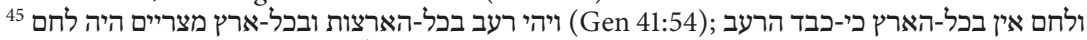
מאד ותלה ארץ מצריים וארץ כנען מפני מצרים הריה לחם (Gen 47:13). 
and allow for the movement of the brothers from Canaan to Egypt. References to famine in Canaan are at odds with details in Gen 39-41 and 47:15-26 that indicate famine in Egypt alone. For example, when Joseph interprets Pharaoh's dreams in 41:29-30, he predicts "seven years of great abundance will be in all the land of Egypt" (בכל-ארץ מצרים), followed by seven years of famine, when "all the abundance in the land of Egypt will be forgotten." Similarly, in 47:15b, the Egyptians alone come to Joseph asking for bread and when Joseph provisions the Egyptian people while concentrating all of Egypt's wealth in the hands of Pharaoh, there is no reference to the "land of Canaan".

A remnant of the original conclusion of the "Joseph the Hebrew" story may be preserved in Gen 47:25 where the Egyptians declare, "We have found favor in the eyes of (our) lord and will be servants to Pharaoh" (עבצא-חן בעיני אדני והיינו).

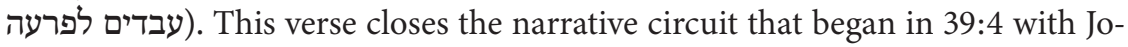
seph who "found favor in his master's eyes and served him" (וימצא יוסף חן בעיניו (וישרת אתו (ויש מצליח 4ith fulfilled, his journey from servant to master completed, his position of dominance established. At the same time, as 47:25 may preserve traces of an original ending, taken as a whole, 47:14-24 and 26-27, is unlikely to be original to either the old core tradition or to the story of "Joseph ben Jacob." These verses feature an entirely different Joseph from either the naïve dreamer we meet in Gen 37 or the wise and benevolent administrator who is the hero of 39-41, and are likely to constitute a late addition. Gen 47 presents a Joseph who outfoxes the Egyptians, extracting from them their money, their land, and eventually their servitude. Whereas in Gen 41:47-48 Joseph provides for each city by storing up its grain, in Gen 47 he sells rations that he has personally acquired, building up wealth in the hands of Pharaoh, taxing his people and leaving them entirely dependent. The note in 47:26 that Joseph instituted a one-fifth tax and made this a land law in Egypt for everyone but the priests, constitutes an odd ending to the "Joseph the Hebrew" tale. Yet these verses share with Gen 39-41 a Joseph who has no apparent connections to Canaan, or to Jacob and his sons. Furthermore, as in Gen 39-41, Joseph stands in a position of power over Egypt, acting in an administrative capacity, though here in a more insidious representation of imperial power. If indeed Gen 47:1424 constitute a later addition, it suggests that even after the integration of Joseph into the family of Jacob and the establishment of this more expanded narrative tradition, the idea of "Joseph the Hebrew" who rose to power in a foreign court still held currency, perhaps now in a diaspora setting. ${ }^{46}$

\footnotetext{
${ }^{46}$ Two other details in Gen 39-41 are likely to be late, diaspora period additions to the canonical Joseph story. The first is reference to Joseph's marriage to Asenath in Gen 41:45 and the birth of his children, Ephraim and Manasseh, who at once tie Joseph to a Canaan-based biblical vision of tribal Israel, while at the same time, provocatively, distancing him from that system. The second is Joseph's lament in prison גנב גנבתי מארץ העברים, "Truly, I was carried off from the land of the Hebrews". This verse is the only instance in Genesis 39-41 where Joseph's experi-
} 
Joseph's identity as an 'ivri is crucial to understanding the interests of the authors who produced Gen 39-41. Naaman notes that this designation often appears in the Bible in unfavorable contexts. With the integration of "Joseph the Hebrew" into the larger "Joseph ben Jacob" story, the identification of Joseph as "ivri does come to connote alienation and dejection in Egypt. However, references to Joseph as an 'ivri in Gen 39-41, with one exception, are entirely neutral, and this in itself may point to an earlier social horizon for the "Joseph the Hebrew" story. The origins of the term "ivri and its possible connection to the 'apiru, known from the archives of Ugarit, Alalakh, and Amarna, is a long-standing problem in biblical studies, with a copious literature. ${ }^{47}$ Fleming notes that while the 'apiru provide no direct link to Israel as either vocabulary or as a social entity, several texts from the early second millennium, before the term 'apiru became a fixed type, attest a verb that appears to be cognate with the noun, without being simply denominative. ${ }^{48}$ The verb always has to do with departure from one's home to take up residence in a different place, especially a different political entity. In the two Mari letters Fleming sites ${ }^{49}$ the verb is applied to an individual who has moved either to or from a town where he was a relative outsider. The Mari evidence includes two nouns derived from this root, a G participle ' $a b$ / pirum, "one who leaves/moves away;" and the noun 'ib/prum, designating the mobile community of the Yaminite herdsmen at distance. The second noun is much rarer, not evidently becoming part of the general regional terminology, but matching the word 'ivri exactly. ${ }^{50}$ It is worthwhile to note that the identification of Joseph as an 'ivri in Gen 39-41 is consistent with attestations of the verbal root at Mari, in its application to a single individual who has moved away from home and taken up residence elsewhere. It connotes mobility not defined by alienation or exile. Connections to use of the term 'ibrum at Mari offer no basis for dating the "Joseph the Hebrew" tradition; however they do point to an understanding of the term that is both natural to the Syro-Palestinian landscape and uncolored by notions of bondage or suffering that inform the Bible's larger narrative of Israel in Egypt.

ence in Egypt is tied to notions of coercion and dejection. Furthermore, reference to a "land of the Hebrews" is unique in the Bible, and is likely to reflect a late-period ethnic association for the term עברי. See the more detailed discussion of this term below. At the same time, the passive construction גנב גנבתי may reflect a diaspora interest in Joseph's movement to Egypt without the agency of brothers in Canaan, even after the integration of Joseph into the family of Jacob. I am grateful to Ted Lewis (personal communication) for pointing this out to me.

${ }^{47}$ See Fleming, "Amorites" (see n. 28), 23-26, with additional bibliography in IDEM, The Legacy of Israel in Judah's Bible: history, politics, and the reinscribing of tradition (New York: Cambridge University Press), 264-269.

${ }^{48}$ Ibid., 264.

${ }^{49}$ ARM 27.116,31-32 and ARM 28.46,2'-8'.

${ }^{50}$ D. Fleming, personal communication. 
For the bet-yosef, Joseph's identification as an 'ivri would have been essential, as it provides him with ties to both Egypt, where he is completely at home, and a home in another political arena. "Joseph the Hebrew" and Jeroboam would have had this in common, though the word "ivri is never used in reference to the would-be king. Tracing its origins to a Yahweh-worshipping 'ivri who rose to power in Egypt would have provided the bet-yosef with a myth of legitimation for its position of dominance in Canaan.

\section{Conclusion}

To return to where we began, in the saga of Jacob and his sons that concludes the book of Genesis, Joseph is distinct among his brothers. Though diaspora interests lend shape to the canonical Joseph story, beneath the surface of this literary masterpiece lies "Joseph the Hebrew, an איש מצליח, with no brothers or explicit connection to Canaan, whom Yahweh set on the path to greatness. I have proposed here that this Joseph was ancestor to the bet-yosef, a political entity that appears to have held a position of power in the central highlands of Canaan in the pre- and early monarchic period.

In his discussion of multi-polity, decentralized lands, Benz observes that, "Under the right conditions, a multi-polity, decentralized land could transform into a centralized land under the leadership of a single individual who administered the entire complex from his royal center." 51 Shimei's acceptance of David's rule, as well as Jeroboam's appointment over the labor forces of the bet-yosef might preserve memories, however hazy, of integration of the bet-yosef and Israel's rule by kings. 2 Sam 19 and 1 Kgs 11 recall the bet-yosef as foundational in the establishment of the Israelite monarchy. The latter may have absorbed and overshadowed the former, as part of the formation of Greater Israel. The Bible's occasional use of the name bet-yosef in reference to the northern kingdom may preserve a memory of this old geopolitical development. On a literary level, as Israel was re-envisioned as a tribal collective with full geographic coverage, Jacob as Israel absorbed and replaced Joseph, at once preserving and obscuring Joseph's formative role in the genesis of ancient Israel.

${ }^{51}$ Benz, Before the Kingdom of Israel (see n. 30), 97. 



\title{
Aspects of Jewish Identity in the Joseph Story
}

\author{
Samuel Arnet
}

The Joseph story handles key issues within the Hebrew Bible rather idiosyncratically, especially means of revelation and relationships that mould communities' self-definitions. While some passages explicitly forbid marriages between Hebrew and non-Hebrew individuals, Joseph marries an Egyptian woman. While certain passages condemn divination, Joseph practises it. While Egypt, especially Pharaoh, is often portrayed negatively, Egypt is portrayed as friendly towards the family of Jacob. Finally, Joseph's receiving a new name differs from other acts of re-naming in the Hebrew Bible. Through each of these elements, the Joseph story appears to participate in constructing a post-exilic Jewish identity with sociologically and theologically porous boundaries.

\section{Attitudes towards Mixed Marriages}

Marriages or unions between Hebrew and non-Hebrew individuals are mentioned on several occasions in the Bible. In the book of Genesis, Esau's two wives who "were a source of grief to Isaac and Rebekah" were Hittites (Gen 26:35; cf. 27:46), Judah's daughter-in-law Tamar who gave birth to their twin sons Perez and Zerah was Canaanite (Gen 38:27-30); and Jacob's son Simeon had a son with a Canaanite woman (Gen 46:10). In the book of Exodus, indigenous women are depicted as a source of apostasy (Exod 34:15-16), and this is illustrated, among other texts, through the incident at Shittim in the book of Numbers (Num 25:1-2). Because apostasy is seen as a consequence of intermarriage, it is strictly forbidden in the book of Deuteronomy and elsewhere (e.g., Deut 7:3-4). ${ }^{1}$

A prominent example of intermarriage causing apostasy is found in the first book of Kings with the mention of the Egyptian princess whom King Solomon married (1 Kgs 3:1; 7:8; 9:16, 24). Their relationship is first reported a few verses before Solomon's dream at Gibeon, where he is commended by God (3:511). Later, however, Solomon loved "many foreign women besides Pharaoh's

\footnotetext{
${ }^{1}$ Examples include Jos 23:12-13; Judg 3:5-6; 1 Kgs 16:30-31; Ezra 9:1-2; 10:18-44. See C. Frevel and B.J. Conczorowski, "Deepening the Water: First Steps to a Diachronic Approach on Intermarriage in the Hebrew Bible," in Mixed Marriages. Intermarriage and Group Identity in the Second Temple Period (ed. C. Frevel; LHB 547; London: T\&T Clark, 2011), 15-45.
} 
daughter - Moabites, Ammonites, Edomites, Sidonians and Hittites ... who led him astray [and] turned his heart after other gods [so that] his heart was not fully devoted to the LORD his God," and this resulted in YHWH becoming "angry with Solomon" (1 Kgs 11:1, 3-4, 9).

However, in the Joseph story, we read that Pharaoh gave Joseph "Asenath daughter of Potiphera, priest of On, as his wife" (Gen 41:45), and this relationship is not criticized. Of Joseph's Egyptian wife Asenath we only know her name, the name and function of her father, and that she became the mother of Joseph's two sons (Gen 41:50). All this is stated in a straightforward way, and it is literarily unadorned - no further incidents involving her are reported. ${ }^{2}$ The reader is simply presented with the information that the Hebrew man Joseph married an Egyptian woman - presumably because in Egypt, Joseph was the only Hebrew, and there was no Hebrew woman for him to marry. The names of Joseph's two sons - Ephraim and Manasseh - are again mentioned alongside the phrase that they were Joseph's sons "by Asenath daughter of Potiphera, priest of On" (Gen 46:20), and in the last verses of the Joseph story, it is stated that they in turn had children as well (Gen 50:23). So, in a sense, away from his homeland and his people, Joseph did in Egypt what Jeremiah, in his letter, asked the exiles in Babylon to do: "Marry and have sons and daughters; find wives for your sons and give your daughters in marriage, so that they too may have sons and daughters. Increase in number there, do not decrease" (Jer 29:6).

Joseph's marrying a non-Hebrew woman abroad may also be compared to the Judahite couple Elimelekh and Naomi, whose two sons in Moab married the Moabite women Orpah and Ruth (Ruth 1:1-4). Here too, the text voices no criticism about these marriages. On the contrary, after these two Moabite women had become widows, Ruth returned with her mother-in-law to Bethlehem in Judah (1:5, 22), where she married Boaz, a relative of her deceased father-in-law $(2: 1 ; 4: 13)$. So, in the book of Ruth, two male relatives of Elimelekh sequentially marry Ruth the Moabite, who through her son Obed becomes the ancestor of King David $(4: 17,22)$. In the Joseph story, Joseph and Asenath become parents of Ephraim and Manasseh, whose tribes will later be part of the Northern kingdom of Israel. In both texts, the issue of apostasy is somewhat irrelevant. True, Joseph's fatherin-law was the priest of On (א), which the Septuagint translators identified with Heliopolis, a cult center where the sun god was worshipped, but there is no indication whatsoever to conclude that the presence of this Egyptian priest in Joseph's family led him or his wife to "forsake the LORD." Neither is such a form of apostasy reported in the book of Ruth; in fact, in this story, no other deity is mentioned but YHWH, most often by Naomi and Boaz, ${ }^{3}$ and once even by Ruth

\footnotetext{
${ }^{2}$ Contrast this with the incident involving Potiphar's wife in Gen 39:7-18.

${ }^{3}$ Naomi: Ruth 1:8, 9, 13, 21; 2:20; Boaz: Ruth 2:4, 12; 3:10, 13. Ruth 1:20, 21 has Naomi also mention Shaddai, but this presumably refers to no other deity than YHWH.
} 
herself (Ruth 1:17). ${ }^{4}$ So, while in general intermarriage is seen critically in the Bible, there are notable exceptions, as is the case in the Joseph story.

\section{The Practice of Divination}

In their attempt to predict future events, diviners either use external means (deductive divination), or they rely on their own awareness (inductive divination). ${ }^{5}$ In the Hebrew Bible, a well-known example of the latter is oneiromancy (divination by interpreting dreams), and examples for the former include belomancy (divination by means of arrows), hepatoscopy (divination by examination of the liver of an animal), and astrology (interpretation of the motions of celestial bodies). ${ }^{6}$

Joseph is noted for his ability as a dream-interpreter and is thus depicted as a practitioner of inductive divination. Less well-known is the fact that he is also depicted as a practitioner of deductive divination, albeit only in one or two short passages. In Genesis 44, he is described as using a goblet for divination (lecanomancy): ${ }^{7}$

They had just left the city and had not gone far, when Joseph said to his steward, "Up, go after the men! And when you overtake them, say to them, "Why did you repay good with evil $?^{8}$ [The silver goblet] ${ }^{9}$ is the very one from which my master drinks and which he uses

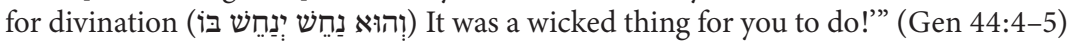

This statement is repeated in similar words a few verses later when Joseph's brothers return to his house:

\footnotetext{
${ }^{4}$ Interestingly, in the course of the narrative, Ruth is compared to Rachel and Leah, "who built up the family of Israel" (Ruth 4:11), and Obed is compared to Perez, "whom Tamar bore to Judah" (4:12). This way, the story of Ruth creates links to the Joseph story - to Joseph's mother Rachel and to his brother Judah.

${ }^{5}$ See A. LAnge, "Divination (AT)," Das wissenschaftliche Bibellexikon im Internet, https:// www.bibelwissenschaft.de/stichwort/16521/. Accessed 01/25/2021.

${ }^{6}$ For biblical references, see, e.g., S. Ạ̣ıṬuv, "Divination," Encyclopaedia Judaica (2nd ed.; ed. F. Skolnik and M. Berenbaum; Jerusalem: Keter, 2007), 5.703-705, here 704-705.

${ }^{7}$ B. LANG, "Joseph the Diviner: Careers of a Biblical Hero," in Hebrew Life and Culture: Selected Essays of Bernhard Lang (ed. B. Lang; MSSOTS; Farnham: Ashgate, 2008), 93-109, assumes that "in one version of the tale, the cup's divinatory function actually served some critical purpose. The relevant episode may have been known to early readers of Genesis; for us, however, it is lost", here 96.

${ }^{8}$ The Septuagint has another question after this one: "Why did you steal my silver cup?" It appears to be an addition explaining what was missing in the Hebrew Vorlage ("Die Erzähllücke erklärender Zusatz," see P. Prestel and S. Schorch "Genesis: Das erste Buch Mose," in Genesis bis Makkabäer, Vol. 1 of Septuaginta Deutsch: Erläuterungen und Kommentare zum griechischen Alten Testament (ed. M. Karrer and W. Kraus; Stuttgart: Deutsche Bibelgesellschaft, 2011), 145-257, here 242.

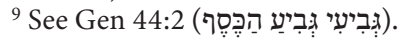


Joseph said to them, "What is this deed that you have done? Do you not know that a man

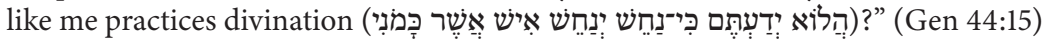

נחש, the term underlying the translation "to practise divination,"10 occurs in the Joseph story in these two passages only, and its use in combination with the

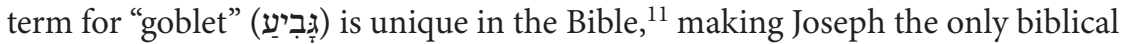
lecanomancer. The Masoretic Text does not explicitly say what form of lecanomancy is in view. Would it have been based on the patterns of liquid formed in a cup of oil, water, or wine? ${ }^{12}$ The Septuagint translates נַחש ינַח 44:5

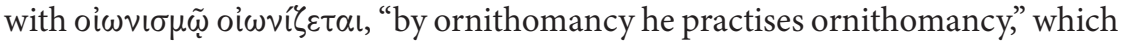
shifts the focus away from lecanomancy to ornithomancy, which in the Oxford English Dictionary is defined as "divination by means of the flight and cries of birds." Genesis 44:15 is similar. So, it appears that in the Joseph story, or at least in its textual tradition, the focus is more on Joseph practising some kind of divination per se rather than on a specific form of it. ${ }^{13}$ It is recounted matter-of-factly. The narrator does not seem to have had any scruples mentioning it, nor did he feel the need to condemn it. The same holds true for Laban, who is quoted as saying to his son-in-law Jacob, in Paddan-Aram, "I have learned by divination

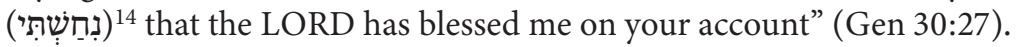

However, most of the other occurrences of the term נחש in the Hebrew Bible are used polemically. In Priestly or Deuteronomistic contexts, divination is strictly forbidden. In the Holiness Code (Lev 19:26) and in the Law Code of Deuteronomy (Deut 18:10) diviners are said to be "abhorrent to the LORD” (תועבת יהוה, Deut 18:12); divination is associated with the "abhorrent" practices of the nations (גוים) who lived in the promised land before the sons of Jacob took possession of it (Deut 18:9,12), so the Israelites are not to follow in their footsteps (Deut 18:14). In the second book of Kings, Israelites' practice of נחש is mentioned as one reason that provoked YHWH's anger and led to them being exiled to Babylon (2 Kgs 17:17-18). Also, Manasseh king of Judah practised נחש, making himself guilty of provoking YHWH to anger (2 Kgs 21:6; 2 Chr 33:6).

\footnotetext{
${ }^{10}$ So in DCH 5.667; HALOT 2.690 has "to seek and give omens, foretell".

${ }^{11}$ Note that the Hebrew word for "cup" or "goblet" mentioned in Gen 44:2-17 (גָּבְיעַ) is different from the word used in the passage about Pharaoh's dreams (סiּ, Gen 40:11-21) so there is no allusion between the two passages.

${ }^{12}$ See Ạ̣ıṭuv, "Divination” (see n. 6), 704.

${ }^{13}$ Not only in the Joseph story, but outside of it as well, נחש is "a broad term, simply signifying 'to divine' by unspecified means," see F. H. CRYER, Divination in Ancient Israel and Its Near Eastern Environment: A Socio-historical Investigation (JSOTSup 142; Sheffield: JSOT Press, 1994), 285.

${ }^{14}$ Naftali Herz Tur-Sinai translates this verb with "Ich hatte [vor deiner Ankunft] unter einem Zauberfluch gestanden", referring to Arabic narratives known in Palestine; similarely in Num 24:1, see N.H. Tur-SinAI, Die Heilige Schrift ins Deutsche übertragen (6th ed.; Witten: SCM Brockhaus, 2013), 1400.
} 
Strikingly, the practice of נחש is condemned when it refers to a practice within Judah or Israel. But when it refers to practices outside Judah or Israel - be it in Paddan-Aram (with Laban) or in Egypt (with Joseph) - the biblical authors display no qualms when mentioning divination. ${ }^{15}$

One might ask whether the narrator intends the picture of Joseph as lecanomancer to be taken at face value. The fact that Joseph's statement is part of a rhetorical question ${ }^{16}$ and plays no role in any other passage of the story ${ }^{17}$ could hint that Joseph's mentioning his divination practice is necessary only for the plot (as a means for Joseph to trick his brothers into bringing Benjamin back). Perhaps it does not reflect his habit. Furthermore, Joseph's sending for his brothers to tell them that they have stolen the cup which he uses for divination indicates that he found out about it without the cup. Joseph is thus portrayed in this passage as oscillating between practising deductive and inductive divination. ${ }^{18}$

While oracles were the primary form of divination practised in Egypt, ${ }^{19}$ there are indications that lecanomancy was practised there as well, but references to it are late, stemming from the Hellenistic period at the earliest. ${ }^{20}$ So within the Joseph story, with its time of the narration in the mid-second millennium BCE, a reference to lecanomancy in Egypt looks somewhat anachronistic. If the practice

${ }^{15}$ In the story of the non-Israelite seer Balaam we read that "there is no divination (נַחשׁ) in Jacob [...]; now Jacob [...] is told what God has done” (Num 23:23); cf. Num 24:1; 1 Kgs 20:33.

${ }^{16}$ In these phrases, introduced by הַלוֹא זֶה (Gen 44:5) הַוֹא ידַעִתֵם (Gen 44:15), a figura etymologica is used both times, which adds more weight to the statement. In none of the other occurrences in the Masoretic Text is a figura etymologica used with נחש or with the semantically comparable root ענן po. ("to interpret signs"); cf., however, the use of the verbal and nominal forms of קסם ("to predict”) in Deut 18:10; 2 Kgs 17:17; Ezek 13:23; 21:26.

${ }^{17}$ Contrast this with the notion of Joseph the dream-interpreter, which figures prominently in the Joseph story.

${ }^{18}$ A strong point for understanding Joseph's lecanomancy at face value is made by LANG, "Joseph the Diviner: Careers of a Biblical Hero" (see n. 7), who sees Joseph's role as a diviner to be one of a hero's tasks that "transcend the norm": the text implies that the newly created governmental position of Joseph may combine "the tasks of chief diviner and chief baker: research and policy making, theory and practice. The practical, grain-related task - storing grain and supervising its distribution - figures prominently in the story; by contrast, the theoretical task research based on mantic wisdom - remains undeveloped as the story continues, but is nevertheless hinted at," here 100.

${ }^{19}$ Documents concerning oracles are known from the New Kingdom and later, see J.M. Kruchten, "Oracles," in The Oxford Encyclopedia of Ancient Egypt, 2.609-612; CRYER, Divination in Ancient Israel (see n. 13), 217-223.

${ }^{20}$ See A. LAnge, "Becherorakel und Traumdeutung: Zu zwei Formen der Divination in der Josephsgeschichte," in Studies in the Book of Genesis: Literature, Redaction and History (ed. A. Wénin; BEThL 155; Leuven: University Press, 2001), 371-379, here 372; CrYer, Divination in Ancient Israel (see n. 13), 222 ("the only indications of this are, to the best of my knowledge, very late (Coptic)"). This makes it unlikely that Joseph, in the time of the narration (late mid-second millennium BCE), "had learnt the art of divination from the Egyptians", as David Davis argues in D. DAvis, "Divination in the Bible," JBQ 30/2 (2002), 121-126, here 124. 
of lecanomancy in Egypt is linked to the time of the narrator, it is safest to assume that he lived no earlier than in the late fourth century вСE.

\section{The Portrayal of Pharaoh}

In the Joseph story, the portrayal of Pharaoh and Egypt differs considerably from other parts of the Hebrew Bible. ${ }^{21}$ In the Exodus narrative, the Israelites were oppressed by one of the pharaohs who lived after Joseph's generation: he "did not know Joseph" and was afraid that the Israelites, who were becoming more and more numerous, may one day "fight against" them, and so he set out to kill all Hebrew baby boys (Exod 1:8-16, 22). Another pharaoh, whom Moses was to meet several times, "hardened" his heart (Exod 7:14; 8:11) and refused to let the Israelites go so that they may worship their god in the wilderness. This pharaoh's death in the sea is celebrated in the Song at the Sea (Exod 15:2, 21). In the Ten Commandments, Egypt is labelled "the house of slavery" (Exod 20:2). Similarly, in the books of Isaiah, Jeremiah and Ezekiel, prophetic oracles criticize Egypt (Isa 18; 19; Jer 42-44; 46; Ezek 29-32).

But in the Joseph story, Pharaoh is depicted in a uniquely positive way. $\mathrm{He}$ listens to the Hebrew prisoner Joseph (Gen 41:33-39); makes him second-incommand (41:40-44); gives him a wife of high standing (41:45); gives him authority (41:55); lets his extended family come to Egypt and stay there, allocating them in Goshen, the best part of Egypt (45:17-21; 47:5-6, 11); and finally, he lets Joseph and his family go back to Canaan to bury their father Jacob (50:4-8). ${ }^{22}$

Before Joseph met Pharaoh for the first time, "he shaved and changed his

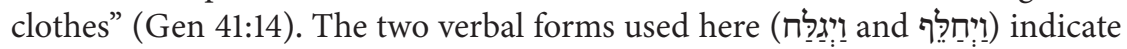
that this happened on Joseph's own initiative: he was careful to appear before Pharaoh in a way likely to find his favour. ${ }^{23}$ This is one of the details that show

\footnotetext{
${ }^{21}$ For an overview of the ambiguous image of Egypt in the Hebrew Bible, see B. U. SCHIPper, "Egypt, Ancient. II. Hebrew Bible/ Old Testament," EBR 7.497-499, here 498-499.

${ }^{22}$ This overall impression cannot be severly damaged by two references of Egyptians considering eating with Hebrews (Gen 43:32) or shepherds (46:34) an outright "abomination."

${ }^{23}$ Note that shaving is not associated with cleanliness or appropriateness: in graphic representations of the ancient Near East, male Semites are regularly displayed as bearded, Egyptians as clean shaven, see J. Berman, "Identity Politics and the Burial of Jacob (Genesis 50:1-14)," CBQ 68 (2006), 11-31, here 13-14; L. S. Fried, "Why Did Joseph Shave?", BAR 33 (2007), 36-41, rightly says that "[b]y shaving his beard, Joseph immediately transforms himself from a foreigner to an Egyptian. This change foreshadows Joseph's acceptance at court, as well as the fact that later Joseph's brothers will fail to recognize him, taking him for an Egyptian" (37). Fried also believes "that he shaved his entire body. In other words, I suggest that Joseph is depicted taking on the shaved body of the priesthood." (37) In the chronology of the narrated text, however, Joseph's family connection with a priest will be established only later (Gen 41:45). Furthermore, if being circumcised and shaved as well as abstaining from eating fish were requirements for entering the temple and the palace (41), it is striking that the third of these
} 
“the storyteller's positive evaluation of Joseph's full integration into Egyptian society." 24 Another relevant detail is Joseph's new name, to which I now turn.

\section{The renaming of individuals and its impact on their identity}

Gen 41:45 is one of only a few verses in the entire Joseph story where Egyptian individuals are named. ${ }^{25}$ Here we learn the name of Joseph's new wife, the name of her father, and the new name of Joseph - "Pharaoh then gave Joseph the name

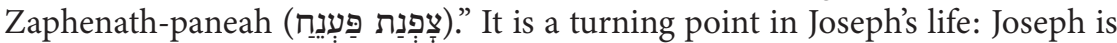
released from prison, interprets Pharaoh's dreams and, since Pharaoh sees that "nobody is as insightful and wise" as Joseph, Joseph becomes his second-in-command (Gen 41:39).

Surprisingly, Joseph's new name is never used again. Even after renaming Joseph, Pharaoh will say to all of Egypt, "Go to Joseph! Whatever he tells you to do, do it!" (Gen 41:55). In Pharaoh's house the name "Joseph" will be used (Gen 41:16), and when Pharaoh again meets Jacob's son, "Joseph" is the only name mentioned (Gen 45:17; 47:5). Pharaoh's new name for Joseph has no literary effect whatsoever on this character's designation.

Readers are left unsure about how they should interpret Joseph's new name. This contrasts the patriarchal history, where each name of the twelve sons of Jacob - including the name of Joseph - is translated or interpreted when their births are related (Gen 29:31-30:24). Obviously, the narrator did not deem it important to tell his Hebrew readers how he intended them to understand the (presumably) Egyptian phrase Zaphenath-paneah. Otherwise, the narrator would have provided this information. This is all the more striking in view of the fact that, only a few verses later, the meanings of the names of both of Joseph's sons are given when their births are narrated (Gen 41:51-52). ${ }^{26}$

To fill this lack of information, many have tried to explain what Joseph's new name means, both in antiquity ${ }^{27}$ and since the beginning of Egyptological studies

requirements is not said to be fulfilled in the Joseph story. So, the second requirement may be somewhat less probable as well.

${ }^{24}$ S. Niditch, "Why the Joseph Story Portrays Egypt Positively," in: TheTorah.com. A Historical and Contextual Approach, https://thetorah.com/why-the-josephstory-portrays-egyptpositively/. Accessed 01/25/21.

${ }^{25}$ We are not told the name of Potiphar's wife, of the chief baker and chief butler, of Joseph's steward or, most prominently, of the Pharaoh.

${ }^{26}$ The meaning of the name of Joseph's first-born son Manasseh is linked to the root נשה "to forget" and interpreted as "God has made me forget completely my hardship and my parental home," and the meaning of the name of Joseph's second son Ephraim is linked to the root be fruitful" and interpreted as "God has made me fertile in the land of my affliction" (Gen 41:52).

${ }^{27}$ Interestingly, Josephus seems to link the meaning of Joseph's new name to his role as a

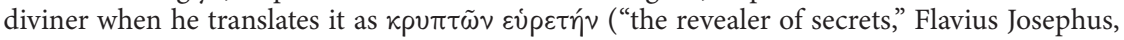
Ant. 2.6.1 $\$ 91)$. 
in the nineteenth century. The Egyptologist Georg Steindorff was among the first to understand the name as deriving from the artificial form $D d-p^{3}-n t r-$ $i w . f-n h$, which can be translated as "The God speaks: 'May he (the child) live!'” This interpretation is generally still followed today, ${ }^{28}$ although in the Egyptian onomasticon, this name type always contains a nomen dei, which is not the case here: $p^{3}-n t r$ is the article followed by a common noun, the equivalent of the Hebrew häèl ("the god"). Also, such an Egyptian form would have been used as a birth name, but in the Joseph story, the new name is given to a thirty-year-old (Gen 41:46). Still, the phrase used with this name (Gen 41:45) is the one used most frequently when newborns are named. ${ }^{29}$

Some other individuals in the Bible receive a new name from the king of a foreign nation. Towards the end of 2 Kings, we read that Pharaoh Neco made Eliakim the king of Judah. When doing so, he gave him the name Jehoiakim (2 Kgs 23:34; $2 \mathrm{Chr} \mathrm{36:4).} \mathrm{One} \mathrm{chapter} \mathrm{later,} \mathrm{we} \mathrm{read} \mathrm{that,} \mathrm{shortly} \mathrm{before} \mathrm{the}$ fall of Jerusalem in 587 все, Nebuchadnezzar king of Babylon gave Judah's last king Mattaniah the name Zedekiah (2 Kgs 24:17). ${ }^{30}$ Contrary to Joseph in the Joseph story, both Jehoiakim and Zedekiah are only mentioned again by these new names, not their birth names. ${ }^{31}$ With the first king, the change from Eliakim to Jehoiakim means that the generic word for "god" was replaced with the short form of the tetragrammaton. With the second king, both his old name (Mattaniah) and his new name (Zedekiah) include a short form of the tetragrammaton. ${ }^{32}$ Surprisingly, both of these foreign rulers are said to have endowed the two Judeans with a name in Hebrew rather than in Egyptian or in Babylonian. Moreover, the new names contain an Israelite theophoric element. The texts say nothing about how these Hebrew names were chosen.

${ }^{28}$ For details, see B. U. SChipper, "The History of Egyptology and the Gesenius Dictionary," in Biblische Exegese und hebräische Lexikographie (ed. S. Schorch and E.-J. Waschke; BZAW 427; Berlin: Walter de Gruyter, 2013), 484-507, here 499-500.

${ }^{29}$ With שישם and "to call (someone by) a name," see, e.g., the phrasings of the namings at birth to Seth (Gen 4:25), Moab (19:37), Ben-ammi (19:38), Reuben (29:32), Simeon (29:33), Levi (29:34), Judah (29:35), Dan (30:6), Naphtali (30:8), Gad (30:11), Asher (30:13), Issachar (30:18), Zebulun (30:20), Dinah (30:21), Joseph (30:24), Ben-oni (35:18), Onan (38:4), Shelah (38:5), Samson (Judg 13:24), Samuel (1 Sam 1:20), Peresh (1 Chr 7:16).

${ }^{30}$ Note the phrasing used here: סבב with שֵ "to change (someone's) name (to)," and compare with the previous note.

${ }^{31}$ In the parallel accounts in the books of Chronicles, only the renaming of Eliakim is told (2Chr 36:4-8, 10-13) but not the one by Mattaniah.

32 Jehoiakim (Yěhôyāqîm, literally "Yah established") is a verbal sentence name with the theophoric element Yah at the beginning; other examples of this name type include Jehoshaphat, Joahaz, Joash, Johanan, Joiada, Jonathan, Joram, Jotham. Zedekiah (Șidqiyyāh [ûu, literally "Yah is righteousness") is a nominal sentence name with the theophoric element Yah at the end; other examples of this name type include Abijah, Adonijah, Ahijah, Elijah, Hilkiah, Uriah, Uzziah. See H. Rechenmacher, Althebräische Personennamen (Lehrbücher orientalischer Sprachen Textbooks of Near Eastern Languages 2/1; Münster: Ugarit-Verlag, 2012). 
Hence, whereas in the book of Kings Pharaoh Neco gives the Judean king a name with the theophoric name Yah, which suggests an Egyptian king knows the name of the God of Israel, in the Joseph story Pharaoh acts differently. When renaming Joseph, he uses or creates an Egyptian name with a generic word for a deity, handling the renaming sensitively by not naming a Hebrew individual with an Egyptian nomen dei. ${ }^{33}$ This fits with the overall tendency in the Joseph story to avoid the tetragrammaton when referring to god. Note, for example, the deliberate use of "élohîm, which can mean both "god" and "gods", in the conversation between Pharaoh and Joseph in Genesis 41: Joseph can be understood to be referring to YHWH (Gen 41:16, 25, 28, 32) while the same common noun used by Pharaoh may translate to any Egyptian deity or deities $(41: 38,39){ }^{34}$

On one more occasion we read of a name change effected by a royal or at a royal court. At Nebuchadnezzar's palace in Babylon, the names of the four Judeans Daniel, Hananiah, Mishael and Azariah (Dan 1:3-6) are all Hebrew, and each name contains either El or Yah. The king's chief officer eventually gives them new names: Belteshazzar, Shadrach, Meshach, and Abednego (Dan 1:7). ${ }^{35}$ None of these new names are Hebrew, and two of them (Belteshazzar and Abednego) contain the name of a Babylonian god. ${ }^{36}$ After Dan 1:7, the new names of Daniel's three friends occur mainly in ch. $3,{ }^{37}$ while their old names are mentioned again in ch. 1 and $2 .{ }^{38}$ Like in the Joseph story, the new name given to

\footnotetext{
${ }^{33}$ Note that this applies only to Zaphenath-paneah, the new name of Joseph. The names of the few other named Egyptian individuals in the Joseph story do contain the name of an Egyptian deity: Neith is part of the name Asenath, and Ra is part of Potiphera (Gen 41:45, 50; 46:20) and Potiphar (37:36; 39:1). See Schipper, "The History of Egyptology and the Gesenius Dictionary" (see n. 28), 498-499, and R. Meyer and H. Donner (eds), Wilhelm Gesenius: Hebräisches und Aramäisches Handwörterbuch über das Alte Testament (18th ed.; Heidelberg: Springer, 1987-2012), 83.1042-1043.

${ }^{34}$ Within Genesis 37-50, 'élohîm is used thirty-five times in all (in Genesis 39-46; 48; 50), whereas the tetragrammaton is used only in three chapters, and most often in Genesis 39 (eight times: v. 2-3, 5, 21, 23; the other occurrences are in Gen 38:7, 10 and in 49:18).

${ }^{35}$ Note the phrasing used here: שים with שים "to put a name (on)", and compare with note 29 above.

${ }^{36}$ The name Belteshazzar is Akkadian in origin, and according to its vocalisation it can be translated with "May Bel protect the life of the king"; so, the name is referring to Marduk, whose son's name Nabu is also part of the name Nebukadnezzar (cf. also Isa 46:1; Jer 50:2). The form of the Aramaic name Abednego is probably related to Nabu as well. The origin of the name Shadrach is Akkadian or Iranian, and the form Meshach may be Persian in origin or it may be corrupt. See MeYer and Donner, Hebräisches und Aramäisches Handwörterbuch (see n. 33), 152.771.911.1326.669.

${ }^{37}$ See Dan 2:49 and Dan 3:12-30* (the story of the fiery furnace). Some conclude that this tale was secondarily added to the book of Daniel: see, e.g., D. BAUer, Das Buch Daniel (NSK. AT 22; Stuttgart: Verlag Katholisches Bibelwerk, 1996), 74.

${ }^{38}$ See Dan 1:11, 19; 2:17. As the story unfolds, most of the times that Daniel is mentioned (Dan 2:26; 4:5, 6, 15, 16; 5:12; 10:1) he is identified with Belteshazzar. Apparently, it was found necessary to remind the reader that Daniel and Belteshazzar are identical persons (Daniel/ Belteshazzar is not mentioned in the story of the fiery furnace in Dan 3).
} 
the Hebrew individual(s) is in a language other than Hebrew, but unlike in the Joseph story, some of the new names have a theophoric element by mentioning the name of a local deity.

\section{Conclusion}

Comparing some aspects of the Joseph story with how the same issues are dealt with elsewhere in the Hebrew Bible, we can detect a certain flexibility in approaching questions of identity. In a religious environment without Hebrew prophets or a temple of $\mathrm{YHWH}$, divination is used as a way of channelling revelation. ${ }^{39}$ Relationships, both among individuals and among larger units, show tight boundaries in some contexts (e.g. Ezra-Nehemiah in Babylon) but porous ones in Egypt (Joseph). By living in Goshen, a secluded part within Egypt, the Jacob family has the possibility to maintain an identity away from their homeland. Still, Joseph married an Egyptian woman, demonstrating that there is not just a single option for building Jewish identity.

This reminds readers that various texts of the Hebrew Bible show a certain openness in their approach to these issues. Simplistic models of linear developments of biblical theology (e.g., from strict to liberal) are unreliable; rather, differing contexts call for different solutions. Jewish identity in the post-exilic period was complex; the position of some communities, such as the one behind the Joseph story, was apparently quite "open."

\footnotetext{
${ }^{39}$ Remember that no biblical texts were found among the texts from the Archives in Elephantine.

${ }^{40}$ See T. Römer, The So-Called Deuteronomistic History: A Sociological, Historical and Literary Introduction (London and New York: T\&T Clark), 2007, 177 n. 29: "If the Joseph story was originally composed in the Egyptian Diaspora, as it would now be argued by several scholars, it shows that the Jews living in Egypt had a much more open position." See also LANG, "Joseph the Diviner. Careers of a Biblical Hero" (see n. 7): "Diaspora Jews form an open rather than a closed society, and in this they differ from those committed to a Judaism based upon the principle of separation and strict adherence to the law of Moses," here 103.
} 


\title{
Forced Migration and Reconciliation in the Joseph Narrative
}

\author{
Safwat Marzouk
}

Considering the function of the Joseph narrative as a bridge between the ancestral stories and the exodus to be secondary, ${ }^{1}$ scholars made different proposals that seek to explain the purpose of the composition of the independent Joseph narrative prior to its integration with other Pentateuchal traditions. ${ }^{2}$ For instance, the story of Joseph is treated by some scholars as a diaspora novella, because its main character rises to power in a foreign court, and because the story reflects and addresses the needs of those who were forced to live away from Israel and Judah. ${ }^{3}$ Because the story is not just about Joseph's rise to power in a foreign

\footnotetext{
${ }^{1}$ Given the difficulty of tracing the Pentateuchal sources J and E in the Joseph narrative and given that the doublets can be explained as a literary style of the novella, some scholars have questioned the role of this unified story as a bridge between the ancestral narratives and the Exodus story. For a fuller discussion see D. B. ReDFord, A Study of the Biblical Story of Joseph (Genesis 37-50) (VTSup 20; Leiden: Brill, 1970), 244-253; C. Westermann, Genesis 37-50: A Commentary (trans. J.J. Scullion s.j.; Minneapolis, MN: Augsburg Publishing House, 1986), 1530; K. Schмid, "Die Josephsgeschichte im Pentateuch", in Abschied vom Jahwisten: Die Komposition des Hexateuch in der Jüngsten Diskussion (ed. J.C. Gertz et al.; BZAW 315; Berlin: Walter de Gruyter, 2002), 83-118; M. C. Genung, The Composition of Genesis 37 (FAT 95; Tübingen: Mohr Siebeck, 2017), 204-216. I follow the view that Joseph's descent into Egypt and the descent of the brothers into Egypt are part of the original independent Joseph story. In this I differ from Franziska Ede who distinguishes between Joseph's migration to Egypt and the brothers' descent to Egypt as two different layers of the composition of the story. F. EDE, Die Josefsgeschichte: Literarkritische und redaktionsgeschichtliche Untersuchungen zur Entstehung von Gen 37-50 (BZAW 485; Berlin: Walter de Gruyter, 2016), 513-523.

${ }^{2}$ K. Schmid, The Old Testament: A Literary History (trans. L. M. Maloney; Minneapolis, MN: Fortress Press, 2012), 120-122.

${ }^{3}$ Recent Scholarship on the narrative of Joseph, which is embedded along with other texts in Genesis 37-50, has focused on reading the novella as a diaspora story. That is, the story reflects and addresses the needs of individuals or communities that do not live in their homeland. Thomas Römer notes "It is easiest to explain the attention given to describing the Egyptian integration and career of Joseph if one assumes that the Joseph story is a 'diaspora novella' and was conceived in order to reflect the possibilities for a life outside the land," see T. RöMER, "The Joseph Story in the Book of Genesis: Pre-P or Post-P?," in The Post-Priestly Pentateuch: New Perspectives on Its Redactional Development and Theological Profiles, (ed. F. Giuntoli and K. Schmid; FAT 101; Tübingen: Mohr Siebeck, 2015), 185-201, here 192. In his article "Reading the Joseph Story (Genesis 37-50) as a Diaspora Narrative" Hyun Chul Paul Kim states, "in the story of the Diaspora communities, Joseph portrays a model life amid the sociopolitical, ethnic, and economic struggles and tensions between the "insiders" and the "outsiders," and between
} 
court, but it also describes Joseph's conflict and reconciliation with his brothers, it has been suggested that the Joseph novella deals with the issue of reconciliation between the members of a fractured Israelite community. ${ }^{4}$ The theme of reconciliation between Joseph and his brothers, prominent among whom is Judah, parallels the vision of reconciliation between "Judah" and "Joseph/ Ephraim" put forth by the exilic prophet Ezekiel (37:19). Unlike Ezekiel, however, who envisioned the reconciliation to take place on the mountains of Israel, the Joseph narrative suggests that reconciliation can take place in the diaspora. That reconciliation happens in a foreign land calls for reflection on the role that forced migration could play in transforming the different agents who are involved in a given conflict.

In this article, I suggest that the geographical movement of Joseph's brothers between Canaan and Egypt, which resulted from an existential crisis, namely, the famine, parallels and effects the transformation of their moral character which was marked by hatred and apathy into a character that is motivated by solidarity and empathy. Joseph's brothers were transformed by way of walking a journey that is similar to Joseph's journey of estrangement; their migration to Egypt allowed them to experience what it means to be at the power of an other, and to be treated as foreigners.

Their transformation is evident in the way they expressed sympathy towards their father and in refusing to reproduce the same violence they did to Joseph against their youngest brother, Benjamin. On the surface, as an Egyptian ruler, Joseph's treatment of his brothers as foreigners seems like a tit-for-tat kind of justice; deep down under the surface, Joseph's alienation of his brothers can be thought of as a journey towards empathy and transformation. Unlike the brothers who were in need of experiencing a calculated alienation so that they would be transformed and therefore be ready to reconcile with their brother, Joseph - who had named one of his sons Manasseh, which means "because God made me forget my suffering and my father's house," thus distancing himself from his family - needed to see the hardships of his migration and his rise to power in relation to the survival of his family. Joseph's transformation meant coming to terms with his dreams about power; when he had forgiven his brothers, Joseph

the powerful and the marginalized," see H.C. P. KIM, "Reading the Joseph Story (Genesis 37-50) as a Diaspora Narrative," CBQ 75/2 (2013), 219-238, here 220.

${ }^{4}$ Joseph's relation to his brothers occupies a major part of the story that some scholars suggest we call the story "Joseph and his Family" or "Joseph and his Brothers." The conflict between Joseph and his brothers and its resolution forms the plot of the narrative according to W.L. Humphreys, Joseph and His Family: A Literary Study (Columbia, SC: University of South Carolina, 1988), 32-67; R. J. Clifford, "Genesis 37-50: Joseph Story or Jacob Story," in The Book of Genesis: Composition, Reception, and Interpretation (ed. C.A. Evans et al.; VTSup 152; Leiden: Brill, 2012), 213-229. Clifford's analyses seek to recover the theme of "the powerful rivalry between the brothers for firstborn status", here 214 . 
showed that his power is not over or against his brothers but for the sake of his family. ${ }^{5}$

In order to explain the relation between migration and reconciliation in the story of Joseph, I will offer a close reading of specific scenes of Joseph's interaction with his brothers in Gen 42-44. Then I will discuss Joseph's response to Judah's long speech as we find it in Gen 45:1-15.

\section{Joseph's Estrangement from his Brothers}

Gen 42 shifts the scene from Pharaoh's court and from Joseph's integration into the Egyptian society to Canaan, where the famine was severe and there was no food for Joseph's family. When Jacob saw that there was food in Egypt, he told his children:" Why are you looking at each other?" It is unclear what the phrase "looking at each other" indicates. Does it indicate being desperate in light of the severe famine? Or are they, through these looks, blaming the famine on each other, which for them might have been seen as a divine punishment for their evil act against Joseph? Why are the brothers delaying the inevitable step of going down to Egypt, which is dramatically highlighted by the author who repeats the pronoun שם "there" twice in v. 2? Were the brothers afraid that they might encounter Joseph who was sold into Egypt? Or are they trying to avoid going down to a country where "the detested monarchy (Gen 37) is all-pervading"? ${ }^{6}$ At any rate, Jacob realizes that for his family to survive and avoid death, they need to go down to Egypt. It is a matter of life and death. As the brothers get ready to go down to Egypt, Jacob refuses to send Benjamin with them for he thought a "harm might come to him." Benjamin now has taken Joseph's place in being his father's favorite. Favoritism here recalls Jacob's treatment of Joseph (Gen 37) and sets the narrative in a place that makes the reader wonder how the brothers will respond to Jacob's renewed partiality.

The presence of the brothers in Joseph's court in Egypt causes the geographical distance between Canaan and Egypt to collapse, and the temporal gap between the past and the present to narrow as the brothers bow down before Joseph reminding him of his own dreams. Taken by surprise by the fact that his dreams are finally being fulfilled and that his brothers who have alienated him are right before his eyes, Joseph probably was not sure what to do: should he take revenge? Should he reconcile with his brothers? Joseph decided to start with what he is

\footnotetext{
${ }^{5}$ I do not mean to imply that Joseph was dreaming of power; but his dreams, which are complicated in terms of their structure, content and meaning, are certainly about the issue of power. On the complexity of Genesis 37:1-11 and the scholarly proposals to solve the problems of its composition, see Genung, The Composition of Genesis 37 (see n. 1), 89-168; See also the discussion in EDE, Die Josefsgeschichte (see n. 1), 3-27.

${ }^{6}$ Westermann, Genesis 37-50 (see n. 1), 105.
} 
familiar with the most, being treated as a foreigner. The text notes that: When

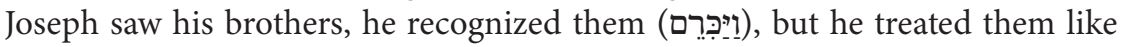

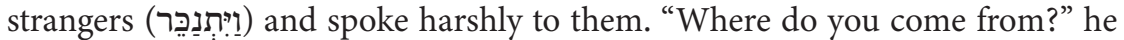
said. They said, "From the land of Canaan, to buy food." Although Joseph had

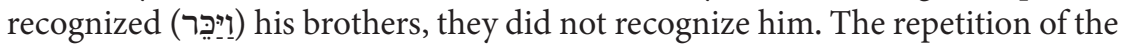
Hebrew root (נכר) "to recognize" "to disguise" or "to treat as a foreigner" underlines the importance of the theme of foreignness as the text unpacks the relationship between Joseph and his brothers. Have Joseph's features changed so much over the past twenty-two years that his brothers were unable to recognize him? Or is it the Egyptian dress, language, and power that made him unrecognizable to them? That Joseph treats his brothers as foreigners and that the brothers do not recognize him recalls the words they said to their father in Gen 37:32. After the brothers had dipped Joseph's robe in blood, they asked their father to "recognize" (נכר), to find out, whether this is Joseph's robe, and Jacob did recognize it as such. Although they knew that it was Joseph's robe, they pretended not to know whose robe it was. Now it is Joseph who acts as if he does not know who they are, although he recognizes them. If Joseph's intention was revenge, one wonders why he would not simply come out to his brothers with his true identity and use his power to pay back their violence against him. On the surface, treating them as foreigners is in some way a payback for the way they sold him into slavery; but on a deeper level, it is possible that this process of estrangement holds more fruit for the relationship between Joseph and the brothers beyond a tit-for-tat kind of justice. ${ }^{7}$

The process of estrangement and alienation of the brothers by Joseph intensifies as Joseph speaks harshly to them accusing them of being spies. They are not just foreigners; they are harmful, deceitful, and dangerous foreigners. Now the brothers experience the injustice that Joseph endured when he was treated as a malicious foreigner, who was thrown into prison for being accused of rape. He accused them of being harmful foreigners who have come to see the nakedness of the land, and then he imprisoned them $(42: 16,19,24)$. Claiming that he fears God, Joseph decided to release them and put their honesty to the test, if they

\footnotetext{
${ }^{7}$ Meir Sternberg reflects on the role Joseph plays in the development of the narrative, when he writes "Throughout the drama of retrospection, Joseph figures as stage-manager as well as player, exploiting his superiority to assign roles to his brothers along two lines. One consists in role-reversal, whereby he gives them a taste of his own suffering - helplessness in the hands of a bully, false charge with death in the offing, imprisonment, abrupt commutation of sentence - by forcing them to go through it in experiential order. Whether motivated in punitive or redemptive terms, this is what his policy has seemed to amount to. With the slipping of the money into the bags, however, there emerges another line of stage management: role- $d u-$ plication, whereby he compels them to relive not his past but their own, reproducing something like the old temptations to find out whether they will now make the same criminal choice," see M. Sternberg, The Poetics of Biblical Narrative: Ideological Literatures and the Drama of Reading (Bloomington, IN: Indiana University Press, 1987), 294.
} 
want to live and not die, echoing Jacob's words at the beginning of the chapter, they must bring their youngest brother down so that he would see him, but in the meantime, he will keep Simeon as a prisoner $(42: 2,18,20){ }^{8}$

The farther Joseph positions them away from himself by treating them as mischievous foreigners, the closer they are drawn to him, as they walk the journey of alienation that he had experienced. When he treated them as foreigners, called them spies, casted doubt on their honesty, imprisoned them, kept one of them a bargain chip, put them in a situation where they have to ask their father the impossible, namely, bringing Benjamin down to Egypt, Joseph put his brothers in a place where they can connect their plight with Joseph's plight. "They said to one another, 'Alas, we are paying the penalty for what we did to our brother; we saw his anguish when he pleaded with us, but we would not listen. That is why this anguish has come upon us" (42:21).

Confessing their guilt, the brothers see their experience in Egypt in light of what they had done to Joseph. This is evident in using the same word (צרר) to describe their and Joseph's plight. Their confession takes the reader into Joseph's emotional state, which the narrator did not previously expose. When Joseph was thrown into the pit and when he was forced to migrate, what deepened the wound in his soul was that his own brothers, who looked deeply into his pain, refused to listen to his outcry for mercy. No wonder the narrative repeatedly reports Joseph's emotional breakdowns every time he encountered his brothers $(42: 24 ; 43: 30 ; 45: 1-2)$. The brothers did not just refuse to listen to Joseph's cries, they also refused to heed Reuben's advice; and now his blood is sought out. The

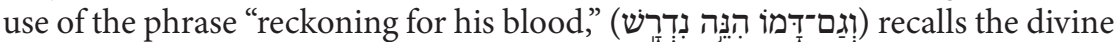
covenant with Noah, which entailed that God would reckon for the blood or life

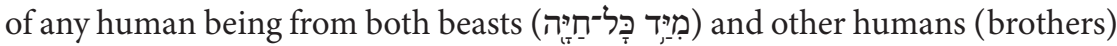

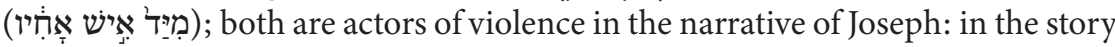
that the brothers fabricated to their father and in the real story of their violence against Joseph.

The presence of an interpreter between Joseph and his brothers simultaneously underlines the foreignness of the brothers and Joseph's ability to move between two cultures and two roles: he is a brother who has an insider view on who the brothers really are, he understands the words in which they expressed their vulnerability, yet he is also the harsh ruler who controls their destiny. The presence of an interpreter also shows that the dialogue between Joseph and the

\footnotetext{
${ }^{8}$ Although Simeon's imprisonment is treated as secondary by some scholars, I think it is integral to the narrative. Simeon's imprisonment guarantees that the brothers would return. His absence from the discussion between Jacob and Reuben and Judah can be explained by the fact that Benjamin overshadows the concern for non-Rachel children. Note also that Reuben volunteers his children before the food runs out, because Simeon is in Egypt. Sternberg explains: "as Leah's second son, Simeon makes the perfect hostage for Benjamin, Rachel's second." STERNBERG, The Poetics of Biblical Narrative (see n. 7), 291.
} 
brothers requires further interpretation beyond the immediate reference of their words. Clearly, Joseph knows that they are not spies. It is not clear whether Joseph had all of his plan figured out at this stage, yet it seems that he is trying to figure out if they have changed or not. Did they really mean the words of their confession? Will they act in a similar way if they were to be positioned in the same situation? Here comes the ulterior meaning of his request for Benjamin. Will the brothers treat Benjamin the same way they have treated Joseph? As Joseph continues to test his brothers, he himself is also being tested: will he embrace them as family, allowing his relationship with them to give new meaning to his forced migration and rise to power?

Putting the money back in the sacks of his brothers is an ambiguous act that leaves the brothers in a liminal space of perplexity and confusion. Is this a form of generosity, like providing provisions for the road? Or is Joseph trying to intensify their fear? The reference to the money reminds the reader of the money that the brothers received when they had sold Joseph to the Ishmaelites. Indeed, "silver" or "money" is mentioned 20 times in Gen $42-45$ in relation to Joseph's brothers, which is the exact number of the money they received for selling Joseph. Thus, the reference to the money connects Joseph's descent into Egypt and the brothers' movement between Canaan and Egypt. We might not know Joseph's motive for returning the money, but we know how the brothers felt about it. When one of them discovered the silver, they lost heart and turned trembling to one another, saying, "What is this that God has done to us?" Later we know that "they and their father were afraid" (42:35). While Joseph and the reader know who is behind this, the brothers are trying to understand their situation theologically wondering if this is a divine punishment. Their question about God's intention and their lack of knowledge of Joseph's agency show that the Joseph novella presents a complex understanding of divine sovereignty and human responsibility, an issue that we will revisit in Joseph's speech.

Their fear that resulted from finding their money in their sacks is just the tip of the iceberg of the vulnerable situation that they found themselves in. Now they are entangled between Egypt and Canaan: they have a brother who is imprisoned in Egypt, they have to convince their father to send Benjamin with them if they were to go down to Egypt again to buy grain, and they have to give an account for the missing money. Nothing expresses the difficulty of this situation better than the words of Jacob who blames the brothers for bereaving him of his children: Joseph, Simeon, and now Benjamin. He then goes on to assert that Benjamin will not go down with them to Egypt. Benjamin's brother is dead, he alone is left out of Rachel's children. "If harm should come to him on the journey that you are to make, you would bring down my gray hairs with sorrow to Sheol." Jacob's concern about Benjamin forms an inclusio that appears at the beginning and end of Gen 42; more importantly, it connects the request for Benjamin to go down to Egypt with Joseph's descent to Egypt and it anticipates Judah's words to 
Joseph when he is in Egypt. Although Jacob connects the descent of Joseph and Benjamin to Egypt with his own descent to Sheol - thus a trip to Egypt is marked by loss and death - he will be proven wrong as the narrative unfolds.

Knowing that the only way to survive the famine is to go back to Egypt, Jacob and his children had to make difficult decisions. While Jacob must take the risk of sending Benjamin with his brothers, thus taming his favoritism for the sake of the family, Jacob's children must engage Benjamin's special place in the family away from the politics of hatred and jealousy which they have pursued in relation to Joseph. Being caught between life and death, between Canaan and Egypt, the moral character of the brothers was given another chance to transfer from apathy to empathy. Responding to Jacob's loss of his children, Reuben vows to bring Benjamin back to his father; if he does not then Jacob has the right to kill Reuben's two sons. This hyperbolic vow means that Reuben will do anything to bring Benjamin back and that Reuben now understands what it means for a father to lose a child. Judah, then, goes on to join Reuben's vow to his father about the safety of Benjamin. Judah will bear the guilt before his father all the days if he fails to bring Benjamin back. Not only does Judah move away from selfishness, which was evident in selling Joseph, to show concern over the well-being of the whole family, he also gets closer to confessing his guilt towards his father for depriving him of one his sons already. Despite their closeness in geographical distance to their father, it is their movement back and forth between Egypt and Canaan that is making Reuben and Judah identify with their father's pain. Eve Jacob, though reluctant and under the pressure of this existentialist situation, became malleable and agreed to send Benjamin with his brothers down to Egypt. As he prayed that God the Almighty would grant them mercy (רחם) before the man, he anticipated the compassion (רחם) that will overtake Joseph when he sees Benjamin. That the brothers are going to Egypt with Benjamin, the second Joseph, carrying with them "a little balm and a little honey, gum, resin, pistachio nuts, and almonds" $(43: 11,15)$ echoes the descent of the Ishmaelites to Egypt who had Joseph with them and who were going down there to sell "gum, balm, and resin" $(37: 25 ; 39: 1)$. Cast in this way the brothers' complex identity both as family and as outsiders is exposed. Will they abandon Benjamin as they have abandoned Joseph? Or will they change the course of the caravan of apathy to the destination of empathy?

Carrying these gifts leads to the next episode in which Joseph hosts the brothers in his house for lunch. The details of the narrative continue to bring the brothers closer and closer to the real test, namely, Benjamin's safe return to Jacob in Canaan. The details of this scene recall various details from the episode of selling Joseph himself: the notion of seeking shalom (37:14; 43:27-28), showing graciousness or denying it (42:21; 43:29). Furthermore, the brother's meal in Joseph's house parallels the meal that the brothers ate in the field while their brother was in the pit $(37: 24-25 ; 43: 33)$. Not only does the meal underline the separation between the Egyptians and the Hebrews, thus positioning Joseph 
in a liminal space between the Egyptians and the Hebrews, it also highlights the change in power relations between Joseph and his brothers in this episode compared to what happened in Gen 37.9 Unlike the brothers who ate while Joseph was thrown into the pit, Joseph showed generosity towards his brothers by giving them portions from his own table. ${ }^{10}$ Yet when he gave portions to Benjamin five times more than the rest of the brothers, he reenacts Jacob's favoritism. Thus, this episode continues to put the brothers in the same situation that they have mismanaged with Joseph. Benjamin's descent into Egypt, as the second Joseph, offers a second chance for the brothers to embrace their younger brother rather than alienate him.

The tension around Benjamin heightens as the Egyptian master plots yet another test. The brothers who tried to put an end to Joseph's dreams are now accused of stealing the Egyptian master's silver cup which he uses for divination. When Joseph's servant seized them outside the city he said to them "Why have you returned evil for good?" Meeting good with evil anticipates Joseph's words to his brothers in Gen 50:20 "Even though you intended to do harm to me, God intended it for good." Thus, the words that the servant uttered on Joseph's behalf bind together the brother's betrayal of Joseph in Canaan and the brother's theft of the cup of the Egyptian master in Egypt. Confident in their honesty the brothers deny that they have stolen anything from the Egyptian master's house, especially given that they have returned the money that was found in their sacks. Therefore, they announce to Joseph's servant "Should it be found with any one of your servants, let him die; moreover, the rest of us will become my lord's slaves." Again, the brothers intend well, but they do not know as much as Joseph does. Searching

\footnotetext{
${ }^{9}$ Katie M. Heffelfinger offers a close study of the role that meals play in the Joseph narrative as an expression of power. She writes, "in the narrative of Jacob's sons food language signals the presence of material relevant to the plot's power dynamics. These dynamics are heavily impacted by favoritism, both human and divine. When seen as part of this larger symbolic thread, the meal around the pit (37.35) and the meal in Joseph's house (43.26-34) are not just incidental events in the narrative. Rather, they together set the conditions for the event of reconciliation. Reconciliation must occur away from the table because a rivalrous response to Joseph's special status, symbolized by food in the narrative, must be rejected before reconciliation can occur." K.M. Heffelfinger, "From Bane to Blessing: The Food Leitmotif in Genesis 37-50*" JSOT $40 / 3$ (2016), 297-320, esp. 299. I agree that the meals play a significant role in the narrative, yet reconciliation happens when the brothers, represented by Judah, accept Joseph's and Benjamin's status (as I will show below in this chapter). Furthermore, in the context of the full narrative, the motif of food does not fade away, and Joseph does not lose his power, but rather he uses it in order to provide food for his family $(47: 12 ; 50: 21)$.

${ }^{10}$ Peter Altmann suggests that feast in Joseph's house "focuses far more on the issue of the reconciliation of Joseph with his brothers and the maintenance of his role. The narrative depicts Joseph as using the feast to solidify his role as patron over his brothers. Similarly, his 'gift' of the cup in Gen 44 embodies symbolic favor for his full brother Benjamin in a way that he, as the patron, expects his clients - the ten brothers - to embrace." P. Altmann, "Feasting like Royalty in a Time of Famine: Reflections on the Meaning and Composition of the Feast in Gen 43:1534," ZAW 130/3 (2018), 349-363, esp. 361-362.
} 
in their sacks from the oldest to the youngest not only recalls the order in which they sat before Joseph when they ate in his house, it also zooms in and intensifies their anxiety as the man approaches the sack of their youngest, Benjamin. When the man had found the cup in Benjamin's sack, they tore their garments; in this way, they identified with Jacob who tore his garment when he heard of Joseph's death, not to mention that losing a garment and putting on a new one has also occurred in Joseph's experience of migration $(37: 23 ; 37: 33 ; 39: 12 ; 41: 42 ; 45: 22){ }^{11}$

What they had feared has happened. Benjamin's destiny, Jacob's well-being, and their integrity now hinge on how the Egyptian master will treat them. Upon seeing Joseph in his house, they fell down to the ground. Joseph continues to emphasize his foreignness. They do not know his true identity, but he expects them to know that he is different from them religiously; he practices divination, a practice that the legal material of the Pentateuch prohibits (Lev 19:26; Deut 18:10; 2 Kings 17:17). Out of words, full of fear, Judah exclaims "how can we clear ourselves?" He goes on to confess "God has found out the guilt of your servants." While Judah is referring to guilt for a crime that they did not commit, the irony is that his words refer to their guilt of forcing Joseph to migrate. When Joseph announced that he would make a slave the man with whom the cup was found, Judah drew near asking the Egyptian master not to get angry and he asked to say a word, which turns out to be one of the longest speeches in the book of Genesis.

For our discussion three aspects about Judah's speech are important to highlight: 1. He acknowledges Joseph's power. While Judah compares Joseph's power and status to that of Pharaoh, by repeating the word עבד twelve times, he compares his, his father's, and the rest of his brothers' status to that of Joseph's servants. 2. Judah's speech contains an acceptance of the special relationship Jacob has with Rachel's children. 3. Judah expresses his willingness to take the place of his brother, Benjamin, the second Joseph, so that he would follow through with his vow to his father and so that he would save his father's life. Judah who initially saw no benefit in killing his brother, Joseph, so he decided to sell him into slavery, is now willing to become a slave himself so that he would save his brother and his father from slavery and death, respectively. ${ }^{12}$ Judah's willingness to take Benjamin's place underlines the transformation that happened to the moral

${ }^{11}$ Scholars have noticed the function of the garment motif as an indicator of status in the Joseph narrative. See V.H. MatThews, "The Anthropology of Clothing in the Joseph Narrative," JSOT 65 (1995), 25-36; and J.R. Huddelston, "Divestiture, Deception, and Demotion: The Garment Motif in Genesis 37-39," JSOT 26/4 (2002), 47-62.

${ }^{12}$ Ron Pirson seems be hesitant to speak of a transformation of the brothers. And it is unclear whether he seeks to differentiate between the brothers and Judah, or whether he is dismissing the genuineness of Judah's transformation. For example, he writes: "it is hardly legitimate to say 
character of the brothers. ${ }^{13}$ Their acknowledgment of their guilt towards Joseph, which they uttered in 42:21 takes a concrete form when they refuse to do the same cruelty that they had done to Joseph to Benjamin. While Judah's primary concern here is the well-being of Jacob, Joseph in Gen 50 assures them that his forgiveness is not dependent only on the life of Jacob. ${ }^{14}$

Judah's willingness to take Benjamin's place shows that the current situation is not a straightforward tit-for-tat kind of justice: If Judah leaves Benjamin behind, he will be held guilty before his father for the wrong reason. If Judah takes Benjamin's place, he will save his brother and his father, but he will be held accountable before Joseph for something he did not do, because neither Judah nor Benjamin had stolen the cup. If Joseph arrests Benjamin, then he would become similar to his brothers in bereaving his father of his children. If Joseph arrests Judah, then he would be unjust, punishing Judah for a crime he did not commit. Now that Judah showed concrete signs of moral transformation, the possible end to the cycle of violence lies in Joseph's power to forgive their wrong doing.

\section{Joseph's Transformation}

What Joseph did to his brothers since they have started coming down to Egypt raised questions about the danger that might be embedded in his dreams to become a ruler. Does becoming a ruler mean being aggressive and abusive towards one's family? Does power result in alienating one's family? Indeed, Joseph walked a very fine line with his brothers that could have jeopardized the meaning of

that Joseph is about to reveal himself because he notes that his brothers have changed." Then later he observes: "Yet, with the passing chapters, the narrator does present Judah as having undergone a gradual transformation." R. Pirson, The Lord of the Dreams: A Semantic and Literary Analysis of Genesis 37-50 (JSOTSup 355; London: Sheffield Academic Press, 2002), 109. See also G.W. Coats, who questions the truthfulness of Judah's moral transformation, and believes that Judah offered to put himself in Benjamin's place because he had no other options: G.W. CoAts, From Canaan to Egypt: Structural and Theological Context for the Joseph Story (CBQMS 4; Washington, DC: Catholic Biblical Association, 1976), 43.

${ }^{13}$ Judah's transformation applies to the rest of the brothers. He is singled out because of the prominent role he played in selling Joseph in Genesis 37. For a different view, see PIRson, The Lord of the Dreams (see n. 12), 109.

${ }^{14}$ M.A. O'Brien questions the nobility of Joseph's character and argues that Judah's speech subtly exposes the flaws of Joseph's character who went too far in testing his brothers to the point of jeopardizing the well-being of his father. M.A. O'BRIEN, "The Contribution of Judah's Speech, Genesis 44:18-34, to the Characterization of Joseph," CBQ 59/3 (1997), 429-447. Lindsay Wilson offers a convincing response to O'Brian's proposal. Wilson writes "in relation to Joseph testing his brothers, Joseph's strong expressions of emotion ( $42: 24 ; 43: 30 ; 45: 1)$, and his expression of concern for their father's well-being $(43: 7,27 ; 45: 3)$, seem to reveal his internal anguish over the pain which was necessarily caused by the test. Yet, it has been argued that Joseph's test was justified by a need to bring about lasting reconciliation to a strife-torn family," see L. WILson, Joseph, Wise and Otherwise: The Intersection of Wisdom and Covenant in Genesis 37-50 (Carlisle, Cumbria, UK: Pternoster Press, 2004), 167-168. 
his dream, confirming the brothers' fear of monarchy. The physical movement between Egypt and Canaan allowed Joseph and his brothers to exchange places and to see the world through the eyes of the other. Now that they have expressed his muted complaint, and have expressed his repressed fear and dismay; now that Joseph has given their fear and anxiety about rulership a voice; now that they have moved transnationally between Egypt and Canaan and from hatred and apathy to sympathy and willingness to sacrifice, it is time for Joseph to come to terms with his own power in relation to his kin. ${ }^{15}$ Now it is Joseph's turn to come to terms with his experience of forced migration and with his rise to power in a way that embraces the vulnerability and transformation that his brothers manifested before his eyes.

As Joseph caused his brothers to walk through his journey of being a stranger, it is his turn now to discover the possibility of embracing his hybrid identity as a Hebrew and as an Egyptian. His integration is evident in that his own brothers did not recognize him, in marrying an Egyptian and in the names he had given to his sons. The name Ephraim means "for God has made me increase in the land of my affliction" (Gen 41:52). Although Egypt for him began with affliction, its enduring memory for him is marked by "being increased by God." Thus, Joseph sees all of his power and wealth and the integration into the Egyptian society as divine gifts that had transformed a land of suffering into a land of blessing and increasing. His first born he named Manasseh, which means "God has made me forget my troubles and my father's house" (Gen 41:51). Now, does this mean that he has come to a better understanding of the troubles that he had experienced from his brothers in his father's house? Or does it mean that he is fitting into the Egyptian society too well to the point that he is willing to forget his father's house? It seems to me based on the fact that the phrase "the house of my father" is preceded by the marker for the direct object, that Joseph is not only talking about forgetting his troubles, but he is also talking about forgetting his father's house. Of course, when one says God made me forget my father's house, it means that this person did not really forget about their father's house. Intentional forgetting does not work. One simply forgets. What Joseph possibly means here is that he is cutting all the ties with Jacob's household. As a migrant, Joseph chose to be only an Egyptian. But because of the famine, Joseph's family appeared before him and he has witnessed their transformation. So now Joseph needs to respond to the new developments in a way that embraces his hybrid identity as a Hebrew migrant and as an Egyptian official. ${ }^{16}$ His ability to reconcile both facets of his identity enables him to embrace his kin as well as his own story as a foreigner.

\footnotetext{
${ }^{15}$ Pirson notes "The authoritarian Egyptian vizier who for quite some time managed to keep his distance from his addressees, is by Judah's speech turned into a vulnerable human being who is no longer able to restrain himself," see Pirson, The Lord of the Dreams (see n. 12), 110.

${ }^{16}$ Heffelfinger helpfully notes that "the reconciliation achieved by the brothers in this narrative is tenuous one and it is not without difficulties. It requires the incorporation of the
} 
In response to Judah's moving speech, Joseph could not control himself (אפך). After dismissing everyone present in his court, Joseph "made himself known to his brothers" (45:1). Although Joseph held political and economic power, and although he seemed to be in control of the threads of the story, in response to his brothers' transformation he has become vulnerable. Exposing his identity could instigate their fear of Joseph's revenge. But by letting himself be known by his brothers, he volitionally removes the mask of harshness, and thus opens the door for reconciliation to advance.

In contrast to Joseph's inability to hold back his emotions, the brothers were not able to "answer" him. They were dismayed at his presence. The expression appears in Qoh 8:3 to exhort the audience not to be terrified in the presence of the king, but to do what the king commands, because the king is too powerful for anyone to tell him "what are you doing?" They were terrified (בהל) as if they have encountered an enemy of war (Exod 15:15; Judg 20:41). Joseph breaks their silence and assures them that he is not seeking revenge or violence against them; there is no reason for them to be horrified. He asks them to "draw near" to him. Earlier in the narrative, when the cup was discovered in Benjamin's sack, the text reported that Judah drew near to Joseph, pleading that he would not get angry with them (44:18). Now, "drawing near" is an invitation offered by Joseph to his brothers as he seeks dismantle their fear. He is not an angry foreign lord, he is their own brother.

Joseph's speech to his brothers in Gen 45:1-15 follows the structure of the first words he uttered to his brothers "I am Joseph. Is my father still alive?" (45:3). Only after addressing how Joseph understands his forced migration in relation to the well-being of his brothers and father that the distance between Joseph and his brothers fully collapsed allowing them to embrace each other (45:15).

As Joseph develops his self-introduction to his brothers: "I am Joseph" becomes "I am Joseph your brother, whom you have sold into Egypt." In these two phrases Joseph holds together in tension the depth of the division and conflict as well as the hopefulness of reconciliation and healing. That siblings decide to sell their own flesh, exposes how powerful jealousy and hatred can be. Prior to being threatened by the death of famine, they fell prey to their hatred, and before they were temporarily thrown into prison in Egypt, they were held captives by their jealousy. The phrase "I am your brother whom you have sold into Egypt" also highlights the possibility of reconciliation. Despite the trauma that Joseph had experienced at the hands of his own brothers, he still calls them brothers. It's the

brother who now exists as both Egyptian and Israelite within the text." And she adds, while Joseph "retains Egyptian power and features, he consistently allows that power to benefit his family from this point in the narrative onwards. No longer are the Hebrews strictly outsiders to Joseph and the Egyptians strictly insiders. The reconciliation of Joseph and his brothers includes his re-incorporation into the family," see Heffelfinger, "From Bane to Blessing" (see n. 9), 316-317. 
family bond that was severely broken, and now it is the same kind of relationship that can mend the wounds.

Joseph does not deny the shameful act of his brothers when they sold him into Egypt, yet he urges his brothers not to let the emotions of "distress and anger" overtake them. While Jacob's children were indignant and very angry on account of the sexual assault that Shechem committed against Dina their sister (34:7), they did not feel the same way about Joseph's suffering. It is Joseph who says what they should have felt when they sold him. It is intriguing to note that it is the brothers who inform the reader how Joseph felt when he was sold by his brothers and now it is Joseph who exposes how the brothers should have felt about what they have done to Joseph. If their feelings of hatred and jealousy have caused Joseph's alienation, the brothers need to be liberated from the emotions of guilt, grief, and anger so that they would not be separated from their brother once again because of being ashamed. ${ }^{17}$

The reason Joseph urges his brothers not to be grieved or be angry with themselves is that he now understands his story of forced migration to be a part of a divine plan. For the outsider observant of the story, it was the brothers who have sold Joseph because of their jealousy and hatred, but for Joseph, who sees the narrative from the view of the resilient migrant, he believes that it was God who has done it. Joseph's way of interpreting his migration story keeps in tension the abhorrence of the brothers' act, namely, "selling" their brother, an act that dehumanized Joseph and turned him into an object to be possessed, and the divine intention of "sending" which treats Joseph as an agent and a partner who works with God to turn death and slavery into life and prosperity. Selling Joseph was intended to send him away from his homeland, to create a distance between him and his family; yet Joseph asserts that it was God who sent him ahead of his family, to be reunited with his family in their new home, Egypt. Indeed, it is a movement away and from, but for the sake of; despite the distance, they are still bound by purpose. Selling Joseph was an attempt to put an end to his dreams for power; now as Joseph reconciles with his brothers, he makes no mention of his dreams, and he recognizes that his power is not over or against his brothers, but for the sake of the well-being of his family. ${ }^{18}$ Judah's transformation entailed will-

${ }^{17}$ Matthew Richard Schlimm draws connections and contrasts between the Cain/Abel story and the Joseph story in relation to the theme of reconciliation. He writes about the encounter between Joseph and his brothers: "It is a moment of reconciliation offered just before the book [of Genesis] closes, allowing readers to see Joseph as an anti-Cain - a brother who has all the power and all the reasons to harm his brothers but instead turns away from anger and, despite the inherent difficulties, offers forgiveness. After a long history of jealousy, anger, sin, and violence, Joseph and his brothers are reconciled," see M. R. Schlimm, From Fratricide to Forgiveness: The Language and Ethics of Anger in Genesis (Siphrut 7; Winona Lake, IN: Eisenbrauns, 2011), 178.

${ }^{18}$ Genung differentiates between the Joseph's brothers' understanding of the dreams and how the narrative itself unfolded the meaning of the dreams. He explains: "Contrary to the broth- 
ingness to put himself in behalf of Benjamin, and Joseph's transformation centers on how he understands his dominion in Egypt to be part of a divine purpose that will ensure the safety of his family. His dominion should be seen a source of life not death; and his rulership should be thought of as a reason for unifying the family rather than dividing it.

Joseph's theological interpretation of his forced migration highlights two important theological claims that counter Jeremiah's message to the Judean community that intended to flee to Egypt from the face of the Babylonians and from the face of the violence that erupted by a certain Ishmael (Jer 41). ${ }^{19}$ Jeremiah was suspicious of the viability of migrating to Egypt and considered it to be a rebellion against God. Take for example the words recorded in the MT of Jer 42:16 "then the sword that you fear shall overtake you there, in the land of Egypt; and the famine that you dread shall follow close after you into Egypt; and there you shall die (See also Jer 42:17; 43:11; 44:12).

Jer 42:17

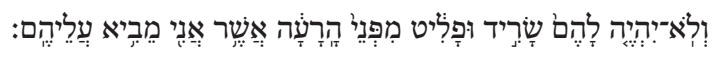

Gen 45:7

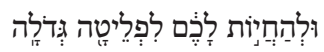

Jer 44:12

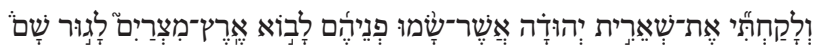

Gen 45:7

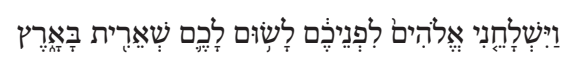

Jeremiah's strong prohibitions that can be summed briefly into "do not go down to Egypt, because you will die there," is countered throughout the story of Joseph where Egypt stands in for life compared to Canaan where death as a result of the famine lies on the horizons. The Joseph narrative does not only uphold that there is life for the Egyptian diaspora, but it also suggests that despite its hardships migration to Egypt is part of a divine plan that will lead to survival. As a forced migrant who have risen to power in a foreign land, Joseph was transformed when he found a transcendent meaning for the hardships he endured. The reconciliation between Joseph and his brothers that was made possible because of migration, would have spoken words of hope to the Judean community that

ers' interpretation of Joseph's dream, the JS [Joseph Story] narrates Joseph's rise to Egyptian prominence in order that he may provide for the welfare of the family during the hardship of the severe famine that would otherwise be the brothers' demise. Instead of becoming a king over the brothers, the brothers bow down to Joseph because he has become sovereign in Egypt, and because he has been put in a position to provide for them, they will come to him in Egypt and receive his care," see Genung, The Composition of Genesis 37 (see n. 1), 128.

${ }^{19}$ Keith Bonder draws brief and quick connections between Jeremiah's descent and Joseph's descent into Egypt, see K. Bonder, After the Invasion: A Reading of Jeremiah 40-44 (Oxford: Oxford University Press, 2015), 157-158. 
was politically fractured after the Babylonian conquest of Jerusalem and was torn between remaining in the land and accepting life in diaspora as a viable and faithful option for their survival.

Some readers can be unsettled by Joseph's determinism present in his interpretation of his forced migration. A broad and uncritical generalization of Joseph's theology might be misused to perpetuate injustice by letting human oppressors go unaccountable for their deeds and by stifling acts of resistance that seeks to speak truth to power. Therefore, it is important to make the following observations. First, this interpretation is not imposed on the powerless in order to quiet their attempts to change the status quo; as a matter of fact, this interpretation is put forth by Joseph, who was victimized by his brothers, and he pronounced it after he had reached power. Second, Joseph does not dilute what the brothers have done to him. Indeed, he described selling him as evil. ${ }^{20}$ Third, we know from the story itself that the characters might attribute to God actions that were planned by human agents. When the brothers found the money in one of their sacks, they wondered why God was treating them this way. Yet the reader knows that it was Joseph who was the master mind of this plan. This is not to dismiss what Joseph is saying as an illusion, but this is pointed out to show the complexity of how human and divine actions are intertwined in the story, because by the same token, if we were to take the words of the brothers seriously, then it is plausible to assume that the narrator is saying that what Joseph had done to their brothers was also part of God's plan. Fourth, Joseph comes out with this theological conclusion not only in order to liberate his siblings from feeling guilty, but in order to liberate himself from the need to revenge. As a forced migrant, he is looking for a transcendent framework of reference in order to give meaning to his experience. Thus, Joseph's view of power has been transformed and his view of being powerless has been transformed since he now reads his life story in a new light; a new light that is not just centered around his own success, but on how his success brings about life and unity to his family, instead of death and divisions. Finally, Joseph's forgiveness is grounded in his deep recognition that he is merely a human, who no matter how much power he may possess he realizes that he is not God. In the second episode of the reconciliation between Joseph and his brothers after the death of Jacob, in Genesis 50:19 Joseph said to his brothers "Do not be afraid! Am I in the place of God?" With these words and with the reference to good and evil, Joseph shows an alternative to the attempt of the first humans who tried to become like God. Knowing good and evil is not bad after all as along as it means breaking the cycle of violence, which is grounded in human

\footnotetext{
${ }^{20}$ For the meaning of this term in the Joseph narrative see: M.R. JACoBs, "The Conceptual Dynamics of Good and Evil in the Joseph Story: An Exegetical and Hermeneutical Inquiry," JSOT 27/3 (2003), 309-338; C. MANDOLFO, “'You Meant Evil against Me:' Dialogic Truth and the Character of Jacob in Joseph's Story," JSOT 28/4 (2004), 449-465.
} 
knowledge of their place in relation to God and in their ability to use their power for the sake of the other and not to oppress the other.

The second part of Joseph's speech to his brothers is concerned with his father. Joseph's question "is my father still alive" is a curious one because he had asked them already about that when they brought Benjamin with them (43:27-28). In the previous incidents, though, the question was about "your father" but here the question is about "my father." By asking the question in this way, Joseph rejoins himself to the family of Jacob. The Egyptian ruler is part of the family. $\mathrm{He}$ urges his brothers to hurry and to go up to "my father." Throughout the previous interactions between Joseph, the Egyptian ruler, he referred to Jacob as "your father," and now after he had exposed his identity to his brothers he can speak of Jacob as "my father." Sending the brothers to inform Jacob that Joseph is alive and well, reverses the previous reports that Jacob's children had to carry to their father. Joseph's message to his father begins and ends with emphasis on Joseph's power in Egypt. Joseph longs to have his father close to him in Egypt so that he would be able to provide land and food for him, for his children, for grandchildren, and for his cattle. Joseph's words to his brothers "hurry and bring my father down" (45:13), reverses Jacob's repeated phrase that his children would bring him down to Sheol grieving. Now Jacob's children are commanded to bring him down, not to Sheol, the land of death, but to Egypt, where the possibility of life awaits them. Twice does Jacob mention his descent into Sheol in sorrow in relation to the descent of his favorite sons, Joseph and Benjamin, into Egypt. While he did not know that Joseph went down to Egypt, he knew that Benjamin was going down to Egypt and in both cases the reader can associate the descent of Joseph and Benjamin down to Egypt with Jacob's words about descending down to Sheol. For Jacob, descent into Egypt might cause - if it does not parallel - descent into Sheol. Yet the story of Joseph clearly shows that Jacob was wrong. Migration to Egypt kept and sustained their life (Gen 45:5, 7). Indeed, when Jacob's children, including Benjamin and Simeon, went up safely to their father, carrying the good news of Joseph's survival and rise to power, the spirit of their father Jacob revived (45:27).

\section{Conclusion}

In this paper, I suggested that interpreters of the Joseph narrative do not have to choose between the two major themes that are prevalent in the novella. The story of Joseph is a diaspora novella that was addressing the needs of a diaspora community and one of those needs had to do with healing the fractured exiled community that had suffered from external as well as internal causes for its forced migration. While migration and estrangement do not always yield healing, transformation and reconciliation, I believe that the experiences of alienation and 
embrace played a significant role in advancing the moral identity of both Joseph and his brothers.

I have suggested that the geographical movement of the brothers between Egypt and Canaan to buy food parallels and effects their moral transformation. The brothers' moral agency that changed from hatred and apathy to solidarity and empathy happened in part because of the way they experienced what it means to be strangers and aliens. Their transformation was evident in the way they were willing to save Benjamin from becoming a slave to the Egyptian master; thus, they did not only save their father from going down to Sheol grieving, they delivered themselves from the politics of jealousy and hatred. Joseph on the other hand, who experienced alienation by his own brothers, needed to find a way to reembrace his brothers as family. When Joseph reinterpreted his forced migration as a mission from God to save his family from the famine, he found a meaning for his hardships in the survival of others; thus, he started to see his power not over or against his brothers, but in relation to and for the sake of his family. In doing that, Joseph, as a model for the diaspora community, was able to embrace his liminal space and to maintain his hybrid identity as both a Hebrew and an Egyptian. Joseph's dreams, after all were not fulfilled in Canaan, but in Egypt. As Joseph and his brothers survived the existential disasters of forced migration and famine, they were not just reconciled with the other that is outside them, in this case life in the Egyptian diaspora, but they were reconciled with the other that is within themselves. Reconciliation here means having empathy for the dreams of the other, voicing the hopes and the fears of the other, and using one's power for the sake of the other. 



\title{
Sapiential Anthropology in the Joseph Story
}

\author{
Konrad Schmid
}

The Joseph story is one of the finest pieces of literature in the Bible. It is also one of the most theologically interesting and challenging texts of Judaism and Christianity. But what is this story actually about? How are we to interpret it? Historical exegesis has at times described its meaning as the voice of the Egyptian diaspora, advocating the legitimacy of Jewish life abroad. ${ }^{1}$ Indeed, the Joseph story seems to serve as a counterpoint to the Deuteronomistic History, which claims that a good life is only possible within Israel and Judah's land and that losing one's land, as reported in $2 \mathrm{Kgs} 17$ and 25, is tantamount to the catastrophe par excellence. The Joseph story instead holds that diaspora life is possible, meaningful, and theologically legitimate. The Joseph story only makes three mentions of God on the level of the narrative itself, all of them occurring in Gen 39 , the chapter describing the events in the house of Potiphar: ${ }^{2}$ God was with Joseph (v. 2), and Joseph's master Potiphar - an Egyptian! - saw that God - the text even uses the Tetragrammaton - was with Joseph (v. 3). V. 6 even mentions

\footnotetext{
${ }^{1}$ See A. Meinhold, "Die Gattung der Josephsgeschichte und des Estherbuches: Diasporanovelle," ZAW 87/3 (1975), 306-324; ZAW 88/1 (1976), 72-93; R. Lux, Josef. Der Auserwählte unter seinen Brüdern (Biblische Gestalten 1; Leipzig: Evangelische Verlagsanstalt, 2001), 237-239; J. Евасн, Genesis 37-50 (HTKAT; Freiburg: Herder, 2007), 692-693; K. Schmid, "Die Josephsgeschichte im Pentateuch," in Abschied vom Jahwisten: Die Komposition des Hexateuch in der jüngsten Diskussion (ed. J.C. Gertz et al.; BZAW 315; Berlin: Walter de Gruyter, 2002), 83-118. See also L.A. RosenthaL, "Die Josephsgeschichte mit den Büchern Ester und Daniel verglichen," ZAW 15/1 (1895), 278-284; IDEM, "Nochmals der Vergleich Ester, Joseph, Daniel," ZAW 17/1 (1897), 125-128. For further references, see F. EDE, Die Josefsgeschichte: Literarkritische und redaktionsgeschichtliche Untersuchungen zur Entstehung von Gen 37-50 (BZAW 485; Berlin: Walter de Gruyter, 2016), 514 n. 5. A different position is taken by E. BLuM and K. WeIngart, "The Joseph Story: Diaspora Novella or North Israelite Narrative?," $Z A W$ 129/4 (2017), 501-521, see also R. Albertz, "Die Josephsgeschichte im Pentateuch," in Diasynchron: Beiträge zur Exegese, Theologie und Rezeption der Hebräischen Bibel. Walter Dietrich zum 65. Geburtstag (ed. T. Naumann and R. Hunziker-Rodewald; Stuttgart: Kohlhammer, 2009), 11-36, especially 20.25; J. WöHRLE, "Joseph in Egypt: Living under Foreign Rule according to the Joseph Story and its Early Intra- and Extra-Biblical Receptions," in Between Cooperation and Hostility: Multiple Identities in Ancient Judaism and the Interaction with Foreign Powers (ed. R. Albertz and J. Wöhrle; JAJSup 11; Göttingen: Vandenhoeck \& Ruprecht, 2013), 53-72.

${ }^{2}$ On Gen 39 and its secondary nature within Gen 37-50, see T. RöMER "The Joseph Story in the Book of Genesis: pre-P or post-P?", in The Post-Priestly Pentateuch: New Perspectives on its Redactional Development and Theological Profiles (ed. F. Giuntoli and K. Schmid; FAT 101; Tübingen: Mohr Siebeck, 2015), 185-201, here 187-189; EDE, Josefsgeschichte (see n. 1), 105.
} 
that God blessed the Egyptian's house for Joseph's sake, of course taking up the famous blessing from Gen 12:3. In other words, the Joseph story states here that Israel's God is also present abroad, and he takes care both of Israelites and foreigners on a global scale.

In addition, the Joseph story takes no offense at mixed marriages (Joseph marries Aseneth, the daughter of a pagan priest), which would be an abomination for the Deuteronomists. One could even characterize the Joseph story as an "anti-Deuteronomistic History" that allows whatever the Deuteronomistic History forbids. It is, so to speak, one of the liberal voices in Genesis-2 Kings. The apocryphal novel of Joseph and Aseneth, which may date to the first century BCE, deals with the theological difficulties that the biblical Joseph story poses and recounts how Aseneth gets rid of all her Egyptian idols and converts to Judaism before marrying Joseph.

However, this historical approach is just one possible angle for interpreting the Joseph story. This text is of course more than a political statement of the Egyptian Jewish diaspora, which, as can be deduced from the so-called Passover letter in the Elephantine papyri, originated during or even prior to the seventh century BCE.

The Joseph story contains other topics deserving of our attention as well. This essay discusses the story's anthropology: How does the Joseph story depict its main characters and their development, and what anthropological insights can one gain from this approach? As will become clear, this question pertains to what is at times identified as the sapiential imprint of the Joseph story.

To begin, a common misunderstanding of the Joseph story should be addressed. ${ }^{3}$ It is not about a morally ideal Joseph that becomes the victim of his morally deprived brothers and then forgives them. Instead, it is about human characters that the narratives portray throughout as developing - and this is true for both Joseph and his brothers. Humans are ambivalent by nature, and their character changes over time.

Such an ambiguous characterization seems especially difficult to prove for Joseph, the seemingly stellar hero of the story. Yet it is both possible and necessary to get a more nuanced impression of his portrayal in the narrative. I shall demonstrate this concentrating on an often neglected element in the story, Joseph's second dream in Gen 37.

As is well known, Joseph reports two dreams to his brothers at the beginning of the story. ${ }^{4}$ The first one deals with the brothers' sheaves bowing down before

\footnotetext{
${ }^{3}$ See K. Schmid, "Josephs zweiter Traum: Beobachtungen zu seiner literarischen Funktion und sachlichen Bedeutung in der Josephsgeschichte (Gen 37-50)," ZAW 128/3 (2016), 374-388.

${ }^{4}$ See J. Lanckau, Der Herr der Träume. Eine Studie zur Funktion des Traumes in der Josefsgeschichte der Hebräischen Bibel (ATANT 85; Zurich: TVZ, 2006), 168-175. See also R. PIRson, The Lord of the Dreams: A Semantic and Literary Analysis of Genesis 37-50 (JSOTSup 355; London: Sheffield Academic Press, 2003), 50-52; J.-D. DöHLING, "Die Herrschaft erträumen,
} 
Joseph's sheaf. The second one reports that twelve stars, the sun, and the moon bow down to Joseph. A number of commentators have evaluated these two dreams as redundant. Hermann Gunkel, for instance, writes:

"Beide Träume bedeuten dasselbe; möglich, daß der Erzähler bei der Doppelzahl der Träume an die beiden Reisen der Brüder nach Ägypten gedacht hat." "Both dreams carry the same meaning, it is possible the narrator thought of the two journeys of the brothers to Egypt by doubling the dreams."

Especially in German scholarship, these evaluations have even led to composition-critical judgments that remove the second dream from the original story. This issue will be discussed below.

But first, we will have to take a closer look at these dreams. The first dream unfolds as follows:

Gen 37:5 Once Joseph had a dream,

and when he told it to his brothers,

ויחלם יוסף חלום - (וגריום

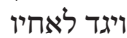

they hated him even more.

$37: 6$ He said to them,

"Listen to this dream

ויוספו עוד שנא אתו ליוד

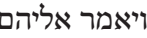

that I dreamed.

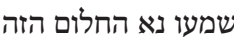

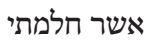

37:7 Behold, we were

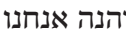

binding sheaves in the field.

מאלמים אלמים בתוך השדה

And behold, my sheaf rose

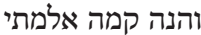

and stood upright;

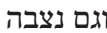

and behold, your sheaves gathered around

it, and bowed down to my sheaf."

37:8 His brothers said to him, "Are you

indeed to reign as king over us?

Are you indeed to have dominion over us?"

ותשתח תסבינה אלמתיכם לאלמתי ותיכם

ויאמרו לו אחיו לאלמתי

המלך תמלך עלינו אחיו

אם משול תמשל בנו עלינו

So they hated him even more

ויוספו עוד שנא אתו תמשל

because of his dreams and his words.

על חלמתיו ועל דבריו

This dream is framed by two references to the brothers' hatred of Joseph in 37:5, 8 . There is even a pun in the Hebrew wording of "they hated him even more": ויוספו עוד שנא אתו which creates a word play with the proper name "Joseph."

Two aspects in the dream are especially noteworthy. First, the dream seems to require no explanation or interpretation. According to the reaction of the brothers, they immediately get the point - namely, that Joseph will have dominion over them. The brothers also take action against the dream's possible fulfillment. This takes me immediately to the second point. This dream is the central, driving force for what is to come in the Joseph story, precisely because Joseph's brothers

die Träume beherrschen: Herrschaft, Traum und Wirklichkeit in den Josefsträumen (Gen 37,511) und der Israel-Josefsgeschichte," BZ 50/1 (2006), 1-30.

${ }^{5}$ H. Gunkel, Genesis (3rd ed.; HKAT I/1; Göttingen: Vandenhoeck \& Ruprecht, 1910), 404, italics original. 
seek to prevent the dream from coming true. Or to state it even more directly, in the brothers' very efforts to hinder the dream's fulfillment, they enable it to come true. Specifically, the brothers' attempt to kill Joseph actually helps Joseph advance to the position of vizier in Egypt. However, he never becomes "king" over his brothers, which is their concern in 37:8.

This motif of an oracle or dream that comes true through someone's effort to thwart it is common in ancient storytelling, but it especially recalls the story of King Oedipus, whose father Laius abandoned him as a baby in order to prevent an oracle from coming true. In the end, the oracle is fulfilled because of this abandonment. Only because Oedipus did not grow up with his parents was he able to murder his father and marry his mother.

Reading on, there is a small detail in Gen 37 that is often overlooked but which bears great significance for the narrative development of the dreams' fulfillment. In Gen 37:14, Joseph is sent by his father Jacob to his brothers in order to check on their "shalom."

Gen 37:14 So he said to him,

ויאמר לו

"Go now, see if it is well

with your brothers and with the flock; and

bring word back to me."

So he sent him from the valley of Hebron.

He came to Shechem,

37:15 and a man found him

לך נא ראה את שלום

as he was lost in the fields;

אחיך ואת שלום הצאן שלום

והשבני דבר

וישלחהו מעמק חברון

ויבא שכמה מעמה

וימצאהו איש שכת בישה

the man asked him,

והנה תעה בשדה אישה וימה

"What are you seeking?"

וישאלהו האיש לאמר

מה תבקש ויאלתו

37:16 He said "I am seeking my brothers,

tell me, please,

where they are pasturing the flock."

ויאמר את אחי אנכי מבקש

הגידה נא לי את רי רים

37:17 The man said,

"They have gone away,

איפה הם רעים

ויאמר האיש הם ניפו

נסעו מזה הישר

for I heard them say,

כי שמעתי אמרים

נלכה דתינה

"Let us go to Dothan."

So Joseph went after his brothers,

and found them at Dothan.

וילך יוסף אחר אחינה אחיו

וימצאם בדתן

This short scene of Joseph searching for his brothers and briefly conversing with "a man" seems to be strange, even superfluous, within the overall Joseph story. Nevertheless, it highlights a specific question that readers might have concerning Joseph's fate: Why did God not prevent Joseph from being endangered by his brothers? This little passage seems to provide an answer. God not only permitted Joseph to engage in a possibly lethal interaction with his brothers, but even sent Joseph deliberately into their arms. 
Why is this so? As Benno Jacob and others have suggested, this "man" who sends Joseph to his brothers seems to be divine. ${ }^{6}$ In various ways, he resembles figures similar to what one finds in Gen 18:2; Gen 32:23-33; and Josh 5. These figures are also called "men," but they are in fact divine messengers (cf. Gen 16:7). While this little scene in ch. 37 is somewhat enigmatic, the "man" here, to my mind, is indeed best interpreted as a divine figure. This conclusion receives further support from the fact that Joseph does not merely "meet" him. Rather, the man "finds" Joseph, just as Joseph in the end "finds" his brothers. If this reading is correct, then according to this passage, God himself provides Joseph with directions for finding his potential murderers.

Readers of the story must exercise considerable patience before learning that Joseph's distress serves the greater good of Israel's survival during the seven years of famine that later occur. At any rate, this small narrative detail highlights that the Joseph story appears to deny the view that anything happening in this world, however cruel, might simply result from an oversight on God's part. On the contrary, God can be perceived even behind actions and events that most people would probably dissociate from him completely. God is the sovereign ruler of the world acting wisely and secretly in the background.

Back to Joseph's initial dreams. Here is his second dream:

Gen 37:9: And he had another dream, and told it to his brothers, saying,

"Look, I have had another dream:

behold, the sun, the moon,

and eleven stars were

bowing down to me."

37:10 But when he told it to his father

and to his brothers,

his father rebuked him,

and said to him,

"What kind of dream is this that you dreamt?

Shall we indeed come, I and your mother

and your brothers, and bow

to the ground before you?"

37:11 So his brothers were jealous of him,

but his father kept the matter in mind.
ויחלם עוד חלום אחר

ויספר אתו לאחיו

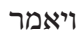

הנה חלמתי חלום עוד

והנה השמש והירח חלום עוד

ואחד עשר כוכבים

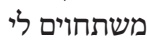

ויספר אל אביו

ואל אחיו

ויגער בו אביו

ויאמר לו בו אביוס

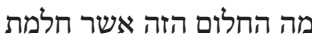

הבוא נבוא אני ואמך ואחיך חלמת החיד

להשתחות

לך ארצה ליקתות ותות

ויקנאו בו אחיו

ואביו שמר את הדבר

This second dream has received little attention in scholarship. Scholars usually consider it a doubling of the first one. As stated earlier, especially Germanspeaking scholars have proposed its removal based on "Literarkritik," which means literary-criticism or, perhaps more unambiguous for an English-speaking

\footnotetext{
${ }^{6}$ B. Јасов, Das erste Buch der Tora. Genesis (Berlin: Schocken Verlag, 1934), 703. See also EDE, Josefsgeschichte (see n. 1), 29 n. 26.
} 
context, composition- or source-criticism. I will illustrate this by tracing Christoph Levin's approach to the dream. He interprets it as an "awkward duplication" ("ungeschickte Verdoppelung") 7 of the first dream which, according to Levin, is also a later addition to the original Joseph story. Reinhard Kratz more recently follows his conclusion and so does Franziska Ede. ${ }^{8}$ Levin's, Kratz's, and Ede's reading results in a simplification of the Joseph story in both narrative and theological terms that to my mind remains unconvincing. The dreams in the Joseph story are an essential narrative constituent of the plot and cannot be removed from it without damaging the whole narrative. ${ }^{9}$

This is also true for Joseph's second dream in Gen 37. Upon closer examination, it becomes clear that this second dream is a literary entity in its own right and not just a duplication of the first dream. Each dream fulfills important narrative functions within the overall story.

In order to describe them, it is helpful to identify the differences between the first and second dream in Gen 37.

Joseph's first dream consists of three scenes, each of which is introduced by הנה , "behold." Joseph's second dream includes only one scene and is likewise introduced by הנה "behold." Yet this point is only formal. What is more important are the differences in the dreams' content.

In Joseph's first dream, everyone involved is portrayed as a sheaf. The eleven sheaves representing Joseph's brothers bow down in front of Joseph's sheaf.

In his second dream, in addition to the brothers, who are represented here by eleven stars, Joseph's parents are present as images of the sun and moon. However, Joseph appears as himself: "The sun, the moon, and eleven stars were bowing down to me." The heavenly bodies are bowing down to Joseph, not to another star representing Joseph.

A final difference involves the fact that Jacob rebukes his son on account of the second dream because it depicts the parents paying honor to Joseph: "What kind of dream is this that you have had? Shall we indeed come, I and your mother and your brothers, and bow to the ground before you?" Such reverence is apparently unthinkable for Joseph's father, Jacob. ${ }^{10}$

\footnotetext{
${ }^{7}$ C. Levin, Der Jahwist (FRLANT 157; Göttingen: Vandenhoeck \& Ruprecht, 1993), 272.

${ }^{8}$ R. G. Kratz, Die Komposition der erzählenden Bücher des Alten Testaments (Göttingen: Vandenhoeck \& Ruprecht, 2000), 283 and n. 68; 324 n. 24; EdE, Josefsgeschichte (see n. 1), 49.

${ }^{9}$ See Schmid, "Die Josephsgeschichte im Pentateuch" (see n. 1); see also Albertz, "Josephsgeschichte" (see n.1). F. AHUis, "Die Träume in der nachpriesterschriftlichen Josefsgeschichte," in "Sieben Augen auf einem Stein" (Sach 3,9): Studien zur Literatur des Zweiten Tempels: Festschrift für Ina Willi-Plein zum 65. Geburtstag (ed. F. Hartenstein und M. Pietsch; Neukirchen-Vluyn: Neukirchener Verlag, 2007), 1-20, wants to assign the dreams only to the post-P edition of the Joseph story.

${ }^{10}$ As a quick note on Joseph's mother in the second dream, interpreters have often wondered how Jacob can speak of Rachel as if she were still alive, given that her death was reported back in Gen 35. Instead of discussing possible harmonizations, I assume that this narratological problem arises from the fact that the Joseph story did not originate as an appendix to Gen
} 
But the second dream is most disturbing not merely because of Jacob's interpretation of it, but also because of the imagery itself. The scene of the heavenly bodies venerating a human being clearly has blasphemous overtones. It bears witness to a certain hubris on the part of its dreamer. As texts like Ps 148:1, 3 or Job 38:6, 7 show, if the heavenly bodies show reverence to anyone, then it is God alone.

Job 38:6: On what were its [i. e. the earth's] bases sunk, or who laid its cornerstone

38:7 when the morning stars sang together

and all the heavenly beings/sons of God shouted for joy?

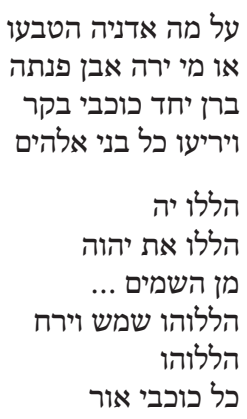

הללו יה

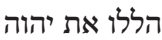

מן השמים ....

הללוהו שמש וירח

הללוהו

כל כוכבי אור

Ps 148:1: Praise YHWH!

Praise YHWH

from the heavens ...

148:3: Praise him, sun and moon;

praise him,

all you shining stars!

Accordingly, Joseph's second dream not only overturns the parent-child relationship but also violates God's exclusive sovereignty over the stars. Joseph somehow dreams himself into a position that elevates him above his parents and which, on top of that, actually should be reserved only for God.

Taken together, Joseph's two dreams in Gen 37 share a common core - Joseph anticipates dominion over his brothers. The second dream, however, also includes some elements that go beyond the first one. The parents are part of the depiction; the specific imagery of the heavenly bodies evokes overtones of hubris; and Joseph appears as himself in the second dream - instead of as a heavenly body like everyone else in his family.

What, then, is the narrative function of Joseph's second dream within the overall Joseph story? Several points are relevant here.

First, it should be highlighted that, unlike the many other dreams in the Joseph story, Joseph's second dream is never really fulfilled. The parents never bow to Joseph. There is an enigmatic note in Gen 47:31b that describes the dying Jacob "bowing" to the head of his bed. ${ }^{11}$ This occurs in the presence of his son Joseph, but it does not imply reverence to Joseph.

12-36 as, e.g., Reinhard Kratz holds (Kratz, Komposition [see n. 8], 281-286). It was probably originally written as an independent novel, see in more detail ScHMID, "Die Josephsgeschichte im Pentateuch" (see n. 1).

${ }^{11}$ See Levin, Jahwist (see n. 7), 307f.; Kratz, Komposition (see n. 8), 281; see also H. SeEBASs, Genesis III: Josephsgeschichte $(37,1-50,26)$ (Neukirchen-Vluyn: Neukirchener Verlag, 2000), 151; R. DE Hoop, Genesis 49 in its Literary and Historical Context (OTS 39; Leiden: Brill, 1999), 328-332.460-464; IDEM, “'Then Israel Bowed Himself ...' (Genesis 47,31)," JSOT 28/4 (2004), 467-480; Евасн, Genesis 37-50 (see n. 1), 521-522; DöHLing, "Herrschaft" (see n. 4$), 20-23$. 
Gen 47:31b: And Israel bowed himself on the head of his bed.

על ראש המטה ישראל

How should we interpret this non-fulfillment? The Joseph story evidently attempts to show that dreams are not always heavenly revelations that can be trusted as such. They may contain human hyperbole that the dreamers add to their content. This point holds true especially for the parents' reverence toward Joseph in his second dream.

Another observation follows logically: Joseph's second dream seems to imply criticism of Joseph's character. According to the Joseph story, there is no black and white separation between Joseph and his brothers. The texts do not portray a perfect Joseph on one side and a rotten bunch of brothers on the other side. Rather, the often overlooked point is that both parties, the brothers and Joseph, are painted in an ambiguous light.

With regard to the narrative development of characters within the Joseph story, which ends in Genesis 50 with a reconciled family, this also means that the Joseph story recounts both the development of the brothers and the development of Joseph himself.

Let us look first at the brothers. There are many nuances among them. First of all, Benjamin holds a special position. Conspicuously, Benjamin makes his initial appearance in the Joseph story in the context of the brother's second journey to Egypt. As Erhard Blum has correctly pointed out, ${ }^{12}$ the belated nature of Benjamin's appearance as a distinct character within the Joseph story arises from the specific focus of the narrator. Up until the second journey to Egypt - Benjamin is first mentioned in Gen 42:4! - the main divide occurs between the brothers and Joseph. For the sake of maintaining this narrative focus, Benjamin is not portrayed as a figure in his own right. This first mention of him is formulated in a highly noteworthy manner:

Gen 42:4: But Jacob did not send Joseph's

brother Benjamin with his brothers,

for he said

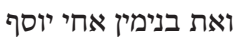

that harm might come to him.

לא שלח יעקב את אחיו אחיוסף

כי אמר יארות

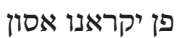

Benjamin is specifically introduced as "Joseph's brother" (singular), and then the text states that he was not sent "with his brothers" (plural) to Egypt. There is a double conception of brotherhood implied here. Being a brother to Joseph (of course, because they have the same mother, Rachel) is something different from being a brother to the rest of his brothers (having the same father, Jacob). We are not told whether Benjamin was part of the assault against Joseph in Gen 37.

${ }^{12}$ E. BLuM, "Zwischen Literarkritik und Stilkritik: Die diachrone Analyse der literarischen Verbindung von Genesis und Exodus - im Gespräch mit Ludwig Schmidt," ZAW 124/4 (2012), 492-515. 
The text apparently has no interest in that question because it focuses exclusively on the confrontation between Joseph and his other brothers. We may assume e silentio that Benjamin either stayed home, or that he was too little to take responsibility for being involved in his brother's actions against Joseph. At any rate, the narrator first presents him to the reader in Gen 42.

Judah is also portrayed in a complicated way. At the beginning of the story, he is one of the instigators and is actively involved in the attack on Joseph. Over the course of the two journeys and Joseph's pressure to bring Benjamin along, he then develops into a responsible character who in his great speech of Gen $44: 18-34^{13}$ - the longest in the book of Genesis - himself offers to stay in Egypt as Joseph's slave in place of Benjamin. His main concern in the offer is not for Benjamin, but for their father Jacob, as the concluding sentence of his speech highlights:

Gen 44:34: For how can I go back to my father if the boy is not with me?

I could not see the evil

that would come upon my father.

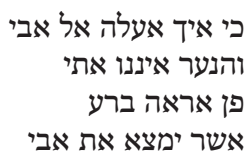

Judah's speech recalls an important motif that binds the overall Joseph story together. After Jacob learns of Joseph's alleged death, he is himself on the verge of death, bringing up a two-part question for the reader: Will Jacob ever see Joseph again, and will Joseph meet his father again before he passes away? In inadvertently returning to this very important point for Joseph, Judah triggers the following scene in Gen 45, where Joseph can no longer hold back his feelings and reveals his true identity to his brothers.

Let us turn finally to Reuben. ${ }^{14}$ He plays a special role in Gen 37, which depicts his efforts to save Joseph from his other brothers' attempt to murder him. These passages, however, are somewhat loosely integrated into their context. It may well be that they are the result of redactional reworking of the Joseph story that took place in order to mitigate the guilt of the brothers by describing Reuben, the first-born, as a potential but unsuccessful savior of Joseph. ${ }^{15}$

But what about Joseph? Genesis 37 introduces Joseph as the beloved son of his father. He is also privileged among his brothers: he does not seem to have to work. Furthermore, he wears a special garment that is otherwise only mentioned in the context of 2 Sam 13, where the princess Tamar also wears a כתנת פסים. The Septuagint translates as $\chi\llcorner\tau \tilde{\omega} \nu \pi \circ$ «

\footnotetext{
${ }^{13}$ M.A. O’Brien, “The Contribution of Judah's Speech, Genesis 44:18-34, to the Characterization of Joseph," CBQ 59/3 (1997), 429-447; J. Joosten, "Biblical Rhetoric as Illustrated by Judah's Speech in Genesis 44.18-34," JSOT 41/1 (2016), 15-30.

${ }^{14}$ See U. SchorN, Ruben und das System der Zwölf Stämme Israels (BZAW 248; Berlin: Walter de Gruyter, 1997).

${ }^{15}$ See, e.g., EdE, Josefsgeschichte (see n. 1), 34-37.
} 
high-flying dreams for which his brothers and father rebuke him. So, Joseph is far from being a perfect character, at least at the beginning of the story.

His character develops over the course of the narrative, especially by means of how he deals with his brothers when they come to him twice in Egypt.

It is never explicitly stated what Joseph intends by imprisoning Simeon and by holding Benjamin back, but it becomes evident from the storyline that he carries out a kind of test. Are the brothers still the same as when they abandoned him in the pit? Or did they change? From Judah's speech in Gen 44:18-34, it becomes clear that Judah and his brothers are now ready to take on responsibility, both for their youngest brother and for their dying father. This brings on the peripety: Joseph is overwhelmed by his emotions and makes himself known to his brothers. Testing the brothers leads to Joseph's change and to their reconciliation.

The main passage in the Joseph story that deals with the formation of Joseph's character appears at the very end. After Jacob's death, the brothers fear Joseph's revenge:

Gen 50:15: Joseph's brothers realized

ויראו אחי יוסף

that their father was dead,

כי מת אביהם

and they said,

ויאמרו

"What if Joseph still bears a grudge against us

לו ישטמנו יוסף ישרו

and pays us back in full for all the wrong

that we did to him?"

50:16 So they approached Joseph, saying,

"Your father gave this instruction

before he died,

50:17a 'Say to Joseph:

I beg you, forgive the crime of your brothers

and the wrong

they did in harming you.'

Now therefore please forgive

the crime of the servants of the God of your father."

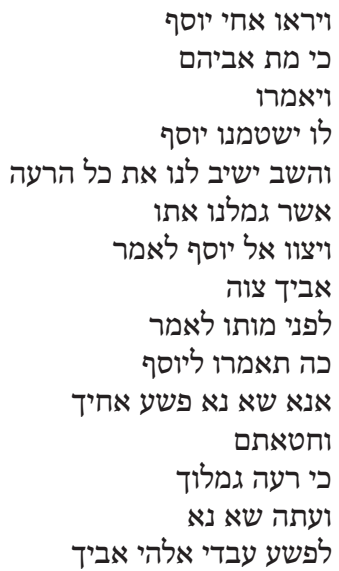

We do not know whether the brothers fabricate this instruction or whether the narrative employs elliptic style (the father indeed had told them, but this is not reported within the story). The latter is more probable given the seriousness of the scene. At any rate, the brothers' plea including the report of the father's instruction seem to suggest that the brothers feel so ashamed that they do not dare ask directly for Joseph's forgiveness. What is Joseph's reaction?

Gen 50:17b: Joseph wept when they spoke to him.

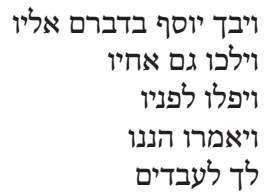

50:18 Then his brothers also wept,

fell down before him,

and said, "We are here

as your slaves." 
Joseph is not angry, instead he shows compassion: He weeps. While the brothers do not ask for forgiveness, they offer themselves as slaves, just as Judah did in his great speech at the end of Gen 44. Genesis 44:16 הננו עבדים לאדנים (We are here as slaves of my lord") and Gen 50:18 הננו לך לעבדים ("We are here as your slaves") are formulated as analogies, with the notable difference in how Joseph is addressed ("my lord"/“you"). Joseph's astonishing reaction follows. He says to them: ${ }^{16}$

50:19: Do not be afraid!

Am I in the place of God?

אל תיראו כי התחת אלהים אני

The reader can easily understand the introduction of Joseph's speech: "Do not be afraid!" Joseph does not plan to punish and/or enslave his brothers.

But then he continues: "Am I in the place of God?" Why does he say this? It could be interpreted, firstly, as an answer to the brothers' reported request for forgiveness: only God can forgive. But this does not seem to be the main focus of Joseph's reaction since he has already told them "Do not be afraid!" One could therefore, secondly, consider the possibility of a self-critical evaluation of Joseph's previous behavior in Egypt towards his brothers. He treated them ruthlessly and arbitrarily, like a tyrant treats his servants. But again, this seems to miss the point. Joseph's remark instead builds a bridge back to his second dream in Gen 37, where he dreamed of himself in the position of God. The stars, the sun, and the moon bowed to him, and now he states, again in front of his brothers, "Am I in the place of God?" The answer to this rhetorical question is, of course, "No." No, Joseph is Joseph, and God is God. Joseph's answer in Gen 50:19 ("Am I in the place of God?") thus reflects back on his second dream in Gen 37:9-11, which depicts Joseph as carried away by hubris. Joseph's second dream is nullified by Gen 50:19. But in order to understand Joseph's answer properly, one must read on:

Gen 50:20: Even though you intended to do harm to me, God intended it for good, as he is doing today, in order to preserve a numerous people.

50:21 So don't be afraid;

I myself will provide for you and your little ones.

In this way he reassured them, speaking kindly to them.

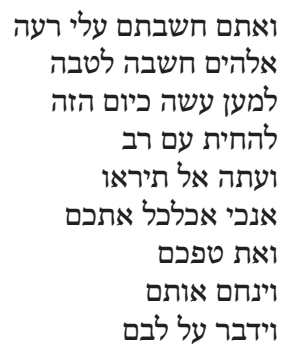

${ }^{16}$ See J. Евасн, "Ja, bin denn ich an Gottes Stelle? (Genesis 50:19): Beobachtungen und Überlegungen zu einem Schlüsselsatz der Josefsgeschichte und den vielfachen Konsequenzen aus einer rhetorischen Frage," BibInt 11/3 (2003), 602-616. 
Joseph explains why he is not in the place of God. The brothers intended to harm, even to destroy Joseph, but even behind these gloomy intentions, Joseph still recognizes God's plan to do the opposite - namely, to save his people.

Why does this statement immediately follow Joseph's assertion about not occupying God's position? What is the sequential logic between 50:19 and 50:20?

One cannot know for sure because there is no explicit explanation of the logic of this sequence. Nevertheless, the following seems plausible: When Joseph accepts his differentiation from God, he is able to discern God's guiding hand in the turmoil of history. Only by bidding farewell to his hubris is he able to gain true knowledge about what happened to him and his brothers. God is God, and man is man: That is a basic conviction of the wisdom tradition - one might mention Qoh 5:1 - and the Joseph story seems to draw on this sapiential insight.

Qoh 5:1 (ET: 5:2): Never be rash with

your mouth, nor let your heart be quick

אל תבהל על פיך ולבך אל ימהר על פליר to utter a word before God,

for God is in heaven, and you upon earth.

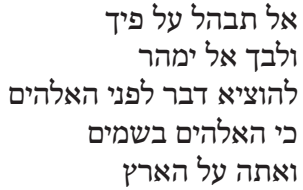

One can identify another sapiential element in the Joseph story in Gen 50:20: the specific notion of how God acts in history appears as an interpretation in Joseph's mouth. The narrator could have addressed his readers directly to identify the moral of the story, stating something like, "Even though the brothers intended to do harm to Joseph, God intended it for good in order to preserve a numerous people, just as he is doing today." But he did not. He lets Joseph state it within the framework of the narrative: "Even though you intended to do harm to me, God intended it for good in order to preserve a numerous people, as he is doing today." What is the difference? The Joseph story does not present God's action in history as a fact about which the reader can be informed or not, but as an interpretation that is accessible and plausible especially for the character of Joseph himself. This is an amazing choice, and it again demonstrates the anti-Deuteronomistic shape of the Joseph story: In the Deuteronomistic History in Deuteronomy through Kings, it is a common occurrence to identify God's will and acts in history on the level of the narrative itself, as if it were an evident truth. The Joseph story thinks differently here. Perceiving God's hand in history is a subtle act of interpretation that cannot be achieved by everyone. The Joseph story appears to place this interpretation of history deliberately in Joseph's mouth. Why? Joseph is the main victim and has suffered the most during the events of the narrative. Therefore, no one other than him qualifies as a legitimate interpreter of his own difficult story that results from God's good will. The same interpretation in the mouth of the brothers, for instance, would be an insult. It is only possible for Joseph himself to make this statement. This essay does not provide the ideal context for a detailed comparison with other biblical formulations of God's action in 
history that are similar or comparable to the Joseph story, such as, for instance, those found in Jonah, Deutero-Isaiah, or in parts of the wisdom literature. At this point, it suffices to introduce a general typology of theologies of history proposed by the Egyptologist Jan Assmann that might be helpful in order to interpret the Joseph story's position in this regard. ${ }^{17}$ Assmann differentiates between three different understandings of how God acts in history in ancient literature including the Bible.

First, many texts promulgate the notion of divine interventions, such as God's splitting of the sea in Exod 14-15 or God's sending down of fire in the story of the competition between Elijah and the prophets of Baal on Mount Carmel in $1 \mathrm{Kgs}$ 18. Second, some texts view history as dependent upon a specific covenantal agreement between God and his people. Chief among them in the Hebrew Bible are the book of Deuteronomy and the Deuteronomistic literature, which connect historical experiences of blessing and curse to Israel's obedience or disobedience to God's will. And third, we also find the notion of a divinely ordained history, as for instance in the book of Daniel or later apocalyptic texts.

If we compare the Joseph story to this conceptual matrix, it does not fit any of the categories very well. It views God's action in history as much more remote and intricate. Identifying God's hand in history is foremost a matter of interpretation that is placed primarily on the shoulders of the victims rather than the victors of events. Nevertheless, it is possible to say that the Joseph story presupposes covenantal interpretations of history, but it criticizes their point of view. Bad behavior such as the brother's is not always punished. It can instead be directed towards a higher good by God himself. The Joseph story does not yet witness to a fully ordained concept of history as known from apocalyptic texts, however. There is human freedom in history, but at the same time also something like hidden divine providence behind history. This point of view between covenantal and ordained concepts of history points to a date between Deuteronomy and Daniel, in absolute terms probably between the sixth and the fourth century вCE.

Why does the Joseph story formulate such a unique position regarding God's involvement in history? This approach results from its sapiential imprint. The Joseph story, at least in parts, belongs to the wisdom tradition. The literature of the wisdom tradition that is found throughout the ancient Near East and also in the Hebrew Bible is very reluctant to speak too bluntly with regard to God. God is God, and humans are humans. If someone were to try to infer a theology of history, then a sapiential approach responds with caution to attempts to construct or

\footnotetext{
${ }^{17}$ See J. Assmann, Das kulturelle Gedächtnis: Schrift, Erinnerung und politische Identität in frühen Hochkulturen (Munich: Beck, 1992), 248-258; English translation: Cultural Memory and Early Civilization: Writing, Remembrance, and Political Imagination (Cambridge: Cambridge University Press, 2011). See also K. Schmid, Theologie des Alten Testaments (NThG; Tübingen: Mohr Siebeck, 2019), 287-307.
} 
propose divine plans in history. Applying human wisdom to the problem of how God acts in history means at the same time acknowledging the limits of human wisdom in that respect. Therefore, the Joseph story concludes the following: Identifying God's hand in history is foremost a personal matter, not a matter of objective certainty. It is impossible to develop an overall conception of God's involvement in history. For Joseph, it is only possible to identify God's hand behind his own fate. His identification of God's providence has also required that he clearly acknowledges his status as a human - he is not in God's place, and it is because of this very awareness that he's able to recognize God's acts in his own life, though at so many times it may have looked as if he had been abandoned by God.

Finally, Joseph's transformation from a spoiled youngster to a responsible leader is also a wisdom topic: The story speaks of character formation through experience and education.

What is the position of the Joseph story within the wisdom tradition, and what does this imply for its dating? The notion of the Joseph story having a sapiential imprint at all has become a common assumption in scholarship ever since Gerhard von Rad. ${ }^{18}$

However, von Rad's approach was informed only by the few textual and thematic links he identified between the Joseph story and the early wisdom tradition. For instance, von Rad pointed out parallels between Gen 39, the story about the affair with Ms. Potiphar, and Prov 23:

Prov 23:27-28: For a prostitute is a deep pit;

כי שוחה עמקה זונה an adulteress is a narrow well.

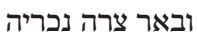

28 She lies in wait like a robber

and increases the number of the faithless.

אף היא כחתף תחרה נכריה

ובוגדים באדם תוסף כתרב תאר

Or regarding Joseph's talks with his brothers, von Rad hints at Prov 16 or 25, which appreciate the power of the word:

Prov 16:23: The heart of the wise makes their speech judicious, and adds persuasiveness to their lips.

לב חכם ישכיל פיהו ועל שפתיו יסיף לקח פחה

Prov 25:11: Like apples of gold in a setting of

תפוחי זהב במשכיות silver is a word fitly spoken. כסף דבר דבר על אפניו

Finally, von Rad saw a link between the so-called quintessence of the Joseph story in 50:20-21 and sayings like Prov 16:9 and 20:24:

Gen 50:20: Even though you intended to do harm to me, God intended it for good,

ואתם חשבתם עלי רעה אלהים חשבה לטבה חלי

\footnotetext{
${ }^{18}$ G. von RaD, "Josephsgeschichte und ältere Chokma," in Gesammelte Studien zum Alten Testament (4th ed.; ed. G. von Rad; TB 8; Munich: Kaiser, 1958), 272-280; IDEM, "Die Josephsgeschichte," in Gottes Wirken in Israel. Vorträge zum Alten Testament (ed. O.H. Steck; Neukirchen-Vluyn: Neukirchener Verlag, 1974), 22-41.
} 
as he is doing today,

in order to preserve a numerous people.

למען עשה כיום הזה

50:21 So don't be afraid;

I myself will provide for you

and your little ones.

להחית עם רב כיב

ועתה אל תיראו

In this way he reassured them,

אנכי אכלכל אתכם איראו

ואת טפכם

וינחם אותם טפס

speaking kindly to them.

וידבר על לבם אותם

Prov 16:9: The heart of a human plans his way,

but YHWH directs his step.

לב אדם יחשב דרכו

ויהוה יכין צעדו יחשב

Prov 20:24: All the steps of a man are ordered by YHWH;

how can a human understand his own way?

מיהוה מצעדי גבר

ואדם מה יבין דרכו גברו

Von Rad was interested in dating the Joseph story to the period of what he called the "Solomonic enlightenment," and he therefore looked for parallels in the older wisdom tradition.

But as especially Michael Fox has pointed out, the Joseph story is more similar to the wisdom tradition as witnessed, e. g., in the book of Daniel than in the older parts of the book of Proverbs. Fox writes:

"The concept of wisdom in the Joseph story is affiliated with the pietistic and inspired wisdom of Daniel rather than with the ethical and practical wisdom of Wisdom literature." 19

However, in light of this analysis of Joseph's character formation and transformation as depicted in Gen 37-50, it is fair to say that the Joseph story combines the ethical and practical concept of wisdom with its inspired notion by conceiving of the former as presupposing the latter.

The Joseph story thus forms a bridge between the older and the younger wisdom tradition, pointing out the necessity of character formation in order to gain inspired and theological valuable insights.

Thus, the Joseph story does not seem to be as late as the Daniel narratives in Dan 1-6. It is still developing the intellectual notions of inspired dream interpretation in Daniel. Nevertheless, as a diaspora novella, the Joseph story presupposes the existence of Israelites or Judeans in the diaspora, which leads to a terminus a quo in $722 \mathrm{BCE}$. On the other hand, it cannot be later than the Priestly Code. Otherwise one would expect the Joseph story to create a smoother bridge between the Genesis and the Exodus traditions than it currently does. One can point out merely the divergent depictions of Pharaoh and the Israelites in Gen 37-50 versus Exod 1-15 and the narrative un-doing of the Joseph story in Exod 1:6-8. The connection between Genesis and Exodus is, by contrast, firmly established by the Priestly Code. Why would the Joseph story create narrative difficulties if it were a post-P insertion?

${ }^{19}$ M.V. Fox, "Wisdom in the Joseph Story," VT 51/1 (2001), 26-41, here 40. 
This leaves us with a terminus ante quem in the late Neo-Babylonian or, more likely, in the early Persian Period. Since the Joseph story's final passages focus on the cohesion of all the twelve tribes of Israel, it is more plausible to date it after $587 \mathrm{BCE}$ than between 722 and $587 \mathrm{BCE}$, but this issue remains open to debate. ${ }^{20}$

However, how to date the Joseph story is much less important than analyzing and understanding its basic thoughts and theological sophistication. Nevertheless, it can help to recognize the historical framework of its ideas and thus gain an even better and deeper understanding of its ideas.

\footnotetext{
${ }^{20}$ See T. Römer, “Joseph Story” (see n. 2), 189-195 for an overview. Römer opts for a post-P date, whereas Blum and WeIngarT, "The Joseph Story" (see n. 1), argue for an earlier setting in the eighth century вСЕ.
} 


\title{
The Joseph Story from an Egyptological Perspective
}

\author{
Camille Guerin*
}

The Egyptological commentary on the Joseph story that I will present here aims to propose not only a date of composition for the Joseph story but also the historical context of its author(s). Rather than attempting to show a direct connection between the Egyptian and Hebrew elements in the narrative, the present study will take a more comparative approach. Situating the Egyptian elements of the narrative within the historical realities of ancient Egypt will provide more information about the Joseph story's date of composition. Although a number of Egyptian elements are discernible, only those that shed light on when and why Genesis 37-50 were written will be dealt with here.

\section{Commerce and Agriculture}

\subsection{A Semitic Slave in Egypt}

In order to bring Joseph to the land of the pharaohs, the biblical author narrates that Joseph was sold as a slave to an Egyptian named Potiphar. On several occasions, the text of Genesis mentions caravaneers trafficking in slaves. Studying slavery in ancient Egypt is complicated, since it is often difficult to know the legal status of the servants and workers mentioned in the texts. We know that the Egyptians obtained slaves primarily through war with their neighbors. They brought back prisoners of war but also women and children, since the conquered region had become the property of the king. Slaves experienced one of several different fates: The king sold them, they were made into workers at various temple workshops, or Egyptian soldiers could keep them as booty. ${ }^{1}$ This contingent was supplemented by trade with neighboring regions, although not much is known about the conditions under which this took place. ${ }^{2}$

* I am grateful to Thomas Römer and Konrad Schmid for having invited me to present my work at the international conference "The Joseph Story between Egypt and Israel," which took place on 15-16 June 2018 in Lausanne.

${ }^{1}$ J. Vergote, Joseph en Égypte: Genèse chap. 37-50 à la lumière des études égyptologiques récentes (Louvain: Publications universitaires, 1959), 16-17.

${ }^{2}$ Ibid., 17. 
Most often, the pharaohs entered into war with the lands to the northeast. After the dark period of the Hyksos domination, a rapid renaissance began under the first kings of the Eighteenth Dynasty. Yet Egypt's economic recovery required raw materials that the Theban treasury did not have. The fastest way to procure such materials was through war, which is one of the factors that could explain why the Egyptians attacked their neighbors to the northeast. Each victory resulted in booty and large numbers of prisoners; ${ }^{3}$ it is thus no coincidence that in documents mentioning slaves' place of origin, they are most often from this region. A number of documents refer to Syro-Palestinian slaves, such as Papyrus Bologna 1086, which mentions a Syrian brought to Egypt by boat, ${ }^{4}$ while another text mentions young slaves from Kerke in Palestine brought to serve in the entourage of Ramesses II. ${ }^{5}$ Thus, the presence of Syro-Palestinian slaves in Egypt was not a rare occurrence.

In contrast, during the Middle Kingdom, the relations between Egypt and the lands to the northeast were friendlier, and military campaigns were rare. Regarding Asiatics in the Nile valley during this period, it is difficult to confirm the presence of prisoners. It is possible that instead of being part of war booty, they were sold by their kinsfolk to the Egyptians. Yet international trade in slaves does not appear in Egyptian sources and thus limits the possible evidence of this to the example of Joseph. ${ }^{6}$ Another possibility is that individuals came to Egypt on their own volition in order to look for work. ${ }^{7}$ For the Hellenistic period, we know from Strabo that the agents of Zenon went to Palestine (namely, to Gaza) in search of spices and slaves, and that commercial envoys were sent there. The agents of Apollonius purchased slaves, which were in high demand in Alexandria. ${ }^{8}$ It is thus only in the Hellenistic period that we find a real parallel to the Joseph story, that is, a foreign slave who is purchased rather than being brought to Egypt after a military victory. ${ }^{9}$

${ }^{3}$ G. Posener, "Une liste de noms propres étrangers sur deux ostraca hiératiques du Nouvel Empire," Syria 18 (1937), 183-197, here 183.

${ }^{4}$ A. E.-M. BAKIR, Slavery in Pharaonic Egypt (CASAE 18; Cairo: Institut français d'archéologie orientale, 1952), 70; W. Wolf, “Papyrus Bologna 1086,” Z̈̈S 65 (1930), 89-97; J. VERGote, Joseph (see n. 1), 18.

${ }^{5}$ J. Pirenne and B. VAN de Walle, Vente et lougge de services, Vol. 1 of Documents juridiques égyptiens (ed. J. Pirenne; AHDO 1; Bruxelles: Nouvelle société d'éditions, 1937), 33-38.

${ }^{6}$ G. Posener, "Les asiatiques en Égypte sous les XII et XIII ${ }^{\mathrm{e}}$ dynasties," Syria 34 (1957), 145-153, here 158.

${ }^{7}$ D. B. ReDFord, A Study of the Biblical Story of Joseph: (Genesis 37-50) (VTSup 20; Leiden: Brill, 1970), 197.

${ }^{8}$ C. PréAux, Les Grecs en Égypte d'après les archives de Zénon (Collection Lebègue 78; Bruxelles: Office de publicité, 1947), 58.

${ }^{9}$ Vergote, Joseph (see n. 1), 20. 


\subsection{Trade in Resins and the Domestication of the Camel}

Gen 37:25 is a very important verse, providing us with several different pieces of information. On a first reading, the Ishmaelites in this verse seem to be merchants who trade with the different countries that they pass through. At the end of the verse, we learn that they are headed toward Egypt, with the aim of selling various products such as tragacanth gum, resin, and labdanum. Does this mean that at that time trade existed on a particular route that passed by Egypt? Does the reference to camels allow one to conclude that the camel was domesticated and known in the land of the pharaohs during a particular period that can be identified?

Resins and gums played an important role in everyday life and in the economy of Egypt during the entire pharaonic period. Many of these served as cleaning agents for the body, clothes, and home. ${ }^{10}$ The aromatic substances that are mentioned most frequently in Egyptian literature and inscriptions are incense and myrrh. ${ }^{11}$ One of the oldest known references to Egypt's trade with the land of Punt, where both incense and myrrh could be found, dates to the fifteenth century BCE. It describes how Queen Hatshepsut wanted to cultivate myrrh trees in Egypt. One can deduce from this that at the time when trade with the land of Punt declined, the Egyptians, whose demand for aromatic substances did not diminish, looked to Arabia and the caravan routes. ${ }^{12}$

Scholars generally agree that commercial relations between Arabia and the Levant began to develop beginning in the Iron Age II with the establishment of the so-called "incense route." As has already been mentioned, the information that is currently available suggests that the origins of trans-Arabian caravan trade should be sought beginning in the thirteenth and twelfth centuries BCE in the context of Egypt's presence in southern Palestine, whereas Egypt's procurement of incense from Punt ceased suddenly and definitively around the twelfth century. ${ }^{13}$ From the time of its emergence, the incense route was a coveted asset for both local and international powers. One of the reasons for the expansionist aims of the Assyrian, Babylonian, Persian, and, later, Hellenistic and Roman Empires was to control this new line of communication. This allows us to posit interactions between imperial and regional powers in the reference to nomads transporting incense in Gen 37:25. ${ }^{14}$ The economy of the tribes in the lowlands bordering the desert was based on irrigated agriculture and on the

\footnotetext{
${ }^{10}$ P. Montet, La vie quotidienne en Égypte au temps des Ramsès (Paris: Hachette, 1946), 273.

${ }^{11}$ A. Lucas, Ancient Egyptian Materials and Industries (3rd ed.; London: E. Arnold, 1948), 110-111; Vergote, Joseph (see n. 1), 11.

${ }^{12}$ D. Champault et al., La route de l'encens (Paris: Imprimerie nationale, 1996), 46-61.

${ }^{13}$ M. JAsmin, "Les conditions d'émergence de la route de l'encens à la fin du II ${ }^{\mathrm{e}}$ millénaire avant notre ère," Syria 82 (2005), 49-62, here 49.

${ }^{14}$ Ibid., 50.
} 
cultivation of incense and myrrh trees. These products were brought by caravan to the markets of the eastern Mediterranean and Egypt. ${ }^{15}$

It is now necessary to consider the reference to camels in Gen 37:25. The emergence of caravan trade was intimately connected to the domestication of the camel, which enabled the crossing of vast expanses of desert and thus revolutionized the trade routes of the ancient Near East. According to several scholars, these two processes go hand in hand both thematically and chronologically. ${ }^{16}$ The domestication of the camel seems to have taken place in successive stages and is generally thought to have been completed prior to the first millennium все. Before the use of camels, the donkey could also be used on equally long journeys along the desert fringe. We know with certainty of a "route" that was in existence by the seventh century вСЕ. Opening such a route did not require much work: All that was required was to identify the shortest but also the safest route, with access to water at regular intervals. Merchants could transport products that were found only in their country with the help of the camel, whose endurance was legendary. ${ }^{17}$

Undomesticated camels were common; depictions of them can be found on the cliffs alongside the Nile and as camel figurines dating to the Predynastic period. ${ }^{18}$ The various representations of this beast of burden extend from the Predynastic period to the time of Ramesses II. Some think that the domestication of the camel was the work of a Semitic group living in remote parts of the Arabian desert, probably in the fifth or fourth millennium. The domesticated camel seems to have been limited to Arabia during that time, and it is from there that the sporadic representations of the camel in Egypt seem to come. ${ }^{19}$

The wider domestication of the camel took place so suddenly in particular periods and in a series of concentric waves (at the turn of the first millennium in Arabia and Mesopotamia, during the Persian period in Egypt, and during the Roman period in North Africa) that it is possible to imagine that there was a single center of domestication in Arabia. ${ }^{20}$ For other scholars, there is no evidence for the existence of the domesticated camel in Egypt before the Ptolemaic period. In their view, the depictions and figurines that others identify as the camel are not conclusive, and since there is no word for "camel" in Egyptian, they

${ }^{15}$ Champault et al., La route de l'encens (see n. 12), 46-61.

${ }^{16}$ Vergote, Joseph (see n. 1), 13; RedFord, A Study of the Biblical Story of Joseph (see n. 7), 192-193.

${ }^{17}$ Champault et al., La route de l'encens (see n. 12), 46-61.

${ }^{18}$ W. F. Albright, The archaeology of Palestine (Pelican Books 199; Harmonsworth: Penguin Books, 1949), 206-207.

${ }^{19}$ Vergote, Joseph (see n. 1), 15; H. Epstein, "Le dromadaire dans l'Ancien Orient," RHS $7 / 3$ (1954), 247- 268.

${ }^{20}$ X. DE Planhol, "Nomades et pasteurs," Revue Géographique de l’Est 1/3 (1961), 291-310, here 294-295; R. W. Bulliet, "Le chameau et la roue au Moyen-Orient," Annales 5 (1969), 10921103, here 1094-1095. 
conclude that the Egyptians did not know of it. ${ }^{21}$ One cannot ignore, however, the aforementioned commercial route that developed over time. Thus, at some point, the Egyptians must have seen merchants accompanied by their camels.

One of the most recent studies to link the "incense route" with the domestication of the camel concludes that the domestication of the camel first occurred in southeastern Arabia during the third millennium BCE. Thanks to archaeological excavations in western Arabia, we know of several bedouin sites from the third millennium but especially from the end of the second millennium where camel bones were found. However, the widespread use of the camel in the Levant and Mesopotamia began only in the eighth century BCE. In Egypt, it was only in the Ptolemaic period that camels began to be used on a large scale. They were used for the transportation of commodities, particularly in arid areas, and later they were used in warfare and plundering. ${ }^{22}$ In the end, whatever the initial motivations were for the domestication of the camel by sedentary populations in southern Arabia, it was without doubt the caravan trade on the incense and spice routes that was the major reason for its spread into northern Arabia. Moreover, its spread into Egypt during the Persian and Hellenistic periods can be connected to the rise of large-scale trade with the Seleucids to the east. ${ }^{23}$

In light of this information, it seems difficult to assign a specific date to the trade that is described in the Joseph story. At the same time, however, it is difficult to imagine that trade as important as that in gum and resin could have taken place through the use of camels without any Egyptian document referring to this, given that the donkey is referred to constantly. The reference to camels in the biblical text is thus more easily understandable if attributed to a late redactor. ${ }^{24}$ Indeed, under the control of the Persian Empire and later the Hellenistic kingdoms, the incense route became more extensive, both in terms of the quantity of commodities traded as well as in the infrastructure that developed along the route. Waystations were established at regular intervals for the caravans, and the number of such sites attests to the importance of the route as well as the profits that such trade generated. ${ }^{25}$ Given that the products cited in Genesis do not allow us to date such trade, it is the establishment of this commercial route, apparently associated with the domestication of the camel, that might allow us to establish a chronological limit (terminus a quo) to the trade that is referred to in Gen 37:25.

${ }^{21}$ B. Midant-Reynes and F. Braunstein-Silvestre, "Le chameau en Égypte," Or 46 (1977), 337-362.

${ }^{22}$ Jasmin, "Les conditions d'émergence" (see n. 13), 54-55.

${ }^{23}$ De Planhol, "Nomades et pasteurs" (see n. 20), 295.

${ }^{24}$ Midant-Reynes and Braunstein-Silvestre, "Le chameau en Égypte” (see n. 21), 353354.

${ }^{25}$ JASMin, "Les conditions d'émergence" (see n. 13), 58-59. 


\subsection{Agrarian Policy}

During the years of famine, Joseph establishes a system providing food to the entire population. The situation unfolds in several stages. At the beginning, Joseph sells grain to the people and, in this way, amasses all the silver of the lands of Egypt and Canaan. This continues in exchange for military service from the people and then in exchange for their land. In the end, the entire country belongs to the pharaoh.

Beginning in the Neolithic period, and certainly from the reign of Scorpion II onward, Egypt's fertile soil was cultivated through irrigation farming. The organization of arable land into estates is generally attributed to king Djoser. The land belonged to the pharaoh, and the nobles were merely its managers. They sent a portion of the production to the royal treasury in the form of a rent in kind. ${ }^{26}$ Upon first glance, the prevailing principle in ancient Egypt seems to have been that of redistribution relying on large-scale production. That is to say, a central authority appropriated a large part of the land's resources and redistributed them to the rest of the population. While this model can be observed in several ancient societies, the Egyptian model seems to have been characterized by a certain degree of decentralization, which meant that record-keeping took on a particularly important role. Thus, there would not have been a large, central granary storing the produce of the entire country, given its vast extent. Rather, there would have been multiple granaries belonging to a variety of institutions that stored the agricultural surplus produced by the rural population. Grain was amassed in fields, transferred to temple granaries, and distributed to those who worked on the royal tombs. ${ }^{27}$ When all of the work of the harvest was completed, two nobles of the estate - the granary scribe and the grain measurer - carried out their tasks of measuring the piles of grain and transferring them to the granary. In every period, granaries for wheat were built following the same general plan. For smaller-scale production, in contrast, a different type of granary was preferred; this type of granary is commonly found during the New Kingdom. Remains of such granaries are found in large numbers among the ruins of houses in Amarna. These granaries, of which three to five were placed side by side, were most often found in the immediate vicinity of the noble's residence. A double silo of the same type but of much larger dimensions - as we can imagine the Egyptian granaries mentioned in the Hebrew Bible - was also found in Amarna, at the edge of the eastern part of the city. ${ }^{28}$

\footnotetext{
${ }^{26}$ P. Posener-Krieger, “Greniers et troupeaux d'Égypte," MoBi 41 (1985), 15-18, here 15.

${ }^{27}$ D.A. Warburton, State and Economy in Ancient Egypt: Fiscal Vocabulary of the New Kingdom (OBO 151; Fribourg and Göttingen: University Press and Vandenhoeck \& Ruprecht, 1997), 313.

${ }^{28}$ A. ERman and H. Ranke, La civilisation égyptienne (Paris: Payot, 1954), 585-586.
} 
It seems logical to assume that the sole proprietor of the land was the king. $\mathrm{He}$ could, however, delegate his authority permanently to royal temples and provincial deities or temporarily to central or local administrators. ${ }^{29}$ Since in theory the king was the sole holder of the land, the passage in Genesis could correspond to every historical period between the earliest dynasties and the Ptolemaic period. As regards the $20 \%$ tax levied on the population, it is difficult to draw definitive conclusions. The information that we have on taxation in ancient Egypt is too limited to establish the percentages levied by the state on harvests during successive periods. Thanks to the Papyrus Wilbour, we know that during the Twentieth Dynasty the most common fiscal levy was the norm of five measures of grain for every aroura. Nevertheless, it would be going too far to interpret the $20 \%$ tax in the biblical text as a reflection of this common fixed rate. ${ }^{30}$

An element of the biblical text that is particularly interesting in the attempt to identify a particular historical reality is the reference to the exemption of priestly land. There are a variety of references to the privileges accorded to the priesthood during the pharaonic period. Different actions were possible, particularly the giving of land. From the Old Kingdom, we have a dedicatory stela bearing the Edict of Pepi I, in which the king donates a funerary estate to the god Min. This results in the forfeiture of royal authority over this territory: The king no longer makes any requisition on the land, no longer has the right of passage, and no longer imposes a royal tax on the land. The estate is thus transferred to the temple, free of all obligations vis-à-vis the royal administration. It is clear, however, that in theory the king remains the owner of the estate. This principle of donation remained largely unchanged during the entire pharaonic period, at least up to the Macedonian conquest. ${ }^{31}$ Regarding the lands belonging to the temples, however, the royal administration retained a right of inspection and doubtless also a right to levies on revenues, given that the temples were only second-degree owners of the land. ${ }^{32}$

During most periods, we have evidence that priests were taxed; an exception is Papyrus Wilbour, which indicates that this was not the case during the reign of Ramesses V. Indeed, the Egyptological evidence suggests that during this period the royal government was rapidly losing - or had already lost - its hold on the major priesthoods. ${ }^{33}$ The royal decrees granting administrative privileges to temples proved, by their very existence, that there was not a general law giving

${ }^{29}$ B. Menu, "Fondations et concessions royales de terres en Égypte ancienne," DHA 21/1 (1995), 11-55, here 13-14.

${ }^{30}$ A.H. Gardiner, Commentary, Vol. 2 of The Wilbour Papyrus (ed. A. H. Gardiner; Oxford: University Press, 1948); RedFond, A Study of the Biblical Story of Joseph (see n. 7), 237.

${ }^{31} \mathrm{R}$. WeILL, Les décrets royaux de l'Ancien Empire égyptien (Société française des fouilles archéologiques; Paris: P. Geuthner, 1912), 40-43; Menu, "Fondations" (see n. 29), 24-25.

${ }^{32}$ Menu, "Fondations" (see n. 29), 16.

${ }^{33}$ W.F. Edgerton, "The Government and the Governed in the Egyptian Empire," JNES 6 (1947), 152-160, here 156-157. 
similar privileges and immunity to all temples. Rather, it was a sort of administrative ideal that was acknowledged by the pharaohs, although they did not always conform to this ideal. ${ }^{34}$ One particular document could suggest that certain types of immunity were nevertheless given; this is the Nauri Decree of Seti I, which refers to immunity offered to a particular temple in Abydos in order to protect the interests of Nubia. Apparently, this text does not mention any sort of exemption. ${ }^{35}$

Finally, we can state that the political situation that most closely matches the biblical text is the Saite period. Papyrus Rylands IX reveals that, during the Twenty-Sixth Dynasty, the temples of the Two Lands could not be taxed except in extenuating circumstances. The Saite kings made efforts to strengthen the priesthood and also made significant donations to the gods, especially to Neith, the patron goddess of the Saite capital. We also know that during the Ptolemaic period the priesthood received a salary from the state, ${ }^{36}$ and both Herodotus and Diodorus of Sicily state that temples were tax-exempt. Although the biblical depiction of Joseph's agrarian policy could be an invention of the Hebrew narrator, it can also be asked whether the Joseph story might reflect to a certain extent the decisions taken by the pharaohs in later periods, particularly during the Twenty-Sixth Dynasty. ${ }^{37}$

\section{Rites, Customs, and Beliefs}

Let us now examine the Egyptian ritual called $n b n$ hsw.t, that is, the "gold of honor." When one reads Gen 41, the giving of a necklace and of clothes of fine linen recalls an award ceremony for an Egyptian high dignitary. At the same time, one should not confuse this with certain scenes in which men and women receive large necklaces; these are not "rewards" but are the salaries paid to workers, who also received oil, linen fabric, and clothes. This honorific act is attested beginning in the Sixth Dynasty in the tomb of a nomarch of Elephantine named Sabni, ${ }^{38}$ and it is especially during the New Kingdom that its attestations become more numerous. This ceremony included the awarding of a long golden necklace. Also attested are two double bracelets for the biceps, one for each arm, as well as bracelets worn on both wrists. ${ }^{39}$

\footnotetext{
${ }^{34}$ Vergote, Joseph (see n. 1), 191.

${ }^{35}$ Edgerton, “The Government" (see n. 33), 156-157.

${ }^{36}$ REDFORD, A Study of the Biblical Story of Joseph (see n. 7), 238-239.

${ }^{37}$ Ibid., 239; D. Nocquet, "Genèse 37 et l'épreuve d'Israël: L'intention du cycle de Joseph," ETR 77/1 (2002), 13-35, here 30.

${ }^{38}$ Vergote, Joseph (see n. 1), 122.

${ }^{39}$ Ibid., 125; S. BINDER, "Joseph's rewarding and Investiture (Genesis 41:41-43) and the Gold of Honour in New Kingdom Egypt," in Egypt, Canaan and Israel: History, Imperialism, Ideology
} 
This ceremony was not restricted to a particular social stratum: soldiers, priests, sculptors, and viziers could all receive the "gold of honor." The awards given by the king could be many. The "gold of honor" was one ceremony among many others, even if it seems to be the most prestigious. ${ }^{40}$ It is also possible to note a difference between the objects received by civilians and soldiers. ${ }^{41}$

In addition, once the pharaoh gives Joseph his reward, he makes him ride on one of his chariots in order to be paraded amidst the crowd that was with him. The presence of the crowd was essential to such a ceremony; it was appropriate to honor the hero of the day in splendor, which required movement, acclamations, and great gestures to honor the person being decorated. ${ }^{42} \mathrm{~A}$ chariot procession is attested several times in award scenes, in which the person being celebrated wears the objects he has just received. ${ }^{43}$

In light of this information, it seems that Gen 41:40-43 describes a purely Egyptian ceremony, which celebrated the acquisition of a privileged status with respect to the king. It is for this reason that such scenes are often described in texts or depicted on the tomb walls of important figures. Joseph achieved such a high office in Egypt that it may have seemed obvious to the Hebrew author to depict him as being honored with this ceremony. This author thus used older traditions in his text, namely, those which fit best with the situation in which Joseph lived.

\subsection{Jacob's Embalming}

Genesis 50:2-3 underscores Joseph's attachment to his adopted country. After the death of his father, Joseph has him embalmed according to Egyptian custom. This might seem surprising, since Joseph believes in a different deity than the Egyptians do, which means that Joseph must have had a completely different conception of life after death and the way of reaching it. In addition to this is the fact that Jacob did not want to be buried in Egypt, but instead in the land of his ancestors. In the passage under consideration, one particular element attracts our attention, namely, the reference to "physicians."

The individuals tasked with mummification in ancient Egypt were embalmerpriests. They dealt on a daily basis with cadavers that they had to embalm and thus must have acquired irreplaceable knowledge and practical skills. In contrast, physicians had the task of taking care of living person and did not a priori deal with issues related to death. Yet both professions seem to have shared one

and Literature. Proceedings of a conference at the University of Haifa, 3-7May 2009 (ed. S. Bar et al.; Leiden: Brill, 2011), 44-64, here 46.

${ }^{40}$ Binder, "Joseph's rewarding” (see n. 39), 48-49.

${ }^{41}$ Vergote, Joseph (see n. 1), 128.

42 J. VANDIER, Bas-reliefs et peintures, scènes de la vie quotidienne, Vol. 4 Manuel d'archéologie égyptienne (ed. J. Vandier; Paris: A. et J. Picard, 1964), 252.

${ }^{43}$ Binder, "Joseph's rewarding” (see n. 39), 57. 
particular function, namely, healing the body. ${ }^{44}$ It seems that both the physician and the embalmer received part of their education in the "House of Life." It was only after this that the two career paths diverged. ${ }^{45}$ Nevertheless, like many professions, that of embalmer claimed to pass down knowledge from one generation to the next, while physicians received an academic education in the House of Life. ${ }^{46}$ Several examples suggest that, even though physicians and embalmers did not receive the same education at the final stage, medical knowledge was also relevant to embalming. ${ }^{47}$

If there is one major difference between the two professions, it is the relationship of each one to the human body. During the Pharaonic period, Egyptian medical knowledge was transmitted through texts that remained unchanged over several generations. ${ }^{48}$ Physicians thus based their prescriptions on established, tried-and-true rules and remedies. In contrast, embalmers had to learn their skills "in the field," studying human and animal anatomy through dissections. Later, during the Greco-Roman period, the two professions merged, resulting in a true scientific advance and the combination of theoretical and practical education. ${ }^{49}$ In light of these considerations, it seems possible to say that, beginning in the Greco-Roman period, the two professions were connected in one way or another. It is reasonable to think that embalmers could also be physicians, even if most of them were not. Conversely, in exceptional cases, a physician could also perform a mummification. Moreover, the use of the word "physician" in the Joseph story may seek to show that Jacob's mummification was not ordinary. Indeed, as Vergote emphasizes, the Hebrew author indicates that Joseph preferred to entrust the task of mummification to physicians, since embalmers, assisted by readers and other aides, would have performed magic and religious rituals that did not conform to the beliefs of the deceased. ${ }^{50}$ This recalls what was mentioned above: The mummification was not performed with a religious aim but instead indicates that Joseph wanted to render a last homage to his father following Egyptian customs. It may have seemed normal to the biblical author to refer to embalming an Egyptian practice par excellence - in an Egyptian funerary context, which allows us to glimpse part of his identity as marked by a life spent in Egypt.

${ }^{44}$ F. JANot, “Embaumeurs/médecins de l'Égypte ancienne," Vesalius 9/1 (2003), 9-12, here 9.

${ }^{45}$ Vergote, Joseph (see n. 1), 198; Fr. JoncKheEre, "Le cadre professionnel et administratif des médecins Égyptiens," ChronEg 26 (1951), 237-268.

${ }^{46}$ JANOT, "Embaumeurs/médecins" (see n. 44), 10.

${ }^{47}$ Ibid., 9; Fr. Jonckheere, Les médecins de l’Égypte pharaonique (Bruxelles: Fondation Egyptologique Reine Elisabeth, 1943), 100-102.

${ }_{48}^{4}$ JANOT, "Embaumeurs/médecins" (see n. 44), 9.

${ }^{49}$ Ibid., 10.

${ }^{50}$ Vergote, Joseph (see n. 1), 199. This seems clear if one assumes, as Vergote does, that the embalmer and the physician had the same basic education in the House of Life and that it was only later that they specialized. They thus would have had a certain degree of shared experience. 


\subsection{The Age of 110 Years}

The Joseph cycle ends with a notice of Joseph's death at the age of 110 years, which may seem insignificant, since Joseph is not the only biblical hero to die at such an advanced age. Indeed, Methuselah lives 969 years, Isaac 180 years, Jacob 147 years, and Moses 120 years, to cite only a few figures. Nevertheless, it is possible to see in the number 110 a reflection of an Egyptian tradition.

Old age was an important topic for the Egyptians, and its consequences are often described in Egyptian texts. Upon first glance, old age was not a sign of prosperity but was instead associated with ugliness and physical weakness. ${ }^{51}$ Yet there are also a variety of passages in which people claim to have lived 110 years or implore the gods to let them live to this age.

This reference to 110 years appears in Egyptian texts such as the narrative of Papyrus Westcar, which goes back to the Twelfth Dynasty. In this narrative, king Cheops learns of the existence of a magician named Djedi who is 110 years old and who "still eats five hundred pieces of bread, half of an ox, and drinks one hundred jugs of beer." 52 One of the most well-known Egyptian texts is the Instruction of Ptahhotep, which states, "The time I spent on the earth is no small thing: I had 110 years of life, which the king gave to me." ${ }^{33}$ Such references occur not only in literature but also in inscriptions on statues or stelae. One such example is the block statue CG $604^{54}$ found at Saqqarah. The inscription found on the back of the statue is a hymn addressed to multiple deities, asking them to allow Khay to rest in his tomb after reaching the age of 110 years. Other important figures also mention the age of 110 years, such as Amenhotep son of Hapu, a royal scribe of Amenhotep III who wrote an autobiography in which he claimed: "I have reached 80 years; through the favors of the king, I will reach 110 years." ${ }^{5}$ At least twenty-seven references to reaching - or wishing to reach - the age of 110 have been collected. Thus, beginning in the Old Kingdom, the concept of an ideal lifespan of 110 was anchored in Egyptian thought. ${ }^{56}$

One could imagine that the biblical author's decision to depict Joseph as dying at the age of 110 is no coincidence. ${ }^{57}$ In concluding the Joseph story, this author wanted to highlight Egyptian customs one last time. Yet the situation seems a bit more complex. Joseph is not the only biblical figure to have reached the age of

\footnotetext{
${ }^{51}$ Montet, La vie (see n. 10), 292.

${ }^{52}$ G. Lefebvre, "L'âge de 110 ans et la vieillesse chez les Égyptiens," CRAIBL (1944), 106-119, here 107.

${ }^{53}$ Ibid., 108.

${ }^{54}$ L. Borchardt, Text und Tafeln zu Nr. 381-603, Vol. 2 of Statuen und Statuetten von Königen und Privatleuten ( ${ }^{\circ}$ 1-1294) (CGC; Berlin: Reichsdruckerei, 1925), 154-155.

${ }^{55}$ Lefebvre, "Lâge de 110 ans" (see n. 52), 109.

${ }^{56}$ J.M.A. JANSSEN, On the Ideal Lifetime of the Egyptians (OMRO 31; Leiden: Rijksmuseum van Oudheden, 1950), 39.

${ }^{57}$ Lefebvre, "Lâge de 110 ans" (see n. 52), 108.
} 
110; Joshua does as well, although his story, unlike that of Joseph, is not connected to Egyptian traditions. Thus, it cannot be ruled out that the reference to the age of 110 in the two passages is purely coincidental. ${ }^{58}$ Nevertheless, I would lean towards understanding the reference to 110 as deliberate, since the text states that Joseph also has himself embalmed.

\section{Lexical Convergences}

\subsection{The Onomasticon}

When Joseph is promoted, the pharaoh gives him an Egyptian name. We know that it was common for foreigners to adopt an Egyptian name when they took up residence in Egypt. The difficulty that often arises from Egyptian texts is that if the narrative does not state a person's place of origin, it is sometimes impossible to deduce whether or not that person is a native Egyptian. ${ }^{59}$ The study of the onomasticon of foreigners in Egyptian sources is thus always a delicate issue. The practice of changing one's name once in Egypt was common both for servants and for important figures in the court. We know, for example, that the foreigner Beniten of Sar Basan, who was the chief butler of Ramesses II and then of Merneptah, bore two Egyptian names: Ramses-m-per-re and Meriunu. ${ }^{60}$

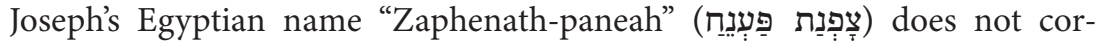
respond to any purely Egyptian name; rather, it seems that the Hebrew author drew on existing onomastic elements to create a new name. Joseph's Egyptian name was inspired by the construction $D d-p 3-n \underline{t} r-i w=f-n h$, meaning "the god said that he will live." This, in turn, is derived from $D d$ - $[\operatorname{god} X]-i w=f$ - $n h$, which is very common in the onomasticon of the Late Period. ${ }^{61}$ Pascal Vernus proposes the following analysis of this construction: ${ }^{62}$

- $D d$ is the verb "so say" in the past tense and is rendered by $צ$ in Hebrew, with the final $d$ in $\underline{d} d$ long having disappeared in the spoken language.

- GodX is the name of a deity and is the subject of the verb $\underline{d} d$.

- $i w=f$ is rendered by the letter $פ$ in Hebrew; it is the prefix of the Future III, third-person singular; the personal pronoun $f$ "he" refers to the child bearing the name.

- ' $n h$ is rendered by the form ענח in Hebrew; in Egyptian, it is the verb "to exist" in the infinitive, occurring after the prefix $i w=f$.

\footnotetext{
${ }^{58}$ B. Couroyer, $R B 66$ (1959), 586. (Review of Vergote, Joseph [see n. 1])

${ }^{59}$ Posener, "Une liste de noms" (see n. 3), 187.

${ }^{60}$ Vergote, Joseph (see n. 1), 141-142.

${ }^{61}$ Y. Volokhine, "L'Égypte et la Bible: histoire et mémoire: À propos de la question de l'Exode et de quelques autres thèmes," BSEG 24/1 (2000), 83-106, here 86.

${ }^{62}$ P. Vernus, Dictionnaire amoureux de l'Égypte pharaonique (Paris: Plon, 2005), 513-516.
} 
This Egyptian name alludes to a frequent practice in Egypt. Due to the high rate of infant mortality, one sought the oracle of a divinity if the newborn survived. In the case of a positive response, one often gave the child a name recalling this oracle, thus permanently associating the individual with the divinity that acted positively on his or her behalf as a child. In pharaonic Egypt, we know that this naming practice always refers to a specific deity, such as $D d-P t h-i w=f-n h$ "Ptahsaid-he-will-live" or $D d-B 3 s t t-i w=f$ - $n h$ "Bastet-said-he-will-live." In contrast, we have no evidence that the expression "The-god-said ..." is used; indeed, if one wanted to attract the good favor of a deity, it seemed logical to invoke the deity explicitly in the child's name. In Genesis, however, the author used this Egyptian naming practice but adapted it to his monotheistic context, replacing the name of the deity with the Egyptian term p3-ntr "the god," rendered by the form פנת in Hebrew (with the final $r$ disappearing). It seems that the Egyptian word $n \underline{t} r$ "god" was used for a particular reason. ${ }^{63}$

Some scholars are opposed to associating Joseph's Egyptian name Zaphenathpaneah with this naming practice in part because, as has already been mentioned, it does not appear with the generic word $n \underline{t} r$ in Egyptian sources, and in part because it is often used for newborns, whereas Joseph receives this name as an adult. It is not difficult, however, to respond to these objections. On the one hand, in Coptic documents reflecting Jewish monotheism, the term $p 3-n t r$ is used in the sense of "God" and not "a god." ${ }^{4}$ Moreover, even if Joseph is an adult when he receives his new name, this is in some sense a rebirth, since Joseph begins a new life in Egypt. It is thus logical that Joseph would receive a new name after this turning point in his life. Besides, a similar situation has already taken place just a few chapters before, in Gen 32:23-32: Joseph's father, Jacob, is renamed "Israel" after wrestling with the angel, indicating that he has been blessed by God.

In the Joseph story, two Egyptian men bear the same name: the man who buys Joseph as a slave at the beginning of the narrative and the man who becomes his father-in-law at the time of his investiture. This name poses a priori less difficulty than that of Joseph, since it could be a Hebraicization of the Egyptian $P_{3}-d i-p 3-R^{c}$ "The one whom Re gives." This name is attested beginning only in the TwentyFirst Dynasty. ${ }^{65}$ We know of four attestations of this name in an Egyptian context: ${ }^{66}$ a stela that can be dated to the Saite period at the earliest ${ }^{67}$ as well as an Aramaic transliteration of the name on an amulet. The last two examples are in Demotic, one dating to the Saite period and the other to the third century вСE.

\footnotetext{
${ }^{63}$ P. Montet, L'Égypte et la Bible (CAB 11; Neuchatel: Delachaux et Niestlé, 1959), 22.

${ }^{64}$ A. R. Schulman, "On the Egyptian name of Joseph: A New Approach SAK 2 (1975), 235243, here 239-241.

${ }^{65}$ Voloknine, "L’Égypte et la Bible" (see n. 61), 86; W. Kosack, Die altägyptischen Personennamen $2.356,123,11$.

${ }^{66}$ Redford, A Study of the Biblical Story of Joseph (see n. 7), 228.

${ }^{67}$ Vergote, Joseph (see n. 1), 147; Cairo JE 65444, see A. Hamada, "Stela of Putiphar," ASAE 39 (1939), 273-277.
} 
People bore the name $P_{3}-d i-R^{\prime}$ beginning in the Eighteenth Dynasty, but it was only in later periods (Saite and Roman) that the form $P_{3}-d i-p_{3}-R$, in which the definite article $p 3$ was added before the name of the god. ${ }^{68}$

It remains to consider the only female Egyptian name in the Joseph story. After the award ceremony for Joseph, the pharaoh gives him a woman named Aseneth as a wife. This name probably echoes an Egyptian name meaning "The-one-belonging-to-Neith" (Ns-N.t). ${ }^{69}$ Many Egyptian proper names are formed by the adjective nsi "belonging to" followed by a divine name. Given that there are no extant attestations of the name Ns-N.t in Egyptian sources, Pierre Montet proposed to see in the final element $ת$ J, like in Joseph's Egyptian name, the word $n t r$, which can be explained by the fact that the final $r$ was no longer pronounced in the New Kingdom. Aseneth would thus be "The-one-belonging-to-God."70

If one allows for a late date of composition or redaction of the Joseph story, the form $N s$ plus the name of a god $(N s-X)$ could very well correspond to an Egyptian reality, since this form occurs frequently beginning in the first millennium BCE. ${ }^{71}$ Even if this form was well-known during the Old Kingdom, it was particularly popular from the end of the New Kingdom down to the Hellenistic period. The transcription of the name in Hebrew likewise reflects a particular stage in the development of the Hebrew language through the addition of a prosthetic aleph, a phenomenon which is attested frequently in Demotic and Greek transcriptions of Egyptian words. ${ }^{72}$ While Vergote proposes the transliteration Iw.s-n-N.t "Shewill-be-dedicated-to-Neith," ${ }^{73}$ others consider that the name Aseneth/Asenath could refer to the Syrian goddess Anat, the sister of Astarte, two deities that are also attested in Egypt. ${ }^{74}$

In light of the study of the Egyptian onomasticon in Genesis 37-50, it seems that the forms that most likely served as models for the narrator are all common to the first millennium вСE. The form of Joseph's Egyptian name ZaphenathPaneah would date to the Late Period. The name Potiphar is attested beginning in the Libyan Period, that is, from 945 BCE. As for Aseneth, the goddess Neith that may be behind the name was particularly popular during the Twenty-Sixth Dynasty (beginning in $664 \mathrm{BCE}$ ), insofar as the kings of this dynasty make Sais, the place of one of Neith's major sanctuaries, their capital. ${ }^{75}$ These Egyptian names used in the Joseph story fit well with the monotheistic nature of the Jewish Diaspora in Egypt. The biblical author refrained from inserting the names

${ }^{68}$ RedFord, A Study of the Biblical Story of Joseph (see n. 7), 228-229.

${ }^{69}$ Vernus, Dictionnaire (see n. 62), 513.

${ }^{70}$ Montet, L'Égypte et la Bible (see n. 63), 22.

${ }^{71}$ A. R. Schulman, "On the Egyptian name" (see n. 64), 238-239.

${ }^{72}$ Redford, A Study of the Biblical Story of Joseph (see n. 7), 229.

${ }^{73}$ Vergote, Joseph (see n. 1), 149-150.

${ }^{74} \mathrm{~A}$. Zivie, La prison de Joseph: L'Égypte des pharaons et le monde de la Bible (Paris: Bayard, 2004), 59.

${ }^{75}$ Vernus, Dictionnaire (see n. 62), 514. 
of specific Egyptian deities into these names in order not to pose a stumbling block to his readers.

\section{2 "The Land of the Hebrews"}

In Genesis 40, when Joseph finds himself in prison with the chief baker and cupbearer, he tells the latter how he found himself in Egypt, stating that he was taken from the "land of the Hebrews." This expression seems incoherent with the broader context of the ancestral narratives in Genesis. Apart from historical and archaeological considerations, the Hebrews were not a dominant element in the Palestinian population, even if one accepts a broader meaning of the term "Hebrew." In what period did the expression "land of the Hebrews" have a clear and logical meaning both for Israel and for Egypt?"76

There are no references to Palestine as the "land of the Hebrews" either in texts from the New Kingdom or in texts dating to the Israelite monarchy. There are other designations, however, for the regions neighboring Egypt. For example, $\operatorname{t} n w^{77}$ and $3 m^{78}$ are two archaic names designating Palestine and Syria. Later, beginning in the Eighteenth Dynasty, the term $G_{3} b y^{79}$ referred to Palestine and Lebanon, and during the Greco-Roman period, the term $\mathrm{H}_{3} \mathrm{rw}^{80}$ was used for the same. Egyptian texts sometimes speak of $\mathrm{Kn}^{n} n,{ }^{81}$ which refers to the lands between Gaza and the Orontes, as well as Prst ${ }^{82}$ during the Twenty-Second Dynasty.

Thanks to the Demotic Papyrus Vienna, which deals with a lunar eclipse, it is possible to learn a bit more about the expression that interests us here. The Demotic in this papyrus can be dated on linguistic grounds to the Twenty-Sixth Dynasty. In this narrative, each omen is connected to the future event that is predicted to occur, thereby also indicating the country that will be affected. This omen literature originated in Babylon and is attested in Egypt no earlier than the Saite period, that is, during the Late Period. Although the text itself dates to the Roman period, the political situation that it describes as well as the reference to a "king of Egypt" indicate that it depicts a scene that is characteristic of the Saite period. In addition to Egypt, four countries are mentioned: Assyria, Amurru, Crete, and finally ' $y b r$ "the land of the Hebrews." Within this list, the names refer to lands and not to ethnic groups in the vicinity of Egypt. Thus, here ' $y b r$ does

\footnotetext{
${ }^{76}$ D. B. Redford, “The 'Land of the Hebrews' in Gen. XL 15," VT 15/4 (1965), 529-532.

${ }^{77}$ H. Gauthier, Dictionnaire des noms géographiques contenus dans les textes hiéroglyphiques I-VII (Cairo: Imprimerie de l'Institut français d'archéologie orientale pour la Société royale de géographie d'Egypte, 1925-1931), here 3.141.

${ }^{78}$ Ibid., 1.133 .

79 Ibid., 4.108 .

${ }^{80}$ Ibid., 4.151 .

${ }^{81}$ Ibid., 5.187.

82 Ibid., 1.144.
} 
not have to do with the Hebrews as a people but with the place where they live. It is thus possible to concluded that, at least beginning in the Saite period (ca. $664 \mathrm{BCE}$ ), the gentilic "Hebrew" could refer to Palestine as geographical entity and was familiar to the Egyptians as such. This seems to be a further indication of the late date of the Joseph story.

\subsection{The harạtummîm}

The interpretation of dreams was an important activity in Egypt; if a dream was not understood by the dreamer, it had to be deciphered. In Genesis 41, the pharaoh has two dreams, and since he does not understand them, he calls on the priests and sages to explain them, but no one is able to do so. In the Hebrew text, the "priests" are referred to as hartummîm. For decades, researchers have argued that this is a foreign loanword in Hebrew.

Many theories were proposed before a satisfactory solution was found.$^{83}$ The term hartom in the singular (חרטטם) corresponds to the second element in the Egyptian title $h r y$ - $h b$ hry-tp "chief lector priest." ${ }^{84}$ This long title was abbreviated early on into hry-tp; over time it shifted to hry-tb and then to hry-tm, and it is in this last form that the word entered the biblical text. ${ }^{85}$ The shift from hry-tp to $h r y$ - $t b$ would have taken place during the pre-Demotic period; ${ }^{86}$ thus, the point at which the expression entered the Bible cannot be earlier than the seventh or sixth century вСЕ. The word's origin can be confirmed by comparing its usage in Egyptian texts and in the biblical text.

Given the importance of dream interpretation in Egypt, the existence of a class of professional dream interpreters seems obvious. The harțummim whom the pharaoh consults in Genesis 41 thus would have been part of an Egyptian institution. ${ }^{87}$ Moreover, when the Bible was translated into Coptic, the expression used to refer to dream interpreters in the Joseph story was sphranš, reflecting the title $s \check{s}$ pr-'nh "scribe of the House of Life." 88 We know that one of the positions

${ }^{83}$ A. ERMAN, Die Religion der Ägypter: ihr Werden und Vergehen in vier Jahrtausenden (Berlin: Walter de Gruyter, 1934), 308; A.S. YAHUdA, Die Sprache des Pentateuch in ihren Beziehungen zum Ägyptischen I (Berlin: Walter de Gruyter, 1929), 88; H. Goedicke, "Harțummîm," Or 65 (1996), 24-30.

${ }^{84}$ Vergote, Joseph (see n. 1), 67.

${ }^{85}$ J. Quaegebeur, "On the Egyptian Equivalent of Biblical Harțummîm," in Pharaonic Egypt: The Bible and Christianity (ed. S. I. Groll; Jérusalem: Magnes Press, 1983), 162-172.

${ }^{86}$ ReDFord, A Study of the Biblical Story of Joseph (see n. 7), 203-204.

${ }^{87}$ N. SHupak, "A Fresh Look at the Dreams of the Officials and of Pharaoh in the Story of Joseph (Genesis 40-41) in the Light of Egyptian Dreams," JANES 30 (2006), 103-138, here 134-135.

${ }^{88}$ S. SAUneron, "Les songes et leur interprétation dans l’ancienne Égypte," in Les songes et leur interprétation (ed. S. Sauneron; SOr 2; Paris: Seuil, 1959), 17-61, here 39; Vergote, Joseph (see n. 1), 74 . 
within the House of Life was that of lector priest, since in many texts references to hry-tp are accompanied by references to the House of Life.

The House of Life was similar to a school; there, the students first learned to read and write based on classic texts, and the most gifted could pursue a career as a scribe. ${ }^{89}$ The hartummîm are mentioned in various Egyptian as well as biblical texts. Most of the time, this term appears in the Bible in narratives relating to Egypt, such as in the exodus narrative, when the harțmmim are in competition with Moses and Aaron (Exod 7:11). The only case in which the term does not appear in an Egyptian context is in the book of Daniel, although there it describes a person in the Babylonian court who performs the same functions. In these passages, the harțmmîm have two main qualities: the ability to interpret dreams and the ability to perform magic and sorcery. ${ }^{90}$ This corresponds to what we find in Egyptian sources. For example, Papyrus Westcar refers to two "chief lector priests" named Ubaone and Djajaemonkh. We also know of actual lector priests, such as Amenhotep son of Hapu.

If one looks for information on the hry-tp as interpreters of dreams, it is during the Hellenistic period that the most evidence is found. Indeed, it is beginning in this period that incubations were most frequently practiced. ${ }^{91}$ The people came to the temples with the expectation of having a dream in which a god would speak to them. Each temple thus had interpreters on hand to explain the dreams that occurred within the sacred space..$^{92}$ In this respect, the hartummîm in the biblical text reflect an Egyptian reality. In Egypt, the practice of interpreting obscure dreams was quite common, since such dreams were a central concern of the population. The central aspect in the Joseph story is that the hartummim serving in the pharaoh's court are unable to explain his dreams to him, which allows Joseph to intervene. The knowledge of the hartummîm and that of Joseph is of different origin: While the harțmmîm acquired their knowledge through studying in the House of Life, Joseph is divinely gifted, which places him above the Egyptian harțmmim in the biblical narrative. ${ }^{93}$ In Gen 41:39, the pharaoh tells Joseph: "Since God has shown you all this, there is no one so discerning and wise as you."

\footnotetext{
${ }^{89}$ C. Leblanc, "Lécole du temple (ât-sebaï) et le per-ânkh (maison de vie), à propos de récentes découvertes effectuées dans le contexte du Ramesseum," in Actes du 9ème Congrès international des Égyptologues vol. II, Grenoble, 6-12 septembre 2004 (ed. J-C. Goyon and C. Gardin; OLA 150; Leuven: Peeters, 2007), 1101-1108, here 1105.

${ }^{90}$ SHupaK, "A Fresh Look" (see n. 87), 135.

${ }^{91}$ Ibid., 136.

92 S. Sauneron, "Maison de Vie," in Dictionnaire de la civilisation égyptienne (ed. G. Posener et al; Paris: F. Hazan, 1970), 159-160.

${ }^{93}$ ShupaK, "A Fresh Look" (see n. 87), 137.
} 


\section{Conclusion}

The Egyptian elements in the biblical story of Joseph help us to date the narrative more precisely and provide us with some further information about its historical context. The Egyptological evidence seems to correspond to Egypt during the Persian or even Hellenistic period. We know that the narrative must have originally existed independently and that different layers can be identified that may thus correspond to different periods in Egyptian history. We thus propose the following model: Starting with an original core, the Jewish Diaspora of the Persian period was responsible for the first Egyptian elements in the text, incorporating elements from contemporary daily life as well as older traditions in order to give more plausibility to the narrative. Given that certain elements in the story are characteristic of the Hellenistic period alone, it is possible to imagine that the new Diaspora during the Ptolemaic period wanted to appropriate the text and thus added elements that characterized its own historical context. Finally, it should be noted that some chapters of the Joseph story do not contain Egyptian elements at all. These passages may have belonged to the original narrative but may also be part of the redaction that incorporated the Joseph story into the Pentateuch, allowing the story to serve as the continuation of the Jacob cycle and to lead into the exodus narrative. Although this model remains hypothetical, it fits well with the notion of a larger redaction, since we know that certain parts of the text (both individual verses and entire chapters) were written at different points in time.

The Joseph story seems to have been adapted to the actual political and cultural conditions that characterized life in the Jewish Diaspora during that time. For example, in using Egyptian-sounding names, the text's author wanted to give the story a strong Egyptian coloring. As a result, Jews in the Diaspora must have identified with the figure of Joseph, since they too were surrounded by people bearing Egyptian names. It thus seems fair to label the Joseph story as a "Diaspora novella." This genre reflects the preoccupations and experiences of the Jewish community in Egypt. As Thomas Römer has rightly observed, "the main aim of this story would have been to show Diaspora Jews that their future lay in the country that received them and that they had every chance to prosper and to achieve positions of influence if only they would trust in divine providence and their own initiative." ${ }^{.4}$ Joseph is the perfect prototype of the person who succeeds in one's "new life" even though everything began very badly for him, a situation that some Diaspora Jews may have found themselves in.

\footnotetext{
${ }^{94}$ T. Römer, "Le cycle de Joseph: Sources, corpus, unité," FoiVie 86 (1987), 3-15, here 5 ("le but principal de ce récit aurait été de montrer aux Juifs de la diaspora que leur avenir se situait bien dans leur pays d'accueil et qu'ils avaient donc toutes les chances de prospérer et d'acquérir des positions influentes pour peu qu'ils fassent confiance à la providence divine et à leur propre initiative").
} 
Unfortunately, I was not able to deal with all of the Egyptian elements in the Joseph story here; other aspects have already been studied by other scholars (such as the different functions of characters such as the baker, cupbearer, eunuch, and the spies; the interpretation of Joseph's and Pharaoh's dreams; the genre of the Königsnovelle; the comparison with the Tale of the Two Brothers and the Tale of Sinuhe; and the lexical convergences with Egyptian texts), and these likewise tend to confirm a late date of composition and redaction of the Joseph story. 



\title{
Joseph in Egypt
}

\section{A Critical Evaluation of the Classical Parallels and a New Interpretation}

\author{
Bernd U. Schipper
}

The Egyptian background of the Joseph story has been fascinating scholars for decades. Less than twenty years after Jean-François Champollion had deciphered hieroglyphs in 1822, Old Testament scholar Ernst Wilhelm Hengstenberg published a book with the title, Die Bücher Moses' und Ägypten. The book was published four years later as Egypt and the Books of Moses, or, the Books of Moses Illustrated by the Monuments of Egypt. ${ }^{1}$ The subtitle expresses Hengstenberg's interests. He wanted to use new insights into ancient Egypt to study the historical background of the pentateuchal narratives, including the Joseph story. ${ }^{2}$ Because of Hengstenberg's pietistic background - he was close to the so-called Erweckungsbewegung ("revivalism-movement"), ${ }^{3}$ his primary intention was to demonstrate that the books of Moses contain historical information that could document the historical reliability of the Bible. ${ }^{4}$ This approach continues in the more recent work of scholars who use their knowledge of Egypt to date the Joseph story to the late second millennium всE. Given that in the sequence of the biblical events the Joseph story comes before the Exodus story, the text was placed in the Egyptian "New Kingdom," in the Ramesside era (1292-1069 вСE).

\footnotetext{
${ }^{1}$ An English edition was first published in 1845; the full title of the German edition is E.W. Hengstenberg, Die Bücher Moses' und Ägypten nebst einer Beilage: Manetho und die Hyksos (Berlin: Oehmigke, 1841).

${ }^{2}$ See IDEM, Egypt and the Books of Moses, or, the Books of Moses Illustrated by the Monuments of Egypt (Andover: Allen, Morill, and Wardell, 1843), 23-77.

${ }^{3}$ See M.A. Deuschle, Ernst Wilhelm Hengstenberg: Ein Beitrag zur Erforschung des kirchlichen Konservativismus im Preußen des 19. Jahrhunderts (BHT 169; Tübingen: Mohr Siebeck, 2013), 51-97.

${ }^{4}$ See for example his 1836/1839 published book: E. W. Hengstenberg, Die Authentie des Pentateuches: Erwiesen von Ernst Wilhelm Hengstenberg, Vols. 2 and 3 of Beiträge zur Einleitung in das Alte Testament (Berlin: Oehmigke, 1836), LIX: "Keiner der Gegner der Ächtheit des Pent. hat sich bis jetzt die Mühe gegeben, sich gründlich mit den Resultaten der neueren Forschung über Ägypten zu beschäftigen."
} 
Thus, scholars such as Joseph Vergote, Kenneth A. Kitchen, and James Hoffmeier searched for Egyptian parallels from the Ramesside dynasty. ${ }^{5}$

In 1970, the Egyptologist Donald B. Redford presented a different approach. In a groundbreaking study, Redford pointed to the simple fact that when examining the text with the eyes of an Egyptologist, "the writer was not so well acquainted with Egypt as has often been imagined."' Furthermore, the specific so-called "Egyptian" motifs do not point to the New Kingdom but to the Late Period of Egypt, the historical period from the Twenty-Sixth Dynasty onwards - in absolute chronology, from the middle of the seventh century to the late fifth and fourth century BCE. In contrast to this position, Erhard Blum and Kristin Weingart recently argued that the Joseph story displays significant similarities with the Egyptian story of Sinuhe. This is the reason why Blum and Weingart date the oldest literary layer of the Joseph story to the eighth century BCE. ${ }^{7}$ Other scholars see close similarities between Gen 39 (Joseph and Potiphera's wife) and the Egyptian Tale of the Two Brothers and date the Joseph story back to the early monarchic period of Ancient Israel. ${ }^{8}$

The present article will pursue a different perspective. I will start with a brief overview of the so-called Joseph story, highlighting the main characteristics of the text. After that I discuss the classic parallels such as the Sinuhe narrative and the Tale of the Two Brothers, and finally I will present a new thesis on the possible socio-historical background of the Joseph story.

\section{The Joseph Story ${ }^{9}$}

The Joseph story in Gen 37-50 is carefully structured. Gen 37 presents the exposition of the story, mentioning the dreams of Joseph, the reaction of his brothers, and the sale of Joseph to traders. Gen 39-41 report on Joseph's life in Egypt, Gen 42-45 tell of the journey of Joseph's brothers to Egypt due to a famine, Gen 46-49 narrate the journey of Jacob to Egypt, and in Gen 50 Jacob dies and the whole sequence of events is summarized by a theological résumé.

${ }^{5}$ J. Vergote, Joseph en Égypte: Genèse chap. 37-50 à la lumière des études égyptologiques récentes (OBL 3; Leuven: Peeters, 1959); IDEM, "Joseph en Égypte: 25 ans après," in Pharaonic Egypt: The Bible and Christianity (ed. S. Israelit-Groll; Jerusalem: Magnes Press, 1985), 289306; and K.A. Kitchen, On the Reliability of the Old Testament (Grand Rapids, MI: Eerdmans, 2003), 261-270.

${ }^{6}$ D. B. Redford, A Study of the Biblical Story of Joseph (Genesis 37-50) (VTSup 20; Leiden: Brill, 1970), 241-242.

${ }^{7}$ E. Blum and K. Weingart, "The Joseph Story: Diaspora Novella or North-Israelite Narrative ?", ZAW 129/4 (2017), 501-521, here 520.

${ }^{8}$ S. Tower-Hollis, The Ancient Egyptian "Tale of Two Brothers" (2nd ed.; Oakville, ON: Bannerstone Press, 2008).

${ }^{9}$ For the following see also B. U. Schipper, "Joseph, Ahiqar, and Elephantine: The Joseph Story as Diaspora Novella," Journal of Ancient Egyptian Interconnections 18 (2018), 71-84. 
It was Hermann Gunkel who first called the Joseph story a "novella" on the basis of its unique literary structure. ${ }^{10}$ Other scholars followed Gunkel, among them Gerhard von Rad, who famously described the Joseph story as "a novella through and through." 11 Gerhard von Rad's interpretation of the Joseph story is to some extent paradigmatic, since it illustrates a dilemma. On the one hand, von Rad emphasized the literary character of the text as a literary masterpiece, being well-composed with a clear storyline. On the other hand, being trained in the approach of the classical Documentary Hypothesis, von Rad tried to separate different literary sources in the Joseph story. ${ }^{12}$ In an article from 1968, R. Norman Whybray summarized:

The new approach to the Joseph story which has been pioneered in the writings of Gerhard von Rad suggests, however, that a re-examination of the question of sources is needed. ${ }^{13}$

This statement by Whybray is literally the tip of an iceberg. Since the late 1960s, a number of disparate studies on the composition of the Joseph story have been published. Some scholars continued to postulate different literary sources in the story, ${ }^{14}$ while others argued that the Joseph story should be taken as a stand-alone unit - a piece of literature which is foreign to the Documentary Hypothesis. ${ }^{15}$

Since it is not the purpose of this article to discuss the various literary theories for the Joseph story, let me briefly summarize my own assumptions in four points:

1) The Joseph story (Gen 37-50) should be understood as a stand-alone piece of literature despite the fact that it allegedly serves as a bridge between the ancestral narratives and the exodus story. In fact, on a literary level, this bridge is extremely weak. ${ }^{16}$ The thematic links that do exist between the Joseph story and the ancestral narratives in Gen 12-36 also reveal a number of differences. ${ }^{17}$

\footnotetext{
${ }^{10}$ H. Gunkel, Genesis (3rd ed.; HKAT I/1; Göttingen: Vandenhoeck \& Ruprecht, 1910), 397.

${ }^{11}$ G. von Rad, "The Joseph Narrative and Ancient Wisdom," in The Problem of the Hexateuch and Other Essays (New York: McGraw-Hill, 1966), 292-300, here 292.

${ }^{12}$ G. von RAD, Das erste Buch Mose: Genesis (9th ed.; ATD 2/4; Göttingen: Vandenhoeck \& Ruprecht, 1972), 284. See for the classical approach of the Documentary Hypothesis on the Joseph story J. Wellhausen, Die Composition des Hexateuchs und der historischen Bücher des Alten Testaments (3rd ed.; Berlin: Reimer, 1899), 52.

${ }^{13}$ R. N. Whybray, “The Joseph Story and Pentateuchal Criticism," VT 18 (1968), 522-528, here 523 .

${ }^{14}$ See the overview in H.-C. Schmitт, "Die Hintergründe der 'neuesten Pentateuchkritik' und der literarische Befund der Josefsgeschichte Gen 37-50," ZAW 97/2 (1985), 161-179.

${ }^{15}$ So, for example, R. G. Kratz, The Composition of the Narrative Books of the Old Testament (London: T\&T Clark, 2005), 275: "The documentary theory is not applicable to the Joseph story."

${ }^{16}$ See K. Schmid, Genesis and the Moses story: Israel's Dual Origins in the Hebrew Bible (Siphrut: Literature and Theology of the Hebrew Scriptures 3; Winona Lake, IN: Eisenbrauns, 2010), 52.

17 Ibid., 4-6.
} 
Moreover, in Exod 1:6-8 the memory of the Joseph story must be wiped out before the narrative of the exodus can begin. Therefore, one should not take the Joseph story, or even a part of it (Gen 37-45), as an appendix to the ancestral history, as Reinhard G. Kratz and most recently Franziska Ede have argued. ${ }^{18}$ Rather, it is an independent piece of literature which was written against the backdrop of the narratives of the patriarchs and then integrated into its present literary context on a redactional level. ${ }^{19}$

2) Three literary hands can be distinguished as operating in the redactional levels within Gen 37-50: (1) the Priestly redactor, often called the "Priestly Grundschrift" of the Pentateuch, (2) the non-priestly narrative, which contains most of what one calls the "Joseph story," and (3) a number of literary additions, most of them in Gen 46-50 (Gen 46: ${ }^{\star} 1-5,48$ [+ 41:50-52]; 49; 50:22-26). ${ }^{20}$ Since the Priestly stratum in Gen $37-50$ is very small, the term "Joseph story" refers to the non-priestly layer. ${ }^{21}$

3) In a groundbreaking study from 1976, Herbert Donner convincingly showed that the Joseph story (i.e., the non-priestly literary layer) is structured by doublets ("Doppelungen"): This includes Joseph's two dreams regarding his brothers, the two dreams of the court officials, and two dreams of the Pharaoh. Joseph is incarcerated twice, first in the pit, then in jail; the brothers travel twice to Egypt; etc. ${ }^{22}$ In a nutshell, the literary evidence used by previous (and also current) research for distinguishing different literary sources within the Joseph story turns out to be a compositional strategy of the author. ${ }^{23} \mathrm{Or}$, to put this in terms of classical pentateuchal criticism, it is impossible to differentiate between two different literary sources such as a "Yahwist" or an "Elohist" within the non-priestly literary layer of the Joseph story. ${ }^{24}$

\footnotetext{
${ }^{18}$ Kratz, The Composition of the Narrative Books of the Old Testament (see n. 15), 275276. See also F. EDE, Die Josefsgeschichte: Literarkritische und redaktionsgeschichtliche Untersuchungen von Gen 37-50 (BZAW 485; Berlin and Boston: Walter de Gruyter, 2016).

${ }^{19}$ See B. U. Schipper, "Gen 37-50 and the Model of a Gradual Extension: A Response to David M. Carr and Franziska Ede," in Book-Seams in the Hexateuch I: The Literary Transitions between the Books of Genesis/Exodus and Joshua/Judges (ed. C. Berner and H. Samuel; FAT 120; Tübingen: Mohr Siebeck, 2018), 121-135.

${ }^{20}$ See E. Blum, Die Komposition der Vätergeschichte (WMANT 57; Neukirchen-Vluyn: Neukirchener Verlag, 1984), 255-256.

${ }^{21}$ It is an important question whether or not the Priestly redactor knew the non-priestly Joseph story. Can the non-priestly text be assigned to a post-priestly stage of composition? See T. Römer, “The Joseph story in the Book of Genesis: Pre-P or Post-P?", in The Post-Priestly Pentateuch: New Perspectives on Its Redactional Development and Theological Profiles (ed. F. Giuntoli and K. Schmid; FAT 101; Tübingen: Mohr Siebeck, 2015), 185-202.

${ }^{22}$ H. Donner, Die literarische Gestalt der alttestamentlichen Josephsgeschichte (SHAW.PH 2; Heidelberg: Universitätsverlag Winter, 1976), 36-37.

${ }^{23}$ In contrast, J.S. BADEN, The Composition of the Pentateuch: Renewing the Documentary Hypothesis (ABRL; New Haven, CT: Yale University Press, 2012), 34 takes "Midianites and Ishmaelites" in Gen 37 as a point of departure for literary source criticism.

${ }^{24}$ See n. 13 above. This can also be seen in A. Graupner, Der Elohist: Gegenwart und
} 
4) This "Joseph story" of Gen $37,39-47$, and $50^{25}$ appears to be a masterful composition that is structured by different motifs. The Joseph story is, in the words of Konrad Schmid, "a self-contained, meaningfully planned novella."26 It is a piece of literature with affinities to the world of wisdom but also with a theological profile that differs strongly from that of many other biblical books, including the so-called "Deuteronomistic History."27

Let me explain the last point by highlighting a few aspects of the composition, while presenting my own interpretation of the Joseph story.

The main compositional principle can already be found in Gen 37. With Jacob's love for Joseph and his brothers' hatred of him, the foundations are laid for the following events. ${ }^{28}$ Joseph has two dreams and shares them, strangely enough, with his brothers and his father. The reader of the text expects something to happen, and this is exactly what is reported a few verses later in Gen 37.

The brothers have gone to pasture their father's flock (v. 12). Jacob sends Joseph to them (v. 13), and when the brothers see him from a distance, they plot to put him to death. In Gen 37:20 the brothers say:

"Now then, come and let us kill him and throw him into one of the pits; and we will say: 'A wild beast devoured him.' Then let us see what will become of his dreams."

Precisely this question becomes the crucial question driving the storyline: What will become of Joseph's dreams? Will they come true? Dreams mark important turning points in the fall and rise of Joseph..$^{29}$ While Joseph's dreams involving his brothers initially get him in trouble, his ability to explain the dreams of Egyptians

Wirksamkeit des transzendenten Gottes in der Geschichte (WMANT 97; Neukirchen-Vluyn: Neukirchener Verlag, 2002), who cannot provide new arguments against the old critique of W. Rudolf from 1933: "Die Josephsgeschichte," in Der Elohist als Erzähler, ein Irrweg der Pentateuchkritik?: An der Genesis erläutert (ed. P. Volz and W. Rudolf; BZAW 63; Giessen: Alfred Töpelmann, 1933), 143-183.

${ }^{25}$ The present article is not the place to discuss possible redactional additions to the nonpriestly Joseph story.

${ }^{26}$ Schmid, Genesis and the Moses Story (see n. 16), 51. See also G. W. Coats, From Canaan to Egypt: Structural and Theological Context for the Joseph Story (CBQMS 4; Washington, DC: Catholic Biblical Association of America, 1976).

${ }^{27}$ This can be seen, for example, in the Joseph story's positive presentation and evaluation of kingship, which contrasts with the highly critical view of the Deuteronomistic History; see F. Crüsemannn, Widerstand gegen das Königtum: Die antiköniglichen Texte des Alten Testaments und der Kampf um den frühen israelitischen Staat (WMANT 49; Neukirchen-Vluyn: Neukirchener Verlag, 1978), 174-180.

${ }^{28}$ See H. Seebass, Genesis III: Josephsgeschichte $(37,1-50,26)$ (Neukirchen-Vluyn: Neukirchener Verlag, 2000), 20-24 and 28-29.

${ }^{29}$ For this see the overview in K. Schmid, "Die Josephsgeschichte im Pentateuch," in $A b$ schied vom Jahwisten: Die Komposition des Hexateuch in der jüngsten Diskussion (ed. J. C. Gertz et al.; BZAW 315; Berlin: Walter de Gruyter, 2002), 83-118, here 95-98. 
(first the two prisoners, then Pharaoh) secure his release from jail and propel him to second-in-command over Egypt. ${ }^{30}$

This motif is further elaborated by the theme of dreams coming true. ${ }^{31}$ The dreams of the two prisoners (the baker and the cupbearer) come true as well as those of Pharaoh. And finally, when looking at the end of the story in Gen 50 it turns out that Joseph's first dream is realized as well.

After Jacob's death in Gen 50, the brothers are afraid that Joseph will exact revenge. They come to Joseph, fall down before him, and say, "Behold, we are your servants" (v. 18). Thus, the brothers' question expressed in the phrase "Then let us see what will become of his dreams!" (Gen 37:20) is finally answered: They will all come true.

This motif is complemented by another aspect. In Gen 50:19-20 Joseph answers his brothers:

(19) "Do not be afraid, for am I in God's place? (20) And as for you, you meant evil against me, but God meant it for good in order to bring about this present result, to preserve many people alive."

The famous words from the end of the Joseph story - "You meant evil against me, but God meant it for good" - shed light on the sequence of events. Everything happens for a reason; it all has a deeper sense, although this deeper meaning is not apparent in the situation itself. ${ }^{32}$

This message is illustrated in the Joseph story by a literary style in which a decisive turn of events takes place at key junctures. When everything seems to be lost, somebody shows up and the story moves on. So, for example, when the brothers put Joseph in the pit (in Gen 37), some traders pass by. They lift Joseph out of the pit and sell him to still other men who then bring him to Egypt. In Egypt, while sitting in prison Joseph meets the two Egyptians having a dream and so on. There can be no doubt that one of the main characteristics of the Joseph story is the frequency of these turns in the plot, turns which are explained in the end when it becomes clear that all of the characters' changes in fortune were caused by a higher power - God. ${ }^{33}$

This corresponds well with another characteristic of the story. In most parts of Gen $37-50$, God is not explicitly mentioned ${ }^{34}$ but instead acts behind the scenes. When God is mentioned, such as in Gen 39 , he does not act directly but rather

\footnotetext{
${ }^{30}$ J. LancKau, Der Herr der Träume: Eine Studie zur Funktion des Traumes in der Josefsgeschichte (ATANT 85; Zürich: TVZ, 2006).

${ }^{31}$ See Schmid, "Die Josephsgeschichte im Pentateuch" (see n. 29), 96 and J. Евасн, Genesis 37-50 (HTKAT; Freiburg: Herder, 2007), 40-41.

32 von RAD, Das erste Buch Mose (see n. 12), 355-356.

${ }^{33}$ See Евасн, Genesis 37-50 (see n. 31), 40 who speaks of a providentia dei.

${ }^{34}$ This is the case already in the introduction of the Joseph story in Genesis 37, where "the divine name makes no appearance." See BADEN, The Composition of the Pentateuch (see n. 23), 34 .
} 
lays the foundation for the protagonist's own actions. So, for example, in Gen 39:21, God grants Joseph favor in the sight of the prison warden. This divine act is complemented by Joseph, who gets out of prison by using one of his main skills: interpreting the dreams of the two prisoners, which ultimately brings him from prison up to the royal court of Egypt.

It has often been observed that this type of divine action refers to a certain theological concept. When Joseph says in Gen 50:19, "Am I in God's place?" he refers to God as the one who judges. The Joseph novella is shaped by a theology that can best be called "theocratic." This theocratic theology shares some similarities with the Chronicler's History, and it stands in contrast to the Deuteronomistic History. ${ }^{35}$ Furthermore, the theocratic framing of the Joseph story is also the reason why it cannot be called a "didactic wisdom story" ("eine weisheitliche Lehrerzählung," Gerhard von Rad). ${ }^{36}$ Since the beginning of scholarly investigation on the Joseph story, scholars have highlighted the sapiential coloring of the text. ${ }^{37}$ One reason is the characterization of Joseph in Gen 39, where he acts like a good wisdom student who rejects the offers from the seductive woman. ${ }^{38}$ When Joseph explains the dreams of the seven fat cows and the seven wretched and lean cows coming out of the Nile to Pharaoh, he concludes with the words: "And now let Pharaoh look for a man discerning and wise, and set him over the land of Egypt" (Gen 41:33).

Joseph not only tells Pharaoh what to do, but he also advises him to look for a man "discerning and wise" (נָבוֹן וְָָכָָם Gen 41:33). This very statement is taken up by the Pharaoh, who concludes (v. 39): "There is no one so discerning and

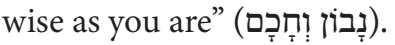

Joseph is the wise man Pharaoh needs, and Joseph makes this as explicit as possible. He tells Pharaoh what to do, knowing that all of the other dream-specialists failed and that he is the only person who appears נָבוֹן וְחָָָם "discerning and wise." This is complemented in Gen 41:38 by Pharaoh's statement that Joseph

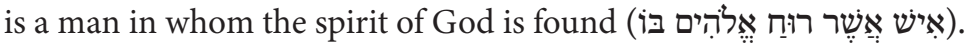

Upon first glance, Joseph appears to be a wise man, and Gerhard von Rad goes so far as to declare him a role model. But this is only one side of the coin. "Wisdom literature," as Michael Fox points out, "recognizes that the wise and right-

\footnotetext{
${ }^{35}$ Schmid, "Die Josephsgeschichte im Pentateuch" (see n. 29), 113.

${ }^{36}$ von RAD, "The Joseph Narrative and Ancient Wisdom" (see n. 11), 300. For a fundamental critique of Gerhard von Rad's position see REDFORD, A Study of the Biblical Story of Joseph (see n. 6), 103-105 who argues that Joseph does not fit the wisdom ideal of the "long suffering, silent, modest man of who controls his spirit" (104).

${ }^{37}$ For a detailed "sapiential" reading of the Joseph story see von RAD, "The Joseph Narrative and Ancient Wisdom" (see n. 11), 293-298 and the overview in R. Lux, "Josef/Josefsgeschichte," in Das wissenschaftliche Bibellexikon im Internet (ed. M. Bauks and K. Koenen, January 2013), https://www.bibelwissenschaft.de/de/stichwort/22800/. Accessed 11/28/19.

${ }^{38}$ See section 2 below.
} 
eous might find themselves in hard times despite their virtues." ${ }^{39}$ In the Joseph story, this sapiential principle is combined with the aforementioned theocratic theology. Joseph acts to some extent according to the principles of wisdom, but this is correlated with the insight that God's help is also necessary. What we have in the Joseph story is a highly developed notion of wisdom, a wisdom grounded on piety and on an insight found in Prov 16:9: "The heart of man plans his way,

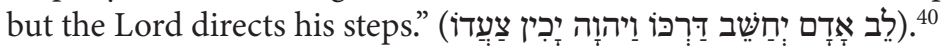

Three points can be summarized from the argument so far:

1) The Joseph story is a masterful composition that, due to its literary style, is best categorized as a "novella."

2) Joseph's fall and rise is told by a sequence of events that is driven by one main motif: dreams. Joseph's dreams about his brothers in Gen 37 mark the starting point for all the trouble. His ability to interpret dreams elevates him from prison to the royal court. Precisely this skill makes him one of the most powerful men in Egypt, second only to the Pharaoh.

3) All of this is reported in a style in which God acts, so to speak, "behind the scenes" - from which it ultimately turns out that God was the power behind the journey of life. On the one hand, God creates the basis for the sequence of events, while on the other hand, the main turns of fortune are brought about by Joseph himself, who uses his practical skills and his judiciousness. ${ }^{41}$

In the following I will demonstrate that this characterization of Joseph, his practical skills, and his judiciousness, brings the Joseph story close to the Aramaic Wisdom composition on the wise Ahiqar. But before doing this, it is necessary to discuss the classical positions on the Egyptian background of the Joseph story.

\section{The Egyptian Background of the Joseph Story}

Previous research already recognized that a number of individual motifs in the Joseph story do not point to New Kingdom Egypt but to the Late Period, that is, the time from the seventh-fourth centuries BCE. This is true for the names and also for the investiture of Joseph. The description in Gen 41:42 relates to material from the Egyptian Twenty-Sixth Dynasty (669-525 вСЕ). ${ }^{42}$

\footnotetext{
${ }^{39}$ M. V. Fox, "Wisdom in the Joseph Story," VT 51/1 (2001), 26-41, here 31. See also Prov 24:16: "For a righteous man falls seven times, and rises again, but the wicked stumble in time of

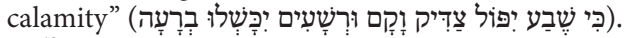

${ }^{40}$ See also Prov 19:21: "Many designs are in a man's heart, but it is the Lord's plan that comes

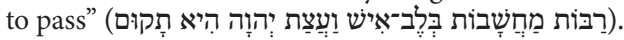

${ }^{41}$ Fox, "Wisdom in the Joseph story" (see n. 39), 31-33.

${ }^{42}$ See B. U. SCHIPper, "Gen 41:42 and the Egyptian Background to the Investiture of Joseph," $R B$ 118/3 (2011), 331-338.
} 
When appointed as royal vizier in Gen 41, Joseph receives the Egyptian name

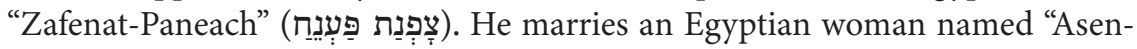

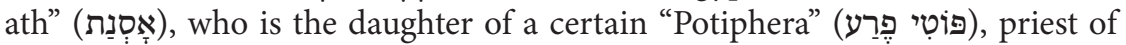
On. Interestingly, these are the only Egyptian names in the story. ${ }^{43}$ Neither the Pharaoh, Potiphera's wife, nor the two other prisoners are named. When evaluating the three Egyptian names, all of them point to Late Period Egypt. ${ }^{44}$ Poti-

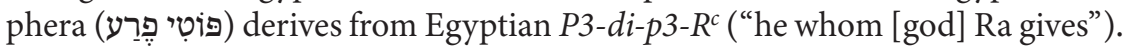
Names of the type P3-di-p3-NN"he whom god NN gives" (or "the one, given by the god NN") were not in use before first millennium всE. The same is true for

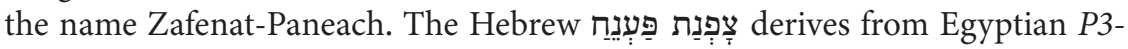
$d i-N \underline{t} r-i w=f-{ }^{c} n h$ ("the God speaks/spoke he shall live/he lives"). And the name Asenath (Ns-N.t, "belonging to Neith") refers to Neith, the main goddess of Sais, the capital of the Twenty-Sixth Dynasty.

In short, the Egyptian evidence in the Joseph story does not point to the late second millennium BCE but to the Neo-Babylonian and Persian period. ${ }^{45}$ This is also true for other motifs such as the 110 years, the embalming of the body which cannot be limited to the New Kingdom, and the title "overseers" in Gen 41:34 (in Hebrew פְִִּידִים ), which is an Aramaic title ubiquitous in the Egyptian administration during the Persian period. ${ }^{46}$

When turning from single motifs to the scope of the story, the aforementioned Sinuhe narrative comes into focus. ${ }^{47}$ Erhard Blum and Kristin Weingart have argued that the Joseph story should be seen as a "mirror narrative of the Sinuhe story from an Israelite-Levantine perspective." 48 For Blum and Weingart the similarities between both narratives are so close that the author of the Joseph story "was acquainted with the famous Sinuhe story from Egypt." Blum and Weingart list seven similarities which are more or less the same as mentioned by previous research. Scholars have long seen similarities between the Joseph story

${ }^{43}$ See M. Fieger and S. Hodel-Hoenes, Der Einzug in Ägypten: Ein Beitrag zur alttestamentlichen Josefsgeschichte (Bern: Peter Lang, 2007), 188-189, and for a detailed argumentation see B. U. SCHIPPER, "The History of Egyptology and the Gesenius Dictionary," in Biblische Exegese und Hebräische Lexikographie (ed. S. Schorch and E.-J. Waschke; BZAW 427; Berlin: Walter de Gryuter, 2013), 482-505, here 487-488.

${ }^{44}$ For the following see ibid., 498-499.

${ }^{45}$ See Redford, A Study on the Biblical Story of Joseph (see n. 6), 244. Several references to material from Late Period Egypt can also be found in Fieger and Hodel-Hoenes, Der Einzug in Ägypten (see n. 43), 368-370.

${ }^{46}$ See J. Hoftijzer and K. Jongeling, "pqd 2 ," DNWSI 2. 932-933.

${ }^{47}$ For the following paragraph see also B. U. SCHIPPER, "The Egyptian Background of the Joseph story," in New Perspectives on the Joseph story (ed. J. Joosten and B. U. Schipper; HeBAI 8/1; Tübingen: Mohr Siebeck, 2019), 6-23, here 9-12.

${ }^{48}$ Blum and Weingart, "The Joseph Story" (see n. 7), 515. 
and the Sinuhe story. ${ }^{49}$ The following set of narrative elements is mentioned with varying degrees of elaboration: ${ }^{50}$

(1) Sinuhe experiences his fate as guided by a divine plan.

(2) He meets the ruler of the foreign land.

(3) He rises to a prestigious position as the second in the ruler's family and marries the ruler's eldest daughter.

(4) He is given some of the best land on the border of upper Retjenu.

(5) He is regarded as everybody's favorite and becomes the ruler of a strong tribe.

(6) His sons, born by his foreign wife, themselves become leaders.

(7) $\mathrm{He}$ acts as a great benefactor to every person in need and becomes an asset for the land as a whole.

When looking at these motifs and the parallels in the Joseph story, there can be no doubt that, on a general level, there are similarities. In both narratives, we have an individual who travels to a foreign country, meets the ruler, rises to a prestigious position, marries someone from this country, and at the end expresses his wish to be buried in his homeland. But there are significant differences. When focusing on the details, it becomes clear that all seven motifs from the Sinuhe story that allegedly parallel the Joseph narrative have different meanings in the two tales. In the Sinuhe story, Amunenshi, the ruler of Upper Retjenu, placed Sinuhe "at the head of his children" and "joined" him to his eldest daughter" (B 78). ${ }^{51}$ Blum and Weingart point to Gen 41:40-45, where Joseph marries Asenath, the daughter of Potiphera, the priest of Heliopolis. But he is not the ruler of Egypt. Joseph is not married to a daughter of the Pharaoh. Furthermore, when looking at the actual Egyptian text, the marriage between Sinuhe and the daughter of the Asiatic ruler is described in an unusual way: "He staked me to his eldest daughter (78)." The Egyptian verb $m n i$ "to stake" (German: "anpflocken") indicates, as C.H. Gordon has shown, that Sinuhe was adopted by the ruler to marry his daughter. ${ }^{52}$

${ }^{49}$ See A. Meinhold, "Die Geschichte des Sinuhe und die alttestamentliche Diasporanovelle," $W Z(G) 20$ (1971), 277-281; J.R. KING, "The Joseph story and Divine Politics: A Comparative Study of a biographic Formula from the Ancient Near East," JBL 106/4 (1987), 577-595; E.W. Heaton, The School Tradition of the Old Testament: The Bampton Lectures from 1994 (Oxford: Oxford University Press, 1994), 58-59, 120-121; K. Koenen, "Zur Bedeutung von Gen 37,15-17 im Kontext der Josephs-Erzählung und von B 21-28 in der ägyptischen SinuheErzählung," BN 86 (1997), 51-56; Fieger and Hodel-Hoenes, Der Einzug in Ägypten (see n. 43), 354-357.

${ }^{50}$ Blum and Weingart, “The Joseph Story” (see n. 7), 514-515.

${ }^{51}$ R. КосH, Die Erzählung des Sinuhe (Bibliotheca Aegyptiaca 17; Brussels: Éd de la Fondation Égyptologique, 1990). A good English translation can be found in R. B. PArkinson, The Tale of Sinuhe and Other Ancient Egyptian Poems 1949-1640 BC (Oxford: Clarendon Press, 1997).

${ }^{52}$ C. H. Gordon, "The Marriage and Death of Sinuhe," in Love and Death in the Ancient Near East (FS Marvin H. Pope) (ed. J.H. Marks and R. McClive Good; Guilford, CT: Four Quarters, 1987), 43-44. 
Similarly, differences can also be found. The motif of divine guidance is a leading characteristic of the Sinuhe story, whereas in the Joseph story, it is not explicit in the storyline but only revealed at the end in Gen 50:22. ${ }^{53}$ The motif of a traveller becoming the ruler of a strong tribe refers to a tribe of the family of the foreign ruler in the Sinuhe story, whereas in the Joseph story it is connected with Jacob and his sons. ${ }^{54}$ In short, the similarities between the Joseph story and the Sinuhe narrative highlighted by previous research turn out to be general motifs embedded differently in the two narratives. These motifs can be connected with the so-called "fugitive hero narrative pattern," as Edward L. Greenstein has shown. Greenstein mentioned six extrabiblical narratives from the ancient Near East that date from the second millennium to the sixth century BCE. In these narratives, an individual must leave his homeland and survive a precarious exile. Among them are the stories of Esarhaddon, king of Assyria; the story of Nabonidus, king of Babylon; and the Sinuhe narrative. ${ }^{55}$ With slight differences, all of them share the same set of motifs:

1) the hero is a younger or youngest brother;

2) a political and/or personal crisis occurs;

3) a hero flees or is exiled;

4) a hero marries the daughter of his host in exile;

5) a hero assumes a position of responsibility in the host's household;

6) a hero has a divine encounter (often divination or revelation);

7) a hero is joined by kin.

For the interpretation of the Joseph story this means that the narrative should be seen within this tradition of the fugitive hero and not genetically connected to the story of Sinuhe. ${ }^{56}$ But even if one follows scholars such as Blum and Weingart and opts to connect Joseph and Sinuhe, this is not an argument for an early dating of the Joseph story because the story of Sinuhe was well known in the Egyptian Late Period. There is a citation in the so-called Piankhi-Stela from the late eighth century (Twenty-Fifth Dynasty) and some quotes from the Sinuhe story occur on private stelae from the seventh and sixth century (Twenty-Sixth Dynasty).

\footnotetext{
${ }^{53}$ For this motif see Schmid, "Die Josephsgeschichte im Pentateuch" (see n. 29), 112-115.

${ }^{54}$ For the differences see also Fieger and Hodel-Hoenes, Der Einzug in Ägypten (see n. 43), 354-355.

${ }^{55}$ See E. L. Greenstein, “The Fugitive Hero Narrative Pattern in Mesopotamia," in Worship, Women, and War (FS Susan Niditch) (ed. J. J. Collins et al.; BJS 357; Providence, RI: Brown University Press, 2015), 17-35.

${ }^{56}$ See N.-C. Grimal, La stele triomphale de Pi('nkh)y au Musée du Caire (Cairo: Institut français d’archéologie orientale, 1981), 284.
} 
Before turning to my own interpretation of the Joseph story's Egyptian background, a few words must be said on the second classical Egyptian parallel: the Tale of the Two Brothers. ${ }^{57}$

A number of scholars have argued that the seduction scene in Gen 39 was influenced by a similar scene in this Egyptian tale. Some believe that the motif of a woman who seeks to seduce a young man, as Potiphar's wife tries to seduce Joseph in Gen 39, comes from the Tale of the Two Brothers. ${ }^{58}$ Since this tale was popular in the Ramesside period, the argument is that the similarities point to an early date for the Joseph Story.

When examining Gen 39, two questions are important. First, is the seduction scene so unique that it points to a specific link between the two texts? And second, how does Gen 39 appear if one reads it against the backdrop of innerbiblical tradition? Even though the seduction scene in Gen 39 shares similarities with the Tale of the Two Brothers, ${ }^{59}$ it also differs. When evaluating Gen 39, it must be stated first and foremost that the scene in Potiphar's house has a certain function within the plot of the Joseph story: "Joseph's further career depend[s] on his being lodged in the place where the king's prisoners were bound." 60 This is the reason why Joseph is not punished with the death penalty, which would have been the normal punishment for such a crime. In contrast to the Egyptian tale, the innocence of the male actor is never proven, "nor is the punishment of the female actor recounted." 61

Since there is sapiential coloring in the Joseph Story, as scholars such as Gerhard von Rad and Michael Fox demonstrate, ${ }^{62}$ Gen 39 can rather receive its deeper meaning in light of the instructions on the seductive woman in the book

\footnotetext{
${ }^{57}$ See W. Wettengel, Die Erzählung von den beiden Brüdern: Der Papyrus d'Orbiney und die Königsideologie der Ramessiden (OBO 195; Göttingen: Vandenhoeck \& Ruprecht, 2003), 228-233; and Fieger and Hodel-Hoenes, Der Einzug in Ägypten (see n. 43), 96-101.

${ }^{58}$ Tower-Hollis, "Tale of Two Brothers" (see n. 8). See also C. Levin, "Righteousness in the Joseph Story," in The Pentateuch (ed. T.B. Dozeman et al.; FAT 78; Tübingen: Mohr Siebeck, 2011), 225-240, here 230 who called the Hebrew version a "remake."

${ }^{59}$ See the overview in Fieger and Hodel-Hoenes, Der Einzug in Ägypten (see n. 43), 99 100, and also H. Ringgren, "Die Versuchung Josefs (Gen 39)," in Die Väter Israels: Beiträge zur Theologie der Patriarchenüberlieferungen im Alten Testament (FS J. Schabert), (ed. M. Görg et al.; Stuttgart: Katholisches Bibelwerk, 1989), 267-270. A rather positivistic approach can be found in: R. Müller-Wollermann, "Das Motiv von Potiphars Frau und die altägyptische Realität," in Sexualität und Sklaverei (ed. I. Fischer and D. Feichtinger; AOAT 456; Münster: Ugarit-Verlag, 2018), 123-139.

${ }^{60}$ J. Skinner, A Critical and Exegetical Commentary on Genesis (2nd ed.; ICC; Edinburgh: T \& T Clark, 1930), 459.

${ }^{61}$ Levin, "Righteousness in the Joseph Story" (see n. 58), 230.

${ }^{62}$ von RaD, "The Joseph Narrative and Ancient Wisdom" (see n. 11), 292; and Fox, "Wisdom in the Joseph Story" (see n. 39), 31. For a fundamental critique of von Rad's position, see REDFORD, A Study of the Biblical Story of Joseph (see n. 6), 103-105 who argues that Joseph does not fit the wisdom ideal of the "long suffering, silent, modest man who controls his spirit" (here 104).
} 
of Proverbs. In Prov 5, 6, and 7, lectures warn a wisdom student about women. In particular, Prov 7 displays characteristic similarities with Gen 39:

- the woman is a foreigner (Prov 7:5; cf. 5:2; 6:24 - Gen 39:7; cf. 39:1)

- she is married (7:19, cf. Prov 6:26; 32 - Gen 39:7)

- the husband of the woman is not at home (7:19 - Gen 39:11)

- the woman wants to sleep with the young man (Prov 7:18 - Gen 39:7, 12)

The overview shows that Gen 39 shares more similarities with Prov 7 than with the sapiential instructions on the "strange woman" in Prov 6:20-35 and Prov 5:1-23. This makes sense since Prov 7:1-27 describes a scenario in which a young wisdom student should resist the seduction of an attractive woman. Interestingly, Prov 7 contains one detail that points to Egypt. The description of the bed prepared by the foreign woman in 7:16 refers explicitly to Egypt: "I have decked my

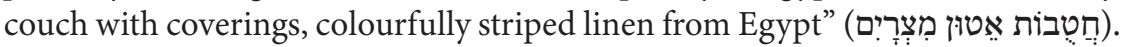

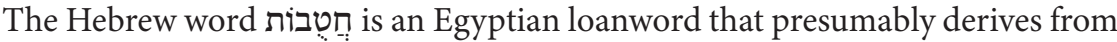
Egyptian $i d m . i$ ("red linen"). ${ }^{63}$

There are also differences since in Proverbs the foreign woman is described as beautiful and desirable, while in Gen 39:6 it is Joseph who is desirable and "beautiful" (יֶָָה). But these differences can be explained by the writer's creative license. Given that within the Joseph Story Joseph is portrayed in terms of wisdom, ${ }^{64}$ it is noteworthy that the following three motifs can be found in both the book of Proverbs and the Joseph Story:

- a foreign seductress,

- who is married,

- and an Israelite who should resist her. ${ }^{65}$

All of this shows that the famous scene of Gen 39 should rather be explained against the backdrop of the sapiential coloring of the Joseph story than to a particular Egyptian text or explicit historical moment.

Taken together, the main arguments of previous research for an early dating of the Egyptian background to the Joseph Story do not stand. Even though the Egyptian texts mentioned above share general similarities with the Joseph Story, neither the story's individual motifs nor its general plot demonstrably depend on a single source, whether the Sinuhe narrative or the Tale of the Two Brothers.

\footnotetext{
${ }^{63}$ See HALOT 37, DCH 1.202, and B. U. SCHIPPER, Proverbs 1-15 (Hermeneia; Minneapolis, MN: Fortress Presss, 2019), 270-271.

${ }^{64}$ See von RAD, "The Joseph Narrative and Ancient Wisdom” (see n. 11), 300.

${ }^{65}$ See Levin, "Righteousness in the Joseph Story" (see n. 58), 223-240.
} 


\section{Joseph, Ahiqar, and the Seven Years of Hunger}

In the following I will demonstrate that the Joseph story shares similarities in structure and content with the Ahiqar narrative and with an overlooked papyrus from the Berlin Museum. ${ }^{66}$ Even though the similarities of the Joseph story with the Berlin Papyrus are more striking than with the story of Ahiqar, the latter should be discussed as an example of a "courtier tale" that connects the Joseph story with other narratives from the Persian period. ${ }^{67}$

The "story of the wise Ahiqar" was already known to scholars from ancient sources in Syriac and Armenian ${ }^{68}$ before several sheets of papyri containing a hitherto unknown, older Aramaic version of the Ahiqar composition were retrieved from Elephantine in the spring of $1907 .{ }^{69}$ This find was groundbreaking for many reasons. First, it enables tracing back the tradition of the wise Ahiqar to its ancient sources in the middle of the first millennium вСE. Second, the find illustrates the reception of the Ahiqar composition, be it in Egyptian wisdom texts from the Ptolemaic period or in the book of Tobit, in which the plot of the Ahiqar narrative was used to portray a Jew living in the diaspora. ${ }^{70}$ As a "courtier tale," the story of Ahiqar can shed additional light on the Joseph story; therefore, its basic contours will be presented below.

The Ahiqar composition tells the story of a wise man at a royal court. The story is set in the Assyrian royal court of the early seventh century вСЕ,$^{71}$ presenting Ahiqar as a scribe and counselor of king Sennacherib of Assyria, "a great man" and "keeper of the seal" of the king, who "relies" on Ahiqar's counsel and advice. ${ }^{72}$ After the death of Sennacherib, his son Esarhaddon becomes king of Assyria.

${ }^{66}$ For the following see ScHIPPER, "Joseph, Ahiqar, and Elephantine” (see n. 9), 77-79.

${ }^{67}$ See for example S. White Crawford, "4QTales of the Persian Court (4Q550 a-e) and its Relation to Biblical Royal Courtier Tales, especially Esther, Daniel and Joseph," in The Bible as Book: The Hebrew Bible and the Judaean Desert Discoveries (ed. E. D. Herbert and E. Tov; London: Oak Knoll, 2002), 121-137.

${ }^{68}$ See J. R. HARris et al. (ed.), The Story of Ahikar (2nd ed.; Cambridge: Cambridge University Press, 1913), which is up to now the standard edition of the versions, including the original texts of the Syriac, Armenian, and other versions of the Ahiqar story.

${ }^{69}$ See the overview by J. M. Lindenberger, "Ahiqar (Seventh to Sixth Century B. C.): A New Translation and Introduction," in Expansions of the 'Old Testament' and Legends, Wisdom, and Philosophical Literature, Prayers, Psalms and Odes, Fragments of Lost Judeo-Hellenistic Works, Vol. 2 of The Old Testament Pseudepigrapha (ed. J.H. Charlesworth; Garden City and New York: Doubleday, 1985), 479-507, here 479-480.

${ }^{70}$ For the parallels between the Ahiqar sayings and the Demotic instruction of Khasheshonqi see M. Lichtheim, Late Egyptian Wisdom Literature in the International Context: A Study of Demotic Instructions (OBO 52; Fribourg and Göttingen: Vandenhoeck \& Ruprecht, 1983), 13-21.

${ }^{71}$ For a summary of the content see Lindenberger, "Ahiqar (Seventh to Sixth Century в. С.): A New Translation and Introduction” (see n. 69), 479. Sennacherib ruled from 705 to 681 BCE and Esarhaddon from 681 to 669 вСE.

${ }^{72}$ References to Ahiqar passages are from text C1.1, "Words of Ahiqar," in B. Porten and A. YARDENI, Literature, Accounts, Lists, Vol. 3 of Textbook of Aramaic Documents from Ancient Egypt (e. B. Porten and A. Yardeni; Jerusalem: Hebrew University Press, 1993), 24-53. 
Ahiqar, realizing that he is growing old without children of his own, decides to adopt his nephew, Nadin, as his successor. Nadin is educated and "presented to Esarhaddon, and in time takes his uncle's place at court."

Once he is installed in his new position, Nadin, instead of dealing kindly with his uncle, plots to discredit him. He tells the king (lines 26-27): "This old Ahiqar, who was keeper of the seal for your father, King Sennacherib, is subverting the land against you." ${ }^{73}$ When Esarhaddon hears the report of Nadin, the king becomes enraged and gives orders to kill Ahiqar. He instructs his officer Nabusumiskun: "Seek Ahiqar out and wherever you find him, kill him! Otherwise that old Ahiqar - wise and counselor of all Assyria that he was - is liable to subvert the land against us." ${ }^{\text {"4 }}$

When Nabusumiskun finds Ahiqar, he greets him with a remarkable phrase: "O wise scribe and master of good counsel, who used to be a righteous man."75 The following explains why Nabusumiskun calls Ahiqar "a righteous man." Ahiqar reminds Nabusumiskun what he did for him:

Indeed, I am the same Ahiqar who once long ago rescued you from an undeserved death, when King Esarhaddon's father Sennacherib was so angry with you that he sought to kill you. I took you directly to my own house and provided for you there, as a man would care for his own brother. I concealed you from him, saying, I have killed him, until an opportune time. Then, after a long time, I presented you to King Sennacherib and cleared you of the charges against you in his presence, so that he did you no harm. Indeed, King Sennacherib was grateful to me for having kept you alive rather than killing you. Now it is your turn to treat me as I treated you. ${ }^{76}$

This is the turning point of the story. Nabusumiskun agrees, ${ }^{77}$ and Ahiqar remains hidden in his house until there will be an opportunity for his redemption. At this point in the narrative, the Aramaic version from Elephantine, which is only preserved fragmentarily, breaks off. However, the later Syriac and other Christian versions tell us how the story ended. ${ }^{78}$ When a situation arose in which the Assyrian king needed special advice and neither the royal counselors nor Nadin could help, Nabusumiskun reveals that Ahiqar is not dead but still alive. In the end, Ahiqar is vindicated while his nephew Nadin, who defamed his uncle, is punished and killed. ${ }^{79}$

The story of Ahiqar represents, in some respects, what Michael Fox states for the Joseph story: "Wisdom literature recognizes that the wise and righteous

\footnotetext{
${ }^{73}$ Translation: Lindenberger, "Ahiqar (Seventh to Sixth Century B. C.): A New Translation and Introduction" (see n. 69), 495.

${ }^{74}$ Ibid., 496.

${ }^{75}$ Ibid.

${ }^{76}$ Ibid.

${ }^{77}$ According to the story, a slave was killed instead of Ahiqar, see ibid., 497.

${ }^{78}$ See HARRIS, The story of Ahikar (see n. 68).

${ }^{79}$ R. G. Kratz, "Mille Ahiqar: 'The Words of Ahiqar' and the Literature of the Jewish Diaspora in Ancient Egypt," Al-Abhath 60/61 (2012/2013), 39-58, here 44.
} 
might find themselves in hard times despite their virtues." ${ }^{\prime 0}$ Ahiqar is a wise and "righteous" man, as Nabusumiskun called him, who finds himself in a difficult position. ${ }^{81}$

The difficult position is resolved through Ahiqar's wisdom, calling upon Nabusumiskun's help by reminding him that "Now it is your turn to treat me as I treated you." 82 This sentence is crucial to the text since it illustrates two main aspects. First, it shows that Ahiqar argues in terms of wisdom: He refers to the relationship between act and consequence, which is the main motif of sapiential thought (the so-called "act-consequence-nexus"). And second, Ahiqar takes his fate into his own hands: He does not pray to a deity or expect direct help from God. Overall, the narrative of Ahiqar does not include a single reference to a particular god. Ahiqar acts as a wise man with skills and abilities that help him out of a life-threatening situation. In the story, Ahiqar tells the royal official Nabusumiskun exactly what he should do: "Do not kill me, but take me to your house until the times change."

In comparison with the Joseph story, some interesting similarities can be noted. Both stories recount the fall and rise of a wise man. In both narratives, this wise man is presented as a counselor of the king with access to the royal court. ${ }^{83}$ And, most interestingly, in both stories a life-threatening situation is changed by the protagonist himself, using his wisdom skills and his judiciousness. He helps himself by referring to a wisdom principle. Joseph and Ahiqar were, to describe it in the words of Donald B. Redford, "wrongly sentenced to death, prevented from entering the King's ken, and later rehabilitated." ${ }^{4}$ Both were personae non gratae who later, once rehabilitated, became important for the king in solving a problem.

These similarities become more crucial when considered together with the sayings of Ahiqar, which demonstrate a religious background for the sapiential behavior of the protagonist similar to that of the Joseph story. So, for example, a few sayings from the Ahiqar composition mention that the gods are the ultimate source of wisdom (Saying 13, Col VII 94) or that the righteous man is under the special protection of the deities (Saying 39, Col IV 126). ${ }^{85}$

${ }^{80}$ M.V. Fox, "Joseph and Wisdom," in The Book of Genesis: Composition, Reception, and Interpretation (ed. Craig A. Evans et al.; VTSup 152; Leiden: Brill, 2012), 231-62, here 258-60.

${ }^{81}$ M. WeIGL, "Die rettende Macht der Barmherzigkeit: Achikar im Buch Tobit," BZ 50/2 (2006), 212-242.

${ }^{82}$ Quote from Porten and Yardeni, "Words of Ahiqar" (see n. 72), C1.1: 51-52.

${ }^{83}$ It would go beyond this paper but should briefly be mentioned that the Ahiqar story also contains some features which can be compared to the Egyptian tradition. See S.A. BLEDsoe, "Wisdom in Distress: A Literary and Socio-Historical Approach to the Aramaic Book of Ahiqar," (PhD diss.; Florida State University, 2015).

${ }^{84}$ D. B. Redford, Egypt, Israel, and Canaan in Ancient Times (Princeton, NJ: Princeton University Press, 1993), 428-429 who also states: "The character and function of Joseph in the story in Genesis fits this role of savior and erstwhile persona non grata."

${ }^{85}$ See Lindenberger, "Ahiqar (Seventh to Sixth Century B. c.): A New Translation and Introduction" (see n. 69), 499 and 502-503. The religious dimension of Ahiqar comes through the 
Further comparison between the two narratives singles out a main motif of the Joseph story that is unparalleled in the Ahiqar narrative: the problem that Joseph has to solve. In the Ahiqar narrative, the problem does not seem to be existential. The later versions tell us that the king of Egypt challenged the Assyrian king in a series of riddles that could not be solved by Nadin or any other royal counselor. ${ }^{86}$ In contrast, the Joseph story mentions a serious problem to be solved.

Pharaoh has a dream in which he stands on the river Nile seeing seven cows coming out of the water, handsome and fat. Then seven other cows, ugly and gaunt, come up out of the Nile and eat the seven handsome, fat cows. The problem that Egypt faces in the Joseph story is a seven-year-long famine connected to the Nile (Gen 41).

It is well known that a parallel from ancient Egypt also exists for the motif of a period of seven years of hunger. The so-called "Famine Stela" ${ }^{87}$ found in 1889 on the island "Sehel" close to Elephantine, shares a number of motifs with the Joseph story. Like the Joseph novella, the Egyptian stela tells of a period of seven years of hunger that is connected to the Nile. To solve the problem, the king consulted a wise man, a certain priest, who looked into the sacred books. The following night the king has a dream in which the deity in control of the inundation appeared. This god promised the king the end of the famine. In gratitude to the god, the king issued a decree making a grant to the temple of this god. ${ }^{88}$ The text also states which god it is and where his temple can be found: It is Khnum, a ram-headed creator god who is worshipped in a temple on the island of Elephantine. ${ }^{89}$

What has been overlooked so far is that the "Famine Stela" stands within an inner-Egyptian tradition. The same set of motifs can be found in a newly discovered papyrus from the collection of the Egyptian Museum in Berlin. This papyrus (pBerlin 23071) bears a hieratic text datable to the Persian Period (fifth or fourth century BCE) on its verso. ${ }^{90}$ The papyrus belongs to the literary

combination between the Ahiqar sayings and the framing narrative, see Kratz, "Mille Ahiqar" (see n. 79), 47.

${ }^{86}$ See HARris, The story of Ahikar (see n. 68).

${ }^{87}$ See H. Brugsch, Die biblischen sieben Jahre der Hungersnoth nach dem Wortlaut einer altägyptischen Felsen-Inschrift (Leipzig: J.C. Hinrichs, 1891). For the history of research, see the overview by C. Peust, "Hungersnotstele," in Texte zum Rechts- und Wirtschaftsleben, Vol. 1 of Texte aus der Umwelt des Alten Testaments: Neue Folge (ed. B. Janowski and G. Wilhelm; Gütersloh: Gütersloher Verlagshaus, 2004), 208-217, here 208-210.

${ }^{88}$ An easily accessible English translation with brief introduction can be found in M. LicHTHEIM, The Late Period, Vol. 3 of Ancient Egyptian Literature (Berkeley, CA: University of California Press, 1980), 94-103.

${ }^{89}$ For the connection between the Famine Stela and Elephantine, see J. VANDIER, La famine dans l'Égypte ancienne (Recherches d'archéologie, de philologie et d'histoire 7; Cairo: Institut Français d’Archéologie Orientale, 1936), 42-43.

${ }^{90}$ G. Burkard, "Frühgeschichte und Römerzeit: P. Berlin 23071 VSO," Studien zur altägyptischen Kultur 17 (1990), 107-134, here 122, where he dated the text to the late Twenty-Sixth Dynasty. The papyrus itself dates to the first or second century CE; see J. F. QuACK, "Der his- 
tradition of the so-called "Book of the Temple" and contains the oldest version of the narrative introduction of this important text from Ptolemaic Egypt. ${ }^{91}$

Even though the Berlin papyrus is fragmentary, it is possible to say something about its content. The text reports on events from a bygone era. Under King Cheops, the famous builder of the great pyramid of Giza, there was a period of seven years in which the Nile did not overflow its banks. As a consequence, people were dying (l. $x+5)$, obviously out of a lack of food, and the temple collapsed. The situation changes when Pharaoh has a dream: ${ }^{92}$

$\mathrm{x}+5[\ldots]$ after dying. Then his majesty saw a dream in the night, saying to him:

$\mathrm{x}+6$ [... Go in each city of] Upper Egypt and go in each city of Lower Egypt. May you strongly establish the temple...

$\mathrm{x}+7$ [... of ] their gods. You must rebuild what has collapsed, and you must restore what has been recovered of that which was lost, and you must perform the ritual.

$\mathrm{x}+8[\ldots]$ this $[\ldots]$ in the temple of Atum, ruler of Heliopolis, according to ... the scriptures.

According to this text, the king should rebuild the temples of Egypt in the North (Lower Egypt) and in the South (Upper Egypt). He should consult the scriptures connected to the temple of Atum in Heliopolis. ${ }^{93}$ In the following lines, the Pharaoh is instructed to appoint a "supervisor of construction in the whole land" (l. $\mathrm{x}+12$, in Egyptian h hpr k3.wt $m$ t3 $[r] \underline{d} r[. w]=f) .{ }^{94}$

The last part of the text describes the activities of both the king and the appointed supervisor. Introduced by a classical phrase that all things are "back in their place" $(x+13)$, the text mentions temples of Upper and Lower Egypt that have all been re-established.

This text presents the same set of motifs as in the Famine Stela from the Ptolemaic period.

torische Abschnitt des Buches vom Tempel," in Literatur und Politik im pharaonischen und ptolemäischen Ägypten (ed. J. Assmann and E. Blumenthal; Bibliothèque d'Étude 127; Cairo: Institut Français d’Archéologie Orientale, 1999), 267-278, here 277.

${ }^{91}$ Ibid.

92 The text follows the German edition and translation from Burkard, "Frühgeschichte und Römerzeit: P. Berlin 23071 VSO” (see n. 90), 113. For a slightly different German translation, see also J. F. QuACK, "Danaergeschenk des Nil? Zu viel oder zu wenig Wasser im Alten Ägypten," in Disaster and Relief Management: Katastrophen und ihre Bewältigungen (ed. A. Berlejung; FAT 81; Tübingen: Mohr Siebeck, 2012), 334-381, here 349.

${ }^{93}$ According to the parallel versions of the "historical introduction" of the Book of the Temple, the scriptures were found in Heliopolis; see QUACK, "Der historische Abschnitt des Buches vom Tempel" (see n. 90), 274.

${ }^{94}$ See Burkard, "Frühgeschichte und Römerzeit: P. Berlin 23071 VSO" (see n. 90), 114. Quack translates it with "architect"; see QuACK, "Der historische Abschnitt des Buches vom Tempel" (see n. 90), 274. For the title hpr k3.wt see F. Steinmann, "Untersuchungen zu den in der handwerklich-künstlerischen Produktion beschäftigten Personen und Berufungsgruppen des Neuen Reiches," ZÄS 107/1 (1980), 137-157, here 146. 
(1) In both texts, pBerlin 23071vs. and the Famine Stela, a time of chaos is mentioned and connected to a period of seven years.

(2) Both texts mention a dream of the Pharaoh.

(3) Both texts connect the concrete activities with a special official who is appointed by the Pharaoh.

(4) Both texts have a special interest in a certain temple and its priesthood, presenting this temple as the most important cult place of Egypt. In the Berlin papyrus, this is the temple of Heliopolis, and in the Famine Stela it is the temple of Elephantine.

Strictly speaking, all the motifs in the Joseph story that can be related to the Famine Stela, can already be found in the Berlin papyrus:

(1) the seven years

(2) the lack of inundation that caused a famine (people were dying)

(3) the dream of the Pharaoh ${ }^{95}$

(4) an overseer or supervisor who is appointed to solve the problem

(5) this supervisor is appointed by the king himself

Interestingly, the Berlin papyrus presents another similarity with the Joseph story: The temple of Heliopolis. According to Gen 41:45, Joseph married Asenath, the daughter of Potiphera, who was priest of Heliopolis (On). If we look for Egyptian names and places in Gen 37-50, the only religious site mentioned in the whole Joseph story is Heliopolis. ${ }^{96}$ In sum, the Joseph story shares more similarities with Papyrus Berlin 23071vs. than with the Famine Stela. Given that the Berlin papyrus dates to the Persian period, the similarities to the Joseph story fall in the same time as the oldest version of the Aramaic Ahiqar composition from Elephantine. Thus, the same motifs driving the Joseph narrative's storyline can be found in these two texts from Egypt, which both date to the Persian period.

When we summarize the discussed evidence so far, three results are important:

(1) Regarding the Egyptian background of the text, there can be no doubt that a number of individual motifs within the Joseph story point to the first millennium вCE, not to the New Kingdom. This is true for the personal names, for the scene of Joseph's inauguration in Gen 41:42, and for some other motifs.

(2) When investigating the main motifs and their arrangement, two sets are important. First, the story of the wise men who confront a dangerous situation

\footnotetext{
${ }^{95}$ See also N. Shupak, who tried to connect the dream motif in the Joseph story with Egyptian Demotic literature: N. Shupak, "A Fresh Look at the Dreams of the Officials and of the Pharaoh in the story of Joseph (Genesis 40-41) in Light of Egyptian Dreams," JANES 30/1 (2006), 103138, here 108.

${ }^{96}$ The other Egyptian toponyms refer to cities or to areas: Ramses (Gen 47:11) and the land of Goshen (Gen 45:10; 46:28, 34; 47:1, 27; 50:8). Interestingly, neither the place where Joseph served as slave nor where the Pharaoh lives are mentioned, see G. Pfeifer, Ägypten im Alten Testament (BN.B 8; Munich: Institut für Biblische Exegese, 1995), 27.
} 
and solve it by using their skills and the principles of wisdom; and second, the cluster of motifs from Papyrus Berlin 23071vs. Ahiqar and Joseph both refer to the principle of reciprocity and taking fate in one's own hands. ${ }^{97}$ Furthermore, the main motifs connected to the subject of the seven years of hunger can be found in both the Joseph story and the narrative introduction of the Book of the Temple on Papyrus Berlin 23071vs.

(3) In sum, the Ahiqar narrative and Papyrus Berlin 23071vs share the main motifs that drive the storyline of the Joseph story: the endangered but wise hero, the importance of dreams, and a problem Joseph must solve.

\section{Joseph in Egypt. A Possible Historical Setting}

When considering a possible socio-historical setting of the Joseph story, one topographical element in the aforementioned texts is interesting. Both the Ahiqar narrative and the tradition of the seven years of hunger are connected to Elephantine. The Ahiqar-composition comes from there, and the Famine Stela from the island of Sehel mentions the ram-headed god Khnum of Elephantine. During the fifth and early fourth centuries BCE, the island of Elephantine with its famous temple of Khnum hosted a Persian military garrison. According to the Aramaic papyri found on the island in the early twentieth century, it was home to several ethnicities. ${ }^{98}$ Persian-period Elephantine was in some respects a multicultural society with Greeks, Phoenicians, Egyptians, and "Judeans/Aramaens," as the people who came from Israel to Elephantine called themselves. ${ }^{99}$ According to the famous letter from the year $407 \mathrm{BCE}$, there was a rivalry between the worshippers of the god Yhwh, called Yaho, and the priesthood of the temple of Khnum. The Egyptian priests destroyed the temple of Yaho and a group of priests led by a certain Jedoniah wrote to the governor of the Persian province Yehud to for help getting permission for rebuilding the temple. ${ }^{100}$

\footnotetext{
${ }^{97}$ In this respect the Joseph story can also be related to the Egyptian Aramaic "Prophecy of Hor bar Punesh"; see B. Porten, "The Prophecy of Hor Bar Punesh and the Demise of Righteousness: An Aramaic Papyrus in the British Library," in Res severa verum gaudium: Festschrift für Karl-Theodor Zauzich zum 65. Geburtstag am 8. Juni 2004 (ed. F. Hoffmann and H.J. Thissen; Studia Demotica 6; Leuven: Peeters, 2004), 427-466, here 435 and plates xxxv-xxxvi.

${ }^{98}$ For the following, see B. U. SCHIPPER, A Concise History of Ancient Israel (Critical Studies in the Hebrew Bible 11; Winona Lake, IN: Eisenbrauns, 2019), 80-84 and R. G. Kratz, Historical and Biblical Israel: The History, Traditions, and Archives of Israel and Judah (Oxford: Oxford University Press, 2015), 137-147.

${ }^{99}$ B. BecKing, "Yehudite Identity in Elephantine," in Judah and the Judaeans in the Achaemenid Period (ed. O. Lipschitz et al.; Winona Lake, IN: Eisenbrauns, 2011), 403-419. See also K. van Der Toorn, "Ethnicity at Elephantine: Jews, Arameans, Caspians," Tel Aviv 43/2 (2016), 147-164.

${ }^{100}$ B. Porten and A. Yardeni, Letters, Vol. 1 of Textbook of Aramaic Documents from Ancient Egypt (Jerusalem: Hebrew University Press, 1986), A 4.7 (Version A), esp. 1l. 23-25.
} 
Other letters from Elephantine provide insight into the life of this multicultural society. They report, for example, about a Judahite woman who was later married to an Egyptian ${ }^{101}$ or a certain Anani, son of Haggai, who worked for an Egyptian and was paid with a grain ration from the royal storehouse. ${ }^{102}$ The evidence from Elephantine shows that the Judaean/Aramaic community from the fifth/early fourth century BCE was neither isolated from Israel/Palestine nor from the Egyptians on Elephantine.

If one combines this evidence with the Joseph story, interesting similarities emerge. The Joseph novella tells the story of an Israelite man, Joseph, who makes a career for himself in Egypt. This man marries an Egyptian woman and lives in the diaspora. It is often stated that the marriage of Joseph with Asenath, the daughter of the priest of Heliopolis, sharply contrasts the conception of identity on display in the book of Ezra-Nehemiah, where "mixed marriage" is forbidden (see Ezra 9:1-4; 10:1-17; Neh 10:30-31; 13:23-27). But in the Joseph story, a marriage with a foreign woman is allowed. ${ }^{103}$ Thus, the concept of identity in the Joseph story fits nicely with what we can reconstruct about the "Judean/ Aramaic" community at Elephantine. Against this backdrop, it seems likely that the social milieu for which the Joseph story was written was not in Palestine/Israel. It has often been stated that the Joseph novella presents a different concept of identity than the ancestral narratives. Redford summarized this evidence as follows: The Joseph story "brings all the sons of Jacob to Egypt, where they live out their lives, even the 'baby' Benjamin already blessed with ten sons! This contradicts emphatically the traditions of individual tribes in later times in which the eponymous ancestors live, marry, raise families, and die in Canaan."104

Whereas the ancestral narratives present the main idea of Israel's existence in the land, the Joseph story contains a unique conception of identity, arguing for a life in the diaspora. It is a life in a foreign country in which an Israelite's career is possible and this Israelite is allowed to marry a woman from that land. ${ }^{105}$ Therefore, Thomas Römer and Reinhard G. Kratz seem right in connecting the Joseph

Compare A 4.8 (Version B). For a new interpretation see B. U. Schipper, "Die Judäer/Aramäer von Elephantine und ihre Religion," ZAW 132/1 (2020), 1-27.

${ }^{101}$ Several marriage contracts were found which mention rights and prices (for example for a linen garment). See A. Azzoni, The Private Lives of Women in Persian Egypt (Winona Lake, IN: Eisenbrauns, 2013), 81-99.

102 B. Porten, "The Jews in Egypt," in Introduction: The Persian Period, Vol. 1 of The Cambridge History of Judaism (ed. W.D. Davies and L. Finkelstein; Cambridge: Cambridge University Press, 1984), 372-400, here 383.

${ }^{103}$ See C. Frevel (ed.), Mixed Marriages: Intermarriage and Group Identity in the Second Temple Period (LHB 547; London: T\&T Clark, 2011).

${ }^{104}$ Redford, Egypt, Israel, and Canaan in Ancient Times (see n. 85), 423-424.

${ }^{105}$ See Schмid, "Die Josephsgeschichte im Pentateuch" (see n. 29), 111; and Евасн, Genesis 37-50 (see n. 31), 693: "Die 'Botschaft' der Geschichte ist, dass man auch im fremden Land überleben und leben kann." 
story with the Egyptian diaspora of the Persian period. ${ }^{106}$ As Kratz puts it, "In the Joseph story the Egyptian Diaspora makes itself heard and clearly indicates that there are also Israelites outside Judah and the other territories in the land inhabited by Israelites." 107 Thus, the Joseph story is best understood as a "diasporanovella," since it can be connected to a diaspora context. ${ }^{108}$

Evidence from Persian-period Egypt is important for describing this diaspora context. In his studies on the Persian administration in Egypt, Alexander Schütze has shown that the Persians took over important posts in the provincial administration, while the Egyptians remained mainly in lower-level positions. According to him, "Egypt was administered by multi-ethnic personnel." ${ }^{109} \mathrm{We}$ have archaeological evidence for foreign personnel, such as the Aramaic documents from Elephantine, Saqqara, and other places as well as archaeological artefacts. Egyptian-Aramaic funerary stelae display a combination of Mesopotamian traditions and elements of Egyptian religion by foreign officials. On the one hand, the owners of the stelae bear Aramaic or Semitic names while, on the other, the stelae themselves are composed in an Egyptian or in some cases in an "Egyptianized" way. ${ }^{110}$

One of the most interesting "Aramaic-Egyptian Stelae" is a piece from the Berlin collection. The stela Berlin 7707, published by Richard Lepsius in $1877,{ }^{111}$ is a funerary stela from Saqqara with a unique combination of Egyptian motifs and Aramaic text. Already Richard Lepsius emphasized that the hieroglyphic inscriptions in the upper register are unusual and located in the wrong place. The inscription on the left side, for example, runs from left to right, which stands in contrast to the deities which look to the right. Given the direction of the deities, the inscription should run from right to left and not the other way around. ${ }^{112}$ Another irregularity is that the name of the owner of the stela, a woman with the Aramaic name "Ahatabu" ("the father's sister") is placed in the hieroglyphic in-

106 T. RÖMER, "La narration, une subversion: L'histoire de Joseph (Gn 37-50^) et les romans de la diaspora," in Narrativity in Biblical and Related Texts (ed. G. J. Brooke and J.-D. Kaestli; Leuven: Leuven University Press, 2000), 17-29, here 28-29.

${ }^{107}$ Kratz, The Composition of the Narrative Books of the Old Testament (see n. 15), 279.

108 See A. Meinhold, "Die Gattung der Josephsgeschichte und des Estherbuches: Diasporanovelle I," ZAW 87/3 (1975), 306-324; IDEM, “Die Gattung der Josephsgeschichte und des Estherbuches: Diasporanovelle II," ZAW 88/1 (1976), 72-79; and for a detailed argument, Schipper, "Joseph, Ahiqar, and Elephantine" (see n. 9), 79-80.

${ }^{109}$ A. Schütze, "Local Administration in Persian Period Egypt According to Aramaic and Demotic Sources," in Administration in Achaemenid Empire (ed. B. Jacobs et al.; Classica et Orientalia 17; Wiesbaden: Harrassowitz, 2017), 489-515, here 489-451.

110 The best overview is in G. Vittmann, Ägypten und die Fremden im ersten vorchristlichen Jahrtausend (Mainz: Philipp von Zabern, 2003), 106-110. And more recently, IDEM, "Arameans in Egypt," in Wandering Arameans: Arameans Outside Syria: Textual and Archaeological Perspectives (ed. A. Berlejung et al.; Leipziger Altorientalische Studien 5; Wiesbaden: Harrassowitz, 2017), 229-279, here 248-249, 254-256.

111 See R. LEPSIUs, “Eine ägyptisch-aramäische Stele,” Z̈̈S 15 (1877), 127-132.

112 Ibid., "Eine ägyptisch-aramäische Stele," (see n. 111), 128. 


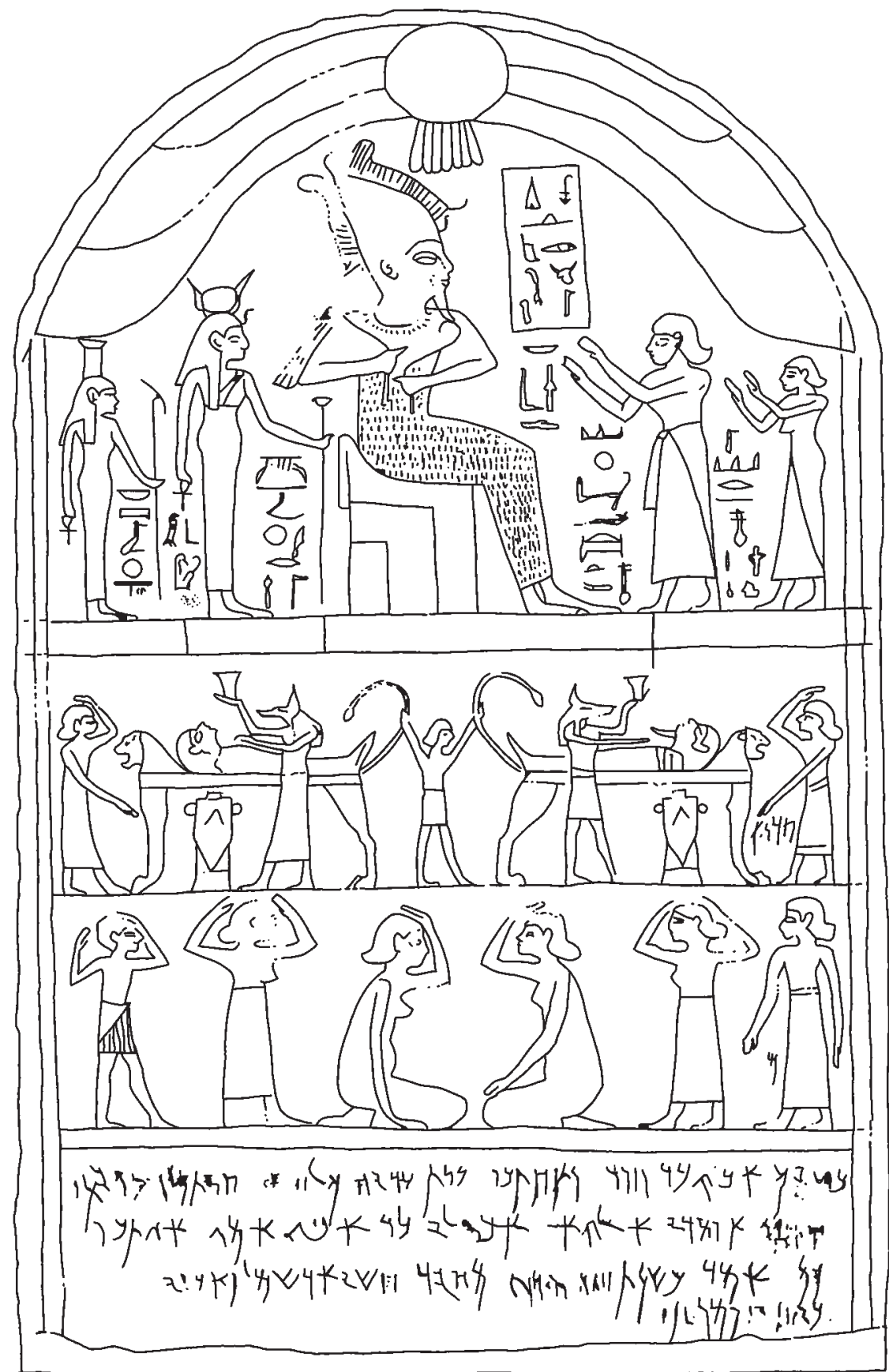

Fig. 1: Berlin Stela 7707 (Saqqara), drawing by Maria Bruske 
scription (3ht $3 b w)$ between the goddesses Isis and Nephthys. The name of the woman appears also in the Aramaic inscription (1. 1, אחתבו), which mentions also a man "Abah" (1. 1, אבה) whose father has an Egyptian name (Hor = Horus). Given that the son who donated the stela bears an Akkadian name (1.2, אבסלי = lbašši $-i \bar{l} \bar{l}),{ }^{113}$ we have three generations of one family with three different name types: Egyptian, Aramaic, and Akkadian.

The stela presents a remarkable combination of Egyptian, Persian, and Syrian motifs. The god Osiris in the upper register and the mummification in the middle register are classic Egyptian; the style of the winged solar disk displays Persian influence; and some of the men in the lower and middle register wear a long Syrian hairdo. Interestingly, 1.3 of the Aramaic inscription has a reference to the Persian king Xerxes I.: "in year 4, month of Mehir, of Xerxes the king" (בשנת בי 4 (4). The word order of the formula with year, month, and king "follows the Egyptian pattern" and not the Aramaic one as B. Porten and J. Gee has pointed out. ${ }^{114}$ The Berlin Stela 7707 is the only dated stela among the corpus of the Egyptian-Aramaic stelae from Persian-period Egypt.

In sum, the Aramaic-Egyptian funerary stelae provide insights into the effects of Persian policy. The Persian authorities were interested in a multicultural elite administration that came from the Levant and served in Egypt. These people were familiar with Egyptian religion but kept their Aramaic heritage, expressed in the Aramaic language on the funerary stelae.

Even if one cannot connect the Egyptian-Aramaic funerary stelae in a direct way with the Joseph story, one aspect seems important. If one searches for a possible socio-political background for the conception of identity presented in the Joseph story, the situation in Persian-period Egypt comes into focus. The idea of a foreign identity for Judaeans/Israelites in Egypt with a marriage to an Egyptian woman (in the Joseph story Asenath) and a career in the Egyptian administration (Joseph in Gen 41) fits nicely with what we know about foreigners from the Levant working in the Persian administration of Egypt. Interestingly, a fragmentary Egyptian-Aramaic funerary stela from Saqqara mentions a "Judean" name with reference to the god Yahu ("Blessed is/be Peteese son of Yeha[---]"). ${ }^{115}$

In sum, Egyptian background of the Joseph story does not point to the New Kingdom but to Late Period Egypt. The Joseph story displays not only striking similarities to Papyrus Berlin 2307lvs and the Ahiqar narrative from Elephantine,

${ }^{113}$ See Vittmann, Ägypten und die Fremden (see n. 110), 106. For a more detailed analysis of the stela see B. U. Schipper, "Die ägyptisch-aramäischen Stelen der Perserzeit," in 40 Jahre Ägypten und Altes Testament (ed. S. J. Wimmer and W. Zwickel; Ägypten und Altes Testament 100; Münster: Zaphon, 2021), forthcoming.

${ }^{114}$ See B. Porten and J. Gee, "Aramaic Funerary Practices in Egypt," in The World of the Arameans: Studies in History and Archaeology in Honour of Paul-Eugene Dion (ed. P. M. M. Daviau et al.; JSOTSup 325; Sheffield: Sheffield University Press, 2001), 270-307, here 292.

${ }^{115}$ See VittmanN, "Aramaeans in Egypt" (see n. 110), 255 with further discussion. 
but receives its deeper meaning from the aforementioned situation in Egypt during the first Persian domination (Twenty-Seventh Dynasty). 



\section{List of Contributors}

Samuel Arnet is research assistant at the chair of Old Testament Studies and Early Jewish History of Religion (Prof. K. Schmid) at the University of Zurich.

Franziska Ede is research assistant at the chair of Old Testament (Prof. R. Kratz) at the Theological Faculty of the University of Göttingen.

Camille Guerin has received her PhD (Dir. K. Berthelot and B. Mathieu) at the Institut de Recherches et d'Etudes sur les Mondes Arabes et Musulmans at Aixen-Provence.

Reinhard Kratz is Full Professor for Old Testament at the Theological Faculty of the University of Göttingen.

Safwat Marzouk is Associate Professor of Old Testament/Hebrew Bible at the Anabaptist Mennonite Biblical Seminary.

Lauren Monroe is Associate Professor at the department of Near Eastern studies at the Cornell University.

Thomas Römer is Professor at the chair "Milieux bibliques" at the Collège de France.

Bernd U. Schipper is Professor of Hebrew Bible/Old Testament - History of Israel in the Ancient Near East at the Humboldt University of Berlin.

Konrad Schmid is Professor for Old Testament Studies and Early Jewish History of Religion at the Theological Faculty of the University of Zurich. 



\section{Index of References}

\section{Biblical texts}

$\begin{array}{llll}\text { Genesis } & & 37: 33 & 93 \\ 12: 3 & 104 & 37: 34-35 & 16 \\ 16: 7 & 107 & 38 & 70 \\ 18: 2 & 107 & 38: 27-30 & 75 \\ 18: 10 & 9 & 39 & 103,116,144-145, \\ 21 & 9 & & 150-151 \\ 21: 2 & 8-9 & 39: 1 & 70,91,151 \\ 21: 7 & 8-9 & 39: 2 & 69-70 \\ 26: 35 & 75 & 39: 3-4 & 69 \\ 27: 46 & 75 & 39: 6 & 151 \\ 29-30 & 7,9,15 & 39: 7 & 69,151 \\ 29: 30-31 & 8,10 & 39: 11 & 151 \\ 29: 31-30: 24 & 81 & 39: 12 & 93,151 \\ 30 & 58 & 39: 21 & 69,145 \\ 30: 24 & 23 & 39: 22 & 69 \\ 30: 27 & 78 & 39: 23 & 69 \\ 32 & 25 & 39-40 & 37-38 \\ 32: 23-32 & 131 & 39-41 & 24,58,60,68-73,140 \\ 32: 23-33 & 107 & 39-47 & 143 \\ 32: 29 & 7,10 & 39: 4 & 71 \\ 33: 1-20 & 48 & 40: 8 & 47 \\ 34: 7 & 97 & 40: 15 & 133-134 \\ 35: 29 & 48 & 40: 20-22 & 48 \\ 37 & 5,9-10,15,26,39,58, & 41 & 83,162,124-126,155 \\ & 70-71,87,104-118,140, & 41: 1-13 & 134-135 \\ 37: 3-5 & 143,144,146 & 41: 14 & 80-81 \\ 37: 5-9 & 6-9,13-14 & 41: 15-16 & 47,81,83 \\ 37: 8 & 6,10-14,105-106 & 41: 25 & 47,83 \\ 37: 9-10 & 41,106 & 41: 25-56 & 37 \\ 37: 9-11 & 47-48 & 41: 25-45 & 44 \\ 37: 12-13 & 107-110,113 & 41: 28 & 83 \\ 37: 14 & 143 & 41: 32 & 83 \\ 37: 14-17 & 48-49,91 & 41: 33 & 145 \\ 37: 19-20 & 106-107 & 41: 33-39 & 80,81 \\ 37: 23 & 93-14,143-144 & 41: 38-39 & 83,135,145 \\ 37: 24-25 & 91 & 41: 40-43 & 126-127 \\ 37: 25 & 91,120-123 & 41: 40-44 & 80 \\ 37: 32 & 88 & 41: 40-45 & 148 \\ & & 41: 41 & 70 \\ & & & \end{array}$




\begin{tabular}{|c|c|c|c|}
\hline $41: 42$ & $93,146,157$ & $47: 13$ & 70 \\
\hline $41: 43$ & 147 & $47: 13-26$ & $37,51-52$ \\
\hline $41: 46$ & 82 & $47: 14-23$ & 69 \\
\hline \multirow[t]{2}{*}{$41: 45$} & $42,50,64,71,76,80,81$ & $47: 14-24$ & 71 \\
\hline & $130-133,147,157$ & $47: 15-26$ & 71 \\
\hline $41: 47-48$ & 71 & $47: 25$ & 71 \\
\hline $41: 50$ & 76 & $47: 26-27$ & 71 \\
\hline $41: 51-52$ & $42,81,95$ & $47: 29-31$ & $17-18,20$ \\
\hline $41: 54 b-57$ & 70 & $48-50$ & 20 \\
\hline $41: 55$ & 80,81 & $49: 33$ & $17-18$ \\
\hline 42 & 12,70 & 50 & $94,140,143,144$ \\
\hline $42: 4$ & 110 & $50: 1$ & 18,20 \\
\hline $42: 6$ & 13,70 & $50: 2-3$ & $42,127-128$ \\
\hline $42: 9$ & 13 & $50: 4-8$ & 80 \\
\hline $42-44$ & $87-94$ & $50: 7$ & 18 \\
\hline $42-45$ & 140 & $50: 10$ & 18 \\
\hline $42-47: 12$ & 70 & $50: 13$ & 48 \\
\hline $43: 27-28$ & 100 & $50: 14$ & 18 \\
\hline $43: 32$ & 44,80 & $50: 15-22$ & $112-114$ \\
\hline $43: 34$ & 41 & $50: 18$ & 144 \\
\hline 44 & $77-78$ & $50: 18$ & 113 \\
\hline $44: 1-13$ & 41 & $50: 19$ & $47,99,144,145$ \\
\hline $44: 4-5$ & $42,77,78,79$ & $50: 20$ & 92,144 \\
\hline $44: 15$ & 78,79 & $50: 20-21$ & $116-117$ \\
\hline $44: 16$ & 113 & $50: 22$ & $129-130,149$ \\
\hline $44: 18$ & 96 & $50: 23$ & 76 \\
\hline $44: 18-34$ & $38,111-112$ & $50: 24-25$ & 38 \\
\hline $44: 34$ & 111 & & \\
\hline 45 & 41,111 & Exodus & \\
\hline $45: 1-2$ & 89,96 & $1: 8-16,22$ & 80 \\
\hline $45: 1-15$ & $94-100$ & $1: 6-7$ & 42,117 \\
\hline $45: 4-7$ & 13 & $1: 6-8$ & 142 \\
\hline $45: 17-21$ & 80,81 & $1: 9$ & 21 \\
\hline $45: 22$ & 93 & $1-15$ & 117 \\
\hline $45: 25-28$ & $15-18$ & $6: 6-7$ & 63 \\
\hline $45: 27$ & 100 & $7: 11$ & 135 \\
\hline $46-49$ & 140 & $7: 14$ & 80 \\
\hline $46-50$ & 27,142 & $8: 11$ & 80 \\
\hline $46: 1$ & $16-17$ & $14-15$ & 115 \\
\hline $46: 10$ & 75 & $15: 2,21$ & 80 \\
\hline $46: 20$ & 76 & $15: 15$ & 96 \\
\hline $46: 29-30$ & 17 & $20: 2$ & 80 \\
\hline $46: 30-34$ & 19 & $34: 15-16$ & 75 \\
\hline $46: 34$ & 80 & & \\
\hline 47 & $70-71$ & Leviticus & \\
\hline $47: 5-6$ & 80,81 & $19: 26$ & 78,93 \\
\hline $47: 11$ & 80 & & \\
\hline
\end{tabular}




\begin{tabular}{|c|c|c|c|}
\hline \multicolumn{2}{|l|}{ Numbers } & \multicolumn{2}{|l|}{ Isaiah } \\
\hline $1-2$ & 39 & 18 & 80 \\
\hline $25: 1-2$ & 75 & 19 & 80 \\
\hline \multicolumn{2}{|c|}{ Deuteronomy } & \multicolumn{2}{|l|}{ Jeremiah } \\
\hline $7: 3-4$ & 75 & 7 & 33 \\
\hline $18: 9-12,14$ & 78,93 & $29: 6$ & 76 \\
\hline \multirow{2}{*}{$34: 4$} & 38 & 41 & 33,98 \\
\hline & & $41-44$ & 28 \\
\hline Joshua & & $42: 16$ & 98 \\
\hline 5 & 107 & $42: 17$ & 98 \\
\hline $17: 14-17$ & $59,62-63$ & $42-44$ & 80 \\
\hline $18: 15$ & 59 & $43: 11$ & 98 \\
\hline \multirow[t]{2}{*}{$24: 32$} & 38,42 & 44 & 33 \\
\hline & & $44: 12$ & 98 \\
\hline Judges & & 46 & 80 \\
\hline $1: 22-23$ & 59 & & \\
\hline $1: 34-35$ & $59,64-65,66,67$ & Ezekiel & \\
\hline 9 & 66 & $29-32$ & 80 \\
\hline $20: 41$ & 96 & $37: 19$ & 86 \\
\hline \multicolumn{2}{|l|}{2 Samuel } & Amos & \\
\hline 13 & 111 & $5: 6$ & 59 \\
\hline 16 & 61 & & \\
\hline $19: 20-21$ & $59,61-63,66,73$ & Obadiah & \\
\hline $19: 23$ & 63 & Obadiah & 59 \\
\hline \multicolumn{2}{|l|}{1 Kings } & \multicolumn{2}{|l|}{ Zechariah } \\
\hline $3: 1$ & 75 & $10: 6$ & 59 \\
\hline $3: 5-11$ & $75-76$ & & \\
\hline $4-5$ & 64 & Psalms & \\
\hline $4: 8$ & 63 & $81: 6$ & 64 \\
\hline $5: 27$ & 63 & $148: 1,3$ & 109 \\
\hline $7: 8$ & 75 & & \\
\hline $9: 16$ & 75 & $J o b$ & \\
\hline $9: 24$ & 75 & $38: 6,7$ & 109 \\
\hline $11-14$ & 26 & & \\
\hline $11: 1,3-4,9$ & 76 & Proverbs & \\
\hline $11: 28$ & $59,63-64,66,67,73$ & $5: 1-23$ & 151 \\
\hline $11: 40$ & 67 & $5: 2$ & 151 \\
\hline \multirow[t]{2}{*}{18} & 115 & $6: 20-35$ & 151 \\
\hline & & $6: 24$ & 151 \\
\hline 2 Kings & & $6: 26$ & 151 \\
\hline $17: 17-18$ & $78,93,103$ & $6: 32$ & 151 \\
\hline $21: 6$ & 78 & $7: 1-27$ & 151 \\
\hline $23: 34$ & 82 & $7: 5$ & 151 \\
\hline $24: 17$ & 82 & $7: 16$ & 151 \\
\hline 25 & 103 & $7: 18$ & 151 \\
\hline
\end{tabular}




$\begin{array}{llll}7: 19 & 151 & \text { Daniel } & \\ 16: 9 & 117,146 & 1: 3-6,7 & 83 \\ 16: 23 & 116 & 1-6 & 117 \\ 20: 24 & 117 & 2-6 & 43 \\ 23,27-28 & 116 & & \\ 25,11 & 116 & \text { Ezra } & \\ & & 9: 1-4 & 159 \\ \text { Ruth } & & 10: 1-17 & 159 \\ 1: 1-5 & 76 & & \\ 1: 17 & 77 & \text { Nehemiah } & \\ 2: 1 & 76 & 9: 6 & 47 \\ 4: 13 & 76 & 10: 30-31 & 159 \\ 4: 17 & 76 & 13: 23-27 & 159 \\ 4: 22 & 76 & & \\ & & 2 \text { Chronicles } & \\ \text { Qohelet } & & 33: 6 & 78 \\ 5: 1 & 114 & 36: 4 & 82 \\ 8: 3 & 96 & & \end{array}$

Non-canonical Jewish texts

Dead Sea Scrolls 4Q371-373

33

Josephus

Joseph and Aseneth

Jewish Antiquities

$1: 222$

2.6.1§91 81

Letter of Aristeas

28, 46

11.321-322 45

$12: 7 \quad 52$

$12.710 \quad 45$

13.74-79 45

\section{LXX manuscripts}

Rahlfs

$819 \quad 47$

801

47

957

47

\section{Egyptian texts}

$\begin{array}{llll}\text { Amarna Letter EA 365 } & 66-67 & \text { Instruction of Ptahhotep 129 } \\ \text { Berlin Stela 7707 } & 160-162 & \text { Nauri Decree } & 126 \\ \text { Saqqarah block statue } & & \text { Papyrus Berlin 23071vs } & 50,155-158,162 \\ \text { CG 604 } & 129 & \text { Papyrus BM 10565 } & 50 \\ \text { Book of the Temple } & 50,156 & \text { Papyrus Bologna 1086 } & 120 \\ \text { Famine Stela } & 49,155-158 & \text { Papyrus Revenue Laws } & 44\end{array}$


Papyrus Rylands IX

126

133

Papyrus Vienna

Papyrus Westcar

Papyrus Wilbour
129,134

125
Rosetta Stone 49

Sinuhe 30, 137, 148-149

Tale of Two Brothers $\quad 30,38,69,137$,

150-151

\section{Ancient Near Eastern texts}

ARM (Archives royales de Mari)

27.116,31-32

72

28.46,2-8

72

Ahiqar

$11,30,152-158$,

lines $26-27$

153

saying 13, col VII 94

154

saying 19 , col IV 126

154

162

\section{Greek texts}

Herodotus

Histories

II,41 



\section{Index of Modern Authors}

Ahituv, S. 77-78

Ahuis, F. 108

Albertz, R. 103, 108

Albright, W.F. 122

Alter, R. 56

Altmann, P. 92

Assmann, J. 115

Auboyer, J. 52

Aymard, A. 52

Azzoni, A. 159

Baden, J.S. 36, 56, 142, 144

Bakir A.E.-M.

Bauer, D. 83

Becking, B. 10, 158

Ben-Dor Evian, S. 68

Benz, B.C. 65-66, 73

Berman, J. 80

Berner, C. 18-19

Binder, S. 126-127

Bledsoe, S.A. 154

Blum, E. 17, 27, 37-38, 40-42, 57, 59, $103,110,118,140,142,147-148$

Boling, R.G. 62

Bonder, K. 98

Borchardt, L. 129

Bowman, A. 52

Braunstein-Silvestre, F. 123

Brettler, M.Z. 38, 42, 65

Brueggemann, W. 16

Brugsch, H. 155

Bulliet, R.W. 122

Burkard, G. 155-156

Burke, A. 68

Carr, D. M. 56-57, 59

Catastini, A. 40

Champault, D. 121-122

Clifford, R. J. 86

Coats, G.W. 36, 94, 143

Cogan, M. 63
Conczorowski, B. J. 75

Couroyer, B. 130

Crüsemann, F. 25, 40, 143

Cryer, F.H. 78-79

Davis, D. 79

Deuschle, M.A. 139

Dever, W.G. 67

Diebner, B. J. 40

Dietrich, W. 8, 17, 25, 38-40

Dillmann, A. 5

Döhling, J.-D. 12, 104, 109

Donner, H. 5, 83, 142

Ebach, J. 16, 19-20, 44, 103, 109, 113, 144, 159

Eco, U. 40

Ede, F. 28, 30, 39, 51-52, 58, 85, 87, 103 , $107,111,142$

Edgerton, W.F. 125-126

Eerdmans, B.D. 37

Epstein, H. 122

Erman, A. 124, 134

Faust, A. 67

Fieger, M. 14, 45, 56, 147-150

Finkelstein, I. 57, 68

Fischer, G. 38, 46

Fleming, D. 58-59, 65, 72

Fox, M.V. 117, 146, 150, 154

Frevel, C. 75, 159

Fried, L. S. 80

Gardiner, A.H. 125

Gauthier, H. 133

Gee, J. 162

Genung, M.C. 36, 39, 42, 45, 48-49, 85, 87, 98

Golka, F.W. 35

Gordon, C. H. 148

Granerød, G. 46 
Graupner, A. 43, 142

Greenstein, E.L. 149

Gressmann, H. 11

Grimal, N.-C. 149

Gross, W. 65

Gunkel, H. 5, 11, 13, 17-18, 48, 105, 141

Hamada, A. 131

Hamilton, V.P. 16, 20

Harris, J. R. 152-154

Heaton, E. W. 148

Heffelfinger, K. M. 92, 95-96

Hengstenberg, E. W. 56, 139

Hodel-Hoenes, S. 14, 45, 56, 147-150

Hoftijzer, J. 147

Holzinger, H. 5, 11, 18

Hoop, R. de 8, 109

Hossfeld, F. L. 64

Huddelston, J.R. 93

Humphreys, W.L. 86

Jacob, B. 12, 16, 36, 107

Jacobs, M.R. 99

Janot, F. 128

Janssen, J.M.A. 129

Jasmin, M. 121, 123

Jenson, P.P. 42

Jericke, D. 49

Joffe, A.H. 67

Johnson, B. 7

Jongeling, K. 147

Joosten, J. 111

Kaplony-Heckel, U. 25

Kebekus, N. 10, 12, 17, 37-40

Kim, H.C.P. $85-86$

King, J.R. 148

Kitchen, K.A. 56, 140

Koch, R. 148

Koenen, K. 148

Kooij, A. van der 46

Kosack, W. 131

Kratz, R.G. 5, 7, 14-15, 17, 19, 21, 26-29, 31-32, 39, 56, 58, 108-109, 141-142, $153,155,158,160$

Kruchten, M. 79
Lambert, J. 41

Lanckau, J. 8, 11-14, 104, 144

Lang, B. 77, 79, 84

Lange, A. 77, 79

Le Rider, G. 52

Leblanc, C. 135

Lee, J.A.L 46

Lefebvre, G. 129

Lepsius, R. 160

Levin, C. 6, 10-11, 13-14, 17-18, 37, 44, 51, 108-109, 150-151

Levin, Y. 41

Lichtheim, M. 152, 155

Lim, T.H. 46

Lindenberger, J. M. 152-154

Lisewski, K.D. 37

Lucas, A. 121

Lux, R. 8, 30, 42, 103, 145

Macchi, J.-D. 37-38

Magen, Y. 24

Mandolfo, C. 99

Matthews, V.H. 93

Meinhold, A. 15, 31, 43, 103, 148, 160

Menu, B. 125

Merwe, B. J. van der 7

Meyer, R. 83

Meyers, C.L. 59

Meyers, E.M. 60

Midant-Reynes, B. 123

Milstein, S. 65, 70

Monroe, L. 59

Montet, P. 121, 129, 131-132

Moran, W.L. 67

Müller-Wollermann, R. 150

Nash, D. 58

Naaman, N. 67

Naumann, T. 8, 20

Niditch, S. 81

Niehoff, M. 10

Nocquet, D. 126

Noth, M. 56

O'Brien, M.A. 94, 111

O’Connell, R. 65

Olson, D. T. 39 
Paap, C. 35,39

Parkinson, R. B. 148

Peust, C. 30,155

Pfeifer, G. 157

Pinker, A. 44

Pirenne, J. 120

Pirson, R. 56, 93-95, 104

Planhol, X. de 122-123

Pohlmann, K.-F. 32

Porten, B. 24, 152, 154, 158-159, 162

Posener, G. 120, 130

Posener-Krieger, P. 124

Préaux, C. 120

Prestel, P. 77

Pury, A. de 48, 57

Quack, J.F. 155

Quaegebeur, J. 134

Rad, G. von 18, 25, 36, 40, 116, 141, 144-145, 150-151

Rainey, A.F. 67

Ramond, S. 42

Ranke, H. 124

Rawlinson, G. 44

Rechenmacher, H. 82

Redford, D. B. $35,37,44,49,56,67$, $70,85,120,122,125-126,131-134$, $140,147,150,154,159$

Ringgren, H. 150

Röllig, W. 23

Römer, T. 15, 37-38, 40, 42, 44, 51, 56-57, $60,69,84-85,103,118,136,142,160$

Rosenthal, L.A. 103

Rudolf, W. 143

Ruppert, L. 11, 18, 36

Sauneron, S. 134-135

Schipper, B. U. 45, 50, 56-57, 68, 80, 82-83, 140, 142, 146-147, 151-152, 158-160, 162

Schlimm, M.R. 97

Schmid, K. 9, 11, 17, 38-39, 42-43, 45, 48, 56-57, 85, 103-104, 108-109, 115, 141, $143-145,149,159$

Schmidt, L. 9, 36, 42

Schmitt, H.-C. 11, 38, 51, 141

Schniedewind, W.M. 67, 68
Schorch, S. 77

Schorn, U. 18, 111

Schulman, A. R. 131-132

Schütze, A. 160

Schwartz, B. J. 36, 48

Schweizer, H. 11, 17

Seebass, H. 12, 15, 17, 31, 36-37, 48, 51, $56,109,143$

Sergi, O. 67

Shupak, N. 134-135, 157

Ska, J.L. 36, 38, 57

Skinner, J. 18, 150

Soggin, J.A. 40

Steinmann, F. 156

Sternberg, M. 56, 88-89

Sweeney, M. 65

Teeter, A. 57

Tengström, S. 8

Tilly, M. 46

Toorn, K. van der 45, 68, 158

Tov, E. 46

Tower-Hollis, S. 140, 150

Tur-Sinai, N.H. 78

Van Seters, J. 17

Vandier, J. 127, 155

Vergote, J. 40, 56, 119-122, 126-128, $130-133,140$

Vernus, P. 130, 132

Vittmann, G. 160, 162

Volokhine, Y. 130-131

Walle, B. van de 120

Warburton, D.A. 124

Weigl, M. 154

Weill, R. 125

Weimar, P. 10, 37, 46, 51

Weingart, K. 39-42, 57-58, 103, 118, 140, 147-148

Weinstein, J.M. 67

Weippert, M. 25-26, 30

Wellhausen, J. 6, 11, 13, 20, 36, 141

Wenham, G.J. 13, 20

Wénin, A. 56

Westermann, C. $11,17-18,41,51,85,87$

Wettengel, W. 150

White Crawford, S. 152 
Whybray, R.N. 36, 141

Wildung, D. 31

Wilson, L. 94

Willmes, B. 7

Wöhrle, J. 8, 103

Wolf, W. 120

Wright, G.E. 62
Yardeni, A. 24, 152, 154, 158

Yoyotte, J. 44

Zenger, E. 64

Zivie, A. 132 


\section{Index of Subjects}

Age of 110 years $129-130,147$

Agriculture 4, 12, 47, 66, 119, 121, 124

Ahiqar 11, 30, 152-158, 162

Alalakh 72

Amarna 61, 65-69, 72, 124

Apiru 25, 72

Arabia 44, 121-123

Asenath/Aseneth 55, 57, 71, 76, 83, 104, $132,147,148,157,159,162$

Assyria 11, 30-32, 59, 121, 133, 149, 152-153, 155

Babylon/Babylonian 11, 29, 31-32, 69, 76, 78, 82-84, 98-99, 118, 121, 133, 135, 149 , see also Neo-Babylonian period

Benjamin 8, 24, 26, 33, 36, 41-42, 44, $59,61,66,79,86-87,89-94,96,98$, $100-101,110-112$

Bronze age 61, 66-68

Camel 121-123

Canaan 3, 13, 15, 20-21, 30, 51-52, 55-56, 58-62, 64, 66-68, 70-73, 75, 80, 86-88, 90-92, 95, 98, 101, 124, 126, 159

Capitalism 3, 37, 51-52

Court tales 30, 152

Covenant 89, 94, 115

Daniel 30-32, 57-58, 83, 103, 115, 117, $135,152,159$

Deuteronomistic texts 3, 26, 44, 78, 84, 103-104, 114-115, 143, 145

Diaspora novella $2-3,5,21,23,31-32,37$, 43-46, 52, 56-58, 85, 100, 103-104, 117, $136,140,160$

Diaspora 3, 15-16, 20-21, 28-29, 31-32, 43-46, 52-53, 57-58, 71-73, 84, 86, 98-101, 103, 117, 132, 136, 152-153, 159-160, see also diaspora novella, Elephantine

Divination 42, 75-80, 84, 92-93, 149
Documentary Hypothesis, see Yahwistic texts, Elohistic texts, Priestly texts, Deuteronomistic texts

Dream 3-4, 6, 10-15, 26, 36, 44, 47-50, 56, 69-71, 75, 77-79, 81, 86-87, 92, 94-95, 97-98, 101, 104-113, 117, 134-135, 137, 140, 142-146, 155-158

Elephantine 23, 28-31, 33, 45-47, 50, 52, $56-57,84,104,126,140,152-153,155$, $157-162$, see also diaspora

Elohim 35, 43, 47, 50, 83

Elohistic texts 2, 36, 43, 142-143

Embalming 4, 42, 127-128, 130, 147

Ephraim 1, 24, 26, 42, 55, 59-60, 62-63, $71,76,81,86,95$

Esther 15, 30-32, 43-44, 57, 103, 152, 160

Famine 4, 13, 31-32, 49-51, 69-71, 86-87, 91-92, 95-96, 98, 101, 107, $124,155-158$

Food 41, 51, 87-89, 92, 100-101, 124, 156

Goshen 44, 80, 84, 157

Greco-Roman period, see Hellenistic period

Hartummim, see magicians

Hellenistic period 1-4, 23, 28-31, 35-53, $57,79,120-123,125-126,128,132-133$, $135-136,152,156$

Hexateuch 3, 6, 8-9, 36, 38, 42, 55-57, 59-60, 85, 103, 141-143

Hunger, see famine

Intermarriages $3,44,53,71,75-77,104$, $148,159,162$

Iron age $48,61,67-68,121$

Jeroboam 25-27, 63-64, 67-68, 73 
Letter of Aristeas 28, 46

Levantine 44, 52, 59, 61, 65, 68, 121, 123 , 147,162

LXX, see Septuagint

Magicians 129, 134-135

Manasseh 24, 26, 42, 55, 59-60, 62, 71, 76, $78,81,86,95$

Mari 72

Masoretic text 5, 52, 62, 64, 78-79, 98

Mixed marriages, see intermarriages

Nadin 153, 155

Naming, see onomasticon

Neo-Babylonian period 4, 23, 29-30, 147

Onomasticon 3, 7, 16, 23-25, 42, 53, 70, 75, 81-84, 86, 95, 105 130-133, 136, $146-147,157,160,162$

Patriarchs $1-3,5,9-10,18-19,25,27$, 29-30, 32, 35-38, 42-43, 56, 81, 142

Pentateuch 1-2, 5, 29, 38, 46, 51-52, 56, $60,85,93,136,139,142$

Persian period $1,3-4,23,28-32,35-53$, $57,83,118,121-123,136,147,152,155$, 157-163

Post-exilic 3, 24, 32, 40, 46, 57, 60, 75, 84, 115

Potiphera 70, 76, 83, 140, 147-148, 157

Priestly texts $2,19,36,40,42-43,48$, 56-57, 78, 85, 103, 108, 117, 142-143

Priesthood (Egyptian), 50-51, 71, 76, 80, 104, 125-127, 147-148, 155, 157-158
Prophets 40, 46, 59-60, 80, 84, 86

Ptolemaic period, see Hellenistic period

Ramesses 120, 122, 125, 130, 157

Reconciliation 3, 38-39, 41, 46, 48, 57, 85-101, 110, 112

Rehoboam 25-27

Reuben 11, 24, 36, 38-39, 82, 89, 91, 111

Samaria 3, 24, 26-31, 33, 45-46

Septuagint 44-46, 47, 52, 64, 76-78, 111

Seven years $8,12,50,70,107,152$, 155-158

Shasu 25

Sheol 90-91, 100

Shishak 26, 67-68

Shoshenq, see Shishak

Simeon 24, 27, 75, 82, 89-90, 100, 112

Slavery 37, 51-52, 63, 80, 88, 92-93, 97, $101,111-113,119-120,131,153,157$

Solomon 25-26, 40, 63-64, 67-68, 75-76, 117

Tax 52, 63-64, 71, 125-126

Tobit 30-32, 152, 154

Ugarit 48,72

Wisdom 1, 4, 35, 70, 79, 94, 114-117, 141, $143,145-146,150-154,158$

Xenophobia 31, 44

Yahwistic texts 2, 17, 36, 46, 56, 142

Yhwh 7, 9-10, 23, 28-29, 33, 35, 37, 43, $47,76,78,83-84,109,117,158$ 